Universidade de São Paulo

Faculdade de Arquitetura e Urbanismo

Programa de Pós-Graduação em Design

Rayza Mucunã Paiva

\title{
Os Kaxinawá do Acre e os livros da Coleção Autoria Indígena: uma análise em design editorial
}



Rayza Mucunã Paiva

Os Kaxinawá do Acre e os livros da Coleção Autoria Indígena: uma análise em design editorial

Dissertação apresentada ao Programa de Pós-Graduação em Design da Faculdade de Arquitetura e Urbanismo da Universidade de São Paulo para obtenção do título de Mestre em Design.

Área de concentração:

Design

Linha de pesquisa:

Processos e Linguagens

Orientação:

Prof. Dra. Cyntia Santos Malaguti de Sousa

São Paulo

2020

EXEMPLAR REVISADO E ALTERADO EM RELAÇÃO À VERSÃO ORIGINAL, SOB RESPONSABILIDADE DA AUTORA E ANUÊNCIA DA ORIENTADORA.

A versão original, em formato digital, ficará arquivada na Biblioteca da Faculdade.

São Paulo, 13 de julho de 2020. 
Esta dissertação foi projetada e diagramada por Rayza Mucunã Paiva com as fontes Helvetica, criada por Max Miedinger e Eduard Hoffman, e Brasilica, criada por Rafael Dietzsch. Estas fontes foram selecionadas por possibilitarem a aplicação de diacríticos específicos utilizados em línguas indígenas brasilieiras.

A reprodução e divulgação total ou parcial deste trabalho, por qualquer meio convencional ou eletrônico, para fins exclusivos de estudo e pesquisa, é autorizada, desde que citada a fonte.

Esta pesquisa contou com o auxílio do Programa de Demanda Social Coordenação de Aperfeiçoamento de Pessoal de Nível Superior

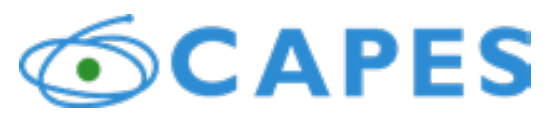

Catalogação na Publicação I Serviço Técnico de Biblioteca Faculdade de Arquitetura e Urbanismo da Universidade de São Paulo

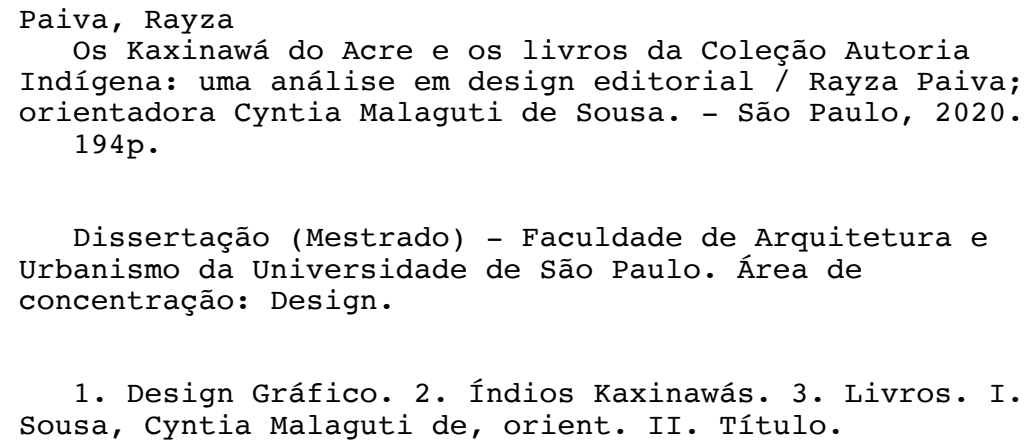

1. Design Gráfico. 2. Índios Kaxinawás. 3. Livros. I. Sousa, Cyntia Malaguti de, orient. II. Título. 
Rayza Mucunã Paiva

\title{
Os Kaxinawá do Acre e os livros da Coleção Autoria Indígena: uma análise em design editorial
}

\author{
Dissertação apresentada ao Programa de \\ Pós-Graduação em Design da Faculdade \\ de Arquitetura e Urbanismo da Universi- \\ dade de São Paulo para obtenção do título \\ de Mestre em Design.
}

Aprovado em: 14/05/2020

\section{Banca Examinadora}

Profa. Dra. Cyntia Malaguti de Sousa (Presidente)

Instituição: Universidade de São Paulo

Profa. Dra. Andréa de Souza Almeida

Instituição: Universidade Presbiteriana Mackenzie

Profa. Dra. Eliete da Silva Pereira

Instituição: Universidade do Estado de Minas Gerais

Julgamento: Aprovada com recomendação para publicação. 



\section{Agradecimentos}

À toda minha família, pelo amor incondicional.

Aos meus pais, pelo apoio de sempre. Obrigada por serem meus orientadores, revisores e professores desde quando me entendo por gente.

À minha irmã, meu irmão, e aos amigos que me ouviram, acolheram e me ajudaram no difícil processo de mudança para São Paulo. Em vocês pude ter um lar nesta cidade intimidadora. Obrigada por compartilhar comigo a alegria e o carinho que tem de sobra.

À Letícia Pedruzzi Fonseca, que me orientou na iniciação científica e no trabalho de conclusão da graduação, pela ajuda na produção do pré-projeto de pesquisa com o qual ingressei no mestrado. Obrigada por ter participado e apoiado minhas aventuras nas pesquisas acadêmicas que fiz até agora.

À querida Cyntia Malaguti, por ter abraçado o projeto desde o início. Pela orientação, discussões e contribuições indispensáveis à esta dissertação e, acima de tudo, pela paciência, alegria e delicadeza que lhe são características e que tornaram o processo da pesquisa, muitas vezes estressante, mais leve e bem-humorado.

Às professoras Eliete Pereira e Priscila Lena Farias, pelas valiosas contribuições feitas na banca de qualificação, que permitiram o aperfeiçoamento deste trabalho.

À Coordenação de Aperfeiçoamento de Pessoal de Nível Superior, por apoiar financeiramente o desenvolvimento desta pesquisa desde 2019.

À Comissão Pró-índio do Acre, pelo trabalho pioneiro na educação indígena acreana e por ter aberto as portas de seu acervo e de sua sede para a realização desta pesquisa.

À equipe da Comissão Pró-índio do Acre, pela hospitalidade com a qual me receberam durante nossa convivência no desenvolvimento da pesquisa de campo, sempre dispostos a responder minhas incessantes perguntas.

Em especial à Vera Olinda Sena, por ter me apresentado o acervo do Centro de Documentação e Pesquisa Indígena e pela disponibilidade e paciência com a qual me forneceu informações e dados durante todo o processo de desenvolvimento desta dissertação, e a Paula Lima e Sara Cruz pela ajuda, conversas e acolhimento.

Aos entrevistados, que gentilmente disponibilizaram seu tempo para responder minhas perguntas, compartilhando informações valiosas e um pouco de suas histórias de vida.

Aos professores e autores indígenas dos livros da Coleção Autoria Indígena, pelo incrível e necessário trabalho que desenvolveram e ainda desenvolvem. Obrigada por compartilhar com o mundo suas histórias, seus conhecimentos e culturas. 



\section{Todas as estrelas que existem no universo são fêmeas. E todas elas olham o Acre.}

Jaime Lullu Manchineri, 1998 



\section{Resumo}

PAIVA, R. M. Os Kaxinawá do Acre e os livros da Coleção Autoria Indígena: uma análise em design editorial. 194 p. Dissertação (Mestrado) - Faculdade de Arquitetura e Urbanismo, Universidade de São Paulo, 2020.

No propósito de contribuir para a formulação e desenvolvimento de questões pertinentes à configuração de impressos voltados para difundir, adequada e sensivelmente, culturas ancestrais, a presente pesquisa se propõe a analisar detalhadamente o componente gráfico dos livros de autores da etnia Kaxinawá que integram a "Coleção Autoria Indígena", publicada pela Comissão Pró Índio do Acre, CPI-AC, organização da sociedade civil que atua no campo dos direitos indígenas. Com publicações para as etnias Yawanawa, Katukina, Shawãdawa, Poyanawa, Yaminawa, Kaxinawá, Ashaninka, Manchineri e Apurinã, todas habitantes das cabeceiras dos rios do Acre, a "Coleção Autoria Indígena" resulta de um pioneiro projeto de formação de professores indígenas, que se desenvolveu durante 25 anos, de 1985 a 2008. Através do levantamento de dados sobre as publicações, realizado em campo na sede da CPI-AC em Rio Branco; de entrevistas com os membros da entidade; e de revisão bibliográfica a respeito do contexto histórico das etnias indígenas acreanas, assim como do projeto "Uma experiência de autoria dos índios do Acre"; são apresentados e analisados os métodos editoriais e as características gráficas dos livros da Coleção. Em seguida, mediante o estudo de aspectos fundamentais da cosmologia e da cultura visual e material Kaxinawá; associado à análise e mapeamento dos elementos gráficos compositivos dos livros produzidos exclusivamente por professores dessa etnia, foi possível compreender a relação entre a configuração gráfica de tais impressos e as manifestações visuais tradicionais daquele povo.

Palavras-chave: Autoria indígena; Design gráfico; Comissão Pró-índio do Acre; Huni Kuĩ; Análise gráfica. 



\section{Abstract}

PAIVA, R. M.. The Kaxinawá of Acre and the books of the Coleção Autoria Indígena: an analysis in editorial design. 194 p. Thesis (Masters) - Faculdade de Arquitetura e Urbanismo, Universidade de São Paulo, 2020.

In order to contribute to the formulation and development of questions pertinent to the configuration of printed materials aimed at spreading, appropriately and sensibly, ancestral cultures, this research proposes to analyze in detail the graphic component of the books of authors of the Kaxinawa ethnic group that integrate the "Coleção Autoria Indígena", published by Comissão Pró Índio do Acre, CPI-Acre (CPI-AC) an ONG that works in the field of indigenous rights. With publications for the Yawanawa, Katukina, Shawãdawa, Poyanawa, Yaminawa, Kaxinawá, Ashaninka, Manchineri and Apurinã ethnicities, all inhabitants of the headwaters of Amazon's rivers, the "Coleção Autoria Indígena" is the result of a pioneering project for the training of indigenous teachers, which was developed for 25 years, from 1985 to 2008. By collecting data about the publications, carried out in the field at the CPI-AC headquarters in Rio Branco; interviews with members of the entity; and bibliographic review about the historical context of indigenous Acre ethnicities, as well as the project "Uma experiência de autoria dos indios do Acre"; editorial methods and graphic characteristics of the books in the Collection are presented and analyzed. Then, through the study of fundamental aspects of cosmology and visual and material culture Kaxinawá; associated with the analysis and mapping of the compositional graphic elements of books produced exclusively by teachers of that ethnicity, it was possible to understand the relationship between the graphic configuration of such printed matter and the traditional visual manifestations of the Kaxinawá culture.

Keywords: Indian authorship; Graphic design; Comissão Pró-índio do Acre; Huni Kuĩ; Graphic analysis. 



\title{
Sumário
}

\author{
17 ..... Introdução \\ Capitulo 1. \\ 21 ..... A pesquisa \\ 22 .... 1.1. Justificativa \\ 24 ..... 1.2. Objetivos \\ 24 .... 1.3. Métodos \\ 28 ..... 1.4. Delimitações \\ Capítulo 2.
}

29 .... O movimento indígena no acre, a cpi-ac e a autoria indígena

29 .... 2.1. Uma breve história dos índios do Acre

32 ..... 2.2. História socioeconômica dos kaxinawá no Acre

39 .... 2.3. A história da CPI-AC

42 .... 2.4. Os cursos de formação de professores indígenas

50 .... 2.5. Os métodos editoriais da CPI-AC

61 ..... 2.6. O letramento e a autoria indígena

Capítulo 3.

77 ..... A coleção autoria indígena

83 .... 3.1. De 1983 a 1989: aprender fazendo

91 .... 3.2. De 1990 a 1999: a gráfica Kene Hiwe

111 ..... 3.3. De 2000 a 2008: diversificar e aprimorar

125 ..... 3.4. "O mundo indígena é bem colorido"

Capitulo 4.

131 ..... Os livros kaxinawá da coleção autoria indígena

131 .... 4.1. Cultura material e imaterial kaxinawá

138 ..... 4.2. Kene kuĩ: o desenho verdadeiro

146 ..... 4.3. Autores e publicações kaxinawá da coleção autoria indígena

164 ..... 4.4. Mapeamento dos elementos gráficos

179 ..... 4.5. Reflexões finais

187 ..... Considerações finais

189 ..... Referências 



\section{Introdução}

Como todo grupo humano, os povos indígenas têm culturas que resultam da história de relações que se dão entre os próprios homens e entre estes e o meio ambiente; uma história que, no seu caso, foi (e continua sendo) drasticamente alterada pela realidade da colonização. (PIB, ISA, s/ d.)

Os descendentes dos primeiros habitantes do território brasileiro organizam-se, atualmente, em cerca de 305 povos (remanescentes dos estimados mais de 1.000 existentes na chegada dos colonizadores ao Brasil pré-colonial), falantes de mais de 260 línguas distintas ${ }^{1}$. A denominação genérica "índio" é uma categoria jurídica que agrupa, legalmente, os direitos voltados a essa população, reconhecidos pelo Estado brasileiro a partir da Constituição Nacional de 1988 (GALLOIS et al., 2016).

Os próprios "índios", no entanto, recusam essa nomenclatura generalista, atribuindo à palavra uma caracterização simplificada e folclórica, cunhada pelo colonizador de maneira diminuidora. O autor Daniel Munduruku, indígena da etnia Munduruku, descreveu a questão da seguinte forma:

No nosso imaginário existe um índio que foi construído, paulatinamente, ao longo da nossa história. A palavra índio faz parte dessa construção, inclusive no contexto de tomada das terras pelos portugueses. Por isso preferimos o termo 'indígena', que se refere a quem é natural, originário de uma terra. No Brasil não existem índios, existem indígenas. (MUNDURUKU, 2018)

Segundo as pesquisadoras Dominique Tilkin Gallois, Tatiane Klein e Talita Lazarin Dal'Bo (GALLOIS et al., 2016), apesar de seu caráter genérico, que, na maioria das vezes, mais "nubla" do que esclarece sobre a diversidade dos povos indígenas no Brasil, o termo "índio" é a classificação que permite a união necessária entre as etnias existentes para possibilitar o reconhecimento de direitos fundamentais. Ainda segundo as autoras, o reconhecimento de tais povos perante dispositivos constitucionais ocorre a parir de sua tipificação em categorias generalizantes tais como "índios" ou "minorias" (Ibid., p. 33). A Constituição brasileira de 1988 trouxe avanços indispensáveis para a manutenção cultural e territorial das etnias indígenas existentes no país, tornando-se um marco histórico, nesse sentido.

Trata-se de direitos marcados por pelo menos duas inovações conceituais importantes em relação a Constituições anteriores e ao chamado Estatuto do Índio. A primeira inovação é o abandono de uma perspectiva assimilacionista, que entendia os índios como categoria social transitória, fadada ao desaparecimento. A segunda é que os direitos dos índios sobre suas terras são

1 Segundo dados da Secretaria de Educação Continuada, Alfabetização, Diversidade e Inclusão (Secadi), o Brasil possui uma população de 817 mil indígenas, representando 305 povos e 274 línguas (MEC, 2016). 
definidos enquanto direitos originários, isto é, anterior à criação do próprio Estado. Isto decorre do reconhecimento do fato histórico de que os índios foram os primeiros ocupantes do Brasil. (PIB, ISA, s/ d.)

A contradição entre a necessidade de generalização para obtenção de regulamentações constitucionais que garantem, exatamente, o direito à diferença, é comparável à distância existente entre a qualidade da legislação existente e a imensa dificuldade em sua correta aplicação (GALLOIS, et al., 2016, p. 33).

Ainda assim, a Constituição de 1988 e a criação de escolas decorrentes da mesma fez com que a escolarização e o letramento indígena crescessem exponencialmente. Em estudo publicado em $2009^{2}$ pelo Ministério da Educação, análises estatísticas demonstram que:

De modo geral, o crescimento da Educação Indígena, ao longo dos últimos dez anos ${ }^{3}$, é muito expressivo. Nesse período, tomando como base os dados do Censo Escolar Indígena de 1999, o número de escolas quase duplicou, passando de 1.392 para 2.698 (em 2008), um acréscimo de $93,8 \%$. A partir de 2004 , o número de matrículas acompanha o crescimento paulatino dos estabelecimentos (...) ( MEC, INEP, 2009, p. 10)

Diretamente associado a este desenvolvimento está a produção de material impresso de autoria indígena, para utilização nas escolas, dentro e fora das comunidades, como apoio ao processo pedagógico de formação de professores e alunos (SOUZA, 2006).

Outra feliz consequência da disseminação do letramento indígena é a popularização da literatura de autoria indígena. Neste momento é importante relevar que a "escrita" de determinado povo pode se manifestar de variadas formas - para além da escrita alfabética e verbal a que tradicionalmente nos referimos-, através de grafismos, tecelagens em tecido, entrelaçamento de fibras naturais em cestarias, dentre outras. $O$ presente trabalho pretende focar-se na escrita propriamente alfabética - que registra em papel a fala e o som - e que, apesar de introduzida nas comunidades indígenas a partir da colonização européia desde o século XVI, apenas nos últimos trinta anos teve seu verdadeiro florescer (SOUZA, 2006).

A literatura indígena contemporânea é um lugar utópico (de sobrevivência), uma variante do épico tecido pela oralidade; um lugar de confluência de vozes silenciadas e exiladas (escritas) ao longo dos mais de 500 anos de colonização. Enraizada nas origens, a literatura indígena contemporânea vem se preservando na auto-história de seus autores e autoras e na recepção de um público-leitor diferenciado, isto é, uma minoria que semeia outras leituras possíveis no universo de poemas e prosas autóctones. (GRAÚNA, 2013, p. 15)

Graça Graúna, pesquisadora e escritora indígena da etnia Potiguara, em livro sobre a literatura indígena contemporânea, traça um pequeno histórico do desenvolvimento da modalidade. Segundo a autora, a literatura indígena inicia seu percurso a partir dos anos 1970 (Ibid., p. 74), com o surgimento

2 Infelizmente faltam fontes mais recentes, assim como novos estudos, tendo em vista que o último censo escolar indígena foi realizado em 2008.

3 De 1999, data do primeiro censo escolar indígena, a 2009 com a publicação do artigo a partir do senso de 2008. 
de organizações e instituições não-governamentais que agiam em defesa dos direitos indígenas. $\mathrm{O}$ movimento segue um trajeto conturbado, marcado pelo preconceito e pela falta de diálogo como governo brasileiro, de forma geral, durante as décadas de 1980 e 1990, chegando aos anos 2000 enquanto uma forma de resistência e manifestação cultural (Ibid., p. 77-80).

As primeiras iniciativas na década de 1970 foram importantes não só por introduzir a produção de publicações associadas à educação indígena diferenciada (que, vale lembrar, ainda não era garantida por lei), mas também por gerar uma categoria específica de publicações: os livros subsidiados por órgãos institucionais que, em conjunto com aqueles lançados por editoras privadas nas décadas subsequentes, formam hoje um movimento não só literário, como também político (GRAÚNA, 2013, p. 86).

Inserida nesse contexto, a Comissão Pró-índio do Acre (CPI-AC) foi fundada em 1979, fruto da atuação de antropólogos e educadores indigenistas envolvidos na luta pela demarcação de territórios indígenas no estado do Acre.

Em 1983 a instituição dá início a um abrangente projeto de educação, voltado para formação de professores indígenas num processo educativo inovador de intercâmbio cultural. Este projeto tomou os professores em formação e suas comunidades como sujeitos atuantes de forma direta na concepção do currículo a ser adotado nas recém-criadas Escolas da Floresta (como eram então chamadas as escolas das comunidades indígenas acreanas).

$\mathrm{Na}$ realização do primeiro Curso de Formação de Professores Indígenas (a partir de quando os cursos passaram a acontecer anualmente) percebeu-se a necessidade de desenvolvimento de materiais didáticos próprios e específicos para serem utilizados pelos professores em sala de aula. Assim começou o projeto Uma experiência de autoria dos índios do Acre, iniciativa voltada para o desenvolvimento de tais materiais nos momentos de formação promovidos pela instituição.

Os livros eram concebidos em processos editoriais colaborativos, baseados na compreensão de que a educação diferenciada para comunidades indígenas deve partir dos conhecimentos específicos de cada cultura, e ser apresentado como tal (MONTE, 1996).

Idealizado pela antropóloga Nietta Lindenberg Monte, o projeto se tornou referência por seu pioneirismo e originalidade no campo da autoria indígena, ganhando destaque nacional e internacional por meio das publicações realizadas (Idem, 2003).

O projeto desenrolou-se por mais de 25 anos (entre 1983 e 2008) e resultou em 92 publicações. Os livros compõem a Coleção Autoria Indígena, que inclui, além de cartilhas de alfabetização, matemática e pós-alfabetização (em português e nas línguas indígenas correntes no Acre faladas pelas etnias: yawanawa, katukina, shawãdawa, poyanawa, yaminawa, kaxinawá, ashaninka, manchineri e apurinã), narrativas míticas e de cantos; livros de história e de geografia; registros sobre a cultura tradicional; planos de gestão ambiental e territorial de terras indígenas, entre outros. A maior parte dos livros é de autoria coletiva, composta por professores de etnias variadas, mas há também aqueles produzidos por professores de uma mesma etnia e, em menor número, publicações desenvolvidas por apenas um autor.

Atualmente, os livros encontram-se preservados em acervo no Centro de Documentação e Pesquisa Indígena (CDPI), localizado na sede da CPI-AC em Rio Branco. No final de 2016 a pesquisadora visitou o acervo pela primeira vez, como parte de uma breve visita guiada à sede da instituição. Deste contato nasceu o interesse pelas publicações produzidas pela Comissão, catalogadas e armazenadas no CDPI. 
Assim, a presente pesquisa começou a tomar forma. Um longo caminho foi percorrido desde então, para que se pudesse chegar a um recorte analítico bem definido, dentre as diversas possibilidades de pesquisa despertadas pelos livros da Coleção.

Após as várias disciplinas cursadas e a realização de estudos preliminares sobre o acervo, decidiu-se por um direcionamento que considera tanto as características gerais dos livros que compõem a Coleção Autoria Indígena, quanto a análise mais aprofundada e específica dos livros escritos exclusivamente por autores da etnia Kaxinawá. Tais decisões são pormenorizadas no primeiro capítulo desta dissertação, que abrange seus objetivos, métodos e justificativa.

Já o segundo capítulo explora o contexto histórico, político e social que precede a realização do projeto de educação indígena da CPI-AC, e no qual o mesmo se insere. Atenção especial é dada aos percursos da etnia Kaxinawá, assim como da própria CPI-AC e dos cursos de formação indígena. Intenciona-se compreender como aspectos específicos do contexto se refletem no desenvolvimento dos métodos editoriais da instituição, assim como no conceito de autoria indígena aplicado pela mesma. Este levantamento é um importante aporte para que se possa compreender a história dos livros da Coleção, apresentada no capítulo seguinte.

O terceiro capítulo descreve em detalhes a produção das várias publicações da Coleção Autoria Indígena de acordo com os anos de desenvolvimento do projeto "Uma experiência de Autoria dos Índios do Acre". Dados gerais, quantitativos e qualitativos, sobre o acervo são apresentados, assim como as principais características gráficas e aspectos editoriais dos livros publicados.

O quarto e último capítulo diz respeito ao exame dos livros especificamente escritos por autores kaxinawá. A partir de um levantamento sobre a cultura, a cosmologia e as manifestações visuais e materiais características dessa etnia, os elementos gráficos que compõem os projetos dos livros são mapeados e analisados, sobretudo as ilustrações. A intenção é compreender como as manifestações culturais tradicionais do povo Kaxinawá são representadas graficamente nos livros.

Por fim, através da pesquisa apresentada, pretende-se contribuir para a expansão de conhecimentos relacionados ao design editorial voltado aos livros de autoria indígena, ampliando a bibliografia destinada a este tema e realçando a importância, por um lado, do importante trabalho executado pela CPI-AC e pelos autores indígenas e, por outro, da elaboração de pesquisas que se preocupem com o posicionamento crítico e ético do design enquanto área de conhecimento. 


\section{A pesquisa}

A presente pesquisa foi concebida no campo do Design Gráfico, tendo como objeto de investigação as publicações que integram a Coleção Autoria Indígena, publicada pela Comissão Pró-índio do Acre (CPI-AC) ${ }^{1}$, no período de 1983 a 2008. Elaborados no âmbito do projeto "Uma Experiência de Autoria dos Índios do Acre", os livros da Coleção foram concebidos em programas de formação de professores indígenas promovidos por aquela Comissão.

O programa de qualificação de professores indígenas da CPI-AC é reconhecido por especialistas como um processo educativo inovador de intercâmbio cultural, pioneiro no desenvolvimento de um currículo didático específico para a educação indígena, bem como na produção de material didático próprio de autoria indígena.

No propósito de contribuir para a formulação e desenvolvimento de reflexões pertinentes à configuração de impressos voltados para difundir, apropriada e sensivelmente, culturas autóctones ancestrais, a presente pesquisa se propôs a investigar o seguinte:

a) o conceito de autoria indígena;

b) os métodos editoriais aplicados pela CPI-AC;

c) o processo de composição; e,

d) a configuração gráfica das publicações da Coleção.

Tomou-se como objeto de investigação, especificamente, os projetos gráficos e as ilustrações que compõem os livros didáticos de autores kaxinawá, etnia que se encontra distribuída nas cabeceiras dos rios Tarauacá, Jordão, Breu, Muru, Envira, Humaitá e Purus, que cortam transversalmente o território do Acre.

A definição desse recorte, necessário tendo em vista o grande número de livros que compõem a Coleção ${ }^{2}$, adveio das contribuições e considerações feitas durante a banca de qualificação, assim como de uma primeira experiência de análise gráfica ${ }^{3}$, através da qual comprovou-se a enorme importância das ilustrações, tanto na configuração visual e gráfica dos volumes, quanto como dimensão fundamental da autoria indígena dos livros.

As professoras doutoras Eliete Pereira e Priscila Farias, componentes da banca, ressaltaram a importância de que o levantamento de dados da pesquisa abrangesse a compreensão das culturas específicas dos autores e ilustradores dos livros em questão, para que se pudesse empreender uma análise mais profunda e adequada das ilustrações e grafismos que compõem os projetos dos livros. Com isso em mente, decidiu-se pela seleção

1 Doravante referida pelo acrônimo CPI-AC.

292 livros, exatamente, conforme é descrito no Capítulo 3 desta dissertação.

3 A análise gráfica das capas dos livros de leitura (um dos conjuntos que compõem a categorização temática dos livros da Coleção, detalhada no Capítulo 3 desta dissertação) foi desenvolvida durante a disciplina Memória Gráfica e Cultura Material, ministrada pelos professores Marcos da Costa Braga e Priscila Farias no segundo semestre de 2018. O artigo que apresenta os resultados foi publicado nos anais do $9^{\circ}$ Congresso Internacional de Design da Informação (PAIVA, SOUSA, 2019). 
de livros de autores Kaxinawá, por se tratar de uma etnia a respeito da qual existe considerável volume de material bibliográfico disponível, em destaque o fascinante trabalho de Lagrou (1991, 2007), ampla pesquisa a respeito da arte e cosmologia dos Kaxinawá amazônicos.

Sendo assim, o presente capítulo contextualiza a pesquisa realizada, explicita as motivações para sua realização, apresenta os objetivos a serem alcançados e discorre sobre os métodos de levantamento e tratamento de dados utilizados durante seu planejamento e execução.

\subsection{Justificativa}

Intenta-se com a presente pesquisa contribuir para a ampliação da bibliografia existente a respeito do design editorial de conteúdos produzidos por e voltados para comunidades indígenas, tendo em vista que, a despeito de sua relevância para a sociedade brasileira, a cultura indígena se caracteriza como um patrimônio intelectual por vezes invisível na produção acadêmica voltada para a área de Design Gráfico Editorial.

Sem embargo, a demanda por projetos gráficos no contexto das publicações indígenas, principalmente aquelas que fazem parte de processos de formação educativa nas comunidades, tende a crescer exponencialmente, dado o reconhecimento da importância de tais iniciativas. A expectativa é de que em um futuro próximo, as grafias indígenas nacionais se tornem importante Linha de Pesquisa para pesquisadores do Design Gráfico Editorial.

Segundo dados do Ministério da Educação - MEC, a educação indígena é o segmento educacional que mais cresce no país, apresentando um aumento de 48,7\% entre 2003 e 2014 (SILVA, SILVA, 2014); dessa forma, cresce também a demanda por projetos editoriais que possam atender este segmento.

Diniz (2007), ao pesquisar o desenvolvimento de fontes tipográficas voltadas para línguas indígenas, afirma que "o design é capaz de habitar o terreno muito fértil entre as demandas sociais e as nossas produções em tipografia" (Ibid., p. 45). Esta pesquisa propõe a expansão desse pensamento de forma a incluir todo o planejamento gráfico do impresso, sua mancha gráfica, diagramação, ilustrações etc. Para tanto, é de suma importância compreender os processos e atores que dão forma a este planejamento, assim como a visualidade do objeto final.

O "terreno fértil" de conteúdos e demandas editoriais advindos de (e voltados para) comunidades indígenas, é repleto de desafios capazes de enriquecer significativamente a construção crítica e científica das discussões em design, pois remetem diretamente à interdisciplinaridade essencial do design enquanto campo de atuação, e que é indispensável à compreensão da complexa relação entre design, cultura e sociedade. Relação esta que, na pesquisa em design, "é raramente confrontada. Ao se deixar de lado essa reflexão, tem-se um afunilamento de horizontes e a degradação da consciência projetual" (BONSIEPE, 2007, p. 38, tradução livre).

$\mathrm{E}$, em última análise, posicionando o design como fator integrante e determinante das metodologias aplicadas na confecção desse tipo de impresso, como agente de reflexão, questionamento e definição de diretrizes e premissas, ao invés de apenas o último elo na cadeia projetual, responsável tão somente pela construção técnica dos produtos.

O projeto de formação de professores indígenas elaborado e desenvolvido pela CPI-AC a partir de 1983 foi pioneiro no país. A concepção da proposta didática das, então embrionárias, Escolas da Floresta, baseada na autoria indígena e fundamentalmente atrelada à produção textual e editorial dos livros didáticos específicos, influenciou uma série de projetos e políticas públicas 


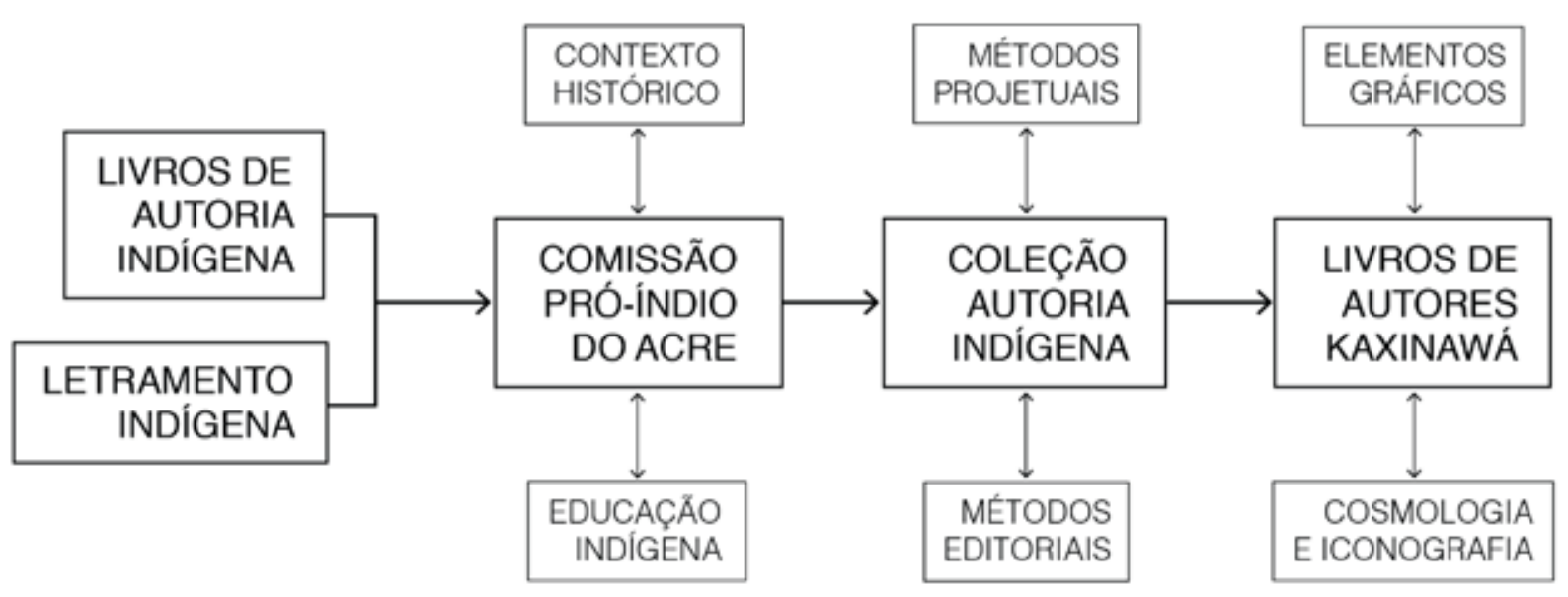

que viriam a existir, em especial após a Constituição de 1988 - por exemplo, o primeiro Referencial Curricular para Escolas Indígenas, publicado em 1998 pelo Ministério da Educação (MONTE, SENA, et. al., 2001).

Ainda segundo Graça Graúna (2013), especialista em literatura indígena contemporânea, o projeto da CPI-AC foi um dos responsáveis pela disseminação da prática literária indígena por outros estados brasileiros, especialmente no que diz respeito aos projetos subsidiados por organizações não governamentais.

Por sua importância e impacto, um cabedal de pesquisas e estudos foram feitas a respeito dos múltiplos aspectos conceituais e práticos da proposta de educação indígena da CPI-AC. Contudo, não existem pesquisas abordando, especificamente, os meios de construção editorial e gráfica dos livros didáticos produzidos pelos professores indígenas, e sua relação com os métodos editoriais aplicados pela instituição, assim como com o próprio conceito da autoria indígena e suas especificidades.

Desse modo, o levantamento de tais meios e métodos de configuração (editorial e gráfica) das publicações, proposto por esta pesquisa, configura-se como uma fonte de insumos para pesquisas futuras que também se utilizem dos livros da Coleção como ponto de partida.

Para além de catalogar e levantar dados sobre a feitura dos livros da Coleção, a análise proposta nesta pesquisa se propõe a compreender as relações construídas entre a configuração gráfica dos impressos e as manifestações gráficas tradicionais das etnias indígenas de seus autores.

Para que se pudesse desenvolver tal investigação em tempo hábil, fez-se necessário selecionar uma das etnias atendidas pela instituição. A riqueza do material bibliográfico existente sobre a cosmologia e cultura Kaxinawá / Huni Kuĩ facilitou a decisão de analisar os livros escritos por e voltados para essa etnia, tendo em vista que a assimilação das manifestações estéticas tradicionalmente indígenas é demasiadamente superficial quando não combinada com a compreensão de seu papel social e cultural dentro de determinada etnia.

Além disso, os Kaxinawá destacam-se como responsáveis pela apresentação da demanda por professores indígenas que dá origem ao projeto, sendo uma das etnias presentes desde o primeiro curso realizado, e, também, a etnia que mais participou da produção de livros no geral. De acordo com dados levantados nessa pesquisa, autores kaxinawá estão presentes em $55,8 \%$ dos livros da Coleção ${ }^{4}$.

4 Maiores comentários sobre outros dados quantitativos da Coleção são feitos no Capítulo 3 desta dissertação.
Figura 1: Fluxograma temático da pesquisa. Fonte: Adapatação da autora, Paiva (2020). 


\subsection{Objetivos}

Como objetivo geral, a pesquisa pretendeu o seguinte:

Contribuir para o desenvolvimento técnico e científico de questões relacionadas ao design gráfico e aos métodos editoriais e projetuais empregados no processo de produção de livros didáticos produzidos por e voltados para indígenas, tomando como objeto de estudo um subconjunto das publicações intituladas como "Coleção Autoria Indígena", publicadas pela Comissão Pró-Índio do Acre durante o período de 1983 a 2008: as obras voltadas à etnia Kaxinawá.

Um conjunto de 4 objetivos específicos permitiu alcançar os propósitos da pesquisa, quais sejam:

1. Compreender e analisar o conceito de autoria indígena, assim como os contextos cultural, histórico e social do desenvolvimento do projeto de educação da Comissão Pró-índio do Acre;

2. Investigar os métodos e estratégias editoriais aplicados pela Comissão Pró-índio do Acre no desenvolvimento dos livros da Coleção Autoria Indígena, abrangendo sua produção, distribuição e avaliação, a partir de entrevistas realizadas com membros da equipe da entidade e da compreensão do contexto histórico no qual a produção dos livros se insere;

3. Caracterizar o comportamento gráfico dos livros que compõem a Coleção Autoria Indígena, a partir da catalogação e registro das publicações, da compreensão das especificidades técnicas e culturais de acordo com os períodos temporais e de entrevistas com os responsáveis pela programação visual dos livros; e,

4. Examinar, através de métodos de análise gráfica, análise de imagens, e revisão bibliográfica temática, as maneiras pelas quais a configuração gráfica das publicações de autoria kaxinawá expressa e se articula com a cosmologia e as manifestações visuais tradicionais dessa etnia.

\subsection{Métodos}

A investigação desenvolveu-se enquanto pesquisa qualitativa, exploratória, do tipo estudo de caso (FLICK, 2009) e que envolve, também, pesquisa documental - já que o corpus de sua análise é constituído por documentos anteriormente não investigados a partir da ótica do design gráfico e da análise de imagens (SANTOS et al., 2011).

O método proposto parte da elaboração da pergunta fundamental de pesquisa, elaborada de forma a incluir todo o seu escopo e abarcar o alcance dos 4 objetivos descritos acima, cujo enunciado é apresentado a seguir:

Como se caracterizam, em termos estéticos, semânticos e projetuais, as ilustrações dos livros didáticos de autores kaxinawá publicados pela Comissão Pró-Índio do Acre como parte do projeto "Uma experiência de autoria dos índios do Acre", do ponto de vista da compreensão dos contextos histórico, social e cultural nos quais os impressos se inserem; dos recursos técnicos empregados (métodos editoriais, tecnologias de composição e reprodução gráfica); das formas de representação utilizadas e da articulação com a cosmologia e as manifestações visuais tradicionais dessa etnia?

Para facilitar a compreensão do problema de pesquisa, a questão fundamental divide-se em quatro subproblemas cuja resolução determina, também, as etapas de desenvolvimento do estudo em questão, culminando na resposta completa da pergunta fundamental. 
1. Quais são os principais aspectos conceituais da autoria indígena e do desenvolvimento do projeto de educação indígena da CPI-AC?

Nesse ponto procurou-se examinar as concepções e discussões teóricas fundamentais para a compreensão da autoria indígena, assim como dos contextos cultural, histórico e social nos quais se insere o processo de letramento e educação indígena encabeçado pela CPI-AC no Acre, através de revisão bibliográfica temática, com ênfase nos materiais de autoria indígena produzidos pela própria instituição.

2. Quais são os métodos editoriais e adotados pela CPI-AC no desenvolvimento dos livros da Coleção Autoria Indígena, e como se dá a produção, distribuição e avaliação dos mesmos?

Analisar os aspectos editoriais, projetuais e gráficos dos livros da Coleção Autoria Indígena, a partir da compreensão dos métodos desenvolvidos e aplicados pela CPI-AC para a produção das publicações, das relações entre editores, autores e designers, assim como das tecnologias de composição e reprodução gráficas utilizadas. Para tal, empregou-se os dados levantados a partir de entrevistas semipadronizadas em profundidade com membros da equipe da entidade e designers dos livros publicados.

3. Como se caracteriza o comportamento gráfico dos livros da Coleção Autoria Indígena de acordo com o passar do tempo?

Registrar, catalogar e caracterizar os aspectos gráficos dos livros da Coleção, atentando-se para seus aspectos mais significativos e as relações entre os contextos histórico e social nos quais sua produção está inserida, e como os mesmos podem refletir-se visualmente nas publicações. Os dados necessários derivam da investigação dos impressos em si, além de outros insumos preservados no Centro de Documentação e Pesquisa Indígena (CDPI), e do seu cotejamento com os dados levantados para os subproblemas 1 e 2 .

4. Como a configuração gráfica das publicações de autoria kaxinawá expressa e se articula com as especificidades culturais e cosmológicas, assim como com outras representações visuais tradicionais dessa etnia?

Empreender a análise dos projetos gráficos e das ilustrações dos livros de autoria kaxinawá, com base na compreensão da cosmologia e das representações gráficas autóctones dessa etnia, combinada às informações exploradas nos subproblemas anteriores, no intuito de captar os principais elementos compositivos e estruturantes de tais composições, assim como seu papel na constituição das publicações em questão.

As principais técnicas de levantamento e tratamento de dados, utilizadas em momentos distintos, de acordo com cada subproblema da pesquisa e de suas respectivas indagações exploratórias, são descritas com maiores detalhes a seguir.

- Entrevistas semiestruturadas em profundidade: entrevistas com roteiros previamente estruturados compostos de questões abertas, com o intuito de obter percepções subjetivas dos sujeitos entrevistados de acordo com suas opiniões e experiências próprias. $\mathrm{O}$ roteiro das entrevistas funcionou como uma seleção de tópicos-guia que podem ser aprofundados pelo entrevistador a partir das respostas fornecidas (FLICK, 2009, pgs. 148-154). Estas entrevistas foram realizadas com os membros do conselho editorial e da equipe da CPI-AC. 
- Entrevistas semipadronizadas (ou entrevista com especialistas): entrevistas com roteiro de perguntas abertas que se repetem para diversos entrevistados, com a possibilidade de aprofundamento em tópicos distintos, de acordo com o entrevistado em questão e suas respectivas respostas (FLICK, 2009, pgs. 158-9). Essa modalidade se aplicou às entrevistas com os responsáveis pelos projetos gráficos dos livros, onde um mesmo roteiro se repete, porém ajustes são feitos de acordo com as especificidades de cada projeto (sobre o qual a entrevista baseia-se).

- Levantamento, catalogação, tabulação e classificação do acervo: através do contato direto com o acervo da Coleção Autoria Indígena, realizou-se o levantamento de todos os títulos, datas de publicação, autores, características físicas e gráficas específicas, de acordo com tópicos de interesse que pudessem contribuir para os objetivos almejados com a análise. Tais características e dados foram coletados através do preenchimento de formulários, posteriormente tabulados, de modo a permitir a produção de dados estatísticos que complementam a análise qualitativa. Este procedimento baseia-se nos métodos utilizados para pesquisas em memória gráfica (COLLI, et al., 2011), com os quais a pesquisadora teve contato durante a graduação, ao participar do núcleo de pesquisa atualmente denominado Laboratório de Design, História \& Tipografia (LadHT) da Universidade Federal do Espírito Santo.

- Análise gráfica dos livros: reconhecimento dos aspectos gráficos e projetuais dos livros de autores kaxinawá, de acordo com o método proposto por Twyman (1979). O método e sua aplicação são descritos em maiores detalhes no Capítulo 4.

- Análise de imagens: investigação da combinação entre as dimensões de interpretação semiótica e os "fatores visuais" de composição imagética, conforme proposto por Goldsmith (1980). O método e sua aplicação são descritos em maiores detalhes no Capítulo 4.

- Análise das entrevistas: para que se pudesse explorar de modo sistemático e eficiente as informações coletadas nas entrevistas realizadas, optou-se por desenvolver um método baseado na análise de conteúdo (BAUER, 2011), adaptado às necessidades específicas da pesquisa desenvolvida. Desse modo, as entrevistas foram cuidadosamente transcritas, estudadas, separadas em unidades semânticas homogêneas e classificadas em categorias temáticas induzidas a partir das informações consideradas mais relevantes para os objetivos e questões de pesquisa pré-determinados (MORAES, 2011). A matriz comparativa gerada após tai processos foi, então, utilizada como base para a descrição e análise do conteúdo apresentado pelos entrevistados. Como a quantidade de entrevistas realizadas não é tão significativa, optou-se por simplificar o processo, excluindo-se as matrizes estatísticas e a codificação tradicionalmente aplicadas à análise de conteúdo.

No intuito de facilitar a compreensão da estruturação do método utilizado, optou-se por sistematizar as respectivas técnicas de coleta e tratamento de dados em etapas, conforme é descrito a seguir.

\section{Etapa 1}

A pesquisa teve início com uma primeira visita exploratória ao acervo da CPI-AC, no CDPI, em julho de 2018. Durante aproximadamente um mês de imersão no acervo, a pesquisadora realizou a catalogação e o registro fotográfico inicial de todas as publicações que constituem a Coleção Autoria Indígena. 
Paralelamente, realizou-se um levantamento bibliográfico dos métodos possíveis para a análise dos livros, assim como dos principais conceitos de interesse da pesquisa, a saber: a história do movimento indígena no Acre; autoria, letramento e literatura indígena; visualidade, cultura visual e material; cultura e comunicação indígena.

\section{Etapa 2}

Os dados levantados em campo foram, então, sistematizados e tabulados, gerando relatórios gerais sobre o acervo e possibilitando a sondagem de tópicos de interesse - de acordo, também, com o levantamento bibliográfico realizado. A sistematização resultante desta etapa foi apresentada na banca de qualificação da pesquisa, em abril de 2019. A partir das valiosas colaborações dos componentes da banca ${ }^{5}$, pode-se realizar o recorte adequado do objeto de estudo para a análise proposta, os livros da Coleção que são especificamente escritos por e voltados para a etnia Kaxinawá. Também foi possível definir o método de análise mais adequado, assim como a abordagem pretendida: o foco na análise dos elementos gráficos, com ênfase nas ilustrações, e suas relações com a cosmologia e outras representações visuais tradicionais daquela etnia.

\section{Etapa 3}

A partir da definição do recorte e da abordagem, foram preparados os roteiros para entrevistas, assim como o levantamento bibliográfico relativo às especificidades culturais dos Kaxinawá. Em nova visita ao acervo, dessa vez durante cerca de três meses (maio, junho e julho de 2019), os livros dos autores kaxinawás foram registrados por completo, e os dados previamente levantados foram revisados. As entrevistas foram realizadas e transcritas, e os dados foram novamente tabulados e sistematizados.

\section{Etapa 4}

Analisou-se os livros selecionados, de acordo com as propostas de Villas-Boas (2009), Twyman (1970) e Goldshmith (1970) e com o cotejamento dos dados levantados nas etapas anteriores. Realizou-se, também, a análise de conteúdo das entrevistas.

\section{Etapa 5}

O processo de tratamento dos dados se deu de acordo dos pressupostos colocados por Flick (2009) para o tratamento de dados em pesquisas qualitativas. Dessa forma, em um primeiro momento, ocorreu uma pré-seleção dos dados brutos, de acordo com a sua pertinência com os subproblemas da pesquisa. Os dados selecionados passam, então, por um exame minucioso, no intuito de induzir categorias conceituais de classificação, correspondentes a cada conjunto de dados. Gera-se, a partir daí, uma matriz de classificação com o conjunto de categorias conceituais, combinando a abordagem indutiva e a dedutiva.

A seguir, os dados selecionados foram desmembrados e, em sequência, indexados de seus grupos originais e re-agrupados em categorias geradas através da matriz desenvolvida. Isso possibilitou uma análise mais profunda dos conjuntos de elementos reunidos em cada categoria conceitual, identificando padrões abstratos de associação.

Em última etapa, atingiu-se um grau mais elevado de abstração, visando identificar o sentido geral das conexões feitas dentro das categorias, que, finalmente, revertem-se nos resultados finais da pesquisa.

5 Profa. Dra. Priscila Lena Farias (FAUUSP) e Profa. Dra. Eliete Pereira (UEMG). 


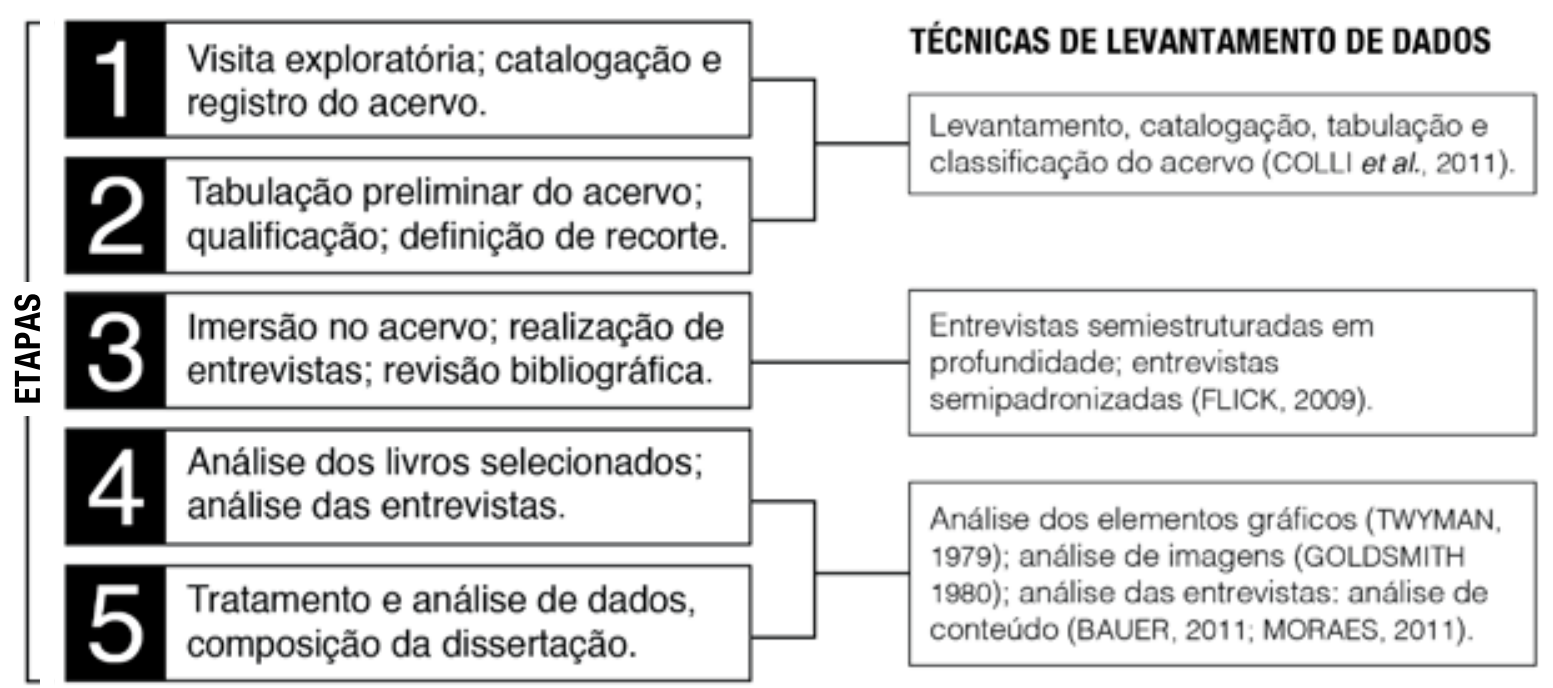

Figura 2: Esquema com a síntese das técnicas de levantamento de dados utilizadas nas respectivas etapas de desenvolvimento da pesquisa. Fonte: Adaptação da autora, Paiva (2020)

\subsection{Delimitações}

É importante frisar que esta pesquisa diz respeito, especificamente, ao estudo e análise dos métodos, técnicas e construções - editoriais e gráficas, dos livros de autoria indígena publicados na "Coleção Autoria Indígena", pela CPI-AC.

Não se pretendeu, portanto, verificar, julgar ou criticar os conteúdos selecionados para publicação, as relações da instituição com os autores indígenas ou mesmo a atuação da Comissão em si.

A meta final foi, essencialmente, auxiliar em melhoras relativas ao papel do design e do designer nos métodos utilizados. Em suma, concorda-se com Diniz (2007), em sua consideração sobre o papel do designer de tipos em publicações de línguas indígenas, expandindo-se a reflexão ao design gráfico dos impressos de autoria indígena, de forma geral:

Por fim, frisamos que o/a designer gráfico e de tipos está na ponta de todo o processo de uso da escrita e elaboração de publicações em línguas indígenas. Não nos cabe questionar a pertinência dos alfabetos e grafias adotadas pelos diversos grupos indígenas para representação de suas línguas, nem interferir no conteúdo de suas publicações. A sociedade não-indígena tem hoje a responsabilidade de atender às demandas dos povos indígenas sem interferir em seus processos e autonomia. $O$ nosso papel nesse contexto é o de oferecer ferramentas que garantam a qualidade e fidelidade ao projeto elaborado pelas populações indígenas e facilitem o trabalho de profissionais - antropologia, pedagogia, lingüística, etc. - que estarão em maior contato com elas, permanecendo atentos e atentas à sabedoria, riqueza cultural, à enorme diversidade das populações indígenas e, principalmente, dispostas a ouvir suas demandas (DINIZ, 2007, p. 45).

Além disso, o escopo desta pesquisa foi direcionado, especificamente, para o estudo e análise da emissão dos projetos realizados, e não abrange, consequentemente, o estudo de sua recepção por usuários indígenas ou não indígenas, estudo que demandaria ferramentas de levantamento de dados mais complexas e outras bases conceituais e teóricas, assim como o contato direto a longo prazo com os usuários. 


\section{0 movimento indígena no Acre, a CPI-AC e a autoria indígena}

Para que se possa compreender, do modo mais abrangente possível, os métodos editoriais e de composição dos livros da Coleção Autoria indígena, faz-se fundamental estudar o contexto histórico e social das etnias indígenas que habitam o estado do Acre. Atenção especial é dada aos Kaxinawá, foco do recorte analítico do capítulo 4 dessa dissertação. Nesse primeiro momento, contudo, buscou-se compreender melhor as movimentações sociais dessa etnia, desde os primeiros contatos com não-indígenas, ainda no final do século XIX, deixando-se para o capítulo 4 as considerações a respeito de concepções socioculturais diretamente relacionadas à sua cosmologia específica.

A história da fundação da CPI-AC deriva das transformações políticas e econômicas sofridas e protagonizadas por esses povos, e seu entendimento também é importante para que se possa captar os métodos editoriais desenvolvidos pela instituição, e como os mesmos se relacionam ao desenvolvimento do letramento indígena no Brasil, assim como ao conceito de autoria indígena.

Assim sendo, tais tópicos são explorados nesse capítulo. Releva-se que há copiosa bibliografia disponível sobre a história dos índios do Acre, embora geralmente os autores tratem do tópico de modo específico para cada etnia, e especialmente sobre os Kaxinawá. Tendo em vista a necessidade de um recorte, já que o objetivo dessa pesquisa está muito mais direcionado à compreensão geral dos temas, e não à realização de um enorme levantamento teórico, deu-se preferência aos materiais de autoria indígena, em particular aqueles publicados pela CPI-AC. Utilizou-se, também, os relatos e análises desenvolvidos por membros não-indígenas da equipe da entidade, assim como as entrevistas realizadas com os mesmos durante o levantamento de dados desta pesquisa.

\subsection{Uma breve história dos índios do Acre}

No livro Índios no Acre - História e Organização, os pesquisadores indígenas Edson Medeiros Ixã Kaxinawá e Joaquim Paulo Maná Kaxinawá dividem a história dos índios do Acre em 5 momentos-chave, que se associam às lutas indígenas no Estado: "o tempo das malocas, o tempo das correrias, o tempo do cativeiro, o tempo dos direitos e o tempo da história presente" (KAXINAWÁ et al., 199-, p. 65). A compreensão da história de tais lutas é fundamental também para se compreender a história da CPI-AC, agente central da publicação da Coleção Autoria Indígena, objeto desta dissertação.

Dessa forma, "o tempo das malocas" refere-se ao período prévio ao contato com a sociedade não-indígena ${ }^{1}$, quando os então 50 (atualmente reduzidos a 12) povos indígenas habitantes da área que tornar-se-ia o estado do Acre (Ibid., p. 63), organizavam-se de acordo com suas próprias tradições e costumes. A esse "tempo" remonta o nascimento das mitologias de cada etnia, assim como das práticas tradicionais de pesca, caça e agricultura.

1 O contato entre indígenas e não-indígenas tem início em anos diferentes de acordo com cada etnia específica, mas, de modo geral, se dá a partir de meados do século XIX. 


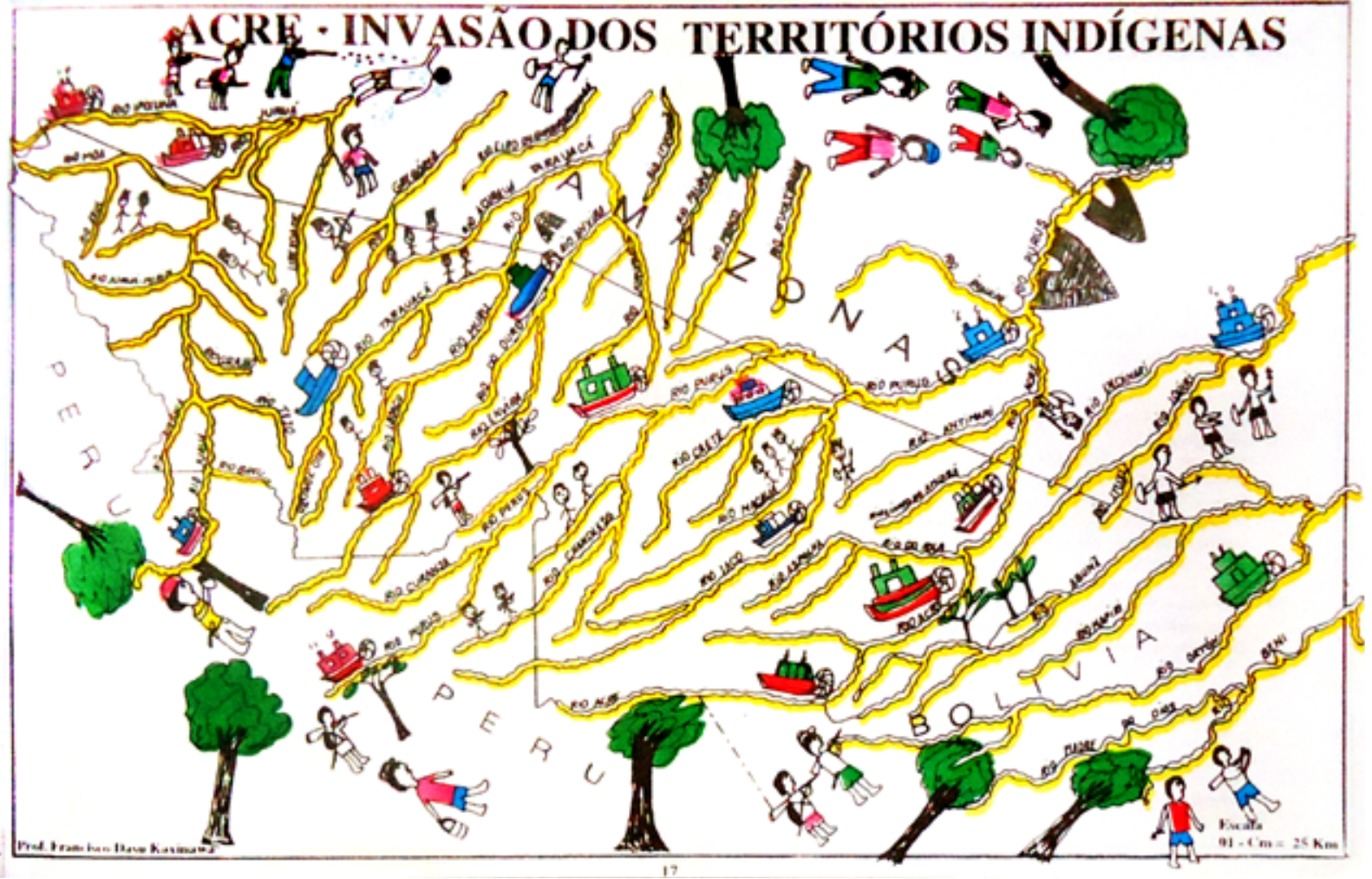

Figura 3. llustração do professor Francisco

Dasu Kaxinawá, parte do Atlas Geográfico Indígena (publicado pela CPI-AC em

1996), que demonstra as principais rotas de chegada dos seringueiros $\mathrm{e}$ caucheiros.

Fonte: GAVAZZI, RESENDE, 1996, p. 17
Com o crescimento da busca por látex para a produção de borracha, em meados do séc. XIX, passaram a ocorrer expedições advindas dos estados do Amazonas e do Grão Pará, contando, em grande parte, com trabalhadores nordestinos, que chegaram na região acreana através dos rios Purus e Juruá. Simultaneamente, peruanos passaram a adentrar, também, o território, em busca de caucho - borracha. Chega-se, então, ao "tempo das correrias", iniciado entre o final do século XIX e o início do século XX, quando as populações indígenas passaram a mover-se no território, no intuito de escapar das muitas expedições, que traziam o rastro da destruição. Em situação clara de desvantagem, dizimados pelas armas de fogo e as doenças trazidas pelo branco, os indígenas que sobreviveram passaram a adentrar novos territórios, espalhando-se em famílias pelas cabeceiras dos rios e em pontos mais densos da floresta. Os que não puderam escapar passaram a ser explorados pelos patrões seringalistas, escravizados enquanto mão de obra na exploração do látex (KAXINAWÁ et al., 199-, pgs. 92-100).

Inicia-se então o "tempo do cativeiro". Cada etnia foi integrada ao sistema seringalista em anos e de formas distintas, mas o processo tem início, de modo geral, nas primeiras décadas do século XX. Vivendo em colocações ${ }^{2}$ e subordinada aos "patrões" (donos dos seringais), a população indígena encontrava-se em situação de exploração e dependência, sendo obrigada a pagar taxas para utilizar as estradas entre colocações, assim como para viver dentro do seringal. Eram obrigados a consumir os produtos básicos para sua

2 O seringal é o espaço total do cultivo e exploração de seringa. Colocações são as partes menores que constituem o seringal, onde localizam-se os núcleos familiares dos seringueiros, em grandes clareiras abertas na mata. Uma colocação é constituída pelas casas das famílias que ali habitam, seus quintais e terreiros, roçados para a produção agrícola, estradas de seringa (caminhos entre as árvores de onde se estrai o látex). Conectadas por estradas abertas no meio da mata (que podem ser trilhas estreitas, os varadouros, ou mais alargadas para a passagem de motocicletas, os ramais), podem ser "de centro", caso estejam mais próximas da área central do seringal, geralmente onde se localiza o barracão, ou mais distantes, afastadas e mais inseridas dentro da floresta. $O$ barracão é onde o patrão seringalista comercializa artefatos (munição, facas etc) e insumos básicos - alimentos, bebidas, querosene e assim por diante (AQUINO, IGLESIAS, 1994). 


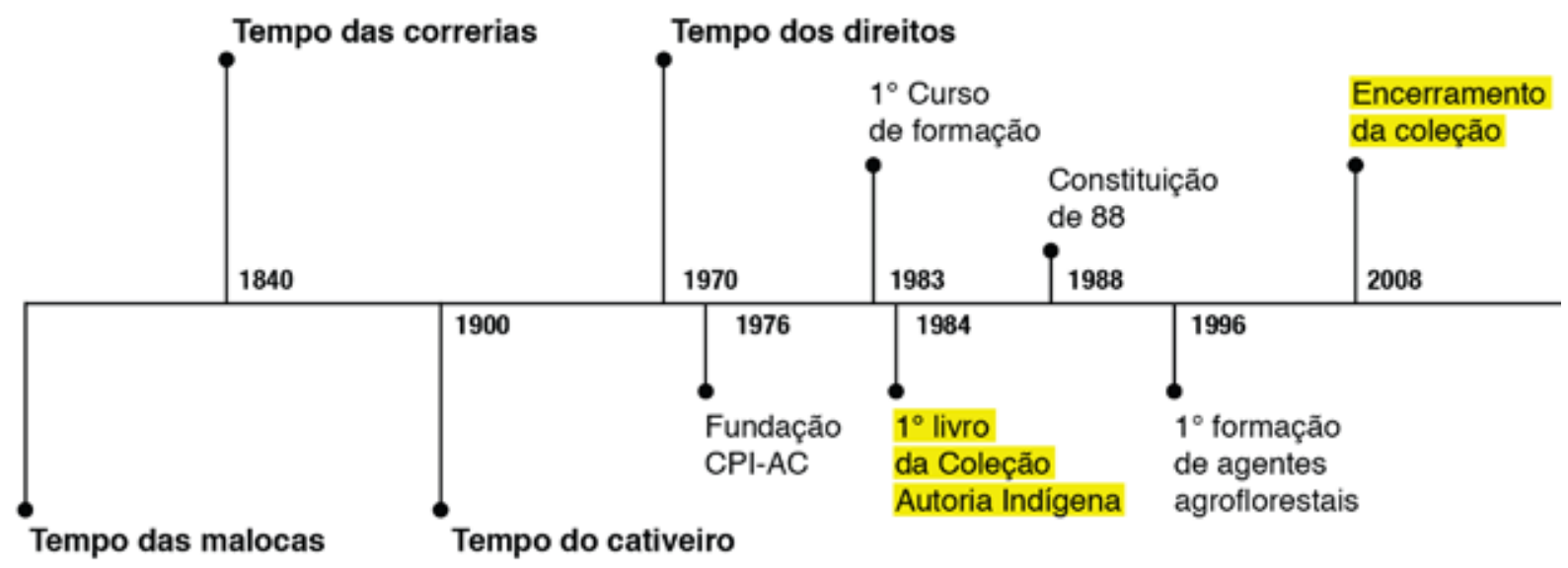

sobrevivência nos "barracões", onde os patrões comerciavam mantimentos e compravam o látex produzido. As transições ocorriam de maneira enganosa, tirando proveito da pouca compreensão do português e da matemática por parte dos "caboclos seringueiros". Práticas de "amansamento", onde o patrão entrava na mata para buscar índios "brabos" e trazer para o roçado eram comuns, incluindo até marcações feitas na pele para sinalizar o "dono" daquele indígena, responsável pelo seu amansamento (Ibid., p. 108).

"No tempo do cativeiro, o índio não vivia liberto. Era conhecido por caboclo e vivia cativo dos débitos no barracão de seu patrão. Custou muito sofrimento até a FUNAI chegar ao Acre e informar aos índios que eles tinham direito de ter suas terras indígenas demarcadas" (Ibid., p. 104). Chega, finalmente, o "tempo dos direitos". A FUNAI (Fundação Nacional do Îndio) inicia sua atuação no estado em 1976. Nessa época, os governos estaduais e federais ainda não reconheciam sequer a existência de populações indígenas na região, sendo eles considerados "caboclos" (Ibid., p. 119). Já existia, porém, o CIMI (Conselho Indigenista Missionário), organização da igreja católica voltada para a defesa de direitos humanos desses povos. O CIMI foi um dos responsáveis pela organização de lideranças indígenas, que pressionaram a ação da FUNAI no estado. A década de 1970 caracteriza-se, no cenário nacional do movimento indígena, como o momento inicial de articulação das lideranças em direção à busca por direitos (MUNDURUKU, 2013).

\footnotetext{
E tudo começou em meados da década de 70 , quando as lideranças indígenas ultrapassaram as esferas de suas próprias comunidades originárias. Até então, essas comunidades estavam voltadas muito mais para suas próprias necessidades e dificuldades de sobrevivência. Para isso procuraram resolver suas demandas em nível local, sem se envolverem com os problemas e dificuldades dos povos que estavam além de suas fronteiras. (MUNDURUKU, 2013, p. 51)
}

Em 1979 é fundada a Comissão Pró-Índio do Acre, com o objetivo de auxiliar os povos indígenas na obtenção, manutenção e cumprimento de seus direitos. Em conjunto com a FUNAI e o CIMI, e as crescentes lideranças de diversas etnias, a CPI-AC passa a atuar no processo de demarcação das primeiras terras indígenas (TIs) do estado. $\mathrm{O}$ extenso processo de regulamentação das terras dá início ao "tempo do governo dos índios (o tempo presente)" (KAXINAWÁ et al., 199-, p. 131).

Com a demarcação das TIs, novos desafios entram em cena: reorganizados em cooperativas e associações próprias, era necessário às populações indígenas gerenciar e estruturar suas atividades, tomando para si o controle da gestão e das produções oriundas de seus territórios (Ibid.).
Figura 4. Linha do tempo com marcos temporais das populações indígenas do Acre e da história da CPI-AC. Fonte: Adaptação da autora a partir de Monte (1996) e Kaxinawá (et al., 199-) 


\subsection{História socioeconômica dos Kaxinawá no Acre}

Os Kaxinawá, assim como as outras etnias denominadas nawa, formam um subgrupo da família linguística Pano, por possuírem características culturais e línguas semelhantes, além de "terem sido vizinhos por tanto tempo quanto existem fontes históricas sobre a região" (LAGROU, 1991, p. 12). As etnias pertencentes a esse subgrupo se autodenominam huni kuĩ, expressão comumente traduzida como "gente verdadeira", apesar de haverem divergências entre pesquisadores, tanto no que diz respeito à grafia (huni kuĩ, honi kon, uni koi etc), quanto na compreensão dessa tradução (OLIVEIRA, 2016). Segundo Lagrou (1991) há, até hoje, uma confusão em relação à denominação desses povos, advinda da falta de consenso entre os denominadores e os denominados. De modo superficial, as etnias Pano referem-se a si mesmas como huni kuĩ, e aos outros povos (também da família Pano) como nawa - Lagrou (Ibid., p. 12) cita como exemplo: "Kulina são chamados de pisinawa (os que fedem) pelos Kaxinawá, enquanto que os Paranawa chamavam os próprios Kaxinawá de pisinawa". Nesse contexto, o nome kaxinawá teria sido "originalmente um insulto. Kaxi significa morcego, canibal, mas pode significar também gente com o hábito de andar de noite" (Ibid.). Segundo o texto "Os índios do Acre", escrito por Sálvio Barbosa Kister Kaxinawá, o nome lhes foi designado pois, no primeiro encontro entre um branco e um kaxinawá, o último estava a brincar com um morcego (MONTE, 1984).

Antigamente, os índios e os brancos não se conheciam. A primeira vez que os brancos encontraram um índio, este estava sem roupa e brincava com um morcego que tinha achado num oco de pau. Os brancos perguntaram ao índio quem era ele e ele, que não entendia o português, respondeu na sua língua: eu tô matando morcego.

O morcego a gente chama kaxi. Então o branco botou um nome nele - seu povo e você se chama kaxinawá. (KISTER KAXINAWÁ In MONTE, 1984, p. 29)

De todo modo, a autodesignação Huni kuĩ para referir-se aos Kaxinawá tem ganhado espaço no meio indigenista e, apesar de ainda não ser considerada como consenso, é reivindicada pelos membros dessa etnia que habitam o território acreano, sendo a forma como os mesmos se auto reconhecem (OLIVEIRA, 2016).

Os territórios habitados pelos Kaxinawá no $\mathrm{Acre}^{3}$ localizam-se nas áreas dos rios Purus, Envira, Murú, Humaitá, Tarauacá, Jordão e Breu, e dividem-se em 12 TIs, das quais 11 são totalmente regularizadas, e uma está ainda nesse processo. De acordo com relatos mais antigos, as comunidades kaxinawá habitavam, originalmente, as margens de três afluentes do Envira: Muru, Humaitá e Iboaçu (LAGROU, 1991). O "tempo das correrias" (KAXINAWÁ, et al., 199-), para os Kaxinawá, se inicia no final do século XIX, com a chegada de peruanos em busca de látex (TASTEVIN, 1925, apud LAGROU, 1991). O contato, marcado pela violência e pelos surtos de doenças contagiosas, foi avassalador, causando a diminuição da população indígena da região. Por outro lado, a quantidade de imigrantes nordestinos, em especial cearenses, aumentou exponencialmente até a década de 1920 (LAGROU, 1991).

3 Além das TIs no Acre, há um "considerável número de famílias que vive hoje nas cidades de Santa Rosa, Tarauacá, Jordão, Feijó e na capital, Rio Branco" (OLIVEIRA, 2016, p. 17). Os Kaxinawá também habitam 11 "comunidades nativas" em território peruano, nas áreas do alto rio Purus e do rio Curanja (IGLESIAS, 2014, apud OLIVEIRA, 2016, p. 17). 
Figura 5. Linha

do tempo: história socioeconômica dos Kaxinawá no Acre.

Fonte: Adaptação

da autora a partir de

Kaxinawá (et al., 199-),

Aquino \& Iglesias

(1994); e Lagrou (1991).

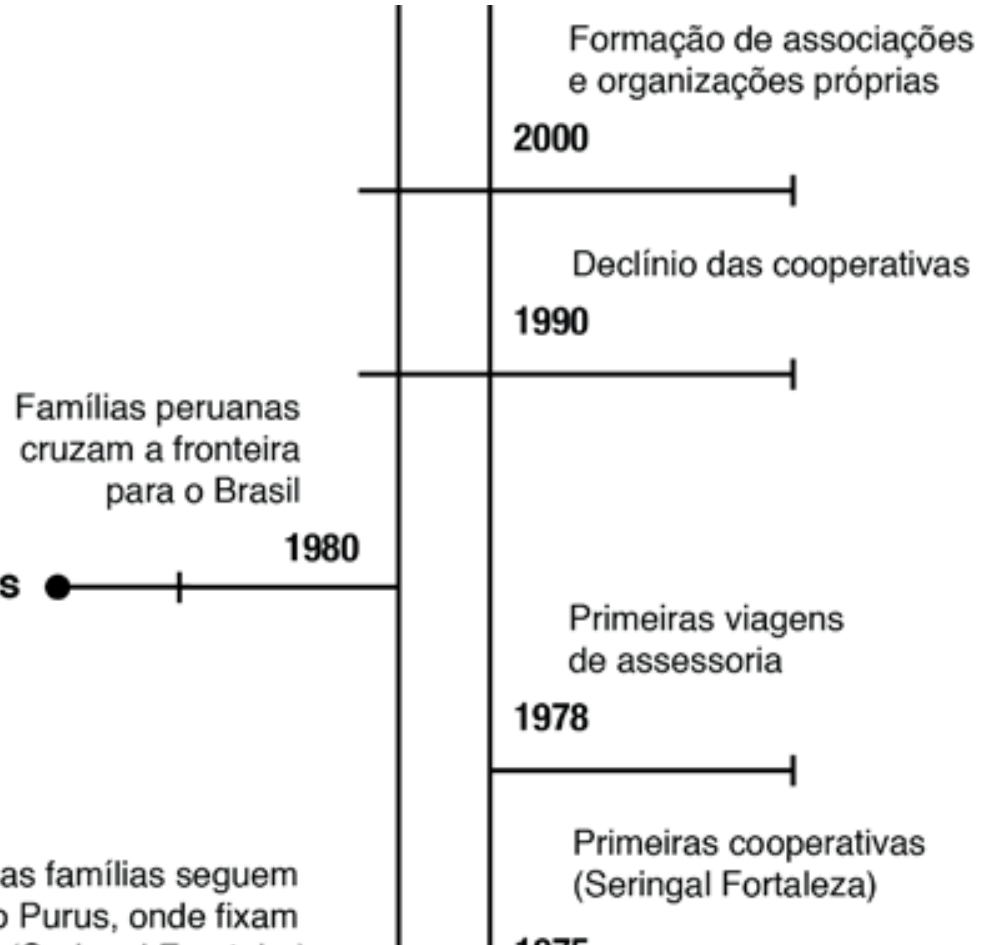

1975

1980

Primeiras viagens

de assessoria residência (Seringal Fronteira)

\section{Tempo dos direitos}

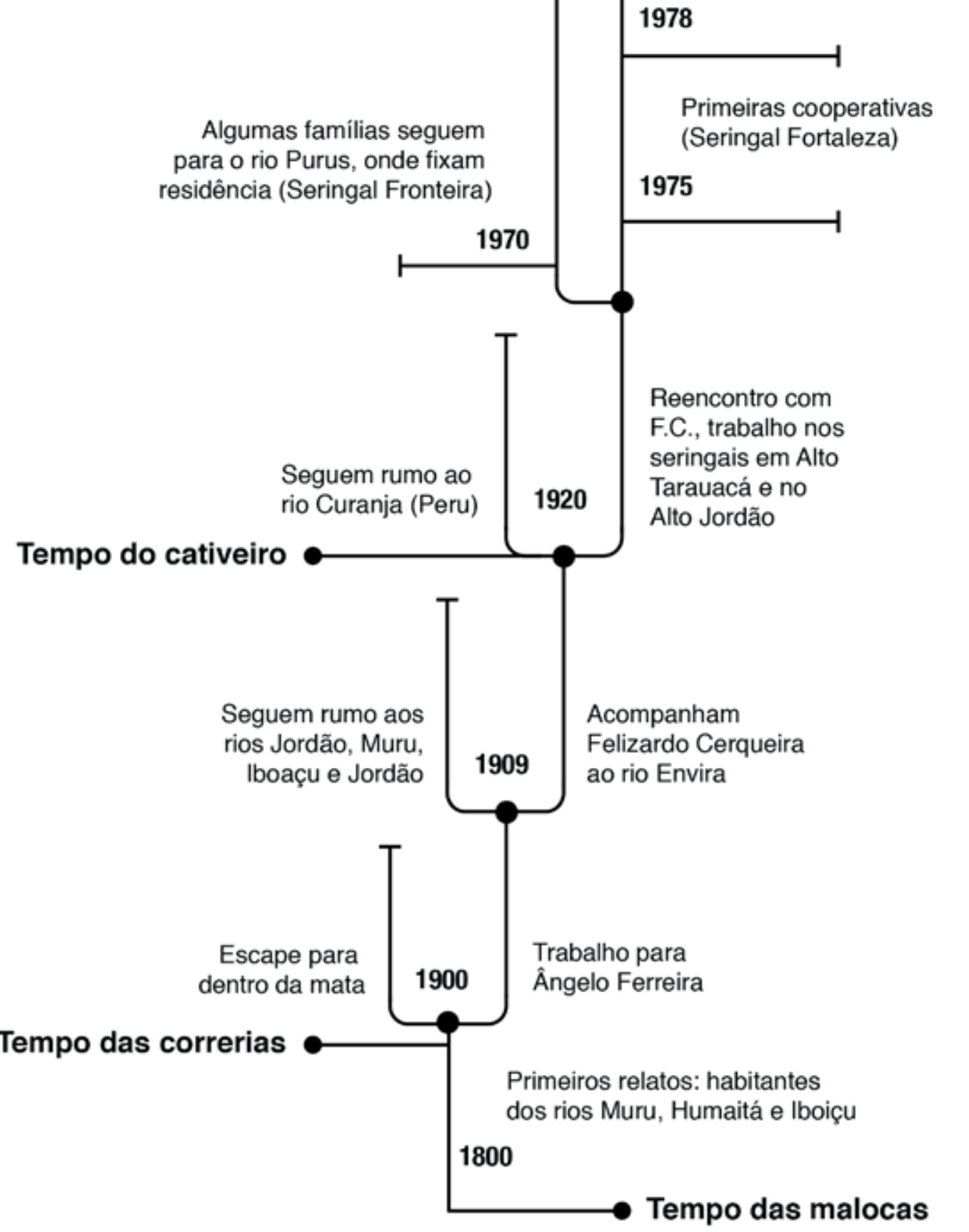


Figura 6: Páginas do miolo do iivro Fábrica do Índio (CPI-AC, 1985), com relato sobre o trabalho com a seringa e ilustração do processo de defumação da borracha.

Fonte: Pesquisa de campo, Paiva (2019).

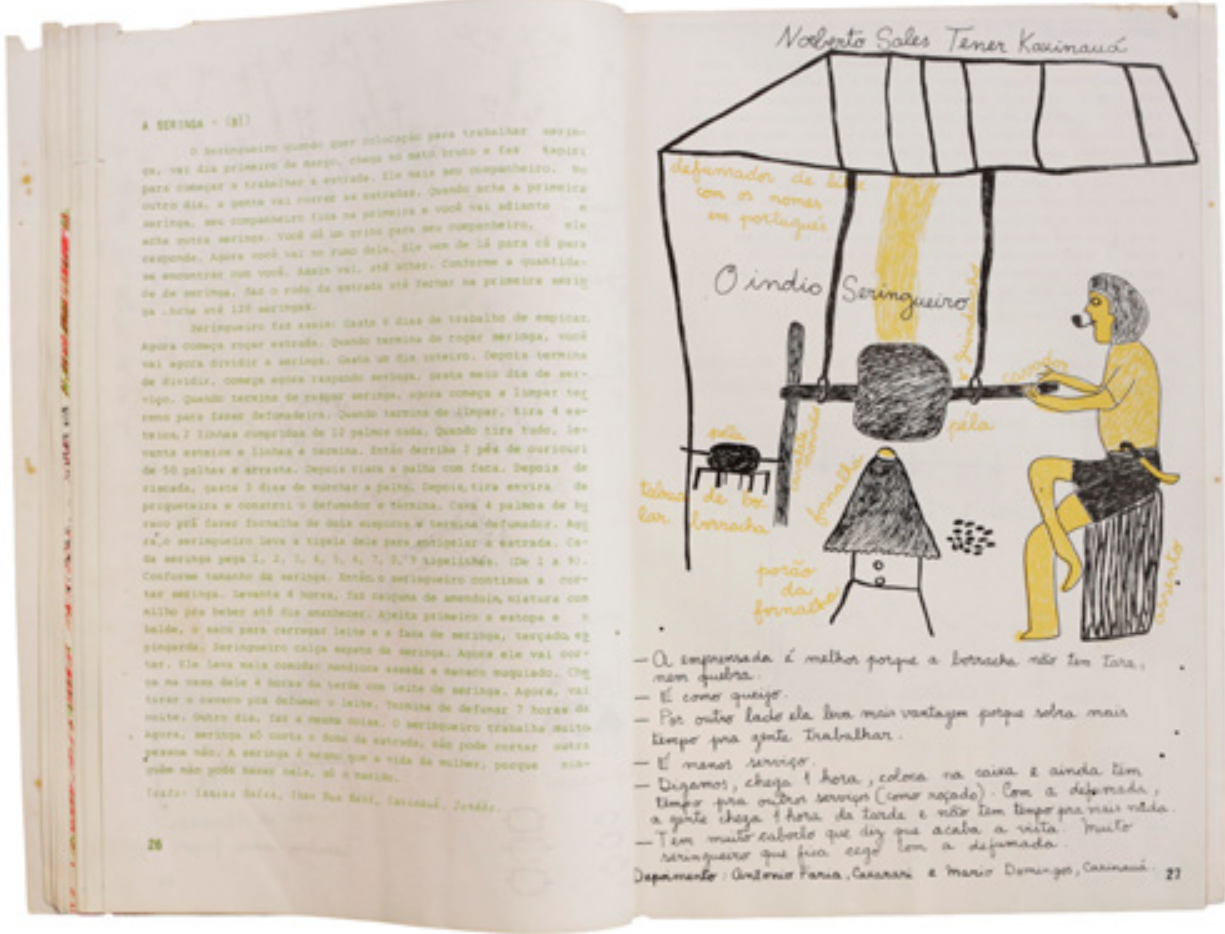

Enquanto uma parte da população kaxinawá, em vias de evitar novos enfrentamentos, buscou manter-se afastada dos seringais (adentrando cabeceiras de rios e igarapés mais distantes), outro grupo passou a trabalhar para o patrão Angelo Ferreira em seringais localizados nas margens do rio Tarauacá, onde eram responsáveis pela exploração do látex, pela abertura de varadouros e pela defesa do seringal contra "brabos".

Com a morte de Ferreira, em 1909, há uma nova divisão: uma parte do grupo dispersou-se nas áreas dos rios Muru, Iboaçu, Taraucá e Jordão. Outra parte acompanhou Felizardo Cerqueira até o alto Envira, continuando a trabalhar na exploração de látex (AQUINO, IGLESIAS, 1994).

Um violento confronto com caucheiros peruanos faria com que o grupo se dividisse novamente, e enquanto uma parcela adentrou o território peruano para estabelecer-se no rio Curanja, o restante seguiu "na direção das cabeceiras dos rios Envira e Tarauacá, onde, por volta de 1920, foram novamente agrupados por Felizardo Cerqueira" (Ibid., p. 12) que, contratado por patrões seringalistas dos altos rios Tarauacá e Jordão, encaminhou-se com os Kaxinawá para atuar como "polícia de fronteira" - protegendo os seringais em questão de ataques por parte de outros grupos indígenas (AQUINO, IGLESIAS, 2002). Cerqueira, apesar de célebre pelas violentas práticas de "amansamento" (que incluíam tatuar suas iniciais, "F.C.", nos corpos dos indígenas, como sinal para outros patrões de que determinado indivíduo fora por ele amansado e, portanto, lhe pertencia) era conhecido como um bom patrão. Falava fluentemente o hãtxa kuĩ ${ }^{4}$ e permitia a realização de rituais e festas tradicionais (AQUINO, IGLESIAS, 1994).

A assimilação dos Kaxinawá pela empresa seringalista se deu de modo mais acentuado a partir da década de 1920 , devido, em parte, à baixa no mercado da borracha (iniciada ainda em 1910). Com seus negócios comerciais prejudicados, os patrões passaram a ter dificuldades de continuar im-

4 Língua tradicionalmente falada pelos Kaxinawá / Huni kuĩ. Atualmente, 5 das 11 TIs majoritariamente habitadas por kaxinawá existentes no estado do Acre contam com a maioria da população fluente em Hãtxa kuĩ, enquanto, nas outras 6, apenas os mais velhos dominam a língua (LIMA KAXINAWÁ, 2014). 
portando mão-de-obra nordestina, sendo a indígena mais acessível e barata. Além disso, passou a existir a necessidade de diversificação da produção agrícola dos seringais, para além do látex, através de atividades de caça e roçado que os povos indígenas tradicionalmente dominavam na região. Assim sendo, os indígenas passaram a trabalhar na extração de madeira de lei, na abertura e manutenção de roçados e estradas, laborar nos engenhos de cana-de-açúcar, e fornecer a proteção contra ataques de indígenas "brabos" (AQUINO, IGLESIAS, 1994). Termina o "tempo das correrias" e se inicia o "tempo do cativeiro" (KAXINAWÁ, et al., 199-).

A inserção das populações indígenas nos seringais administrados por patrões seringalistas se estende até meados da década de 70 e é categorizada pelos seus membros como tempo do cativeiro. Os integrantes dessas populações passaram a ser indistintamente chamados de caboclos e a sofrer forte discriminação no interior dos seringais. Assim como os seringueiros cariús, se viram atrelados aos barracões dos patrões, sendo obrigados a pagar renda pela utilização das estradas de seringa e roubados nos preços da borracha e das demais mercadorias. Eram proibidos de praticar festas e rituais de suas tradições culturais, assim como de atualizar importantes aspectos de suas formas próprias de organização social e política. (AQUINO, IGLESIAS, 1994, p. 16)

Mais de meio século depois, já nos primeiros anos da década de 1970, algumas famílias saíram dos seringais localizados no rio Envira em direção ao Purus, onde fixaram residência. No final dessa mesma década, os Kaxinawás que habitavam no Peru passaram a cruzar a fronteira para reunir-se com as famílias brasileiras no então chamado seringal Fronteira. Posteriormente essas famílias fundariam as aldeias Fronteira, Nova Fronteira, Cana Recreio, Novo Recreio entre outras, que hoje formam a TI Alto Rio Purus (OCHOA, WEBER, 2013).

As duas aldeias Kaxinawá onde fiz minha pesquisa de Campo, Cana Recreio e Moema, no alto rio Purus, representam a junção destas duas tradições Kaxinawá do último século: a peruana e a brasileira. A primeira, que manteve sua autonomia por mais tempo e viu sua vida aldeal interrompida por menos tempo, é considerada mais " tradicional " (culturalmente mais indígena), apesar de ser marcada pelos missionários e o contato com os militares peruanos, (e) a segunda viveu durante anos de forma mais dispersa e se familiarizou com a cultura seringalista pelo trabalho de duas gerações para o patrão, mas vive hoje em dia um profundo processo de retomada das "tradições". (LAGROU, 2004, s/ p.)

Em 1975, segundo Terri Vale Aquino5 , a maior concentração de Kaxinawás encontrava-se nas margens do rio Jordão. Nessa época, um gupo de Kaxinawás havia herdado o seringal Fortaleza e estavam tendo dificuldades para vender a mercadoria produzida, devido à grande discriminação sofrida pelos mesmos na região. Segundo seu relato, apesar de toda a repressão

5 Antropólogo, realizou as primeiras pesquisas de campo junto aos povos indígenas no Acre. Foi um dos principais responsáveis pela elaboração e fundação institucional da CPI-AC. Desenvolveu e escreveu grande número de pesquisas a respeito das situações econômicas e sociais de várias etnias, e até hoje trabalha junto à entidade como consultor. Figura 
sofrida nos anos anteriores, ainda mantinham-se, além da língua, rituais, cantos, festas e práticas de medicina tradicional (AQUINO, 2019). Sobre as últimas, um exemplo interessante é mencionado pelo antropólogo ao tratar sobre um surto de malária que estava ocorrendo durante a viagem.

E ele [o pajé Carlito Catanhã] foi muito requisitado quando chegamos no Jordão. E eu levei muita cloroquina e primaquina e ele falou para mim assim: "olha txai, meus parentes estão me chamando para fazer cerimônia para eles de ayahuasca, eu posso fazer isso, mas eu sei que não vai curar malária, eu sei o que é malária, txai. É um protozoário no sangue e que tem que usar esse remédio mesmo que você está levando. Esses que curam mesmo. Mas a minha pajelança traz de volta o espírito daquela pessoa para aquela pessoa ficar mais... reagir melhor. Mas eles precisam do teu remédio. Eu queria que tu me cedesses esses remédios para mim poder medicá-los. Eu sei que tem que tomar quatro, três, três. A dose completa. No primeiro dia quatro. No segundo, três. E no terceiro dia, três". Era o tratamento que se fazia na época, com essa cloroquina. Enfim, eu achei muito interessante ele, como pajé, ver que os dois sistemas não são... excludentes. Um complementa o outro. Eu falei a medicina... esses índios são bem modernos, nesse sentido, de que não nega o valor de uma medicina tradicional, mas vê a importância da medicina ocidental também no processo de tratamento e cura de certas doenças. (AQUINO, 2019)

No seringal Fortaleza, ainda em meados da década de 1970, muitas das cerâmicas e outras peças tradicionais de artesanato produzidas no passado estavam guardadas, meio esquecidas, meio escondidas, assim como os conhecimentos técnicos de sua produção (MAIA $\left.{ }^{6}, 2019\right)$. As diferenças no que diz respeito ao conhecimento e valorização das práticas culturais tradicionais entre territórios é algo que se mantém até hoje, e costuma-se dizer que determinada TI "é mais cultura" ou "menos cultura", sendo as primeiras, geralmente, aquelas mais distantes dos centros urbanos e as segundas, mais próximas (SENA 7 , 2019). Essa é, contudo, mais uma constatação sobre os modos de vida de determinada comunidade do que um julgamento de valor.

fundamental quando se trata do movimento indigenista no Acre, Terri é comumente referido como txai Terri por seus colegas de trabalho e vida. Desse apelido já se pode deduzir a imensa proximidade que Terri construiu e ainda constrói junto aos povos indígenas do Acre. Txai é um termo utilizado, inicialmente, por povos da família linguística Pano para denominar parentes masculinos de variados graus de proximidade. Para os Kaxinawá, por exemplo, chama-se de txai cunhados, primos cruzados, avôs e tios-avôs (LAGROU, 1991). Com a intensificação do contato com o branco, especialmente no contexto de ações indigenistas e parcerias políticas, o termo passou a ser utilizado para denominar aqueles que se mostram aliados e parceiros dos povos indígenas, como, inclusive, uma estratégia de aproximá-los dos núcleos indígenas de convivência - o que McCallum denomina de "txai complex" (MCCALLUM, 1997, p. 126).

6 Maria Djacira Maia de Oliveira, Dedê Maia, é educadora especialista em alfabetização. Realizou o que viriam a ser as primeiras viagens de assessoria e fez parte da equipe de fundação da CPI-AC. Foi professora nos primeiros cursos de formação e organizou diversas publicações da Coleção Autoria Indígena. Além disso, foi responsável pelo projeto de construção do Centro de Pesquisa Indígena (CDPI), localizado na sede da CPI-AC em Rio Branco. Atualmente presta consultorias para a entidade.

7 Vera Olinda Sena faz parte da CPI-AC desde meados da década de 1980, atuando como educadora na área de alfabetização e assessora do projeto de educação indígena. Responsá- 

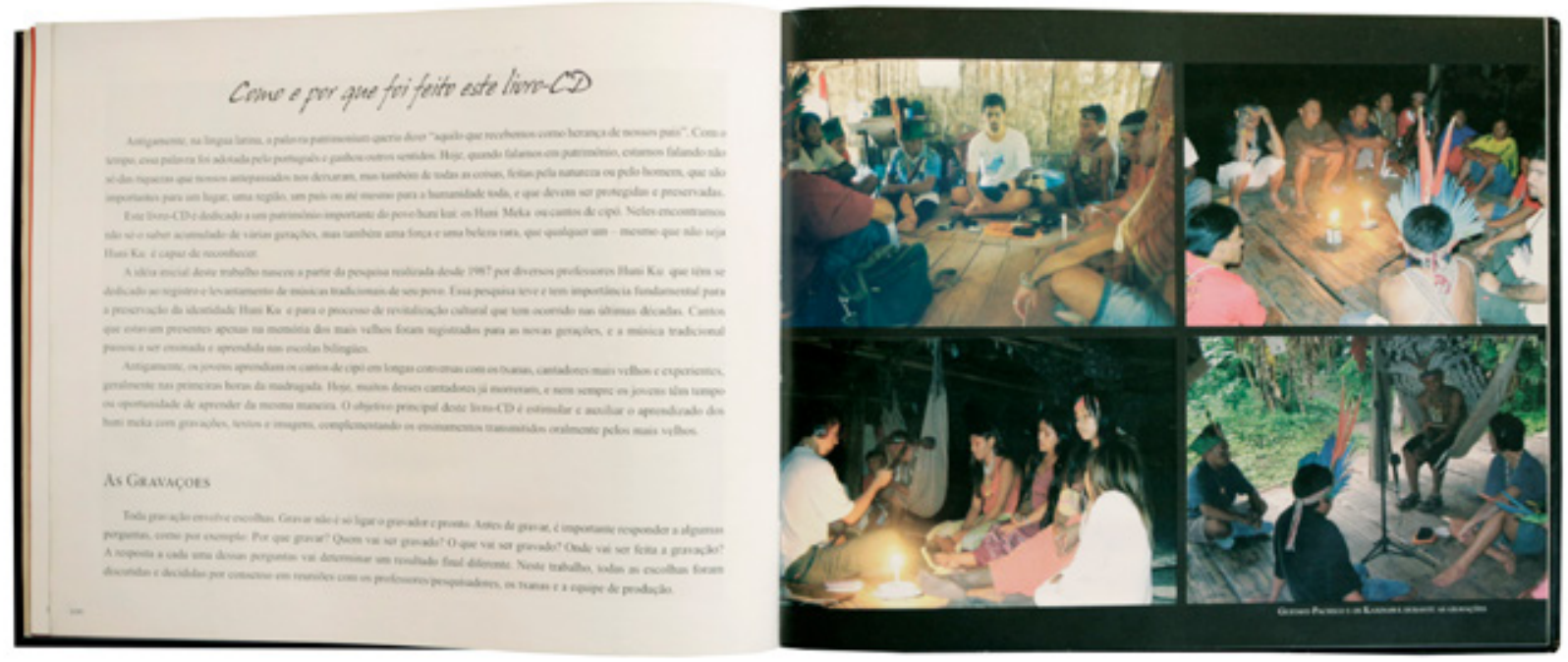

Reconhecidos por sua importante atuação no início das movimentações políticas iniciadas em meados da década de 1970, as lideranças kaxinawá tiveram papel fundamental na articulação do "processo de regulamentação das terras indígenas no Acre, até meados da década de 80 , ao visitar outras terras para socializar sua experiência e motivar seus parentes e outros povos a levar adiante essa luta" (KAXINAWÁ, IGLESIAS, 2010, p. 75). Além da reinvindicação pela demarcação e regularização das terras indígenas, as lideranças kaxinawá advogaram a necessidade da formação de professores e agentes de saúde indígenas, demanda que ocasionou o início dos cursos de formação de professores oferecidos pela CPI-AC no início dos anos 1980 (Ibid.).

A partir de 1994, a desestruturação das cooperativas, junto com a desnaturalização da matriz espacial dos seringais e o abandono das colocações de centro, resultaram no surgimento de novas aldeias, formadas por números variáveis de famílias extensas, ligadas por laços de parentesco, afinidade e vizinhança. Com o fim do antigo sistema de poder político centrado nos "caciques" e nos "cantineiros" das cooperativas seguiram-se intensos rearranjos das alianças familiares, associados à renovadas estratégias políticas, econômicas e territoriais das famílias extensas nas aldeias. (KAXINAWÁ, IGLESIAS, 2010, p. 76)

O declínio da economia relacionada à borracha ${ }^{8}$ fez com que as comunidades kaxinawá passassem a investir mais na criação de animais e na produção agrícola, com destaque para o manejo de práticas extrativistas, realizado, a partir de 1996, pelos agentes agroflorestais indígenas. Em substituição às cooperativas, as associações e organizações ${ }^{9}$ indígenas pas-

vel pela organização de grande quantidade dos livros da Coleção Autoria Indígena, atualmente faz parte do conselho diretor da instituição e dá aulas de língua portuguesa o nos cursos de formação de AAFIs.

8 Causado, em parte, pelas políticas do governo federal brasileiro, "dada a acentuada queda de preço do produto, o fechamento das usinas de beneficiamento da borracha e a incerteza que passou a marcar o mercado da borracha natural" (AQUINO, IGLESIAS In CUNHA, ALMEIDA, 2002, p. 154).

9 Segundo dados do portal Povos Indígenas do Brasil, existem 9 associações e organizações kaxinawá atualmente atuando no estado do Acre (ISA, 2018, disponível em https:// pib.socioambiental.org/pt/Organizações_indígenas, acesso em janeiro de 2020).

Figura 7: Páginas do miolo de Huni Meka (CPI-AC, 2007) com registros da pesquisa realizada para a produção do livro e do CD que o acompanha. Fonte: Pesquisa de campo, Paiva (2019) 


\begin{tabular}{|c|c|c|c|c|c|c|}
\hline NOME DA TI & EXT. (HA) & SITUAÇÃO & MUNICÍPIO & Povo(s) & FAMÍLIA LING. & POP. \\
\hline & & & MAN. URBANO & KAXINAWÁ E & PANO & \\
\hline ALTO RIO PURUS & 263.130 & REG. & E STA. ROSA & KULINA & E ARAWA & 5434 \\
\hline IGARAPÉ DO CAUCHO & 12.317 & REG. & TARAUACÁ & KAXINAWÁ & PANO & 747 \\
\hline KATUKINA / & & & & KAXINAWÁ E & & \\
\hline KAXINAWÁ & 23.474 & REG. & FEIJÓ & SHANENAWA & PANO & 2.228 \\
\hline KAXINAWÁ / ASHANINKA DO & & & MARECHAL & ASHANINKA E & ARUAKE & \\
\hline RIO BREU & 31.277 & REG. & THAUMATURGO & KAXINAWÁ & PANO & 767 \\
\hline \multicolumn{7}{|l|}{ KAXINAWÁ COLÔNIA } \\
\hline VINTE E SETE & 305 & REG. & TARAUACÁ & KAXINAWÁ & PANO & 214 \\
\hline \multicolumn{7}{|l|}{ KAXINAWÁ DA PRAIA } \\
\hline DO CARAPANÃ & 60.698 & REG. & TARAUACÁ & KAXINAWÁ & PANO & 873 \\
\hline \multicolumn{7}{|l|}{ KAXINAWÁ DO } \\
\hline BAIXO RIO JORDÃO & 8.726 & REG. & JORDÃO & KAXINAWÁ & PANO & 664 \\
\hline \multicolumn{7}{|l|}{ KAXINAWÁ DO } \\
\hline RIO HUMAITÁ & 127.383 & REG. & FEIJÓ & KAXINAWÁ & PANO & 423 \\
\hline \multicolumn{7}{|l|}{ KAXINAWÁ DO } \\
\hline RIO JORDÃO & 87.293 & REG. & JORDÃO & KAXINAWÁ & PANO & 1896 \\
\hline \multicolumn{7}{|l|}{ KAXINAWÁ } \\
\hline NOVA OLINDA & 27.533 & REG. & FEIJÓ & KAXINAWÁ & PANO & 337 \\
\hline KAXINAWÁ SERINGAL & & EM & & & & \\
\hline CURRALINHO & - & ESTUDO & FEIJÓ & KAXINAWÁ & PANO & 215 \\
\hline \multicolumn{7}{|l|}{ KAXINAWÁ SERINGAL } \\
\hline INDEPENDÊNCIA & 11.584 & REG. & JORDÃO & KAXINAWÁ & PANO & 415 \\
\hline
\end{tabular}

Tabela 1. Terras Indígenas habitadas pelos Kaxinawá no Acre. Abreviações: ext.: extensão; reg.: regularizada; família ling.: família linguística; pop.: população.

Fonte: CPI-AC, 2019. saram a ter papel fundamental nas tomadas de decisões coletivas no que diz respeito a articulações econômicas, políticas e sociais, exercendo, também, o papel de representação das comunidades frente aos poderes públicos e organizações da sociedade civil estaduais, nacionais e internacionais (Ibid.).

Nos últimos anos, a prioridade tem sido dada pelas associações Huni Kuĩ a projetos de valorização da cultura. Além da promoção de rituais de katxanawa (para a fertilidade dos legumes) e de nixpupima (rito de passagem de meninos e meninas, também chamado de "batismo"), têm construído centros culturais e cupixauas ${ }^{10}$, registrando mitos, cantos e técnicas artesanais, resgatado práticas medicinais e incentivado a produção e a comercialização de artesanato. (KAXINAWÁ, IGLESIAS, 2010, p. 77)

Muitas experiências de autoria derivam dos diversos projetos artísticos e de pesquisa produzidos pelos Kaxinawá, seja através do registro de mitos, de pesquisas relacionadas à medicina tradicional, ao levantamento da fauna e da flora, das técnicas tradicionais de produção de artesanato, caça e pesca, da gravação em áudio, vídeo e por escrito de cantos ritualísticos, da produção de filmes, vídeos e obras de arte, entre diversos outros projetos pelos quais já receberam inúmeros prêmios e são internacionalmente reconhecidos.

10 Grandes construções tradicionais indígenas feitas de palha. O termo é comum a várias etnias nawa. 


\subsection{A história da CPI-AC}

Pertencemos a uma geração de ONGs surgida da atmosfera densa da pré-anistia, de uma vontade de democratização e transformação do país. Naquele tempo, quando os povos indígenas não eram fonte fácil de notícia, um grupo de acreanos, liderados por um antropólogo, filhos de seringueiros, jornalistas, artistas, ajudaram a construir a ponte de uma certa passagem. As sociedades indígenas do Acre e Sudoeste do Amazonas - Kaxinawá, Apurinã, Katukina, Manchineri, Yawanawá, Jaminawa, Kulina, Asheninka, Poyanawa, Nukini, Shawadawa, Kaxari, Shanenawa, Jamandi - foram conquistando espaços nas cidades, nos países e no mundo. (MONTE, SENA, et al., 2001, p. 4)

Em meados da década de 1970, a pressão exercida pelas primeiras lideranças indígenas do estado impulsiona a realização de uma pesquisa de reconhecimento dos indígenas habitantes dos vales dos rios Purus e Juruá (em sua maioria, kaxinawás) patrocinada pela FUNAI. Em 1975, Terri Vale Aquino faz sua primeira viagem para esse território, com o intuito de realizar os levantamentos necessários para a compreensão da situação da população indígena daquela região. Três anos depois, as assessoras Maria Conceição Maia de Oliveira (Concita), Keilah Diniz e Maria Djacira Maia de Oliveira (Dedê Maia) realizam, a convite de Terri, viagens de assessoria educacional intituladas "Atividades de Desenvolvimento de Comunidade e Educação Indígena". O projeto, já desvinculado à FUNAI, era voltado para a alfabetização de "algumas pessoas que estavam ligadas à cantina, havia uma proposta de montar uma cantina ${ }^{11}$, no processo de conquista daquele território ali, antes de se chamarem cooperativas, era cantinas" (AQUINO, 2019) e foi realizado a partir da angariação de fundos pela própria equipe.

Os meticulosos relatos produzidos pelas assessoras em campo deram continuidade aos primeiros levantamentos etnográficos e geográficos realizados no projeto patrocinado pela FUNAI nos anos anteriores. Registram, além de dados demográficos sobre a população indígena habitante das colocações e seringais, o complexo cenário social, político e econômico no qual a mesma estava inserida. Ainda vivendo em grande parte subordinados aos seringalistas, sua mão de obra era explorada, suas condições de saúde e subsistência eram precárias e práticas tais como castigos físicos eram comumente empregadas como punição àqueles que manifestavam apoio às recentes iniciativas indigenistas.

Monte (2008) ressalta que, ao analisar os relatórios e diários decorrentes dessas primeiras viagens de assessoria, já é possível encontrar rascunhos das que seriam as principais frentes de atuação da CPI-AC, tais como a escolarização, o cooperativismo, a saúde e os aspectos culturais diversos (língua, artesanato, relatos) que estão diretamente conectados à compreensão de um conceito de "indianidade" que estivesse mais atrelado às reais condições e demandas dos povos indígenas do Acre.

A necessidade de institucionalizar essas iniciativas também é latente nesse primeiro momento - como forma de fornecer algum tipo de respaldo profissional e político para os assessores, vítimas de ameaças e técnicas diversas de intimidação - e culmina com a formalização da Comissão Pró-índio do Acre em 1979, após uma viagem que Terri realiza com lideran- 
Figura 8: Linha do tempo: a história da CPI-AC. Fonte: Adaptação da autora a partir de Monte (1996, 2008); e Monte \& Sena (et al., 2001) ças indígenas para o Rio de Janeiro, onde os mesmos conhecem a Comissão Pró-índio do Rio de Janeiro, cujo estatuto serviria de base para a concepção de um estatuto próprio.

Ao iniciar sua atuação no processo de demarcação das terras indígenas e no apoio às cooperativas, o objetivo maior da CPI-AC era propiciar a obtenção da autonomia necessária para que as populações indígenas pudessem gerenciar seus territórios e certificar a obtenção e manutenção de direitos. No início da década de 1980, a partir da demanda pelo ensino de português e matemática colocadas pelas lideranças kaxinawá (MONTE, 1996), tem-se início o projeto de educação indígena diferenciada para formação de professores e agentes de saúde indígenas que se tornaria definidor da instituição e dos caminhos futuros para sua atuação.

A Comissão Pró-Índio teve pelo menos duas fases: a fase heroica, essa coisa dos anos 70, ligada ao jornal Varadouro, às denúncias com relação à invasão das terras indígenas, às primeiras organizações de representação dos índios, até uma segunda fase, em que a Comissão Pró-Índio reestrutura seu trabalho com projetos mais definidos, contínuos. (ALVES In MONTE, SENA, et al., 2001, p.23)

O projeto de educação expande-se durante as décadas de 1980 e 1990, ganhando novas dimensões com a aquisição de um grande terreno localizado na área rural de Rio Branco, onde a nova sede da instituição foi construída. Além de um espaço específico destinado aos cursos de formação de professores, o reflorestamento do "sítio", como é comumente chamado pela equipe, foi um exercício prático para a configuração do curso de Agentes Agroflorestais Indígenas, iniciado em 1996 e que ocorre até os dias atuais. Em 1997 o Centro de Formação dos Povos da Floresta, seu nome oficial, foi reconhecido como Escola de Formação de Professores Indígenas pela Secretaria Estadual de Educação, tornando-se a primeira Escola Indígena do Acre e do Brasil.

Trata-se de uma área rural de 26 hectares, de posse da CPI-AC desde 1994, cuja função é servir de espaço pedagógico para a formação de jovens de várias etnias como professores, agentes de saúde e agentes agroflorestais, em programas desenvolvidos pela CPI-AC. O Centro é registrado na Coordenadoria de Registro e Inspeção Es-

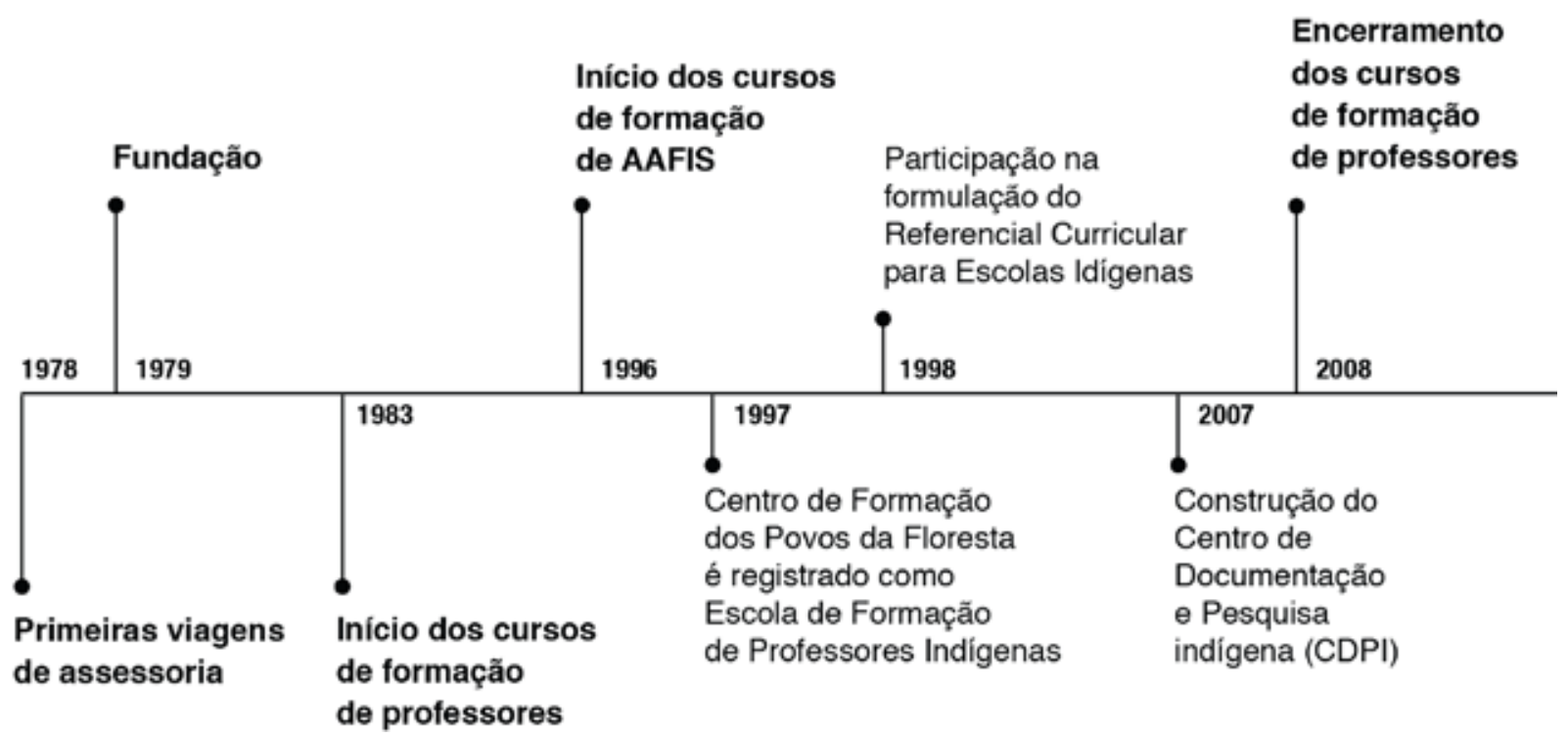




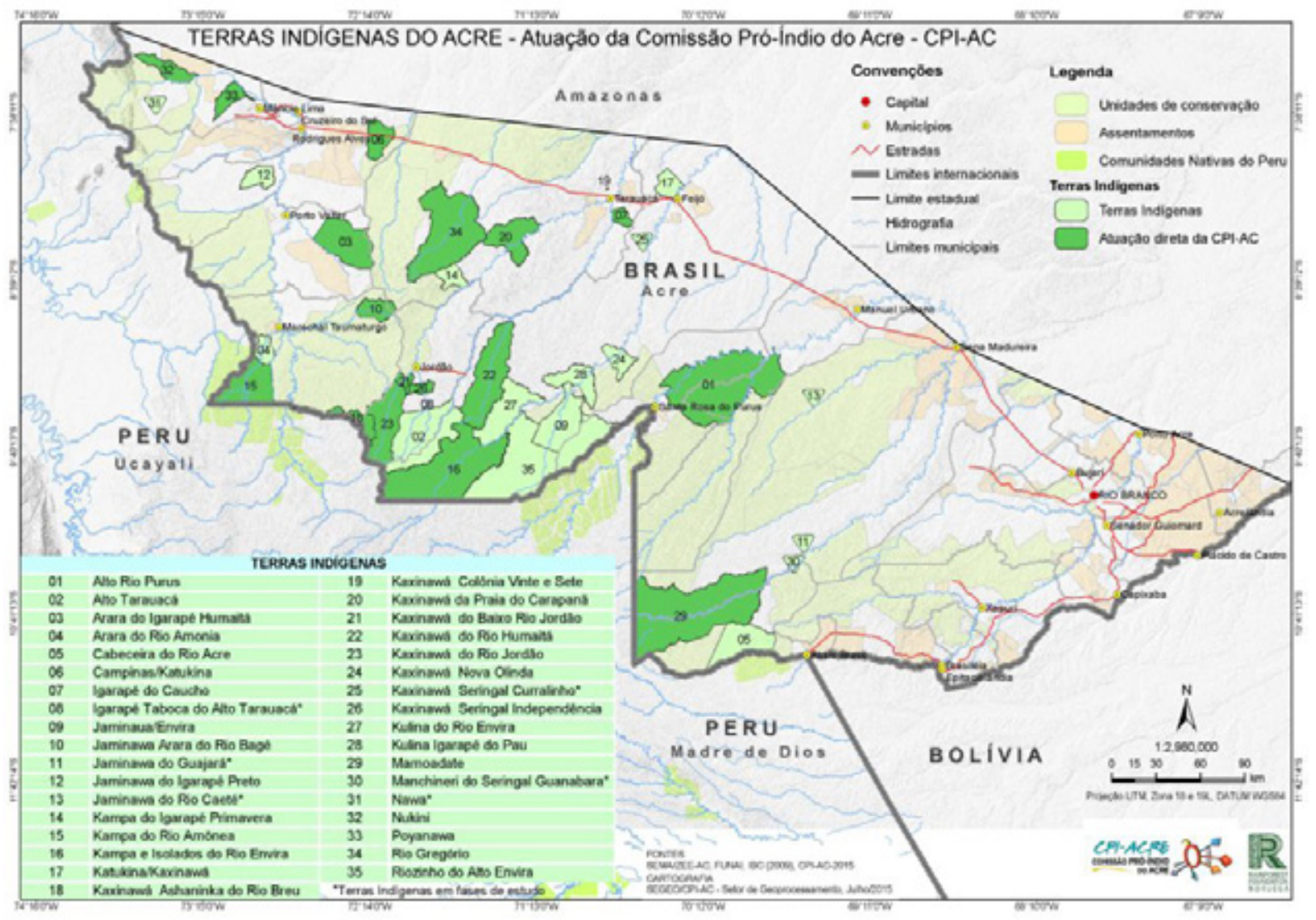

colar, CORINES como a primeira Escola de Professores Indígenas do Estado (e do país) no livro n-03, cadastro 035/97 e folha n 35. (MONTE, SENA et al., 2001, p. 48)

As constantes assembleias, seminários e grupos de trabalho paulatinamente estabeleceram uma "cultura de projetos" (ALVES In MONTE, SENA, et al. 2001, p.24) que, juntamente com a continuidade dos cursos de formação, propicia a criação de organizações indígenas diversas, das quais se destacam a Organização de Professores Indígenas do Acre (OPIAC) e a Associação do Movimento dos Agentes Agroflorestais Indígenas do Acre (AMAAIAC).

Foi nos cursos de formação de professores que tivemos a visão de começar a fundar o movimento indígena, as associações e nossas próprias organizações locais, de acordo com a realidade de cada povo. (...) Através de nossas próprias organizações, continuaremos conquistando nossos desejos, principalmente o de sermos povos indígenas sem sofrer discriminação. (KAXINAWÁ et al., 199-, p. 133)

Em entrevista, o atual vice-coordenador da OPIAC, Eldo Gomes Shamenawa, relata que a OPIAC é constituída em um momento em que se percebe a necessidade e importância de um canal institucional específico para apresentar demandas e necessidades da educação indígena ao governos estaduais e federais, a partir da atuação específica indígena, mesmo que ainda assumindo outras ONGs, como a CPI-AC, como parceiras. Segundo dados do Instituto Socioambiental existem atualmente 55 associações e organizações indígenas no estado do Acre atualmente (ISA, 2018, acesso em dezembro de 2019).

Claro que no passado a gente era tutelado, hoje não, a gente já tem essa autonomia de decidir aquilo que é nosso, a CPI é parceira, o parceiro é parceiro, mas para mandar
Figura 9: Terras indígenas do Acre. Fonte: Setor de Geoprocessamento da CPI-AC, 2015. Disponivel em: <http:// cpiacre.org.br/conteudo/ terras-indigenas-doacre/>. Acesso em janeiro de 2020. 
mesmo, opinar, jamais. Então a gente tem essa autonomia, quando eu falo de parceria é isso, vamos contribuir. A ideia de criar essas associações é exatamente isso, aumentar a autonomia. (GOMES SHAMENAWA, 2019)

As viagens de assessoria também continuam acontecendo e guiando a atuação da CPI-AC em diversas frentes, de acordo com as demandas, observações e retornos coletados em campo. Dessa forma, foram e são desenvolvidos projetos de formação de professores, agentes de saúde, além de planos de gestão territorial e ambiental de terras indígenas. Também foram criados o Grupo de Trabalho Transfronteiriço (GTT) e o Centro de Documentação dos Povos da Floresta, sem mencionar a organização de eventos e encontros culturais, exposições entre outros. A variedade de atividades e possibilidades de engajamento fez com que a atuação da entidade aumentasse paulatinamente.

O Estado do Acre possui, atualmente, uma população indígena estimada em cerca de 17 mil pessoas, distribuídas em 36 Terras Indígenas (já reconhecidas pelo governo federal, mas em diferentes etapas do processo de regularização), correspondendo a 15 etnias: Kaxinawá / Huni Kuĩ, Madija / Kulina, Shawadawa / Arara, Jaminawa, Manchineri / Manchineru, Katukina, Ashaninka, Shanenawa, Nawa, Kuntanawa, Nukini, Puyanawa e outros 3 povos isolados. Segundo dados da própria instituição, a "CPI-Acre atua em 17 terras indígenas e uma unidade de conservação, onde vivem 11 povos indígenas com população geral de 9.762. Deste total, a CPI-Acre alcança direta e indiretamente uma população de 8.891" (CPI-AC, s/ d.).

\subsection{Os Cursos de Formação de Professores Indígena}

O cenário prévio à realização dos primeiros "Cursos de Formação de Professores Indígenas" pela CPI-AC era composto por iniciativas pontuais e desarticuladas de alfabetização indígena, segundo Gleyson Teixeira ${ }^{12}$, coordenador executivo atual da CPI-AC, "escolas promovidas por alguns patrões seringalistas, sem nenhuma perspectiva de valorização cultural" (TEIXEIRA, 2018), cujo interesse na alfabetização indígena estava diretamente relacionado ao rendimento econômico dos seringais; e o movimento missionário, principalmente através do projeto Novas Tribos do Brasil, com o apoio do SIL (Summer Institute of Linguistics ou Sociedade Internacional de Linguística).

Teve uma outra experiência, que foi a experiência dos missionários, principalmente "Novas tribos do Brasil", com apoio do SIL - Instituto Lingüístico de Verão - e, nesses casos, especificamente, houve sim a utilização muito da língua indígena, a produção de materiais relacionados à saúde, ao próprio registro de narrativas místicas, historias importantes pra cada povo. Mas, também, sabemos que esse respeito à língua indígena não era acompanhado, por exemplo, de um respeito às práticas religiosas. Porque há um tom missionário muito forte dessas agências evangélicas, sobretudo norte-americanas. Então, a experiência Novas Tribos do Brasil se estabeleceu aqui no Acre formando alguns núcleos,

12 Gleyson Teixeira é cientista social, atual Coordenador Executivo e de Representação Institucional e diretor do Programa de Educação e Pesquisa Indígena da CPI-AC, de cuja equipe faz parte desde o final da década de 1990. 
pequenas experiências, também, de escolas, mas não de escolas que lutavam para ser reconhecidas pelo estado. Então tem, ali, uma ou outra iniciativa, em seringais, muito antes da demarcação das terras.

Mas aí muito antes disso [referindo-se à constituição de 1988]. Eu tô falando, assim, no caso da produção de materiais didáticos, encapados, ali, incentivados pelos missionários. Tinham interesse de inserir isso no processo, mesmo, de registro das línguas e, também, com isso, viabilizar formas de tradução dos textos bíblicos para as línguas nativas, línguas maternas, desses povos. (TEIXEIRA, 2018)

No começo da década de 1980 , com o progresso do cenário de articulação política e os avanços lentamente alcançados pelas primeiras lideranças indígenas do estado - a configuração das cooperativas indígenas, o início da atuação da FUNAI e, consequentemente, do processo de demarcação das terras indígenas - a demanda por educação e saúde entra em pauta, já com a clara proposição de uma formação de professores e agentes de saúde indígena, ao invés de apenas direcionar não-indígenas para estas funções nas comunidades.

\begin{abstract}
Se o senhor mandar alguém da FUNAI de Brasília, ele vai passar pouco tempo na nossa aldeia. Logo ele vai querer voltar para a terra dele. Assim, nós vamos ficar de novo sem professor. Quem não aprendeu, fica sem aprender. Quem aprendeu alguma coisa, aprendeu bem pouquinho. Agora, se fosse como em certas aldeias tudo bem. Tem povo que perdeu até a sua própria língua por causa dos massacres. Só fala português. Lá no Acre é muita diferença. Nós vivemos no fim do mundo. Muita gente se criou lá mesmo na aldeia, nunca saiu, e não fala português. Outros falam muito ruim. Era bom se a FUNAI e as entidades ajudassem a preparar os próprios índios para lecionar e para fazer atendimento de saúde. Assim eles vão falar na nossa própria língua e traduzir para o resto do povo entender. (KAXINAWÁ, 199-, p. 128-9)
\end{abstract}

Em fevereiro de 1983 acontece o "I Curso de Formação de Professores e Agentes de Saúde Indígenas", concebido e realizado pela recém-formada "equipe de educação" da CPI-AC (MONTE, 1996). "Além de preparar os monitores para que eles pudessem administrar as cooperativas locais, o propósito do curso era que eles também pudessem ensinar aos demais, impulsionando as escolas comunitárias" (CPI-AC, 2018). Para além da alfabetização, o primeiro curso foi, especialmente, um espaço de encontro que propiciou a articulação das lideranças presentes, muitas das quais não conheciam ainda seus "parentes" de outras etnias do estado (MONTE, 1996).

O seringalista escravizava muito o índio porque ninguém sabia ler e nem escrever. Para trabalhar na nossa cooperativa, os próprios índios tinham que fazer a contabilidade do movimento de mercadorias e de borracha. Por isso, os índios precisavam ter escolas nas aldeias. (KAXINAWÁ et al., 199-, p. 128)

O desafio era grande: além de alfabetizar formalmente os professores (alguns dos quais não falavam, ainda, o português), era necessário criar o currículo e o planejamento didático das "Escolas da Floresta", de modo a estimular a formação dos futuros alunos a partir de uma combinação das 
"experiências pedagógicas singulares, construídas criativamente por cada professor índio" e da manutenção de uma "tensão dialética entre a história singular de cada comunidade escolar e a história social do movimento indígena" (MONTE, 1996, p. 4).

"É no sentido de uma formulação curricular progressivamente complexa e completa, metodologicamente construída de forma participativa, que continuamos agindo como educadores" (Ibid., p. 8). Tal proposta participativa ganha uma dimensão material a partir da produção de materiais didáticos específicos, que pudessem acompanhar de maneira adequada a proposta didática em construção (Ibid.).

Uma série de viagens de assessoria foram realizadas após o primeiro curso, e durante toda a década de 1980, para a distribuição das cartilhas, acompanhamento e registro do início das atividades didáticas dos "monitores indígenas", como eram então chamados os vinte e cinco jovens de seis etnias que haviam participado do primeiro curso de formação promovido pela CPI-AC. Nos relatos feitos em campo pelos assessores, percebem-se mudanças importantes no cenário econômico, político e cultural retratado nas primeiras viagens de assessoria, realizadas na década de 1970. O início do processo de demarcação das terras indígenas e a configuração de novas alianças, cooperativas e associações propiciam o surgimento da noção de autonomia por parte dos povos indígenas, como coloca Monte, "Funções educativas, administrativas e políticas, antes promovidas pelos funcionários dos Estados ou pelas igrejas, seriam disputadas como funções próprias de cada comunidade" (MONTE, 2008, p. 57). Esse movimento encontrava-se diretamente atrelado à necessidade de uma formação que pudesse fornecer não apenas o domínio de português e matemática, mas também de um posicionamento político-cultural próprio enquanto indígena.

Os "monitores indígenas", impulsionadores e gestores
das escolas comunitárias, eram os jovens que, doravan-
te, se responsabilizaram pela gestão da educação escolar
indígena e pela construção e realização de suas pedago-
gias. Em uma série de viagens, testemunhava-se a im-
plantação e o funcionamento da nova escola indígena,
sob a batuta de jovens monitores indígenas e com o apoio
dos assessores. Em Rio Branco, eles e elas participariam
como estudantes, por dois a três meses anuais, de cursos
intensivos de formação profissional e educação básica
que funcionaram sistemática e continuamente a partir
desse primeiro. (MONTE, 2008, p. 58)

Os assessores passaram a observar que as cartilhas e o processo de "concepção de autoria" decorrente de sua produção eram um dos grandes diferenciais da concepção pedagógica dos monitores e escolas indígenas, e são muitos os relatos do entusiasmo geral que o material impresso causava tanto entre os mais novos quanto entre os mais velhos das diversas comunidades indígenas. Debates e posicionamentos conflitivos passaram a acontecer como parte do processo de implementação das escolas, e discutia-se, especialmente, como conciliar o modelo tradicional de ensino e escola, em alguns casos já experienciado pelos indígenas nas iniciativas de educação e alfabetização realizadas por órgãos da igreja católica (como o Conselho Indigenista Missionário e as Missões Novas Tribos) ou mesmo nas escolas públicas estaduais. Intentava-se "fomentar pedagogias indígenas" e "implementar, sem impor, as desejadas 'didáticas diferenciadas', diferenciando a nova prática das anteriores" (MONTE, 2008, p. 61). 
Tal processo manteve-se em constante transformação e discussão envolvendo, de um lado, questões teóricas, relacionadas à concepção do conceito da educação indígena diferenciada e, de outro, questões práticas relacionadas ao dia-a-dia das escolas indígenas, os locais onde as mesmas se estabeleceriam, seu calendário e a adequação ao cotidiano das comunidades. Da mesma forma que os monitores em formação se aproximavam dos métodos educacionais da escola tradicional não-indígena, os assessores aprendiam os modos de repasse de conhecimentos tradicionais daquelas populações, como conta Dedê Maia, que participou das primeiras viagens de assessoria e foi uma das educadoras do primeiro curso de formação, em entrevista:

\begin{abstract}
Olha, o que eu pude observar, na minha experiência como educadora, a gente - como eu te falei, eu, logo no início, e isso depois foi, de certa forma, pensado dentro do programa também - tinha toda uma forma de aplicar aquela técnica, vamos dizer assim, para que eles pudessem adquirir a técnica da escrita, da leitura, um método. Nós levamos pra discussão aquilo tudo que o Paulo Freire apresentava. Nessa época, eu seguia à risca. Quando eu fui para o Humaitá, eu me deparei com uma outra história, que estava se revelando ali pra mim. Eles não queriam discutir os problemas, eles já sabiam que tinham todos aqueles problemas. Eles já sabiam que eram roubados pelo patrão. Eu via como eles cantavam, como eles apendiam a cantar, era repetindo. $O$ velho cantava, ele repetia, o velho cantava, ele repetia. E aí eu vi que dentro da alfabetização, quando a gente começou a trabalhar com os vocábulos e tal, eu via assim: os meninos repetindo, tentando decorar aquilo. Eu falei, gente, o caminho é mais ou menos por aí. Não adianta eu ficar aqui querendo discutir coisas para avaliar, contextualizar e aquela coisa toda. Então eles foram desenhando pra gente como era que eles aprendiam as coisas. Como eles podiam aprender aquela técnica da escrita e da leitura, mesmo. (MAIA, 2019)
\end{abstract}

A captação de recursos realizada pela CPI-AC possibilitou a impressão dos títulos, assim como a continuidade dos cursos, que passaram a acontecer anualmente. Em 1985, novas disciplinas, como geografia e história, foram incluídas na formação, que antes abrangia apenas português e matemática (MONTE, 1996). Foi também durante a década de 1980 que os cursos passaram a abranger o estudo específico das línguas indígenas, com cartilhas de alfabetização e materiais bilíngues ou exclusivamente em língua indígena.

Nos anos seguintes a expansão dos cursos continuou, com a formação de agentes de saúde em cursos específicos (iniciados em 1986) e a consolidação dos cursos de formação de professores. Em 1992 e 1993 esse trabalho deu importantes frutos: em 1992 ocorre o primeiro concurso público para professores indígenas e em 1993 o Conselho Estadual de Educação do Acre aprova (Parecer 171/93) a primeira Proposta Curricular para as Escolas Indígenas do Estado do Acre e Sudoeste do Amazonas voltada para o primeiro segmento do Ensino Fundamental, cuja proposta curricular fora sistematizada pela CPI-AC com base na experiência de dez anos do Projeto de Autoria (MONTE, SENA et al., 2001).

Em 1996 a CPI-AC, a partir de novas demandas apresentadas pelas lideranças indígenas do estado, passa a oferecer cursos para a formação de Agentes Agroflorestais Indígenas - AAFIs, uma nova categoria formativa e 
de atuação profissional que diz respeito ao manejo e produção sustentável de insumos ambientais, e busca fornecer ferramentas para a gestão e fiscalização territorial das terras indígenas.

E foi justamente a partir do interesse pelo trabalho de plantação de árvores frutíferas iniciado no Centro, e das ações de saúde relativas à diversificação alimentar, que teve início o programa de formação dos Agentes Agroflorestais (AAFI), com o apoio do Ministério do Meio Ambiente, PPG7 (Programa de Proteção as Florestas Tropicais), pelo PD/A (Sub-Programa de Projetos Demonstrativos).

(...) Talvez mais importante que os dados e resultados quantitativos, é o desenvolvimento de uma nova proposta de gestão territorial das áreas indígenas, tendo no agente agroflorestal seu grande motivador, junto aos professores e lideranças. Os AAFIs vêm cumprindo um papel educativo e de agentes fiscalizadores das terras indígenas. (MONTE, SENA et al., 2001, p. 64)

A formação dos AAFIs segue o modelo desenvolvido nos cursos de formação de professores - nos quais, inclusive, já se tratava, de modo transversal, de questões produtivas, alimentares, de ocupação territorial etc - mas envolviam, também, oficinas realizadas in loco nas comunidades indígenas, assim como no Centro de Formação de Professores Indígenas na sede da instituição. Aqueles já formados nos cursos passavam, então, a atuar nas oficinas em outras terras indígenas. Muitas viagens estaduais, nacionais e internacionais foram facilitadas e incentivadas pela CPI-AC, como parte dos variados projetos executados. O Centro de Formação também funciona como um espaço de constante articulação, por atrair pesquisadores, professores e estudantes, indígenas e não indígenas. $O$ contato entre as etnias diversas e o compartilhamento de conhecimentos culturais e técnicos, assim como os intercâmbios realizados, são características importantes do posicionamento didático dos cursos realizados pela instituição.

Para mim, como professor, educador, até hoje o nosso mundo, o mundo Asheninka, é muito pequeno em população, mas, nossa história é muito grande. Eu sou um professor lá, tenho condições de conversar com todas as pessoas da aldeia. Todas as pessoas da aldeia podem me ouvir como professor. Não é o Brasil, é o mundo que é muito grande. Um professor não pode dar conta de conversar com todas as pessoas. Como representante da minha aldeia, professor e educador, é importante conhecer outros povos, outros países, outros continentes, que têm diversas culturas. E, já viajei bastante, mas, moro na minha comunidade. O que aprendo, o que vejo, o que descubro, falo para minha comunidade. (Depoimento de Isaac Asheninka In MONTE, SENA et al., 2001, p. 73)

Um outro ponto interessante da formação dos AAFIs é o módulo Artes e Ofícios, parte do currículo do curso em que são produzidas esculturas, pinturas e peças de mobiliário. O conceito geral dessas oficinas (como também são chamadas) é trabalhar a partir da reutilização de sobras de madeira - por exemplo, as peças desprezadas pelas serrarias e que acabam servindo como lenha para as olarias - assim como de árvores e galhos que caem naturalmente das árvores no terreno do Centro de Formação, como forma de agregar valor estético, cultural e econômico a uma matéria prima que seria 
descartada. Após o processo de configuração formal, as peças são finalizadas com vernizes e tintas naturais - com o vasto uso de jenipapo, urucum, carvão, óleos vegetais, entre outros - produzidas pelos alunos. O estímulo para a criação das obras deriva das tradições mitológicas e iconográficas de cada etnia, e cada aluno, antes de iniciar o trabalho prático de esculpir a madeira, registra em texto e desenhos a história na qual se inspirou. Outra motivação importante é a possibilidade de venda das peças, propiciando uma alternativa interessante para a geração de renda nas comunidades. Exposições diversas foram e são, até hoje, realizadas com as peças decorrentes das oficinas, que incluem bancos, cadeiras, poltronas, mesas, bandejas, pratos, esculturas e, na formação de 2019 , telas pintadas sob a orientação de Isaías Sales Ibã, um dos fundadores do coletivo MAHKU (Movimento dos Artistas Huni Kuĩ), professor e artista plástico formado no primeiro curso de formação de professores, em 1983.

\begin{abstract}
"Eu comecei pegando a tora de pau d'arco que tinha rolado do açude. Eu comecei pegando na machadinha, formão, giz e comecei a marcar com giz na tora de pau d'arco pensando para formar uma mulher. Essa mulher antigamente ela era encantada na história do índio, ela era cobra e virava mulher. Comecei desenhando no pau bruto, para depois fazer a forma da cara da mulher. Eu trabalhei 4 dias pra fazer essa forma. Quando terminei virou cara de mulher, comecei a pintar com carvão a cabeça dela para virar cabelo e ela pintei com urucum e jenipapo. Esse trabalho eu achei muito importante pra fazer no meu estudo de Agente Agroflorestal. A gente tem que pensar as coisas para fazer daqui pra frente. Eu estou pensando para aprender mais coisas para ajudar esse trabalho na minha cultura." - AAFI Francisco Melo Ibã Kaxinawá. (GAVAZZI, 2017, p. 76)
\end{abstract}

Em 1998 o Ministério da Educação publica o Referencial Curricular para Escolas Indígenas - RCNE/I. "O RCNE/I foi elaborado, pela primeira vez no país, por iniciativa do MEC, em sua nova atribuição de coordenação da educação para as populações indígenas" (MONTE, In MONTE, SENA et al., 2001, p. 51). Nietta Lindemberg Monte, antropóloga e educadora que chefiou o projeto de educação indígena da CPI-AC fez parte da equipe responsável pela elaboração do Referencial. Segundo o relato de Nietta, o propósito geral era de "reorientar as fragmentadas e, às vezes, díspares, ações públicas e privadas da educação escolar indígena" (Ibid.). Joaquim Maná Kaxinawá, professor e pesquisador indígena formado nos cursos oferecidos pela CPI-AC, também integrava a equipe. Em texto onde o mesmo analisa a proposta desenvolvida, ele ressalta que, apesar de configurar-se enquanto importante conquista no árduo caminho para a obtenção e garantia de uma educação indígena diferenciada e de qualidade, o Referencial deve ser complementado por uma compreensão e colaboração dos órgãos públicos nacionais e estaduais a respeito das "situações de trabalho exigidas pelos professores e educadores diante das dificuldades que estiverem passando, como sempre passaram nesses anos anteriores" (KAXINAWÁ, In MONTE, SENA et al., 2001, p. 53).

Este documento foi um grande trabalho a que as organizações não-governamentais e os professores indígenas se dedicaram nos últimos anos, após cinco séculos de uma educação não diferenciada. Ao longo desses quinhentos anos, os povos indígenas nunca tiveram uma proposta exclusiva para sua educação escolar, de forma diferenciada, posta em prática pelos programas dos governos fede- 
ral, estadual e municipal. Estas propostas têm se voltado, nesses últimos anos do século XX, para a realidade e valorização das heranças culturais dos povos indígenas. Isso significa que não é mais aquela escola que os povos indígenas receberam desde o início dos missionários e do Governo, uma escola assimiladora das culturas indígenas do Brasil (...) em 1996, já existiam 86 escolas indígenas e 111 professores, distribuídos em 11 municípios do Acre. Então, são estas escolas e professores que estão agora amparados e contemplados pelo RCNE/I, como também estão assegurados nos artigos 231 e 232 da Constituição Federal e da Nova LDB, nos artigos 78 e $79^{13}$. (KAXINAWÁ In MONTE, SENA et al., 2001, p. 53)

Em 2003, já eram mais de 150 professores formados no nível médio, e mais de uma centena de escolas implantadas nas comunidades indígenas (MONTE, SENA et al., 2001). O ciclo iniciado no começo da década de 80, além de dar importantes frutos políticos e sociais, já completava mais de uma volta em si mesmo com a publicação de livros que analisam e aprimoram a discussão do projeto pedagógico, em constante desenvolvimento pelos professores (MONTE, 2003), tais como o Caderno de Reflexão do Professor Indígena, lançado em 2005. A continuidade da formação dos professores e das viagens de assessoria foi fundamental para que as análises sobre as práticas escolares e culturais indígenas pudessem ser aprofundadas, em estudos de "etnografia da sala de aula" (MONTE, 2008). Ficava cada vez mais claro o imprescindível papel das práticas culturais tradicionais (cantos, festas, rituais etc) na construção do currículo e da didática indígena.

Além das pesquisas elencadas, a investigação das práticas de medicina tradicional, do artesanato, das músicas, da história oral, com especial atenção para a atualização de versões da história antiga e/ou recente de seu povo e comunidade, deu-se bastante ênfase na continuidade das "etnografias da sala de aula". Estas estavam voltadas à reflexão mais aguda sobre a prática escolar da educa-

13 Conforme consta na Lei de Diretrizes e Bases da Educação: "Lei no 9.394 de 20 de Dezembro de 1996. Estabelece as diretrizes e bases da educação nacional. Art. 78. O Sistema de Ensino da União, com a colaboração das agências federais de fomento à cultura e de assistência aos índios, desenvolverá programas integrados de ensino e pesquisa, para oferta de educação escolar bilingüe e intercultural aos povos indígenas, com os seguintes objetivos: I - proporcionar aos índios, suas comunidades e povos, a recuperação de suas memórias históricas; a reafirmação de suas identidades étnicas; a valorização de suas línguas e ciências; II - garantir aos índios, suas comunidades e povos, o acesso às informações, conhecimentos técnicos e científicos da sociedade nacional e demais sociedades indígenas e não-índias.

Art. 79. A União apoiará técnica e financeiramente os sistemas de ensino no provimento da educação intercultural às comunidades indígenas, desenvolvendo programas integrados de ensino e pesquisa. $\$ 1^{\circ}$ Os programas serão planejados com audiência das comunidades indígenas. $\$ 2{ }^{\circ}$ Os programas a que se refere este artigo, incluídos nos Planos Nacionais de Educação, terão os seguintes objetivos: I - fortalecer as práticas sócio-culturais e a língua materna de cada comunidade indígena; II - manter programas de formação de pessoal especializado, destinado à educação escolar nas comunidades indígenas; III - desenvolver currículos e programas específicos, neles incluindo os conteúdos culturais correspondentes às respectivas comunidades; IV - elaborar e publicar sistematicamente material didático específico e diferenciado. § 30 No que se refere à educação superior, sem prejuízo de outras ações, o atendimento aos povos indígenas efetivar-se-á, nas universidades públicas e privadas, mediante a oferta de ensino e de assistência estudantil, assim como de estímulo à pesquisa e desenvolvimento de programas especiais. (Incluído pela Lei $\mathrm{n}^{\circ} 12.416$, de 2011)" (JUSBRASIL, s/ d., acesso em março de 2018). 
ção indígena diferenciada, sob o comando da Organização dos Professores Indígenas (OPIAC), a relação entre manutenção e desenvolvimento das línguas e a escola indígena, o que tem configurado o perfil de especialização em pesquisa dos professores e da assessoria. (MONTE, 2008, p. 166)

A relação entre a realização dos cursos de formação, a confecção da proposta educacional e do material didático próprio, a valorização das práticas culturais tradicionais de cada povo e a busca por uma autonomia política indígena cada vez maior é o aspecto mais mencionado pelos professores nos vários relatos apresentados em uma publicação feita pela instituição em 2001, como se vê a seguir.

Depoimento do professor Isaac Pinhanta Asheninka:

O trabalho mais importante da CPI-AC foi fazer com que os professores reconhecessem seus valores culturais, produzindo seus próprios materiais escritos na língua, fazendo com que o professor faça suas pesquisas, ampliando o conhecimento tradicional de seu povo. (...) E hoje estamos organizados para dentro das secretarias, defendemos nossos direitos na educação. Estamos preparados para, junto com as lideranças, defendermos nossa terra. Estamos preparados até para ajudar os professores não índios. (MONTE, SENA, et al., 2001, p.30)

Alguns povos já estão voltando à sua realidade, ao seu modo de vida. Alguns já estão buscando história muito antiga. Outros já estão pesquisando a língua, elaborando materiais na língua, procurando sua própria geografia, pensando em como criar uma matemática, pensando na ciência, o conhecimento que tem da floresta, de como que a gente pode trabalhar, como que a gente pode melhorar a comunidade. (...) Esse é o ponto fundamental que a CPI-AC está dando para os professores: fazer com que o professor seja criativo, começando a pensar junto com a comunidade a abrir um caminho novo para a vida que seja dentro de sua cultura. (Ibid., p.32)

Depoimento do professor Siã Huni Kũ̃:

Este foi o primeiro passo [a participação no primeiro curso de formação] para nós que nem sabíamos falar o português e pudemos fazer o estudo da matemática para tocar nossos negócios na cooperativa, nossa borracha, nossa produção, nossa agricultura, nossa criação. Um produto importante que nós aprendemos para começar a ser independentes para esta vida, que é muito frágil. (Ibid., p.32)

Depoimento de Francisco Pancho Lopes, liderança kaxinawá:

Primeiro nós dependíamos muito do branco, professor branco, saúde do branco. Mas depois que estamos vendo, estudando aqui e acabou que o parente aprendeu ensinar os meninos. Então, primeiro era tudo branco, mas hoje em dia é nosso. Índio mandou os parentes para escola, prefeitura e estado ajudando a escola, para cada comunidade. Cada comunidade tem agente de saúde, tem educação. O índio está lutando para vencer e não é mais dependente do branco. Agora é o índio mesmo. (Ibid., p.30) 
Depoimento de Fernando Yawaná:

A CPI-AC não teve uma visão de escolas dos brancos. Ela respeitou a convivência indígena. $O$ estudo, a formação que recebemos nos ajudou bastante a trabalhar para nossa própria economia, incentivou que nós pudéssemos, como professores, voltar na nossa aldeia e fazer um trabalho que não destruísse a cultura indígena e também conhecesse os dois lados, continuando como povo indígena. (Ibid., p.43)

Os processos de formação continuavam gerando frutos em forma de livros, que, a partir dos anos 2000, passaram a contar com as pesquisas realizadas por professores já formados, somando aspectos mais específicos e culturais às cartilhas de alfabetização e livros didáticos. Construído em 2007, o Centro de Documentação e Pesquisa Indígena (CDPI), localizado na sede da CPI/AC, em Rio Branco, Acre, abriga uma vasta biblioteca e o acervo documental da instituição, possibilitando o acesso desse material aos pesquisadores.

Em 2008 a Secretaria de Estado de Educação assume integralmente a responsabilidade pela execução das ações de Educação Escolar Indígena no estado. Termina, assim, o projeto "Uma experiência de autoria dos índios do Acre", assim como a realização dos Cursos de Formação de Professores Indígenas. Foram 27 cursos realizados no total. Com o encerramento dos cursos de formação de professores, a CPI-AC continua atuando na formação de AAFIs, assessorando os professores e lideranças indígenas e concentrando esforços, especialmente, no apoio à pesquisa linguística, às reinvindicações políticas, e à gestão territorial e ambiental das terras indígenas.

\subsection{Os métodos editoriais da CPI-AC}

Para os professores-autores, a produção de material didático próprio tem muito destaque: "através dos materiais pedagógicos editados pela Comissão Pró-índio na formação dos professores, mostramos que a nossa capacitação tem uma grande vantagem em relação à formação dos professores brancos. Porque, geralmente, a formação dos professores brancos é uma coisa decorada. $\mathrm{E}$, na formação dos professores da CPI-AC é diferente. Os professores se formam fazendo materiais, buscando aquela experiência adquirida na comunidade e passando da parte oral para a parte escrita. E, a partir daí, torna-se mais rico" afirma Adailzo Vinia Yawaná. (MONTE, SENA, et al., 2001, p. 54)

O primeiro livro didático produzido pela CPI-AC partiu da necessidade de desenvolver um material próprio para a - então nascente - atividade de professor indígena. Monte (1994) explica que, apesar de utilizarem uma cartilha já existente para a alfabetização dos professores, no decorrer do curso o material provou-se insuficiente para adequar-se às especificidades das populações indígenas acreanas. Tratava-se da Cartilha Poronga, desenvolvida em 1982 pelo Centro Ecumênico de Documentação e Informação (CEDI) à pedido do Centro de Documentação e Pesquisa da Amazônia (CEDOP/AM), como parte do Projeto Seringueiro, uma iniciativa voltada para a educação básica dos trabalhadores dos seringais. A cartilha se divide em três módulos, o de português, o caderno de matemática e o caderno do 
monitor (CEDI, 1984). No primeiro curso de formação desenvolvido pela CPI-AC utilizou-se, inicialmente, os cadernos de português e matemática, considerados inadequados "à especificidade cultural indígena (mesmo porque ela não foi feita para ou com os índios)" (MONTE, In CABRAL et al. 1987, p. 20). Dessa forma, agregou-se ao processo pedagógico a confecção de um novo material de português, desenvolvido e utilizado pelos professores, e com o qual os mesmos se sentiriam mais confortáveis e autônomos em sua própria sala de aula (MONTE, 1994). No momento do primeiro curso, decidiu-se pela produção do material para a alfabetização em português, considerado mais prioritário pelos professores em formação, e continuou-se a utilizar o módulo de matemática da Poronga, já que não havia tempo hábil para a produção concomitante de um novo material, e também para o aprofundamento necessário à sua produção (MAIA, 2019). "Quanto à matemática, por terem os índios optado pelo uso da Cartilha 'Poronga', a assessoria no setor limitou-se a uma revisão de todas as suas lições. Contudo, já se idealizava a feitura de um livro que se referenciasse na etno-matemática dos diferentes grupos" (CABRAL et al. 1987, p. 22). A primeira cartilha de matemática publicada pela CPI-AC, a Cartilha de Educação Matemática para Crianças da Floresta, seria lançada apenas em 1990.

As diversas publicações desenvolvidas pela CPI-AC estão sempre inseridas em processos de formação, num primeiro momento, de professores (até 2008), e de 1996 até os dias atuais, de agentes agroflorestais, os AAFIs. O movimento se dá a partir dos cursos, resultando das discussões realizadas pelos indígenas em formação. Referindo-se, especificamente, aos materiais derivados dos cursos de formação de professores, Gleyson Teixeira ${ }^{14}$ explica como se dava o planejamento dos materiais:

\footnotetext{
Você tinha, ali, nas aulas, sempre a proposição, digamos assim, da prática da escrita, do exercício de pensar a pesquisa, de pensar a documentação cultural ou de sua língua... Ou, claro, como se tratavam de professores, pensar também materiais, pensar a partir do "como vou dar essa aula?", "como vou trabalhar isso?". Primeiro definir, a partir das necessidades que eu observo e das características da comunidade, do meu povo, dos meus parentes, o que que é necessário trabalhar na escola. Então, isso exigia pensar como nós nos organizávamos, como não-indígenas formadores, pensando um currículo para atender a essas necessidades. E pensando, também, uma série de reflexões e atividades conjuntas que pudessem proporcionar uma meta-reflexão. $\mathrm{O}$ professor, ele está ali aprendendo e, ao mesmo tempo, pensando em quais estratégias utilizar para que esse aprendizado fosse também desenvolvido com seus alunos. (TEIXEIRA, 2018)
}

Os materiais didáticos eram constituídos a partir dos registros feitos, seja das discussões em sala de aula, dos planos de aula escritos, das atividades pensadas pelo conjunto de professores em formação (estes processos, via de regra, geravam as cartilhas para alfabetização em português ou outros materiais que poderiam ser aplicados em diversas etnias). Outra forma de concepção se dava a partir de pesquisas desenvolvidas pelos professores

14 Cientista social, faz parte da equipe da CPI-AC desde o final dos anos 1990 e atualmente é Coordenador Executivo e de Representação Institucional, além de dirigir o Programa de Educação e Pesquisa Indígena da entidade. Organizou e coordenou algumas das publicações da Coleção Autoria Indígena. 
Figura 10: Capas dos cadernos da Cartilha Poronga, desenvolvida em 1982 pelo Centro Ecumênico de Documentação e Informação (CEDI). Fonte: CEDI, 1984, p. 6.
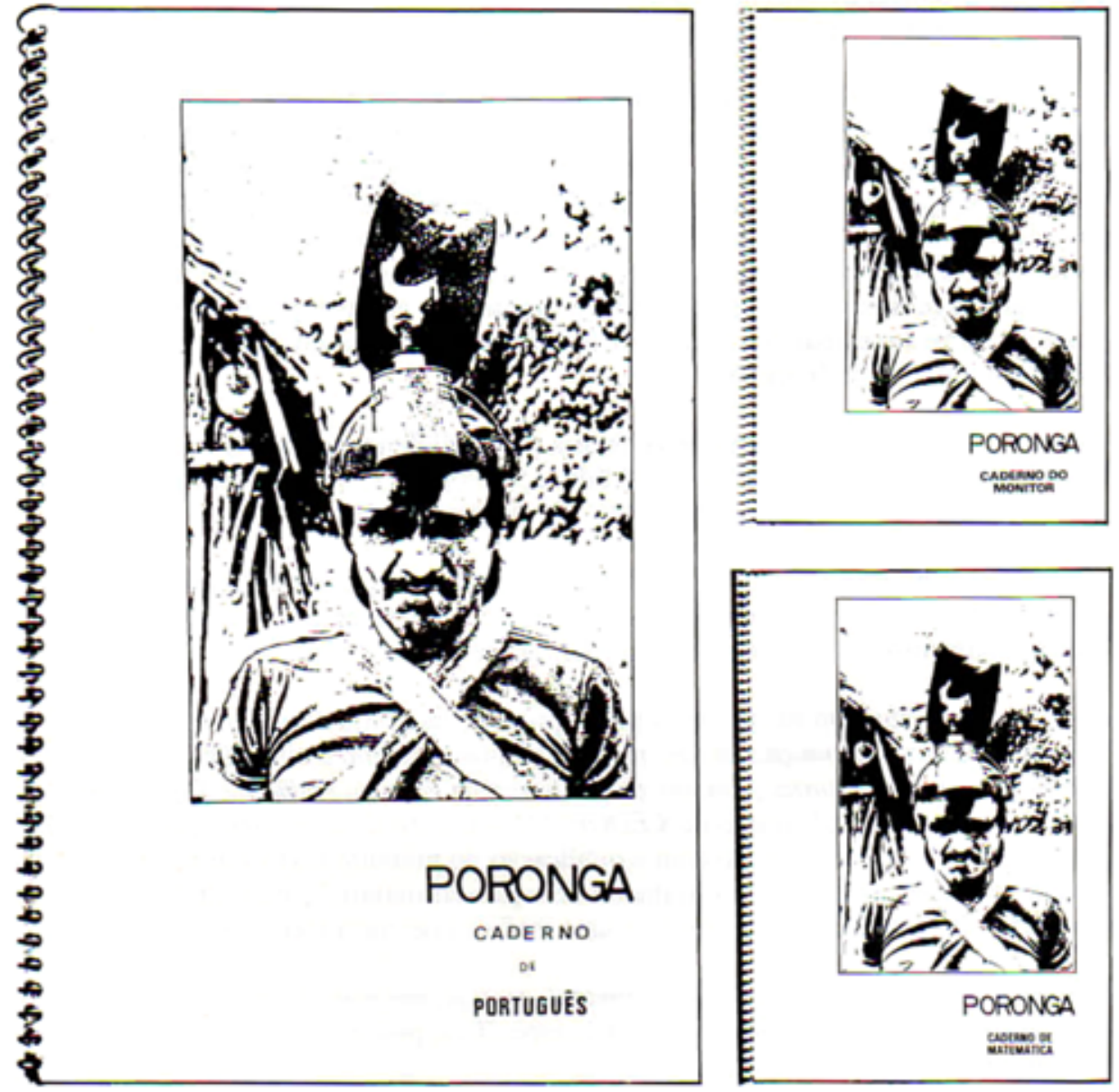

em suas respectivas escolas indígenas, através de relatos feitos em "diários de classe" (MONTE, 1996), registros orais coletados com gravadores e discussões com os "parentes" da comunidade - processo que resultava nas cartilhas de alfabetização ou outras disciplinas especificamente voltadas para uma respectiva etnia.

Outra coisa também: Nós recebemos gravador, máquina de bater, máquina para calcular, 2 gravadores, 2 máquinas para escrever, 5 para calcular para nós do Rio Jordão. Quando nós chegarmos na nossa aldeia, vamos gravar a nossa estória dos antigos que contam nossos parentes velhos sobre a nossa vivência. Sobre as estórias, depois de gravar, nós batemos com a máquina para tirar texto. A máquina e o gravador são para fazer isso. (depoimento de Joaquim Paulo Kaxinawá In CABRAL et al. 1987, p.32)

Há, também, os materiais que são frutos de discussões coletivas e acordos, dos quais Teixeira cita os planos de gestão territorial e ambiental. Estas publicações, apesar de não serem especificamente pensadas como parte de um currículo didático, podem ser empregadas na escola ao se pensar "estratégias e atividades para fortalecer a apropriação do conteúdo, dos acordos, das decisões, do planejamento de gestão da terra indígena, mas são publicações que nascem claramente como documentos políticos de decisões que eles tomaram, de registro" (TEIXEIRA, 2018).

São documentos políticos, e documentos não só para fora, mas, principalmente, para dentro, que reforçam os acordos que eles fizeram para a gestão dos recursos na- 
turais e para pensar as estratégias de proteção territorial. Então, esse tipo de publicação é muito comum, hoje, e o contexto de criação delas é esse. (TEIXEIRA, 2018)

Um outro caso seria a publicação de pesquisas desenvolvidas por professores e AAFis já formados, que decidem abordar elementos específicos de suas culturas.

São pesquisas individuais. Muitas vezes, acontece que, alguns professores não levaram a frente toda a pesquisa, então ela acabou, digamos assim, complementada por outros projetos de pesquisa, de outros professores do seu povo ou de sua comunidade. A gente entrava aí como editores disso, para reunir, com o apoio, muitas vezes, de um professor que se destacava como organizador ou co-organizador desse material, também.

Reunindo uma série de desenhos que foram feitos por alunos, ou pelos próprios professores, para ilustrar essa pesquisa, então, isso também era considerado. $\mathrm{E}$ a nossa entrada nisso era, justamente, no projeto gráfico era, digamos assim, tentar fazer, digamos, uma organização desses materiais, juntamente com algum professor que nos auxiliasse nisso, quando projetos coletivos. Agora, claro, toda a parte, por exemplo, de obter os recursos, obter o técnico, para a gente fazer o projeto gráfico, a diagramação, essas coisas, isso não era do professor, obviamente, a gente entrava com esse apoio. (TEIXEIRA, 2018)

O papel da CPI-AC em todos estes casos é o de auxiliar, posteriormente, na organização dos registros feitos pelos pesquisadores indígenas, e, conforme a necessidade, proporcionar que textos sejam traduzidos para o português por especialistas.

O material, uma vez reunido e organizado, "com o layout quase final", era então apresentado aos autores (no caso de publicações coletivas, ou ao autor no caso das pesquisas feitas por um pesquisador específico) para que se pudesse discutir e aprovar a configuração final do livro a ser publicado.

Já com o layout quase final. E aí ele olhava, fazia as correções necessárias, opinava, por exemplo, sobre... sobre... se a estrutura era aquilo, o que que poderia ou tinha a acrescentar e tal. Muitas das dúvidas existentes sobre... sobre... o conteúdo a gente fazia as perguntas, para deixar mais claro aquela exposição. Agora, os materiais em língua indígena, totalmente língua indígena, a gente já se apoiava em algum parente, da mesma etnia, do mesmo povo, algum outro professor, para também dar um feedback. (TEIXEIRA, 2018)

Pode-se afirmar que não existe um método único delimitado para a estruturação editorial dos materiais. De acordo com as entrevistas realizadas com os membros da instituição, cada publicação era desenvolvida com base nas especificidades do projeto em questão, seja este uma disciplina do curso de formação, uma pesquisa sobre a mitologia zde determinada etnia, uma oficina sobre a gestão territorial de certa terra indígena. Boa parte do desenvolvimento do processo de produção do impresso fica à cargo do coordenador definido para o projeto em questão, por exemplo, o monitor responsável pela disciplina no curso de formação. 
Não, era o coordenador, a pessoa que organizava o material. Porque o professor, era o seguinte: organizar o material didático também era um processo de aprendizagem dos professores, tanto é que depois eles tinham muita facilidade para organizarem os próprios materiais. Mas a gente fazia formação, discutia os conteúdos que estavam na proposta curricular e aquilo - dento de uma filosofia do conhecimento indígena - da voz, essa voz que geralmente sempre foi apagada. A voz indígena. Então, dando ênfase na pessoa, no aspecto político. E, no meu caso, era sempre discutindo os conhecimentos geográficos indígenas. Muitas vezes eles queriam conhecer a geografia não indígena, a geografia tradicional, e a gente sempre trabalhava para compreender como eram os meios de orientações indígenas, todo o conhecimento do meio ambiente, o conhecimento que eles tem da própria geografia da região que eles vivem. E aí se montava os materiais. Era o coordenador daquela disciplina, então, por exemplo, a Malu organizava materiais de história, ela trabalhava a história. E eu organizei muitos materiais na parte da geografia. Depois quando eu entrei e comecei a coordenar o programa de formação dos agroflorestais, os materiais já eram muito voltados a discussões de gestão do território, porque era muito sobre agricultura e a questão do meio ambiente, essa questão mais sócio-ambiental, manejo. Mas o mapa foi presente, a cartografia sempre esteve presente, então sempre teve essa coisa da cartografia. (GAVAZZI $\left.{ }^{15}, 2019\right)$

Contudo, algumas características comuns podem ser apontadas. A motivação para a seleção do tema a ser trabalhado sempre se origina das pautas colocadas pelos professores ou lideranças indígenas. Em seguida, o tema é discutido em conjunto entre assessores e autores, para que se possa delimitar temáticas básicas da produção dos textos. A edição dos textos, assim como a organização geral do material, geralmente fica a cargo do coordenador do projeto ou dos assessores da CPI-AC, mas sua atuação se dá de modo mais ou menos aprofundado de acordo com cada publicação.

É comum encontrar nos livros uma pequena apresentação que trata de sua produção e do contexto no qual o material foi desenvolvido - especialmente nas primeiras publicações. Constantemente imersos em complexos questionamentos conceituais no que diz respeito à formação e à autoria indígena, os processos editoriais da CPI-AC foram se desenvolvendo através da prática, ganhando mais força e forma de acordo com o passar dos anos e da quantidade de materiais publicados.

$\mathrm{Na}$ apresentação de O Jacaré Serviu de Ponte (1984), Monte (et al., 1984, s/ p.) escreve: "Aprendemos inventando um material de ajudar a ensinar nas suas comunidades". Pode-se compreender melhor o processo de "aprender inventando" a partir de alguns registros. No relatório apresentado à coordenação do Projeto Interação ${ }^{16}$, Monte explica que, durante os cursos,

15. Renato Antônio Gavazzi, geógrafo responsável pela coordenação da dsiciplina de geografia nos cursos de formação de professores promovidos pela CPI-AC, de cuja equipe começou a fazer parte em 1990. Foi responsável pela organização de uma série de livros da Coleção Autoria Indígena, voltados para Geografia Indígena, manejo da fauna e flora das TIs, atlas etc. Atualmente, continua atuando enquanto educador e consultor da CPI-AC.

16 Desenvolvido pelo Centro Nacional de Referência Cultural e um dos apoiadores técnicos e financeiros dos primeiros cursos de formação de professores da CPI-AC. 
versões preliminares das cartilhas em desenvolvimento eram reproduzidas em mimeógrafo para a sua utilização pelos monitores em sala de aula, para que pudessem ser trabalhados os exercícios. A compreensão dos mesmos era, então, examinada pelos assessores e monitores indígenas (MONTE In CABRAL et al. 1987, pgs. 36-37, 74). Mais adiante, ela descreve a elaboração de uma cartilha de pré-alfabetização, concebida a partir da experiência de professores kaxinawá.

Recentemente recebemos de um grupo de seis professores índios kaxinawá do Jordão uma nova cartilha de alfabetização feita por eles nas escolas. Nela, fica alterada a abordagem silábica proposta na cartilha do Índio Seringueiro: passam para um plano de destaque às letras do alfabeto, escritas logo nas primeiras páginas, em vários tipos - de forma, maiúscula, cursiva e script. As letras são retomadas em ordem alfabética, a partir de novas palavras geradoras selecionadas e desenhadas.

(...) Esta cartilha veio acompanhada da seguinte carta explicando o trabalho realizado: "Nós fizemos uns desenhos para publicar uma cartilha nova, para ensinar as criançadas que estão crescendo na comunidade. E quero que você ajeite para nós alguns erros que tiver. Porque nós achamos que esta cartilha é muito importante para nós começarmos a ensinar as crianças que nunca pegaram em ponta de lápis. Por isso é que nós queremos esta cartilha de treinamento para que eles comecem a treinar as letras. E depois começar a cartilha piaba ${ }^{17}$. Porque a cartilha piaba já é uma matéria de quase segundo grau... E assim, para criança de 5,8 ou de 10 anos é muito difícil pra eles..." (Joaquim Kaxinawá)

(...) Por isso mesmo, mais recentemente, para suprir as deficiências acima referidas da cartilha, preparamos um material considerado necessário pela prática dos monitores, destinado a uma fase anterior à etapa de leitura/palavras geradoras. (MONTE In CABRAL et al. 1987, p. 74-75)

Este material "de caligrafia" estava "em fase de teste nas escolas (com uma publicação provisória em mimeógrafo que pensamos em aperfeiçoar em processo)" (Ibid., p. 75). Especula-se que este processo originou a Cartilha de Pré-Alfabetização Escolas da Floresta, porém, como na publicação não consta o ano de sua publicação, não se pode afirmar com certeza - mas a configuração gráfica do material parece remeter à década de 1980. Em 1991 um novo material de pré-alfabetização é publicado, As Primeiras Letras, com a reconfiguração de conteúdos e exercícios. Este mesmo material foi reeditado em 1996, com novos exercícios e textos.

A produção de segundas edições de um mesmo material é uma prática comum, seja com o intuito de produzir mais exemplares de uma tiragem esgotada ou para realizar ajustes em exercícios ou na configuração gráfica

17 Cartilha Piaba era o apelido da Cartilha do Índio Seringueiro, o primeiro material didático produzido pela CPI-AC com a autoria dos professores indígenas, publicado em 1983 . O apelido se origina na primeira página da cartilha, que propõe "piaba" como palavra geradora. Especula-se que, no caso de danificação ou perda da capa, esta página era vista como capa do material. Outra possibilidade é que este nome derive do fato de não haver o título escrito na primeira capa, apenas na segunda capa. 

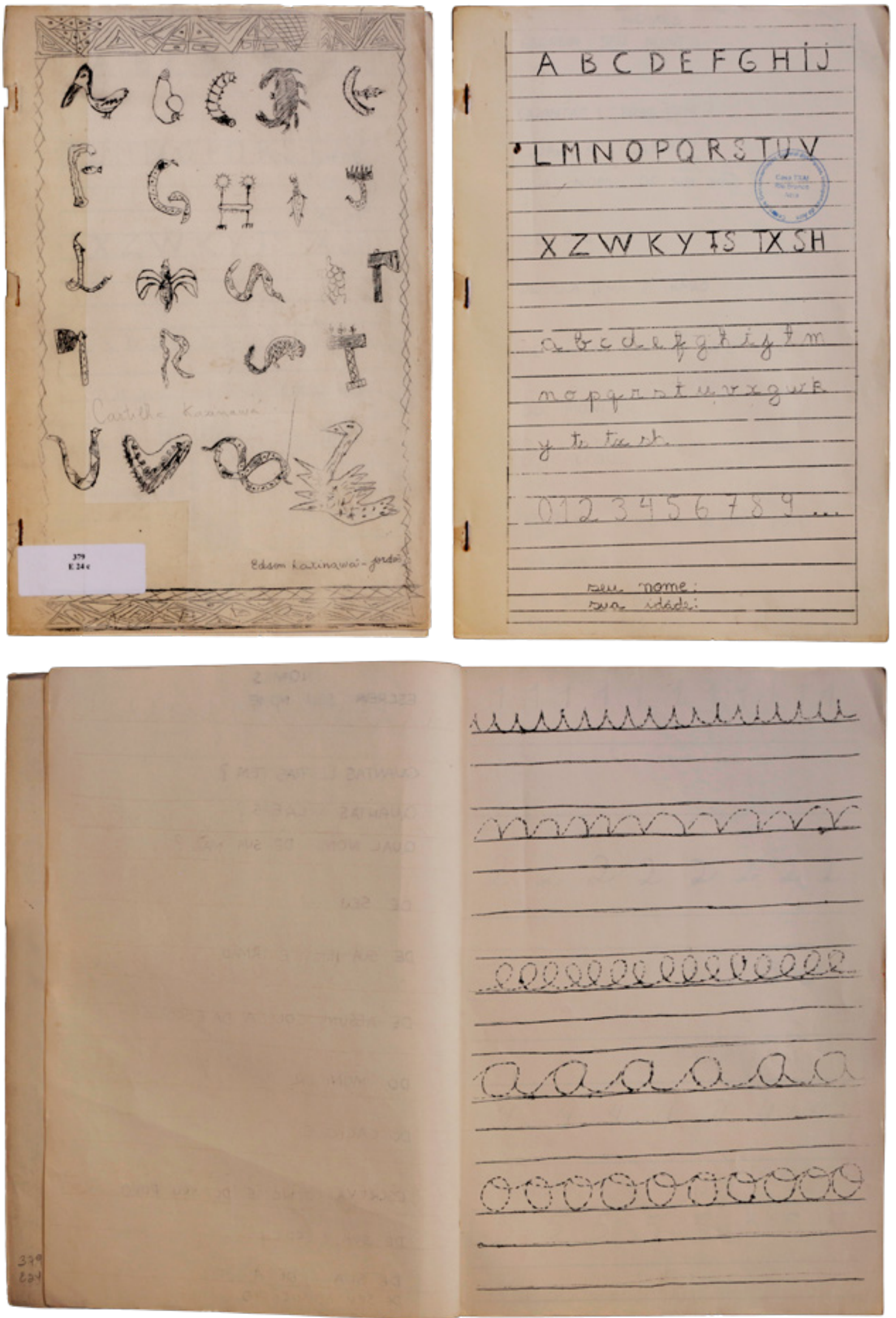

Figuras 11, 12 e 13: Primeira capa e páginas do miolo da Cartilha Kaxinawá (não há título na capa). Acredita-se que esta seja a cartilha feita por professores kaxinawá reproduzida em mimeógrafo a qual Monte (1987) se refere. Não há registro do ano na publicação, mas especula-se que a cartilha date da década de 1980. Fonte: Pesquisa de campo, Paiva (2019). 
/ visual dos mesmos. Um exemplo interessante é encontrado na Cartilha Katukina (para alfabetização em língua indígena). Sua primeira versão foi publicada em março de 1993, e uma segunda edição foi impressa em julho do mesmo ano com a seguinte apresentação, assinada pelo professor Benjamin André Katukina.

Cruzeiro do Sul, 02 de Julho de 1993.

Querida amiga professora,

Como te falei no telefone, a outra Cartilha Katukina, aquela que eu fiz no 12 Curso ficou muito difícil para os alunos, por isso eu fiz outra com meus alunos. Estou mandando para a CPI/AC e espero trabalhar com ela no mês de Agosto.

Com a Cartilha que fiz no Curso, estou trabalhando com os alunos adiantados. Um abraço para vocês da CPI. Façam com trabalho com minha Cartilha. (KATUKINA et al, 1993, s/ p.)

Os métodos didáticos aplicados no desenvolvimento dos cursos de formação e, posteriormente, pelos monitores indígenas em sala de aula, a adequação e eficácia dos materiais produzidos (SENA, 2019), e as demandas que surgiam nas comunidades indígenas eram avaliados, em conjunto, em três momentos principais: durante os cursos de formação, em momentos específicos de discussão conjunta entre monitores e assessores; nas viagens de assessoria, através dos relatos, da observação e da interação dos assessores nas terras indígenas; e com a leitura dos diários de classe produzidos pelos professores indígenas, onde os mesmos descrevem e ponderam sobre o cotidiano de suas salas de aula (MONTE In CABRAL et al. 1987, pgs. 17-49).

A assimilação da relação inerente entre esses quatro pilares do projeto de educação - a proposta pedagógica dos cursos de formação, o funcionamento das escolas indígenas, a produção e uso dos materiais didáticos, as demandas culturais, políticas, econômicas e sociais dos territórios - é algo que permeia todos as análises (posteriores ou não à execução do projeto) desenvolvidas pela CPI-AC e uma das características mais marcantes do programa de educação diferenciada concebido pela entidade.

A distribuição dos livros se dá, primordialmente, nas viagens realizadas às TIs, quando os títulos são levados pela equipe da CPI-AC, sejam estes relativos àquela etnia específica, ou de outras, propiciando uma troca de conhecimentos e pesquisas. Por outro lado, o movimento contrário também ocorre, quando professores, pesquisadores ou lideranças indígenas, em passagem pela capital do estado, solicitam publicações e as retiram diretamente na sede da instituição.

Os livros chegam da gráfica, depois que eles são impressos, e daí a gente manda pras terras indígenas. Eles dizem quantos eles querem. Ah eu quero 50 pra escola e 20 pra família. Eles que dizem. Aí eles levam, porque eles vem todo ano aqui, ou as equipes levam. É sempre assim. Agora se tem uma coisa que a gente precisa atualizar, porque ai também o que acontece, a distribuição, que é uma etapa muito importante, também, do material, ela ficou muito dependendo de oportunidades de viagens para as terras indígenas porque é caro você mandar uma caixa de livros pra uma aldeia. É muito caro, e nunca tem dinheiro. Principalmente caro, e nunca tem dinheiro. Então a distribuição precisa ser retomada com força agora. (SENA, 2019) 

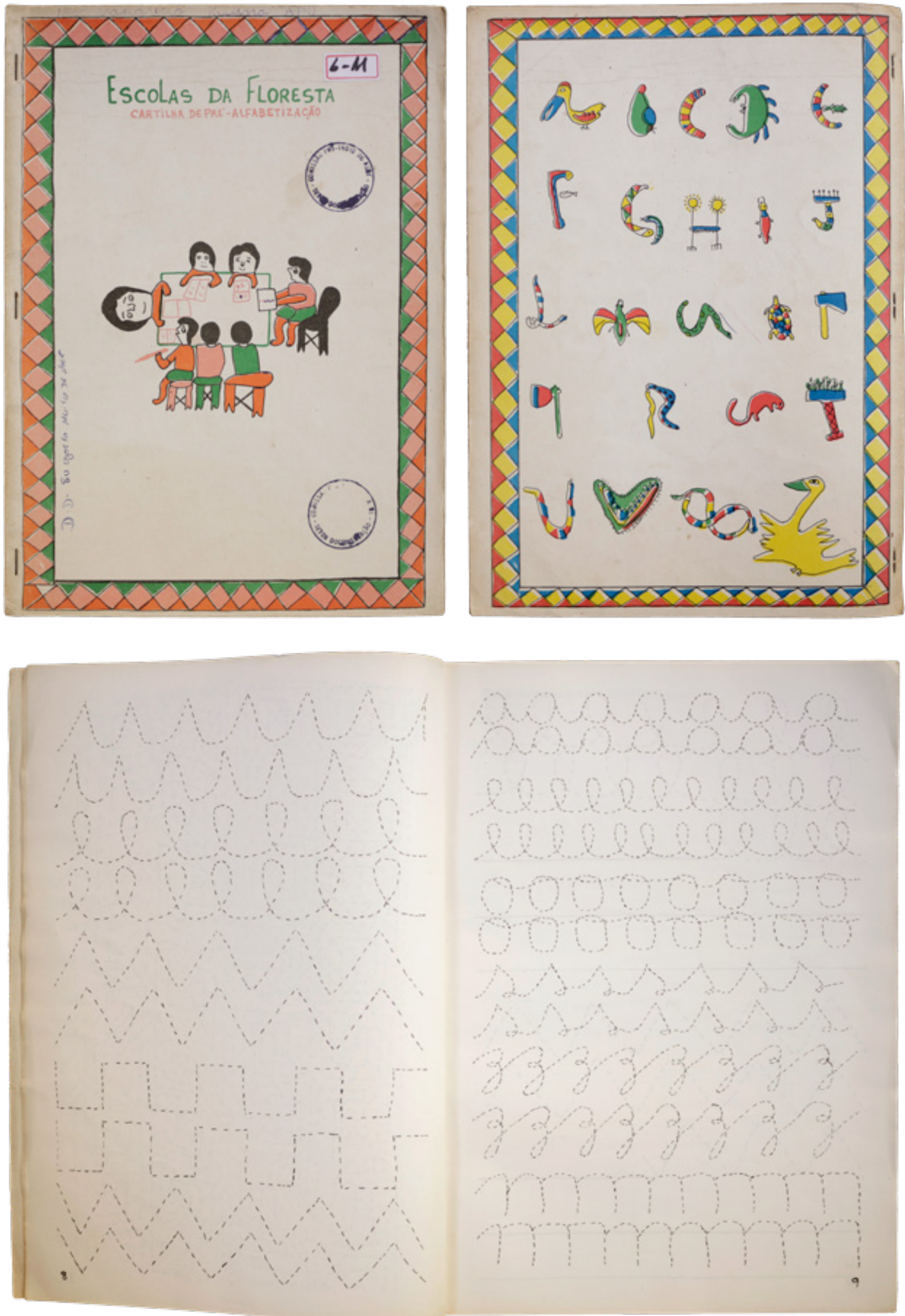

Figuras 14, 15 e 16: Primeira capa, quarta capa e páginas do miolo (respectivamente) do livro Escolas da Floresta - Cartilha de Pré-Alfabetização. Não há registro do ano na publicação, mas especula-se que a cartilha date da década de 1980. Fonte: Pesquisa de campo, Paiva (2019). 

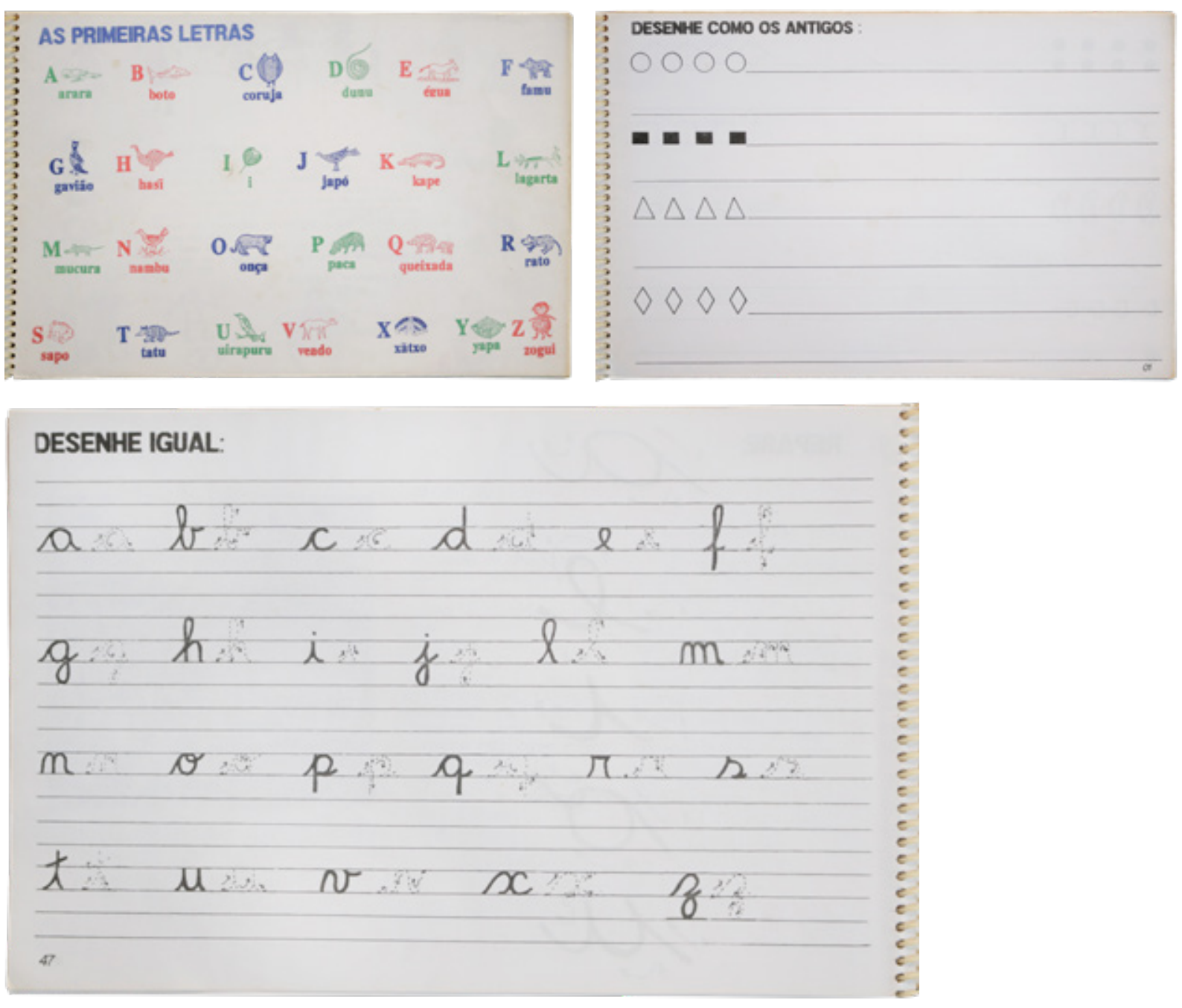

Há um interesse em acompanhar o uso dos materiais, mas, infelizmente, isso ainda não é feito de maneira sistemática. Apesar de retornos sobre a aceitação e utilização do material serem comuns nos contatos com professores, alunos e pesquisadores indígenas, "falta um feedback contínuo" (TEIXEIRA, 2018). Este era mais um papel significativo dos cursos de formação de professores realizados, onde haviam momentos e espaços especificamente dedicados à discussão e análise do uso dos materiais didáticos nas escolas.

Acontece que, sempre que a gente viaja para as terras indígenas, a gente leva materiais. Seja daquele povo, ou de outros, que seriam interessantes. E tudo dentro das publicações que nós estivemos envolvidos, né. Então, a gente faz essa distribuição, os professores, ou lideranças, ou membros, em passagem por aqui, que solicitam, também, essas publicações, nós entregamos, e uma das coisas que a gente acha que é super importante, que deveria ser feita é o acompanhamento do uso desses materiais. $\mathrm{O}$ acompanhamento, a gente não tem feito isso de maneira sistemática, o que seria muito interessante. Porque a distribuição ocorre, mas é super importante que, junto com essa distribuição - e isso que, em alguma medida, ocorre também - mas que assim, não há um tempo dedicado a perceber quais foram os usos realizados daquele material, ao incentivo de como ele pode ser

Figuras 17, 18 e 19: Primeira capa e páginas do miolo de As Primeiras Letras (1 ed., 1991). Uma segunda edição do livro foi publicada em 1996, com uma capa diferente. Fonte: Pesquisa de campo, Paiva (2019). 

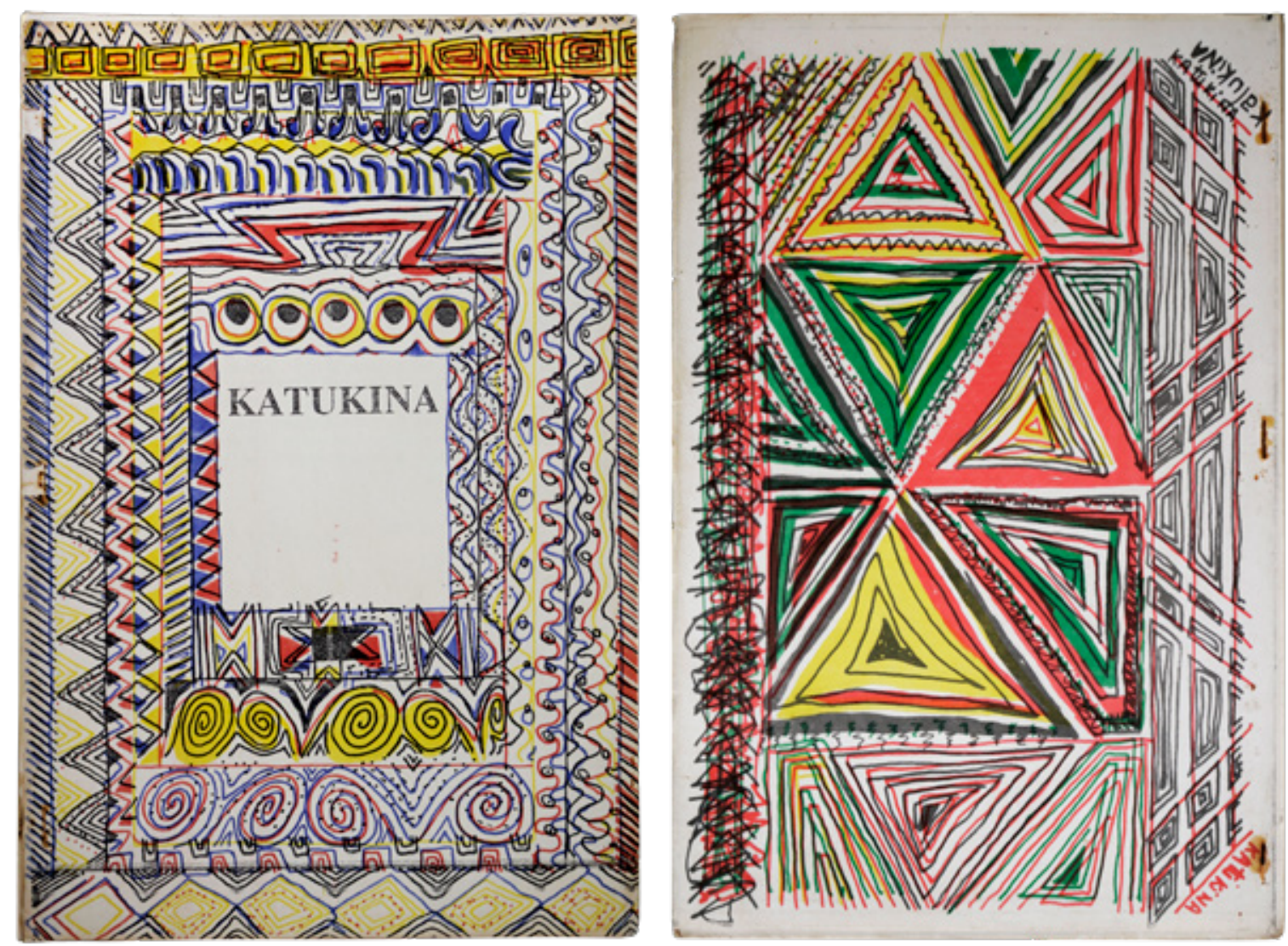

Figuras 20 e 21:

Primeiras capas da

Cartilha Katukina publicada em março de 1993 e da Cartilha Katukina publicada em julho do mesmo ano, respectivamente.

Fonte: Pesquisa de campo, Paiva (2019). usado. Mas esse feedback contínuo, ainda falta. A gente fez, em cursos de formação aqui, uma discussão com os professores, alguns anos atrás, enquanto tinham curso ainda, a gente tinha momentos do curso só pra discutir o uso dos materiais didáticos. Como eles estavam sendo empregados, como eles poderiam ser empregados, quais as dificuldades dos professores em utilizá-los, então... é isso. A distribuição aqui ela tem sido feita na medida em que nós vamos a terras indígenas ou quando nos encontramos e entregamos também para eles levarem. (TEIXEIRA, 2018)

Tinha [um mecanismo de avaliação e feedback dos livros]. Quando a gente fazia com regularidade, até 2008, as assessorias pedagógicas, um dos campos do roteiro de assessoria, das orientações de assessoria, era avaliar o uso, a aceitação e a função dos livros pelos professores indígenas. (SENA, 2019)

Alguns livros são mais requisitados por pesquisadores indígenas e não indígenas, dos quais Teixeira ressalta os planos de gestão territorial, por seu caráter documental, político e antropológico. Já Vera Olinda Sena destaca alguns livros de temática histórica e didática.

Olha, um livro que teve uma aceitação muito boa foi o História Indígena ${ }^{18}$. Esse livro foi, inclusive, reconhecido na época, o Geraldo mesquita, o Geraldinho, era do senado, ele fez uma sessão solene pra apresentar o livro, fez uma nova tiragem pra distribuir pras escolas. Um outro livro

18 História Indígena, cartilha lançada em 1996 e reeditada em 2002 com o nome Índios do Acre: História e Organização. Organizado por Maria Luiza Ochoa e Gleyson Araújo Teixeira, com autoria coletiva de professores kaxinawá, shawãdawa, manchineri, katukina, yawanawa, apurinã, poyanawa e nukini. 
que fez muito sucesso com vários projetos de educação é o Caderno de Reflexão do Professor Indígena ${ }^{19}$. Também fez muito sucesso esse livro. Ele inspirou 4 cursos de formação e de magistério indígena. E um outro livro que fez muito sucesso, além desses dois, é o Aprendendo Português nas Escolas da Floresta ${ }^{20}$. A gente tem aqui na CPI o um e o dois, e eles foram referência e modelo para vários "aprendendo português" em escolas de outras regiões. Por exemplo, tem o "aprendendo português nas escolas do Xingu", "aprendendo português nas escolas anhembi", "aprendendo português nas escolas xerente", eu acho... mas ele nasceu aqui. (SENA, 2019)

Outros materiais de demanda significativa, especificamente dentro das comunidades indígenas, são aqueles que abordam elementos culturais específicos de determinada cultura que geram um interesse e curiosidade para além do ambiente escolar (TEIXEIRA, 2018; SENA, 2019). Tais materiais passam a cumprir um importante papel de socialização e disseminação de conhecimentos em outros locais, como nos rituais religiosos (cantos do cipó), ou mesmo na aquisição de conhecimentos relacionados a práticas medicinais, culturais etc.

Ao ser questionado sobre a existência de algum interesse proveniente de editoras privadas em publicar os livros produzidos, Teixeira diz que não, e cita uma experiência com o livro Shenipabu Miyui - História dos Antigos (de 1996) que foi reeditado pela Universidade Federal de Minas Gerais em 2000, e figurou como leitura recomendada para o processo seletivo de ingresso na universidade em 2001. O maior acesso ao livro promovido pela iniciativa foi muito significante para a CPI-AC, assim como para o professor que organizou o material (Joaquim Maná, pesquisador kaxinawá de grande relevância ${ }^{21}$ ). Segundo Teixeira, foi um grande reconhecimento ver este livro ao lado de grandes obras consideradas como clássicos literários nacionais.

\subsection{0 letramento e a autoria indígena}

As sociedades indígenas do Brasil são consideradas ágrafas, ou seja, não fazem, tradicionalmente, o uso da escrita alfabética (GRUPIONI, 2008; SOUZA, 2006), tendo a oralidade como base para a transmissão de conhecimentos e manutenção de sua cultura. A tradição oral não implica, contudo, que outras formas de comunicação não verbal não florescessem entre os povos autóctones brasileiros. No caso particular dos Kaxinawá, por exemplo, um rabo de tatu era utilizado como convite para o mariri ${ }^{22}$ e outros eventos sociais - casamentos, rituais, entre outros - e buzinas e assovios específicos eram empregados para comunicação entre caçadores na mata (KAXINAWÁ et al., 199-, p. 180).

19 Caderno de Reflexão do Professor Indígena, lançado em 2005, com autoria coletiva de professores arara, ashaninka, kaxinawá, shawãdawa, manchineri, katukina e yawanawa. Organização, levantameto e digitação do material: Vera Olinda Sena e Jairo Lima.

20 Aprendendo Português nas Escolas da Floresta, lançado em 1993 e reeditado em 1997 em parceria com o MEC. Levantamento e organização: Tereza M. Maher, Vera O. Sena e Nietta Monte. Autoria coletiva de professores kaxinawá, shawãdawa, manchineri, katukina, apurinã, ashaninka e jaminawa.

21 Mais informações sobre o dr. Joaquim são apresentadas no capítulo 4.

22 Termo utilizado por vários povos da família Pano para denominar uma festa ou ritual comunitário que envolve cantos e danças (especificidades variam de acordo com cada etnia). 
Além disso, como coloca Souza (2006, s/ p.), ao se assumir a prática escritural enquanto o ato de realizar marcações manuais com instrumentos diversos, "a escrita sempre esteve presente nas culturas indígenas no Brasil na forma de grafismos feitos em cerâmica, tecidos, utensílios de madeira, cestaria e tatuagens".

Alguns povos indígenas possuem um contato já antigo com a escrita propriamente alfabética, decorrente, em um primeiro momento, do contato com os povos europeus e as iniciativas de catequização ofertadas pelos representantes da igreja católica ainda no período colonial (desde o século XVI), e que perseverou até o início do século XX. Voltado particularmente às crianças indígenas, o modelo escolar desenvolvido pelas ordens religiosas - das quais destaca-se a Companhia de Jesus - tinha como objetivo maior instruir práticas "civilizadas", tais como vestir-se, abandonar rituais de "feitiçaria" e adotar ao cristianismo, e assumir a língua portuguesa, em substituição às línguas autóctones (BERGAMASCHI, MEDEIROS, 2010; GRUPIONI, 2008).

Especialmente após a proclamação da República o Estado Nacional passa a investir mais esforços na territorialização e integração dos povos indígenas nos "demais segmentos da sociedade brasileira" (GRUPIONI, 2008, p. 12). O segundo momento do letramento indígena nacional se dá a partir da criação do Serviço de Proteção ao Índio e Localização dos Trabalhadores Nacionais (SPILTN), em 1910 (BERGAMASCHI, MEDEIROS, 2010). Escolas localizadas nas "reservas" indígenas passaram a oferecer fundamentos básicos para a escrita e leitura da língua portuguesa (ainda no sentido de estimular o abandono às línguas indígenas) e a inserir práticas sócio-culturais advindas do cotidiano das cidades - práticas civilizatórias, por assim dizer. Ademais, as iniciativas religiosas continuavam a atuar, inclusive, em parcerias com o Estado, compondo o sistema integrador de educação indígena que se seguiria como norma nas décadas seguintes (Ibid.).

Em 1967 o Serviço de Proteção ao Índio é substituído pela Fundação Nacional do Índio e o governo brasileiro firma um convênio com o Summer Institute of Linguistics (SIL), instituto que "levou para áreas indígenas linguistas de outras nacionalidades, muitos deles ligados a missões religiosas, os quais passaram a atuar no sentido de criar a escrita da língua de diversos povos" (Ibid., p. 58). Segundo Graúna (2013), a década de 1970 foi o período de "gestação" do que viria a ser o "fenômeno literário" indígena (SOUZA, $2006, \mathrm{~s} / \mathrm{p}$.) dos anos posteriores.

No estado do Acre, Monte ressalta três experiências de contato indígena com a escola formal "principalmente através das agências tradicionalmente responsáveis pelo contato nestas regiões: a empresa seringalista desde o início do século [XX], as 'Missões de Fé' (Missões Novas Tribos do Brasil, principalmente) a partir da década de 60 e a FUNAI, a partir de 1976" (MONTE In CABRAL et al., 1987, p. 11).

As iniciativas escolares seringalistas fazem parte da incorporação indígena à economia da borracha, e dizem respeito ao "amansamento" desses povos, um conjunto de práticas experienciadas de forma variada pelas etnias habitantes do território acreano, com o objetivo de subjulgar suas culturas e propiciar a exploração indiscriminada de sua mão de obra na exploração da seringa.

Os Poyanawa, por exemplo, durante o "tempo do cativeiro", trabalhavam e habitavam o seringal da Fazenda Barão e frequentavam a escola Cândido Rondon, criada em 1916 pelo patrão (dono do seringal) Coronel Mâncio Lima. Lá aprenderam noções básicas de matemática, português e a votar - Mâncio Lima foi duas vezes eleito prefeito do munícipio mais próximo, Cruzeiro do 
Sul. Numa situação totalmente danosa, os indígenas nem podiam de fato receber uma educação formal, já que os estudos eram menos importantes que o árduo trabalho na exploração de seringa, intercalando-se períodos curtos de frequência escolar e hiatos para dedicação exclusiva ao trabalho, nem conseguiam manter os conhecimentos tradicionais de sua etnia. Como consequência, no final da década de 1980, apenas os mais velhos conheciam a língua Poyanawa assim como a mitologia, conhecimentos científicos e técnicas tradicionais de artesanato (MONTE In CABRAL et al., 1987, p. 12).

"Escrita do contato" é como Monte (1996) denomina a relação dos Kaxinawá com a prática escritural, cujo primeiro contato também se dá no contexto dos seringais e das relações com os patrões. Antropólogos registraram sua fascinação pela habilidade de ler e escrever, vista como vantagem para a compreensão das contas e documentos mantidos pelos patrões e sobre os quais os indígenas não possuíam nenhum controle ou conhecimento - razão pela qual eram constantemente enganados (MONTE, 1996, p. 71-74).

As inciativas escolares das Missões Novas Tribos do Brasil se diferenciam pelo estudo das línguas indígenas, porém tais análises eram restritas aos pesquisadores das Missões, singularmente responsáveis por todos os processos de produção dos materiais escritos e da preparação pedagógica, desde a configuração dos exercícios, a tradução de "estórias estrangeiras", a produção de ilustrações, até a ortografia da língua indígena propriamente dita. Após a alfabetização em língua indígena, passava-se abruptamente à alfabetização em português e, daí, ao currículo oficial da Secretaria de Educação Municipal, sem nenhuma alteração ou ajuste às especificidades dos povos indígenas atendidos. Dessa forma, as escolas e materiais didáticos eram "simultaneamente externos e próprios aos índios" (MONTE In CABRAL et al., 1987, p. 13), o que causa uma série de conflitos, além do esvaziamento identitário e cultural da língua indígena, utilizada apenas como canal para uma aprendizagem que não se relaciona social, cultural ou historicamente com as etnias em questão.

Mesmo com os problemas relacionados às iniciativas missionárias, o saldo final das mesmas ainda era, de certa forma, mais proveitoso do que o proveniente das escolas dos seringais. No caso dos Yawanawa do Rio Gregório, por exemplo, Monte cita a construção de casas reformadas como escolas e enfermaria, uma pista de pouso e a escrita da língua indígena, posteriormente retrabalhada e redefinida pelos próprios Yawanawa (Ibid.).

Com a chegada da década de 1970 , a reestruturação política e econômica dos povos indígenas acreanos tem como importante desdobramento o surgimento das escolas indígenas bilíngues. Resultantes das articulações entre as lideranças e as novas entidades indigenistas, a ideia era que as escolas fossem administradas pelas comunidades, que selecionariam, também, aqueles que seriam os professores (MONTE, 1996).

A vontade de criação da escola indígena, realizada como parte de um projeto de libertação das relações sociais de "cativeiro", vividas desde há um século, correspondeu a uma extrema valorização da escrita alfabética como veículo e expressão da renovação da identidade social e da atenuação do sistema de exploração do capital regional sobre os grupos indígenas, enquanto classes trabalhadoras e do extrativismo. (MONTE, 1996, p. 75)

A noção de autoria, decorrente do letramento, surge fundamentalmente atrelada à busca dos povos indígenas pela emancipação política, advinda de um contexto de exploração socioeconômica e anulação cultural que se estendeu por séculos de contato e colonização. $O$ desenvolvimento da escola 
Figuras 22, 23, 24

e 25: Primeira capa, quarta capa, segunda capa, folha de rosto e páginas do miolo da Cartilha da Língua Kachinawa, publicada em 1978 pela Missão Novas Tribos do Brasil. Fonte: Pesquisa de campo, Paiva (2019).
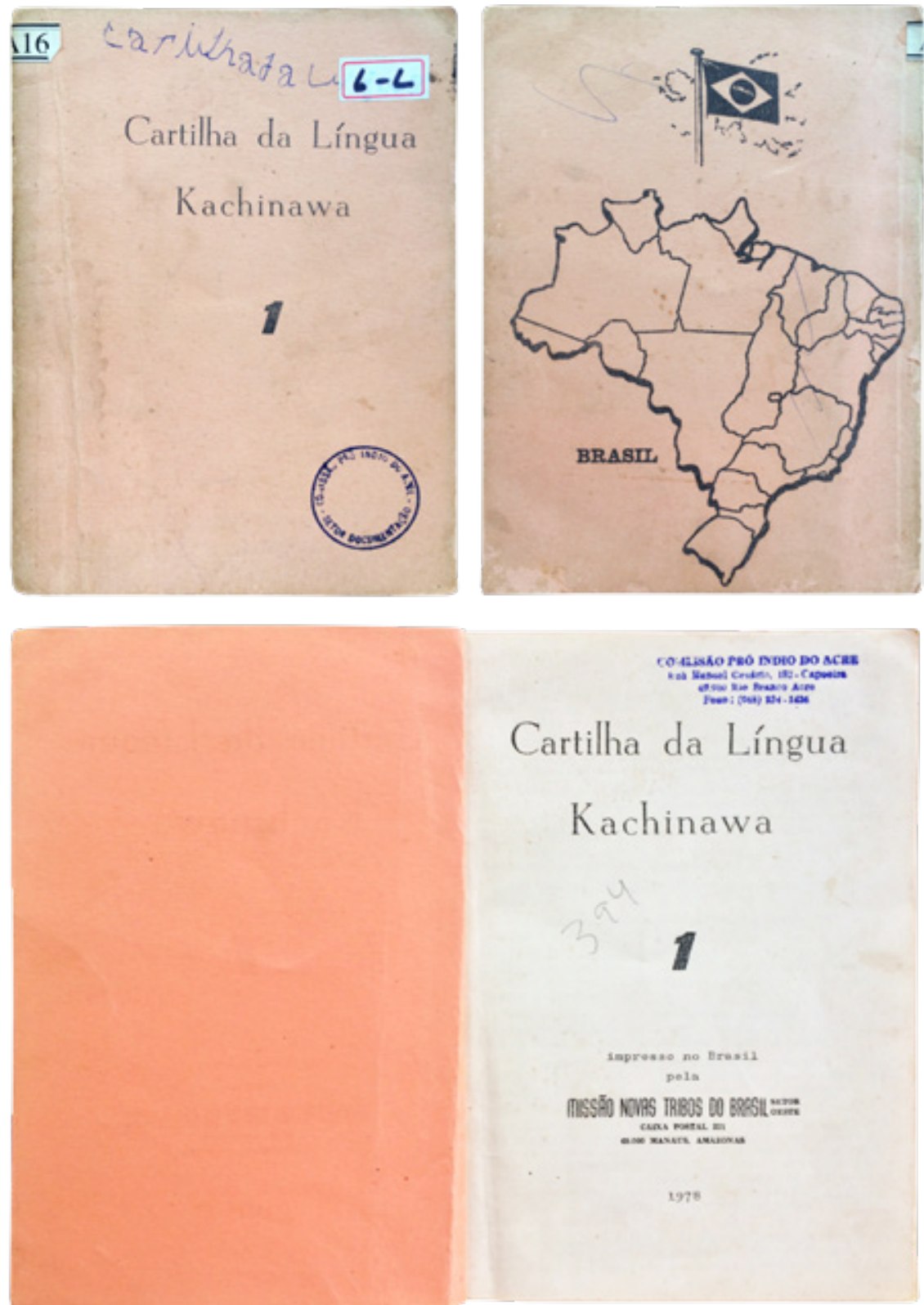
ton

$\begin{array}{llll}\text { b kp h s a e i u } & & \text { ā } & \text { i } \\ t w & & \text { bĩ } & \text { bu } \\ \text { a } & \text { e } & \text { ki } & \text { pu } \\ \text { ba pe } & \text { wi } & \\ \text { ka } & \text { we } & \text { pi } \\ \text { kä she } & \text { hi } \\ \text { ta che } & \\ \text { tsa } & & \\ \text { wa } & & \\ \text { ha } & & \end{array}$

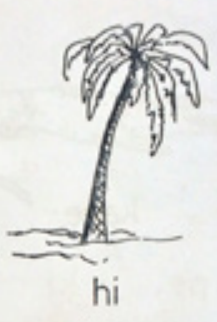

hi

kape

kape

hi

hi

kape

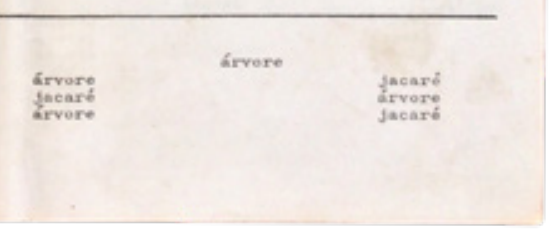


indígena é parte primordial dessa busca, assim como a produção de livros próprios é "um ato político e bem definido de um povo que busca sua afirmação" (LIMA, 2012, p. 13).

A escrita e a escola são, assim, concebidas como instrumento de controle social a ser progressivamente conquistado e internalizado, através das relações atuais dos índios com a sociedade nacional, sendo um dos bens de contato mais valorizados, com vistas possibilitar mudanças nas condições de vida destes grupos. (MONTE, 1996, p. 76)

E foi ainda na década de 1970 que, nas primeiras viagens de assessoria, antes mesmo do estabelecimento institucional da CPI-AC, já se delineava o conceito de autoria que posteriormente nortearia todas as ações da instituição através da coleta e registro de falas e depoimentos indígenas pelas assessoras. A compreensão da importância de dar ouvidos às narrativas e demandas apresentadas foi imediata e ficou cada vez mais óbvia com a elaboração do programa de educação que seria desenvolvido a partir dos anos 1980 (MONTE, 2008).

Durante o primeiro curso de formação de professores, em 1983, ao se produzir a primeira cartilha de alfabetização (publicada no final do mesmo ano), com os professores atuando como autores e proponentes das estratégias e exercícios educativos, percebeu-se a imensa importância da promoção de uma escrita autônoma, que pudesse expressar características inerentes das respectivas culturas indígenas. Além disso, o conceito da autoria se expandiu para além da composição dos textos publicados, ao envolver, também, as ilustrações produzidas pelos professores e alunos indígenas, assim como a própria concepção do modelo pedagógico utilizado em classe, que reverbera nos materiais didáticos desenvolvidos pelos professores (MONTE, 1996).

Esse novo discurso, construído com letras, palavras, imagens e papel, cumpre também uma função social: recém-saídos de uma situação social, política e economicamente caótica, os sujeitos indígenas podiam finalmente se reorganizar, reestabelecendo laços culturais e reafirmando sua própria identidade (KAXINAWÁ et al., 199-; MONTE, 1996). Como coloca Gomes, "formava-se uma educação de índio para índio, produzindo-se não livros sobre os índios, mas dos índios" (2014, p. 2).
A antropologia vem testemunhando o protagonismo indígena repercutido em ações culturais e comunicati- vas intrínsecas. Esse mesmo movimento, feito por esses povos até então sucumbidos aos termos cunhados para representá-los, nutre-se, por sua vez, de apropriações, hibridações e misturas, ultrajando o sentido tentador da autenticidade. (VIEIRA NETO, PEREIRA, 2007, p. 54)

Junto ao processo de aprendizagem, os professores eram incentivados a produzir "diários de classe", cadernos onde registravam o cotidiano das aulas. A prática foi tanto um método de acompanhamento e avaliação do processo educativo nas aldeias, ao estimular o registro, por parte dos professores, de sua rotina de aulas e da aprendizagem dos alunos; quanto uma ferramenta para construir o domínio e ampliar a assimilação da prática literária. Com a formulação dos materiais didáticos realizada pelos próprios professores indígenas, tais livros passaram a colecionar relatos, memórias, expressões gráficas e visuais, que vieram para consolidar a soma do conceito de autoria literária ao sujeito indígena (MONTE, 2003). 
CENÁRIO NACIONAL

\begin{tabular}{|c|c|c|c|}
\hline SÉC. XV & & Primeiros contatos com europeus & \multirow{4}{*}{$\begin{array}{l}\text { SIL } \\
\text { Escolas } \\
\text { seringalistas }\end{array}$} \\
\hline SÉC. XVI & & $\begin{array}{l}\text { Iniciativas catequizadoras da } \\
\text { igreja católica }\end{array}$ & \\
\hline \multirow[t]{4}{*}{ SÉC. XX } & 1920 & $\begin{array}{l}\text { SPILTR, escolas em áreas } \\
\text { indigenas: política integralista }\end{array}$ & \\
\hline & 1967 & $\begin{array}{l}\text { FUNAI, convênio com o SIL } \\
\text { (pesquisas para desenvolver a } \\
\text { grafia de línguas indígenas) }\end{array}$ & \\
\hline & 1970 & Pressão de lideranças indigenas & \multirow[b]{2}{*}{$\begin{array}{l}\text { Escolas } \\
\text { da floresta }\end{array}$} \\
\hline & 1988 & $\begin{array}{l}\text { O direito à educação diferenciada } \\
\text { é garantido pela Constituição }\end{array}$ & \\
\hline
\end{tabular}

ESCOLA COMO

INSTRUMENTO

DE DOMINAÇÃO,

REPRESSÃO

E "INTEGRAÇÃO"

ESCOLA COMO

INSTRUMENTO

DE AUTONOMIA

E LIBERTAÇÃO
Figura 26: Esquema com resumo dos estágios e iniciativas do letramento indígena no Brasil e no Acre com o passar do tempo. Fonte: Adaptação da autora a partir de Bergamachi \& Medeiros (2010); Monte (1996); Grupioni (2008); e Cabral (1987).
Embora interesse mais, para esta pesquisa, tratar das especificidades do Estado do Acre, é importante mencionar que, em todo o país, os anos 1970 foram um período de questionamentos e posicionamentos disruptivos no que diz respeito às políticas integralistas e ao tratamento, em geral, dado aos povos indígenas pelo Estado até então. Tais ensejos foram oficializados na Constituição de 1988, que, finalmente, assegurou às populações indígenas o direito à manutenção de suas línguas maternas, crenças, práticas socioculturais tradicionais, territórios e sistemas próprios de educação fundamental.

\begin{abstract}
A partir da atuação indígena no processo constituinte da década de 1980, a Constituição Federal em 1988 assegurou direitos importantes às suas sociedades, entre eles o direito à escola diferenciada. A Carta Magna reconheceu aos índios, no Artigo 231, "sua organização social, costumes, línguas, crenças e tradições", e no Artigo 210, § $2^{\circ}$, "a utilização de suas línguas maternas e processos próprios de aprendizagem". Ou seja, garantiu-lhes um ensino no idioma próprio, com processos pedagógicos que possibilitem aprender de acordo com sua cultura. (BERGAMASCHI; MEDEIROS, 2010, p. 59)
\end{abstract}

O direito constitucional à educação diferenciada, entretanto, não "se traduziu em políticas consistentes de apoio à manutenção e à valorização das muitas línguas indígenas faladas atualmente no Brasil, ainda que iniciativas importantes tenham sido experimentadas nos últimos anos" (GRUPIONI, 2008, p. 12). As populações indígenas encontram-se em variados estágios e momentos de acesso à escolaridade, e "co-existem pelo Brasil afora, nas escolas indígenas, práticas escolares ultrapassadas e experiências extremamente interessantes e criativas" (GRUPIONI, 2008, p. 14).

Todavia, a Constituição de 1988 e as guinadas políticas e econômicas do final do século XX propiciaram um significativo aumento da produção editorial de autoria indígena. Segundo Grupioni (2008), parte imprescindível dessa produção são os materiais didáticos produzidos por professores indígenas, potencializando o acesso à escrita nas escolas diferenciadas e multiplicando importantes reflexões a respeito das relações e articulações culturais dessas populações com os contextos nos quais estão inseridas.

Essa política nova de educação indígena no Brasil deu um impulso nunca antes visto para o surgimento de uma nova escrita indígena, seja através da necessidade 
de criar novos materiais didáticos com conteúdos indígenas para alimentar as escolas indígenas, seja através da formação de um novo público leitor formado pelo alunado dessas escolas pelo país afora, ou seja, ainda por causa dos vários programas de autoria indígena que surgiram em vários cursos de formação de professores indígenas para estimular a escrita e a produção de novos materiais didáticos para as escolas indígenas. (SOUZA, 2006, s/ p.)

A multiplicidade de processos e a complexidade dos contextos de produção e composição editorial dos livros de autoria indígena faz com que o próprio conceito da autoria indígena seja uma fonte abundante de análises. Destas, Souza (2006) aponta como pontos focais os contrastes entre a oralidade e a escrita - incluindo-se, aqui, discussões sobre gênero e sujeito literário; as especificidades culturais indígenas relativas ao conceito de "tempo" - "tempo mítico e tempo histórico"; e a visualidade dos livros produzidos.

A seguir, tais questões são pinceladas tomando como base o cotejamento entre considerações de Souza (2006) e os dados específicos da atuação da CPI-AC, levantados pela pesquisa. O intuito é buscar compreender, de modo geral, algumas das particularidades da prática autoral indígena, mais do que aprofundar-se nas complexas discussões teóricas necessárias para uma possível tentativa de definição intrínseca do conceito.

Segundo Monte, a autonomia foi a principal premissa do projeto pedagógico dos cursos de formação da CPI-AC, desde sua idealização: a equipe da entidade cumpriria um papel de assessoria, preocupando-se em não dirigir o trabalho a partir de fórmulas ou técnicas, mas sim de maneira a poder se adequar livremente às especificidades advindas dos professores indígenas. Com a editoração dos primeiros materiais durante o primeiro curso, "o fundamento na linguagem e a noção de autoria daí decorrente constituíam-se como pressupostos básicos do projeto em sua dimensão pedagógica bilíngue e intercultural" (MONTE, 1996, p. 17). Com o passar dos anos e o desenvolvimento de outras linhas de atuação, para além do projeto de educação e formação de professores, a autoria tornou-se o princípio norteador das ações da entidade, tanto no que diz respeito à produção de materiais diversos, quanto na própria concepção de novos projetos.

Então, o conceito de autoria é for te nos projetos da CPI-AC porque era tudo feito em diálogo com os índios, a CPI-AC nunca disse assim: "ah, agora a gente acha que uma oficina de artesanato é importante, então a gente vai lá e leva". Não, tudo é os índios que dizem: "olha, a gente acha, a gente pensa, a gente quer"... e ser autor é muito, também, investir pelo lado nosso aqui do indigenismo, da formação e de mediadores, né, os professores, formadores de indígenas. É muito baseada em investir em capacidades de produzir conhecimentos indígenas. Então, é mediar isso, mediar a produção desse conhecimento, a manutenção desses conhecimentos, a divulgação desses conhecimentos, mediar a sistematização desses conhecimentos, além de só participar de definições e decisões. Porque, eu quero determinado projeto, isso os índios falando: "eu quero determinado projeto, pra isso e dessa forma". Isso também é uma das maneiras que a autoria se materializa, é também todos os espaços de formação da CPI-AC, cursos, oficinas, intercâmbios reuniões, viagens pras terras indígenas. É uma equipe de higienistas, uma equipe técnica que sempre se com- 
porta como mediador desse diálogo de conhecimentos. Mas, assim, mediador também de colaborar com o crescimento na qualificação de competências que vão ajudar os índios a produzir conhecimentos, manter conhecimentos, sistematizar conhecimentos, divulgar conhecimentos... então, é essa a maneira como a autoria se aplica nos projetos da CPI-AC. (SENA, 2019)

Segundo Vera Olinda Sena, a compreensão da autoria e de seu papel na atuação da entidade não é estático, modificando-se juntamente com as transformações e a evolução nas relações entre as populações indígenas e a sociedade não-indígena, assim como entre as mesmas e a própria CPI-AC. A relação entre a autoria indígena e o papel exercido pela CPI-AC é complexa e fluida, ao que Sena refere-se como "co-autoria".

Vamos dizer que você tem uma terra indígena no Acre com 600 mil hectares, e com 1.200 pessoas lá dentro. Essa TI, esse espaço geográfico, com essa sociedade dentro desse espaço, sofre muita influencia e muita pressão da nossa sociedade não-indígena. É muito forte, é muito rápido, é avassalador. Então, cada vez mais, essas culturas estão se misturando, cada vez mais esses conhecimentos são híbridos, e cada vez mais isso vai modificando esse conceito de autoria.

Chegou um determinado momento do projeto, e isso vale até hoje, desses projetos da CPI em que a co-autoria é muito presente também, porque não tem essa coisa: "ah a gente só vai lá, a gente não leva nada. Nós, não-indígenas, nós somos indigenistas da CPI-AC e a gente vai lá, a gente não leva nada, e nós estamos lá só pra aprender". Não, também não é isso. Porque tem muita coisa do mundo não indígena que os indígenas querem e precisam dominar. E isso hoje em dia já é bombástico, eles estão com muito mais domínio, eles estão circulando muito melhor nesse mundo, e não era assim 25 anos atrás

(...) É, das formações, mas também das transformações. Um movimento natural. A relação com os municípios, a relação com os projetos, eu não estou dizendo que isso é uma coisa ruim, eu tô dizendo que é inevitável. Então assim veio a autoria, a co-autoria. A autoria é muito presente, e a co-autoria não deixa de ser um recorte da modificação da autoria indígena. (SENA, 2019)

No que tange aos procedimentos específicos de editoração do material escrito para a composição de livros, a "co-autoria", conforme colocado por Sena, diz respeito ao processo de edição e revisão dos textos. Mais uma vez, não é possível determinar um método único para definir os níveis de intervenção feitos no texto original, no sentido de "sistematizar" conhecimentos e a própria linguagem escrita.

Então é a autoria e co-autoria indígena, e tudo muito complexo, porque, por exemplo, se você vai organizar um texto em língua portuguesa com um povo indígena que tem a língua indígena como primeira língua, a língua portuguesa vai ser a segunda língua desse povo. Quando você vai editar um texto, por exemplo, quando você vai editar um texto em língua portuguesa de uma pessoa que não é falante de língua portuguesa, você tem que botar conhecimento de uma cultura de língua 
portuguesa dentro da produção daquele texto do autor indígena, entente? Então, assim, tá entendendo a complexidade da história? Então desde a estrutura do livro, quando a gente tá falando da língua portuguesa como segunda língua, até conhecimento, culturas de mundos, até domínio e compreensão da sociedade não indígena, né. então quando o cara vai produzir um texto em língua portuguesa, às vezes ele usa inadequadamente determinada expressão, determinado termo, porque ele tem pouca experiência sociocultural da língua que ele tá escrevendo. Então, a nossa edição tem que botar essa cultura no texto. E isso não deixa de ser uma co-autoria. Você mexe, você edita um texto, colocando esses elementos que te dão co-autoria no material, entende? Então muda muito agora, junto com toda essa autoria, desde o que eu te falei, dessa produção, porque escolher os projetos, quais projetos, porque, onde, como, e tudo, eles são também toda essa produção de sistematização de conhecimentos e tal. Mas junto com isso, também, ainda também os princípios do indigenismo no Brasil. O indigenismo no Brasil obrigatoriamente tem por princípio a autonomia, o protagonismo, o coletivo, a flexibilidade, então isso também influencia, porque tem que influenciar, os processos de autoria. (SENA, 2019)

Souza (2006) atenta para essas intricadas relações ao discutir "a complexidade da situação do surgimento dessas narrativas no espaço problemático entre a oralidade e a escrita" (SOUZA, 2006, s/ p.). Segundo o autor, geralmente os editores não-indígenas tentam sistematizar os textos de autoria indígena no intuito de torná-los mais adequados aos gêneros literários da cultura escrita (poesia, ensaio, crônica etc), gêneros, estes, que não fazem sentido na tradição oral. Isto envolve, também, os contrastes entre a oralidade e a escrita, entre o ato de transcrever e o de escrever. Até que ponto, ao recontar em linguagem verbal histórias que são tradicionalmente narradas por diversos oradores e que, portanto, envolvem características próprias de performatividade (tais como a repetição, ênfase, entonação, pausas), estas características devem ser preservadas?

Quando questionada sobre a transição do conhecimento tradicionalmente oral para a língua escrita, Sena utiliza o exemplo dos livros de autoria kaxinawá (huni kuĩ) para afirmar que há uma "preocupação de manter uma língua escrita correta, mas com marcas da oralidade" (SENA, 2019).

Sim, você não pode fazer nenhuma mutilação da língua escrita, você tá trabalhando com educação e escola, então você tem que respeitar as normas gramaticais. Você não vai inventar uma outra língua escrita, porque isso é loucura. Embora tenha toda uma discussão de gente assim, que acha que tem que escrever do jeito que fala, mesmo. Mas a gente tem o cuidado de manter, sim, de manter, na edição do texto, a gente tem o cuidado de manter essa fala, huni kuĩ mesmo, o português huni kuĩ escrito. Pausada, repetitiva, tem um jeito de falar assim que é muito dele. A gente tem a preocupação de manter uma língua escrita correta, mas com marcas da oralidade huni kuĩ. (SENA, 2019)

É importante lembrar que os conteúdos pulicados pela CPI-AC são, via de regra, já editorados em forma escrita e mesmo quando advindos de depoimentos gravados, são transcritos pelos próprios professores indígenas, então cabe aos mesmos definir que características da oralidade manter (GA- 
VAZZI, 2019). Também é deles a decisão sobre quais conteúdos devem ser registrados de forma escrita e quais conteúdos permanecem transmitidos oralmente (TEIXEIRA, 2018).

Bom, tem uma coisa que, logo quando eu comecei, me chamou bastante atenção, foi a fala de alguns professores indígenas, que eles ressaltavam o seguinte: quando a escrita e os materiais vinham em auxílio, e quando eles eram desnecessários. E eu vi muito afirmando que, naquilo que a oralidade dava conta, eles não viam tanta necessidade de registrar. Mas aquilo que eles começavam a perceber que seria muito interessante, ou porque... tava... muito restrito a algumas famílias, a alguns velhos, era algo que tinha alguma chance de perder, eles viam, assim, nesse momento é muito importante fazer o registro, a documentação, pra isso não ir embora com o velho. $E$ às vezes, também, questões de outra ordem: o quanto aquele conhecimento, em qual estado de aquisição e transmissão daquele conhecimento, daquelas práticas, na atualidade, entre aquela comunidade, será que os espaços estão sendo suficientes para isso? Claro que a escola não vai ser, não se pode, digamos assim, centralizar e criar expectativas de que a escola vai segurar essas coisas. Mas, assim, a preocupação de alguns professores em criar, tirando aqueles materiais que eram materiais destinados ao ensino, de você pensar a alfabetização em língua indígena, língua portuguesa, matemática e tal, mas outros. A necessidade, por exemplo, "nós vamos registrar isso aqui, pra isso não se perder", aí entrava, digamos assim, a importância da escrita, nesse sentido. (TEIXEIRA, 2018)

Tratando-se das narrativas tradicionais, a questão sobre a autoria coletiva desses conteúdos também é um ponto crucial das discussões sobre a autoria indígena (SOUZA, 2006). Tais narrativas, transmitidas oralmente por gerações e reproduzidas por diversos oradores dentro de uma mesma comunidade, assumem diferentes versões e confundem-se, muitas vezes, com posicionamentos e perspectivas subjetivas de quem conta aquela história.

Então, tem muitos desafios aí envolvidos, desafios enormes, para os próprios professores, ou pra quem assessora esses professores, ou agentes agroflorestais. Agora, o mais importante, assim, o mais importante que a gente tem feito é discutir, em alguma medida, isso, e deixar que eles tomem as decisões e que, nessas decisões tomadas, eles dialoguem, com seus parentes, naquilo que eles pensarem diferente do que foi feito. Do que era preciso registrar, ou se aquilo que foi registrado estava completo, ou não, as questões, mesmo, de definição, porque há, por exemplo, entre os povos, como os Kaxinawá que vivem no Jordão, ou os Kaxinawá que vivem no Purus, que receberam influências, por exemplo, um do espanhol e outro da língua portuguesa, que eles percebem diferenças, por exemplo, às vezes na própria grafia, coisas que eu acho que é preciso, primeiro, ter uma tradição escrita já ali, com elementos, com materiais e tal, pra se chegar a qualquer definição do que que seria... ou não chegar a definição nenhuma, também, eu acho que é importante ali, todas essas formas, essas variantes. (TEIXEIRA, 2018) 
Nesse caso, o registro escrito da narrativa pode ser uma fonte interessante para discussões sobre as versões da história, inclusive de acordo com os territórios habitados pela etnia (TEIXEIRA, 2018). De fato, durante a análise das publicações que compõem a Coleção Autoria Indígena, foram encontradas diferentes versões de várias histórias tradicionais, ou "mitos" de origem - seja a origem de determinada etnia, de práticas e rituais tradicionais, ou mesmo de substâncias e plantas (PAIVA, SOUSA, 2019).

\begin{abstract}
Muito comum, também, quando se tratava de narrativas, as impressões de diferentes velhos de versões daquilo, né. "Não, mas isso aí tá errado. Eu conheço a história de uma outra forma" e isso também era muito discutido, e é discutido, entre eles, eu acredito, como essas outras formas, podem, a partir do incentivo de uma, que já foi registrada, ter o seu momento de apresentação. (TEIXEIRA, 2018)
\end{abstract}

Souza (2006, s/ p.) também pontua que "o aspecto da autoria coletiva ou comunitária está ligado ao conceito de tempo mítico e tempo histórico nas culturas orais". Basicamente, o conceito de História tradicionalmente compreendido nas culturas não-indígenas ocidentais existe de modo distinto para as culturas indígenas brasileiras. Os "mitos" de criação do mundo, por exemplo, pertencem a um tempo anterior ao presente, mas que ainda mantém certa comunicação com a "atualidade" - em algumas culturas acredita-se que os xamãs possam movimentar-se entre esses dois tempos, servindo de acesso a essa ancestralidade (SOUZA, 2006).

A questão fundamental é: como distinguir as narrativas "míticas" e a História de determinada etnia? Qual seria o critério para estabelecer a diferença, ou mesmo a hierarquia, entre a cosmologia e os fatos? Essas questões são complexas e apresentam-se de diversas maneiras nos materiais da Coleção. Por exemplo, o segundo material produzido, O Jacaré Serviu de Ponte (1984), tem como subtítulo Estórias de Hoje e de Antigamente. Na apresentação do material, Monte (1984) explica que a primeira parte do livro é composta por relatos que narram o dia-a-dia nas aldeias, incluindo desde o trabalho com a seringa às práticas tradicionais como "a maneira de celebrar - suas danças, cantos e festas" e "as mudanças que vem sofrendo depois do contato com as cidades, o modo como vivem, sentem e pensam tudo isso" (MONTE et al., 1984, s/ p.). Já a segunda parte é descrita da seguinte forma:

\footnotetext{
Na segunda parte do livro estão as "estórias de antigamente". Nome que os monitores deram a este tipo de narração, onde seus antepassados são protagonistas de aventuras com quatipurus, cobras, sapos e aranhas encantados. Estórias que explicam, de um jeito muito próprio, a origem da lua, da noite, do tecido. Podem também ser compreendidas como "estórias de antigamente" por já estarem quase em desaparecimento entre os mais jovens, pertencendo hoje apenas à memória dos velhos, chefes $\mathrm{e}$ pajés das comunidades. (MONTE et al., 1984, s/ p.)
}

Ou seja, há uma distinção temporal que é nomeada pelos próprios professores (na época chamados de monitores) como "antigamente" e que remete ao tempo anterior ao "contato com as cidades", mas ao adotar a palavra "estória", uma distinção já é feita em oposição à História, por assim dizer, não-mítica (MONTE et al., 1984).

Em 1992, no livro Geografia Indígena, encontram-se combinadas as "estórias" e as informações "científicas", como, por exemplo, no momento em que se discute o fenômeno do eclipse, apresentado através de uma 
ilustração em conjunto com uma poesia, de autoria coletiva, que explica como "a lua vai esconder o sol", narrando o eclipse presenciado pelos monitores em formação, em contraponto às crenças de "muita gente que nunca viu uma eclipse, / e pensa que o mundo vai acabar" (RESENDE, GAVAZZI, 1992, p. 8). Em seguida, tem-se a "História da Escuridão", texto de Fernando Luis Katuyuve Yawanawá que narra o mito do primeiro eclipse presenciado pelo povo Yawanawá: "foi a primeira escuridão que meu povo Yawanawá conta, meu avô contava, meu pai sempre conta e eu conto hoje também" (Ibid., p. 9). Neste pequeno exemplo, que constitui uma amostra tão ínfima - algumas páginas de um livro, em comparação à miríade de páginas das dezenas de livros que compõem o total da Coleção - tem-se condensadas boa parte das questões discutidas por Souza (2006). Um bom vislumbre da complexidade envolvida na produção editorial desses conteúdos, e de como a equipe da CPI-AC buscava resolvê-las, dentro de cada contexto, através de soluções apresentadas pelos próprios professores. Entende-se que fica a cargo do professor, em sala de aula, explorar as diferenças semânticas, ou mesmo científicas, entre as duas narrativas e seu papel na construção daquele conhecimento.

Geralmente essas pesquisas têm início com mais velhos, que conhecem as histórias e que guardam a memória do povo. É a partir da fala deste narrador que se vai escrever a história, da forma mais fiel que se puder. E como se trata de uma literatura de cerne oral, ela é escrita a partir da voz, com o propósito de se retornar a ela, garantindo assim sua continuidade através do tempo. (LIMA, 2012, p.18)

Em 1996, com a publicação do primeiro material de história, História Indígena, a distinção temporal é melhor desenvolvida com a definição dos "tempos indígenas" (apresentados em detalhe na primeira seção desse capítulo). O material foi um grande sucesso, sendo reeditado com conteúdo expandido sob o título Índios no Acre - História e Organização (199-). No primeiro capítulo do livro, professores de diversas etnias dão sua perspectiva para a construção de um conceito indígena da História, alguns ressaltam a importância de não esquecer o passado, outros encaram a história também como o ato de imaginar o futuro, falam dos anciãos das comunidades e seu papel como guardiões das tradições, das diferenças e semelhanças entre as histórias de etnias distintas. Não há uma definição única, mas sim uma construção e reflexão sobre os pontos de vista daqueles que constroem o livro.

Tendo em vista que o objetivo principal do surgimento desses livros, dentro do contexto da nova escola indígena, é de resgatar as culturas indígenas, o que mais se vê nesse fenômeno da recente escrita indígena é o surgimento de uma nova cultura indígena atravessando e confundindo fronteiras tênues entre a cultura escrita e cultura oral. (SOUZA, 2006, s/ p.)

Outro ponto de suma importância na composição do conceito da autoria indígena é a manifestação gráfica e visual, ou, como coloca Souza (2006) a "visualidade" dos livros. Embora as nuances desse tema sejam analisadas em maiores detalhes nos capítulos 3 e 4 dessa dissertação, importa, neste momento, fazer algumas considerações iniciais. As manifestações visuais tradicionais das etnias indígenas é incontestavelmente parte fundamental de sua cultura. Ainda segundo o autor, a grande maioria dos livros de escrita indígena são, assim como aqueles produzidos pela CPI-AC, ilustrados pelos próprios autores, individual ou coletivamente, o que tem suscitado 
uma discussão sobre caso se trataria de um novo fenômeno da arte indígena. $\mathrm{O}$ autor atenta para o tratamento gráfico final dado às publicações, via de regra "tutelados por pessoas de fora das comunidades indígenas" que "acabam também vítimas inocentes das armadilhas que separam a cultura oral da escrita" (SOUZA, 2006, s/ p.).

Como no caso dos gêneros textuais, muitas vezes esses "editores" desconhecem o papel e o valor do texto ou elemento visual naquela cultura indígena e, partindo de uma cultura que dá primazia à palavra escrita, acabam confundindo-se e atribuem ao texto escrito (que para algumas comunidades indígenas apenas "ilustra" ou complementa o texto visual) maior importância do que ao texto visual. Aliás, o diálogo elaborado entre os textos visuais e escritos na nova escrita indígena ainda merece ser estudado como um fenômeno à parte. (SOUZA, 2006, s/ p.)

Como exemplo para este tipo de "confusão" o pesquisador cita a reedição de Shenipabu Myiui - História dos Antigos, feita pela editora da Universidade Federal de Minas Gerais em 2000 (conforme previamente mencionado). $\mathrm{O}$ texto original, escrito de forma multimodal ${ }^{23}$ pelos professores kaxinawás, é apresentado na edição da CPI-AC acompanhado de ilustrações que são interligadas ao texto escrito e possuem destaque no projeto gráfico da publicação, reproduzidas a cores e ocupando, por vezes, páginas inteiras. Segundo Souza, "na re-edição do livro essa interligação se perde por completo" (SOUZA, 2006, s/ p.).

Mais do que reescrever a sua estória/história, as comunidades indígenas parecem já estar escrevendo sua história. De forma diferente das literaturas pós-coloniais de língua inglesa e francesa, que antes de tudo buscaram "escrever de volta" aos antigos centros colonizadores metropolitanos, para serem ouvidos e lidos, as comunidades indígenas brasileiras parecem ter se contentado em reescrever a sua história escrevendo para eles mesmos, construindo assim uma nova identidade indígena, ambígua e híbrida, ao mesmo tempo local (como vimos acima, "Kaxinawá do Acre", por exemplo) e nacional ("índio brasileiro"). (SOUZA, 2006, s/ p.)

Apesar desta pesquisa focar-se na produção editorial, para além de livros e manifestações visuais, a autoria indígena possui muitas outras facetas midiáticas. Há uma rica produção em vídeo, cinema, música, enfim, uma infinidade de manifestações e possibilidades através das quais os povos indígenas tem ecoado sua voz e sua identidade.

Eu acho que cada vez mais nós estamos tendo a oportunidade, agora, através da câmera, através da fotografia, de mostrar o lado criativo e artístico dos povos indígenas. Nós temos bons cineastas aqui, temos o Iubã, temos o Amarelão, temos o Monte, e, agora, em vez da escrita, está sendo através da imagem. Hoje, nós temos

23 Segundo Thiago (2007, p. 8) "um texto multimodal pode ser descrito como um texto que incorpora mais de uma modalidade de linguagem ou como um texto que realiza comunicação por meio de mais de um código semiótico". Em sua tese de doutorado, a pesquisadora explora a construção do texto multimodal de autoria indígena, aprofundando-se na análise linguística e semiótica dos conceitos de tempo, lugar e narrativa destas narrativas. 

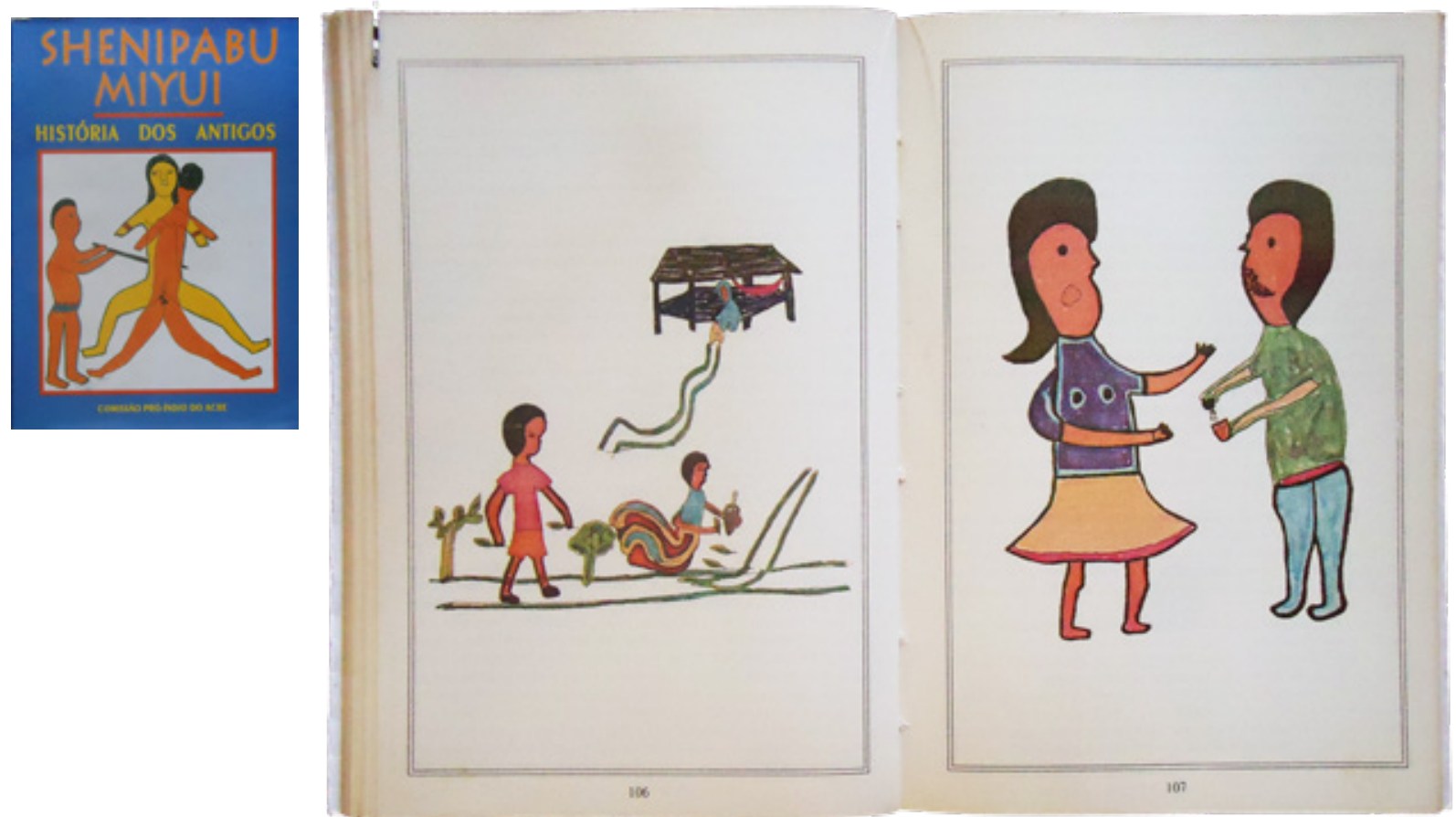

Figuras 27, 28 e 29: Primeira capa (reduzida) e páginas do miolo de Shenipabu

Miyui - História dos Antigos, publicado em 1996 pela CPIAC. As ilustrações são todas coloridas e temdestaque entre

o texto, ocupando intervalos bem definidos das histórias. Fonte: Pesquisa de campo, Paiva (2019).

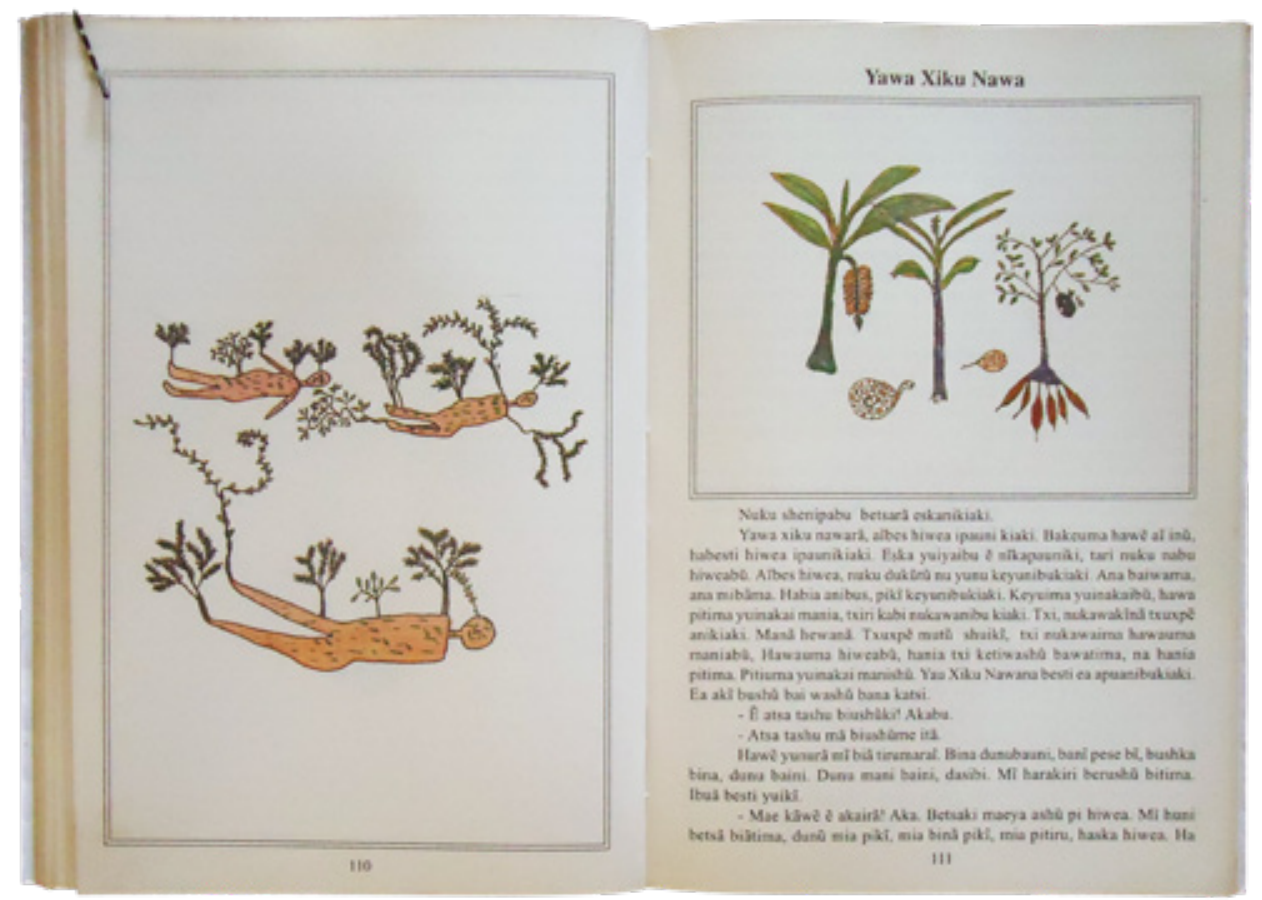

vários artistas indígenas hoje que tocam e cantam, estão fazendo vários cantos indígenas. A cultura, ela não é estática, ela está em pleno movimento. Eu acho que esses livros eles foram um bom start para despertar esse orgulho do ser indígena, do conhecimento indígena que antes era discriminado, tido como uma cultura baixa ou até dizer que a educação foi trazida pelos europeus. Ele quebra esse paradigma, ele mostra a criatividade e o bonito que tem dentro do mundo indígena. (TASHKÃ YAWANAWA $^{24}$, 2019)

24 O cineasta e pesquisador Joaquim Luiz Tashkã Yawanawa trabalhou como datilógrafo e digitador para a CPI-AC durante boa parte da década de 1990. Trata-se dele e de sua participação na Coleção Autoria Indígena em maiores detalhes no capítulo 3. 

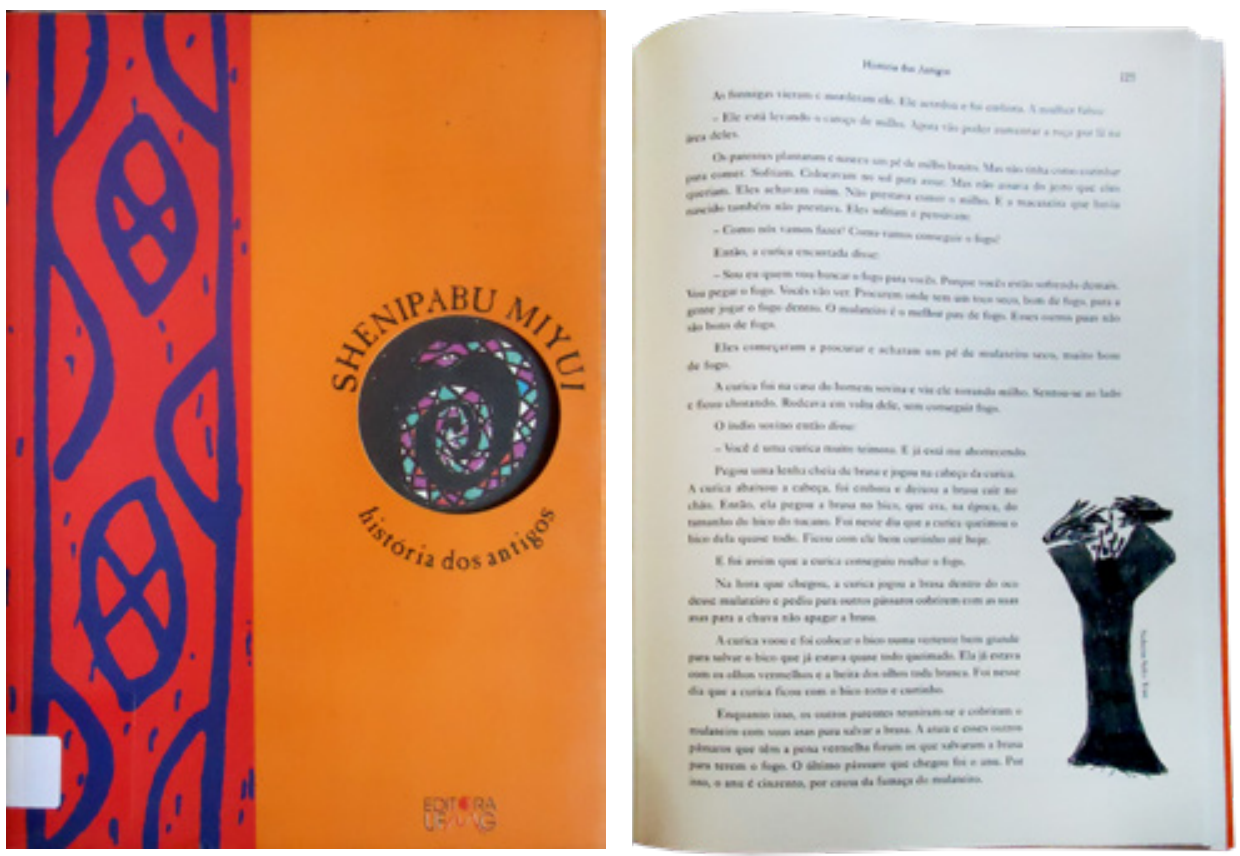

Figuras 30, 31, 32

e 33: Primeira capa e páginas do miolo de Shenipabu Miyui História dos Antigos, reeditado em 2001 pela UFMG. Apenas parte das ilustrações são coloridas, e as mesmas foram reposicionadas nas páginas do miolo, ocupando menos espaço e com menor destaque do que na edição original. Fonte: Pesquisa de campo, Paiva (2019).
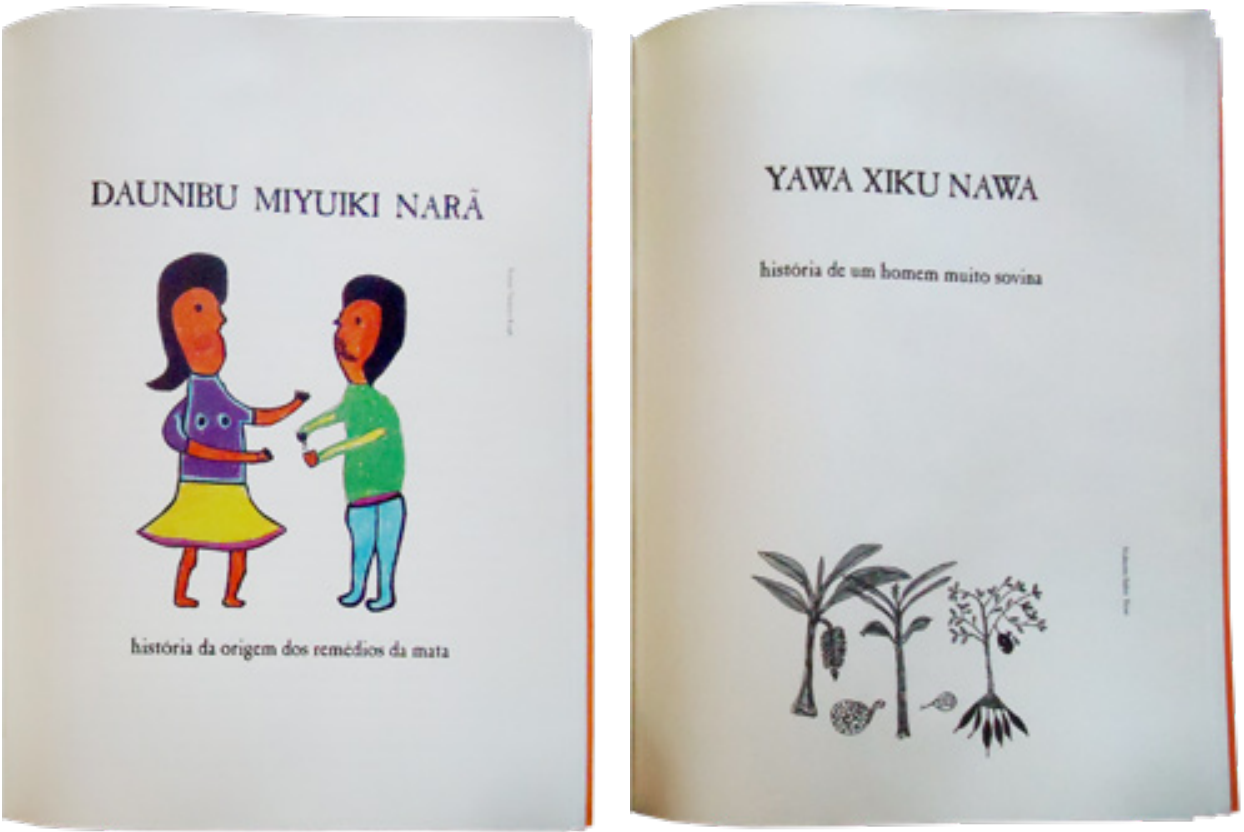

O impacto dos livros da Coleção Autoria Indígena (produto de 25 anos do início da prática da autoria, combinada aos processos didáticos) no movimento nacional de literatura indígena é atestado pela pesquisadora Maria Inês de Almeida ao posicionar o projeto "Uma experiência de autoria" e as escolas da floresta como a origem de um "movimento político literário indígena", influenciando e instigando uma série de produções literárias posteriores, produzidas pelo MEC - então Ministério da Educação (ALMEIDA, 1999 apud GRAÚNA, 2013, p. 86), em decorrência da entrada em vigor do Referencial Curricular Nacional para a Educação Indígena (elaborado em 1998) e. Além disso, Graça Graúna também afirma que "a prática da literatura entre os povos indígenas no Acre e em Minas Gerais propiciou o surgimento de uma geração de escritores e escritoras indígenas em outros estados brasileiros" (GRAÚNA, 2013, p. 86).

Olha, esse conceito [da autoria indígena] eu acho muito interessante, porque eu vou te dizer mais uma vez, hoje cada povo tem que fazer o seu, é um dever, tem que 
Figura 34: Professor Edgar Sereno com seus alunos, Aldeia Jacobina, TI Kaxinawá do Rio Breu. Foto de Cristiane Cotrim, 1997.

Fonte: Pesquisa de campo, Paiva (2019).

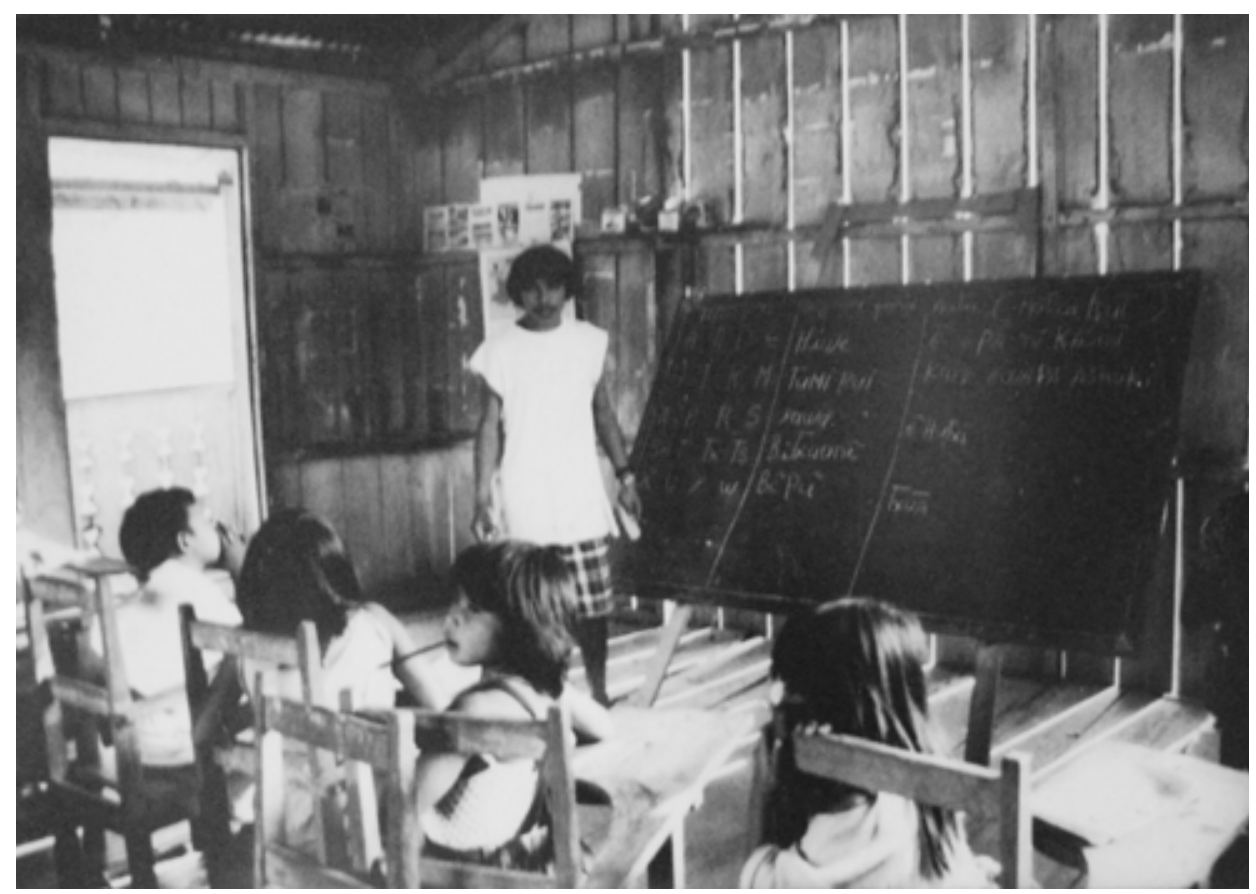

conceituar da forma que ele acha que deve ser, porque é muito bom você fazer. Fazer não é conhecer, conhecer não é mostrar, mostrar não é saber, então tem tudo uma conexão para se tornar um objeto de valor, importante, então quando você está fazendo isso você está dando importância, você está dando valor para aquilo que é seu, aquilo que você fez, aquilo que você quer que alguém chegue lá e vê que não fica só na ideia. Porque uma coisa é eu falar para você e outra coisa é eu chegar aqui e te mostrar, então é nesse sentido, é fazer e o mostrar o concreto, não o abstrato. Isso é muito interessante porque a CPI em si ela motiva muito o povo indígena tanto na publicação de material quanto na formação dos agentes agroflorestais. Já fez com professores como já fez com agentes de saúde, então isso demonstra que ela tem um compromisso muito forte, muito grande com essa infinidade de povos indígenas, em quarenta anos ela só desenvolve mais ainda e melhora mais a qualidade dos nossos trabalhos, de divulgar, produzir, publicar... (GOMES SHAMENAWA, 2019)

A autoria indígena é, intrinsicamente, um "um ato político e bem definido de um povo que busca sua afirmação" (LIMA, 2012, p. 13). Gallois (2007), ao analisar a materialização de saberes imateriais em "novos" produtos culturais (neste caso específico, os livros de autoria indígena, produto cultural e bem material que não faz parte da cultura indígena tradicional), afirma que, para além das dimensões mercadológica e econômica relacionadas à produção desses "bens culturais", importa mais a "produção dos produtores" desses "bens". "É no campo do reconhecimento político, da agregação de valores simbólicos, que eles contribuem para a construção da cidadania das populações indígenas" (GALLOIS, 2007, p. 98). A influência exercida pelo projeto "Uma Experiência de Autoria dos Índios do Acre" e, consequentemente, da Coleção Autoria Indígena, tanto política quanto socialmente, são exemplos desta construção.

Com isto em mente, no próximo capítulo a história e as características editoriais e gráficas dos volumes da Coleção Autoria Indígena são exploradas, a partir de dados quantitativos e qualitativos levantados pela pesquisa. 


\section{A Coleção Autoria Indígena}

Este capítulo trata diretamente do objeto desta pesquisa, a Coleção Autoria Indígena. No intuito de compreender, por um lado, o desenvolvimento e progresso dos métodos editoriais aplicados pela CPI-AC com o passar dos anos e, por outro, as principais características visuais e técnicas de composição e reprodução gráficas utilizadas, o conteúdo aqui apresentado foi elaborado a partir do levantamento e da tabulação de dados a respeito dos livros da Coleção (preservados em acervo no CDPI); da cuidadosa observação dos aspectos visuais das publicações; das informações derivadas das entrevistas realizadas (com membros atuais e antigos da equipe da CPI-AC e designers contratados pela entidade); dos relatos e registros produzidos pela equipe da CPI-AC; e pelos conteúdos publicados nos próprios livros da Coleção. A estrutura do capítulo acompanha as décadas de produção dos livros, que são seguidas por observações gerais sobre a Coleção.

A Coleção Autoria Indígena é um conjunto de 92 livros publicados pela CPI-AC entre 1983 e 2008. Ela abrange os livros produzidos durante o projeto "Uma experiência de autoria dos índios do Acre", assim como outros títulos produzidos pela instituição como parte de projetos semelhantes relacionados à autoria e à educação indígena. Mesmo nos primeiros contatos feitos com a equipe da CPI-AC para a realização dessa pesquisa, já ficava claro que os livros eram voltados especificamente para a distribuição nas terras indígenas do estado, ou seja, sua produção não pertence à lógica de mercado dentro da qual operam editoras particulares em geral. Dessa forma, os métodos de composição editorial e reprodução técnica dos livros da Coleção obedecem a uma lógica própria, intrinsicamente relacionada aos projetos de formação de professores e educação indígena, além de outros projetos da instituição, dos quais se destaca a formação de agentes agroflorestais indígenas. $\mathrm{O}$ conjunto de livros da Coleção possui caráter eminentemente didático, embora nem todos tratem de disciplinas das escolas tradicionais (não-indígenas).

Em sua dissertação de mestrado, Didier de Moraes (2010) explora a visualidade do livro didático brasileiro nas décadas de 1970 e 1980 . Logo no início do trabalho, o autor faz um apanhado de definições teóricas do conceito de "livro didático" que provou-se muito útil para esta pesquisa. Seguindo o mesmo raciocínio do pesquisador, compreende-se, aqui, o livro didático enquanto 'toda obra produzida com a intenção de ser material escolar, ou seja, a ser utilizado em sala de aula" (BITTENCOURT, 1997, apud MORAES, 2010 p. 20). Excluindo-se a característica mercadológica, já que os livros produzidos não eram feitos para o mercado, assume-se as outras definições propostas por Meneses com o auxílio de Bittencourt: livros didáticos são coletâneas de conteúdos escolares, que, de maneira complexa, transpõem o "saber acadêmico" para conteúdos curriculares utilizados na construção do "saber escolar", e, dessa forma, são "um importante veículo portador de um sistema de valores, de uma ideologia, de uma cultura" (Ibid.). Mesmo os chamados livros de literatura ou, no caso específico da Coleção, as coletâneas de poesias, prosa e narrativas tradicionais, por serem adaptados e apresentados enquanto "livros de leitura e interpretação de texto" (Monte, 1996), incluindo, muitas vezes, exercícios em conjunto ao texto literário, também configuram-se enquanto livros didáticos (MORAES, 2010, p. 20). 

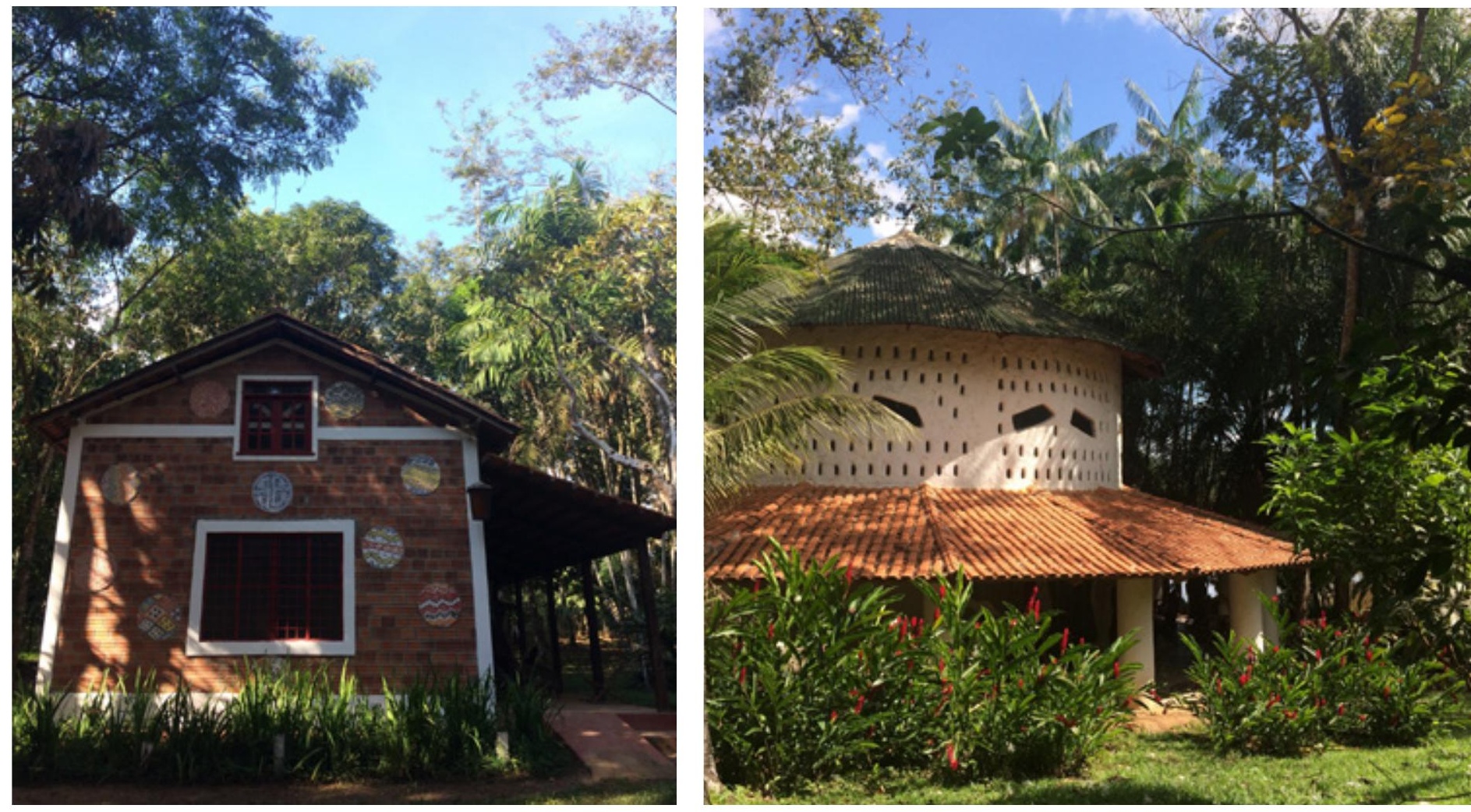

Figuras 35 e 36:

Prédios que compõem a sede da CPI-AC. Fonte: Pesquisa de campo, Paiva (2019).
Para a realização do levantamento aqui apresentado, foram realizadas duas viagens ao CDPI, localizado na sede da CPI-AC em Rio Branco. A primeira em julho de 2018, quando a pesquisadora passou cerca de um mês realizando o reconhecimento e o primeiro levantamento e registros dos livros $^{1}$ em acervo, em vias de desenvolver o recorte de análise para esta pesquisa. O segundo momento de imersão do acervo se deu durante os meses de maio, junho, e julho de 2019, e contou com registros fotográficos melhores dos livros, a computação de mais dados sobre sua produção e a realização de uma série de entrevistas com membros e colaboradores da CPI-AC.

Além do "Acervo Histórico" (de acordo com a nomenclatura utilizada em sua sinalização), que conta com os títulos da Coleção Autoria Indígena e todos os impressos (dentre livros de autoria indígena e não-indígena, panfletos, calendários, livretos etc) produzidos pela CPI-AC entre os anos de 1983 e 2008, no CDPI encontram-se também arquivados e disponíveis uma extensa coleção de livros de autoria indígena provenientes de outras instituições, assim como monografias escritas por professores e pesquisadores indígenas, materiais de registro dos cursos de formação (atas, trabalhos de classe, diários de professores e alunos, entre outros), o material original (manuscritos, ilustrações e até fotolitos) das publicações, uma coleção de arte indígena (cerâmicas, tecelagens, cestarias, esculturas), fotografias, CDs de música indígena, mapas das terras indígenas... e sem contar as publicações mais recentes (de 2012 a 2017) da instituição, que ainda são distribuídas para terras indígenas e utilizadas nos cursos de formação de agentes agroflorestais.

O acervo é organizado e os artefatos encontram-se categorizados em seções internas, dividindo-se em estantes, arquivos, prateleiras, gavetas e, inclusive, expostos em paredes e estantes especiais. A organização soma-se à beleza rústica do prédio resultando num ambiente extremamente agradá-

1 Excluem-se, por consequência, os folhetos, calendários, e outros produtos gráficos que não configuram-se enquanto livros. 

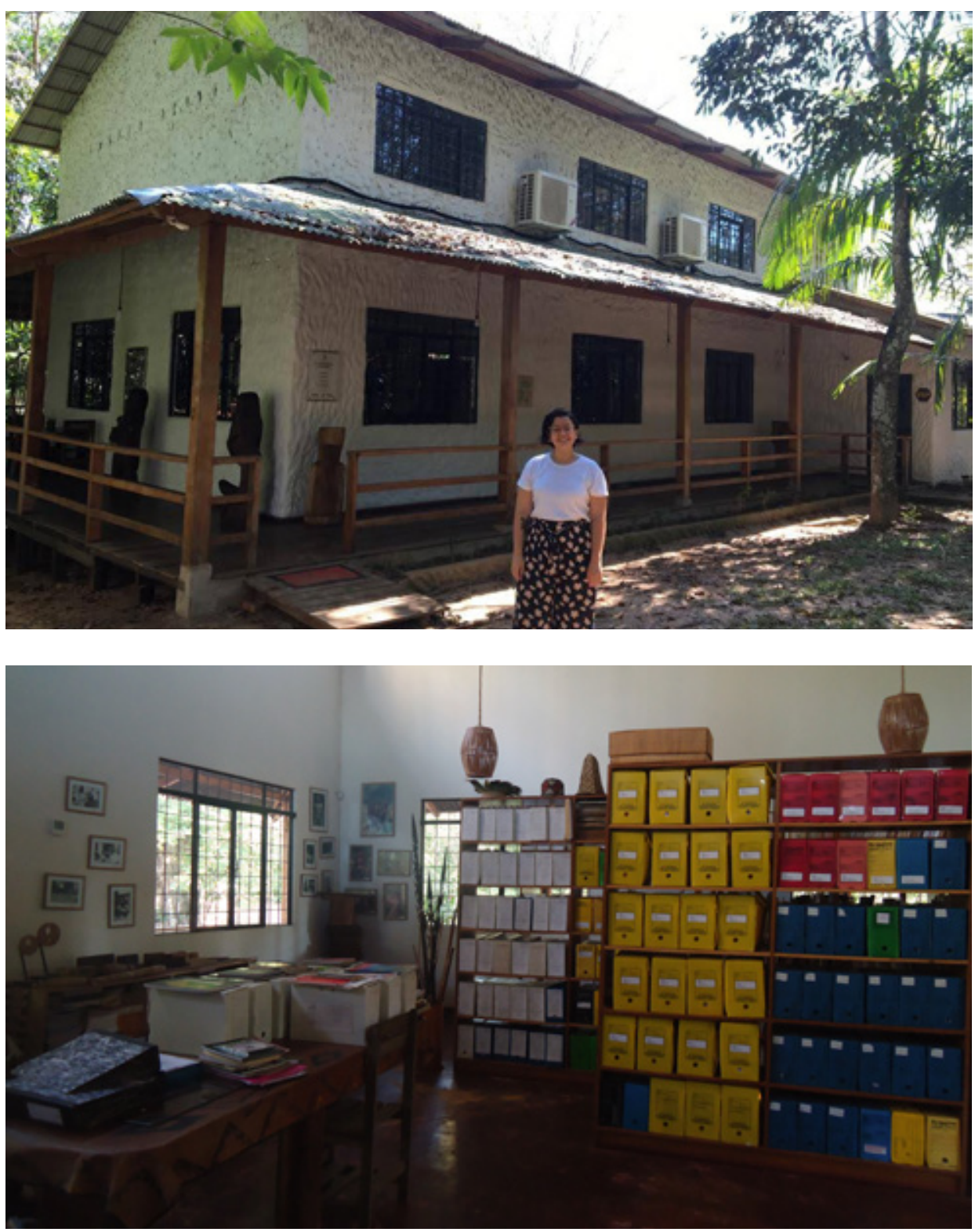

vel e convidativo, com mesas de estudos destinadas aos pesquisadores, ar-condicionado e internet sem fio. Durante as visitas ao acervo, percebeu-se a presença constante de pesquisadores visitantes ou funcionários da CPI-AC em busca de documentos ou livros.

A tabulação dos volumes que compõem a Coleção Autoria Indígena propiciou a compreensão de importantes características gerais do acervo. A começar pelo número total de volumes: a coleção é composta por 92 livros². Destes, 4 publicações foram realizadas por editoras externas, em parceria com a CPI-AC. Portanto, como não foram editorados diretamente pela entidade, optou-se por não incluí-los nos levantamentos. São estes: Antologia da Floresta (de 1997), uma coletânea de prosa e poesia de autores indígenas e não indígenas editado pela editora Multiletra; a segunda edição de Shenipabu Miyui - História dos Antigos (2000), realizado pela editora da Universidade Federal de Minas Gerais (UFMG); a primeira e segunda edições de Huni Kuĩnẽ Miyui (2002), uma coletânea de histórias tradicionais kaxinawá com prefácio e apresentação em português e francês realizada para um

2 Esta informação pode parecer básica porém, através do contato prévio realizado com a instituição, constatou-se a ausência de dados atualizados e sistematizados sobre o acervo e seus títulos.
Figura 37: A

pesquisadora em frente ao CDPI. Fonte: Pesquisa de campo, Paiva (2019).

Figura 38: Área interna do prédio, onde está arquivada boa parte do acervo de impressos. Fonte: Pesquisa de campo, Paiva (2019). 
lançamento especial em Genebra e editados pelo Ministério da Educação. Nestes livros, o copyright é creditado à CPI-AC ou à OPIAC mas a edição fica a cargo da respectiva entidade. Estes volumes também não eram voltados para a utilização nas salas de aula indígenas, fator que determinou a não inclusão dos mesmos nos dados apresentados a seguir.

Não foram considerados, também, alguns títulos que, apesar de publicados durante o projeto "Uma experiência de autoria dos índios do Acre", são assinados por membros da CPI-AC, pesquisadores e professores não-indígenas. São estes: a primeira edição ${ }^{3}$ de As Primeiras Letras (1991), uma cartilha de pré-alfabetização em cuja página de créditos consta "organização, elaboração e revisão do material: Vera Olinda Sena e Nietta Monte", ou seja, o material, apesar de ilustrado pelos professores indígenas, foi desenvolvido por Sena e Monte; e Cerâmica Indígena (a publicação não possui data, mas, segundo dados da CPI-AC, estima-se que seja de 1993), uma compilação de técnicas e peças produzidas em cerâmica por diversas etnias indígenas, que não possui créditos de autoria, apenas de organização.

Sendo assim, tem-se um total de 86 livros de autoria indígena, editorados pela CPI-AC e voltados para a utilização nas escolas indígenas do estado. A partir do exame das temáticas exploradas pelos volumes, assim como de suas características visuais gerais, pode-se propor uma categorização temática-visual dos títulos da Coleção. As categorias e subcategorias determinadas ${ }^{4}$ são apresentadas a seguir.

\section{Cartilhas de alfabetização}

Esta categoria reúne as cartilhas de alfabetização, em português e nas línguas indígenas de etnias específicas. $\mathrm{O}$ texto destes livros é composto, basicamente, na forma de enunciados, acompanhados de ilustrações e espaços em branco para a resolução do exercício proposto. Esta categoria engloba a maior parte das publicações, 36 no total, constituindo $41 \%$ da Coleção. Destas, 12 são cartilhas de alfabetização, pré-alfabetização e interpretação de texto em português, 24 são cartilhas de alfabetização em línguas indígenas (Jaminawa, Huni Kũ̃ / Kaxinawá, Manchineri / Manchineru, Yawanawá, Apurinã, Katukina, Poynawa, Shawadawa, Ashaninka.).

\section{Disciplinas específicas}

Livros que, apesar de também denominados, muitas vezes, como cartilhas, se diferenciam das cartilhas de alfabetização por possuírem configurações gráficas mais variadas, apresentando tanto o modelo de exercícios ilustrados quanto textos mais longos. Os livros de geografia, por exemplo, se destacam pela rica utilização de mapas, sejam estes compostos mecanicamente ou ilustrados. Esta categoria conta com 17 volumes, configurando $20 \%$ do total de livros da Coleção. Entre estes, tem-se 7 livros de matemática (dos quais se destacam Hame Ayomatero, apostila de matemática ashaninka de 2000, e Yawanawahãu Tãnãty, apostila de matemática yawanawa, de 2010; os livros restantes são escritos por e voltados para diversas etnias em conjunto), 2 de história indígena e 8 de geografia.

3 A segunda edição do mesmo material foi considerada poise em sua página de créditos, apesar de não haver uma lista de autores, tem-se "levantamento dos textos e desenhos", o que implica que os textos foram selecionados pelos organizadores e provavelmente derivaram dos moentos de formação indígena (isso também é explicitado na apresentação do material).

4 As categorias foram criadas pela pesquisadora autora desta dissertação com base, hierarquicamente, nos temas abordados pelos livros, na quantidade de livros respectivos a determinada temática, e na configuração gráfica semelhante entre livros de um mesmo tema. Optou-se por não considerar categorias por etnia devido à grande quantidade de livros voltados para mais de um povo. 


\section{Gestão e Manejo do território}

Nesta categoria reúnem-se os livros voltados para o manejo de fauna e flora - que são, via de regra, fruto dos cursos de formação de agentes agroflorestais indígenas, que somam 9 títulos; 1 plano de gestão territorial; e duas edições do Atlas Geográfico Indígena, uma coletânea de mapas ilustrados que abordam não só aspectos geográficos, mas também históricos e culturais da ocupação do território acreano pela população indígena. $O$ total de 12 livros corresponde a $14 \%$ da Coleção.

\section{Artesanato e música}

Livros que tratam diretamente de levantamentos a respeito de cantos, técnicas de produção artesanais (por exemplo, a tecelagem kaxinawá), representações visuais tradicionais etc. São 9 títulos no total, que diz respeito a 10\% da Coleção, sendo a maior parte destes produzidos por pesquisadores kaxinawá.

\section{Livros de leitura}

Esta é a nomenclatura utilizada por Monte (1996) para descrever os livros compostos por coletâneas de contos, depoimentos, memórias, histórias e mitos indígenas. Alguns possuem exercícios de interpretação, enquanto outros são compostos apenas pelo texto corrido. A presença de ilustrações é comum. Esta é a menor categoria, com apenas 7 títulos (cerca de $8 \%$ do total), sendo 2 deles especificamente de histórias kaxinawá, 1 de histórias katukina, 1 manchineri, e 3 com histórias de várias etnias em conjunto.

\section{Outros temas}

Agrupa os títulos com temáticas que não se encaixam nas categorias anteriores, porém cuja quantidade de volumes produzidos não justifica a criação de uma nova categoria. Essa categoria é composta por 6 livros (7\% do total da Coleção), sendo 2 livros sobre pedagogia e didática, 1 voltado para o treinamento dos agentes de saúde, e 2 edições de Plantas Medicinais - Doenças e Curas do Povo Huni Kuĩ, um levantamento de plantas e técnicas de medicina tradicional kaxinawá.

Os dados quantitativos referentes a cada categoria permitem perceber que a alfabetização era o grande carro-chefe do projeto de educação da CPI-AC. De fato, grande parte do material analítico produzido a respeito dos livros e do programa de educação em si tratam especificamente de compreender e discutir as estratégias didáticas de letramento e os processos linguísticos de configuração escrita das línguas indígenas das etnias atendidas pela entidade.

\footnotetext{
Gráfico 1: Gráfico demonstrativo das quantidades de cada categoria na composição total da Coleção Autoria Indígena. Fonte: Adaptação da autora a partir de dados da pesquisa de campo, Paiva (2019).
}

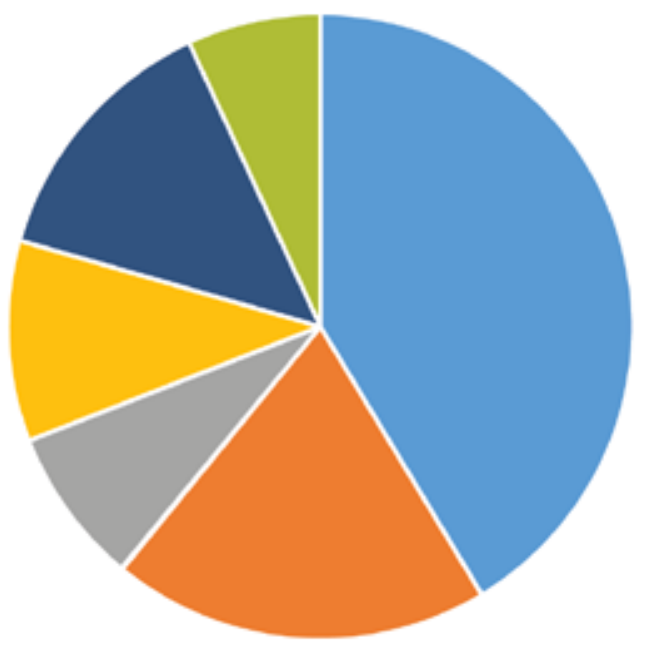

CATEGORIAS TEMÁTICAS DA COLEÇÃO AUTORIA INDÍGENA

\begin{tabular}{|lll}
\hline $41 \%$ & 36 & Cartilhas de alfabetização \\
\hline $20 \%$ & 17 & Disciplinas específicas \\
$14 \%$ & 12 & Gestão de manejo do território \\
$10 \%$ & 9 & Artesanato e música \\
$8 \%$ & 7 & Livros de leitura \\
$7 \%$ & 5 & Outros \\
\hline
\end{tabular}

TOTAL: 86 LIVROS 

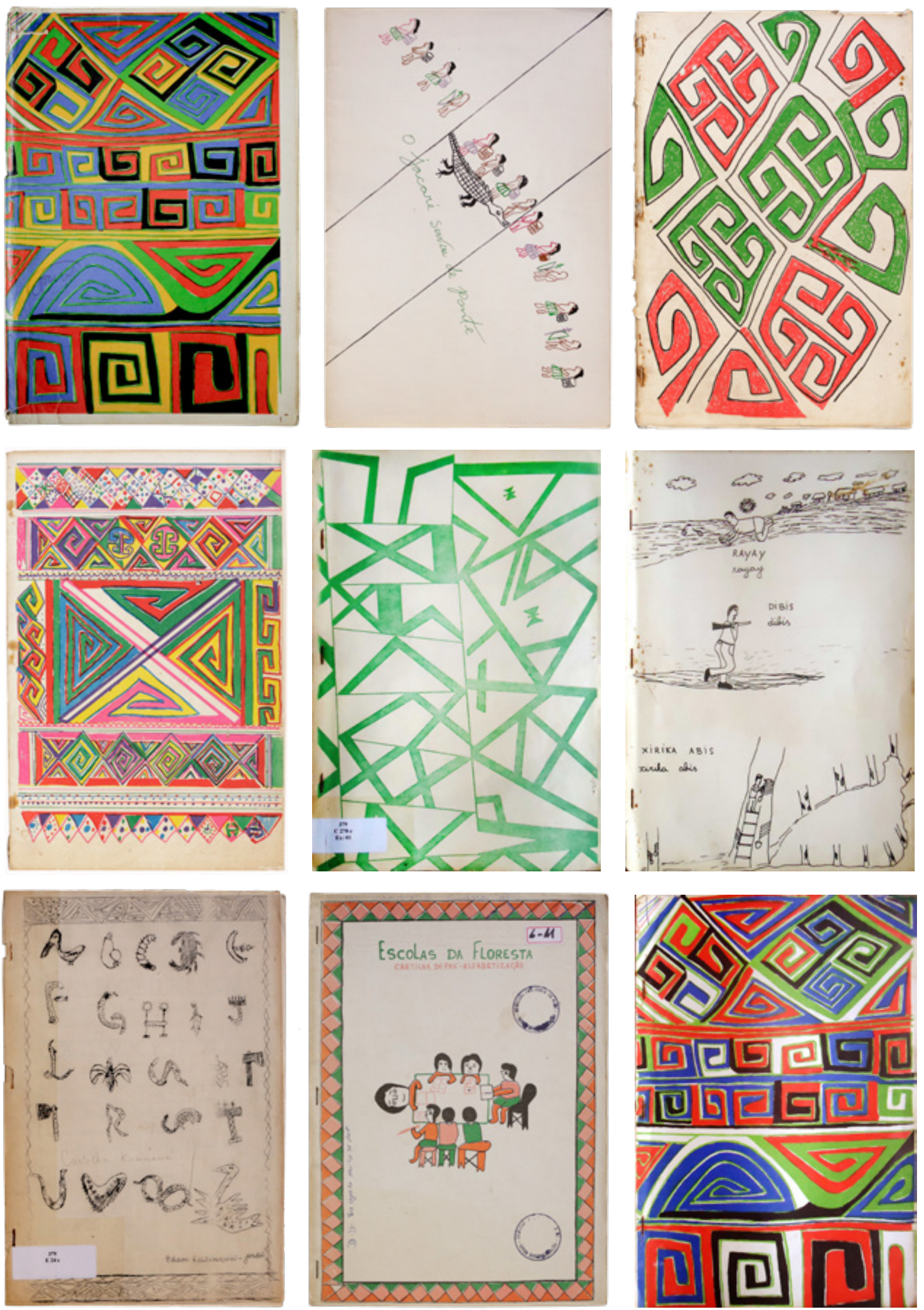

Figura 39: Capas de livros publicados pela CPI-AC entre 1983 e 1989. Da esquerda para a direita, de cima para baixo: Cartilha do índio Seringueiro (1983), O Jacaré Serviu de Ponte - Estórias de Hoje e de Antigamente (1984), Fábrica do índio (1985), Escolas da Floresta (1986), Cartilha Jaminawa (1988), Cartilha da Língua Shamenawa (1989), Cartilha Kaxinawá (sem título na capa, 198-), Escolas da Floresta - Cartilha de Pré-Alfabetização (198-) e Cartilha Kaxinawá: Hãtxa Huni Kuĩ (1989, possui a mesma capa da Cartilha do índio Seringueiro). Fonte: Pesquisa de campo, Paiva (2019). 
A atenção dada aos levantamentos culturais também é interessante, especialmente ao considerar-se a riqueza de temas abordados. Já na primeira leva de livros produzidos encontram-se: Fábrica do Índio, um levantamento de cultura material e práticas artísticas e culturais tradicionais das etnias Kaxinawá, Katukina, Apurinã, Puyanawa, Jaminawa, Manchineri, Yawanawa e Kaxari, com registros fotográficos e um pequeno dicionário de "Classificação e nomes artesanato" em Apurinã, Katukina e Kaxinawá; e O Jacaré Serviu de Ponte - Estórias de Hoje e Antigamente, uma coletânea de histórias e relatos dos tempos pré e pós-contato, o primeiro livro de leitura produzido. Os livros de leitura, apesar de não abundantes quantitativamente, se constituem como uma categoria de grande relevância dentro da coleção, diante de seu papel fundamental para a manutenção da memória cultural indígena, trazida para a escola por meios desses títulos (Monte, 1996).

Entre 1983 e 1989 foram lançados 10 livros, cerca de 12\% do total, o que se justifica ao compreender-se o início do projeto, as dificuldades de produção técnica e de captação de recursos. A maior parte dos livros (57\%) foi lançada entre 1990 e 1999, no período em que havia uma gráfica interna da CPI-AC, possibilitando que a equipe da entidade se responsabilizasse por todas as etapas de produção e minimizando os custos. Cerca de $35 \%$ dos livros foram produzidos entre 2000 e 2008, quando outros projetos, além da formação de professores, passaram a render publicações, tais como os planos de gestão territorial e os livros de manejo advindos do curso de formação de agentes agroflorestais.

Os períodos temporais de produção dos livros possuem especificidades interessantes, que auxiliam a compreensão da história da Coleção. Com isto em mente, e através das entrevistas realizadas e dos registros presentes nos livros e materiais produzidos, alguns aspectos relevantes respectivos a cada período são compilados a seguir.

\subsection{De 1983 a 1989: aprender fazendo}

A ideia de se produzir uma cartilha específica para a utilização dos professores em formação surge no momento da realização do primeiro curso de formação de professores, e sua produção não havia sido prevista no orçamento do projeto original, demandando a angariação posterior de recursos (Monte, 1996). Levando-se em conta a necessidade de uma tiragem grande para atender às escolas das etnias Kaxinawá (do rio Jordão e do rio Envira), Apurinã, Katukina, Jaminawa, Manchineri e Yawanawa, o planejamento gráfico dos livros tinha como direcionamento principal a maximização dos recursos obtidos. Ao falar sobre estes primeiros anos, tanto no texto de Monte (1984), reproduzido a seguir, quanto nas entrevistas realizadas com membros mais antigos da equipe da CPI-AC, é comum ouvir a expressão "aprendemos fazendo", "aprendemos na prática, ou variações dessa ideia.

Aprendemos ensinando: os alunos, futuros monitores, davam aulas entre si, aprendendo a ensinar. Nós, ensinando pela primeira vez a outro povo, com quem tínhamos muito a aprender. Por isso ensinamos aprendendo, ouvindo, deixando-os falar, escrever, contar suas histórias.

Aprendemos inventando um material de ajudar a ensinar nas suas comunidades. Primeiro, criamos a cartilha de alfabetização com desenhos e palavras dos monito- 
Figuras 40 e 41: Primeira e quarta capas da Cartiha do Índio Seringueiro (1983), a primeira publicação da CPI-AC. A quarta capa era aproveitada para incluir conteúdos do miolo. Fonte: Pesquisa de campo, Paiva (2019). res. A invenção ficou bonita, conseguimos dinheiro para fazer mil delas com a Oxtan. Hoje, ela virou cartilha mesmo e já está ensinando a ler, escrever nas primeiras escolas, com monitores indígenas do Acre. (MONTE, et al., 1984, s/ d.)

Os primeiros dois livros publicados pela CPI-AC derivam da realização do primeiro curso de formação: uma cartilha de alfabetização, a Cartilha do índio Seringueiro (1983); e uma "cartilha de pós-alfabetização" (MONTE In CABRAL et al., 1987), que posteriormente Monte chamaria de "livro de leitura" (Ibid.), O Jacaré Serviu de Ponte - Estórias de Hoje e de Antigamente (1984). Se a Cartilha do índio Seringueiro cumpriria o papel importante de auxiliar a alfabetização dos alunos indígenas em português, O Jacaré Serviu de Ponte tinha como objetivo trabalhar a prática da leitura concomitantemente à disseminação, registro e conhecimento de mitos, histórias e memórias do "tempo das malocas" (KAXINAWÁ, et al., 199-). Já para o ensino de matemática, optou-se por utilizar a cartilha Poronga, produzida pelo CEDI.

As cartilhas foram produzidas de modo quase experimental, já que ficou a cargo da equipe de educação da CPI-AC a produção gráfica dos layouts para impressão. Na Cartilha do índio Seringueiro (1983) o texto foi totalmente escrito à mão, e as ilustrações feitas pelos autores reproduzidas manualmente. Essa etapa aparece creditada como "transcrição gráfica", tópico que se manteria presente por muito tempo nas publicações futuras. Já em O Jacaré Serviu de Ponte contratou-se uma empresa para realizar a diagramação do material, informação que consta na folha de créditos. O livro possui um projeto gráfico melhor delimitado, com margens constantes e texto composto em tipografia sem serifa, com títulos em caixa alta.
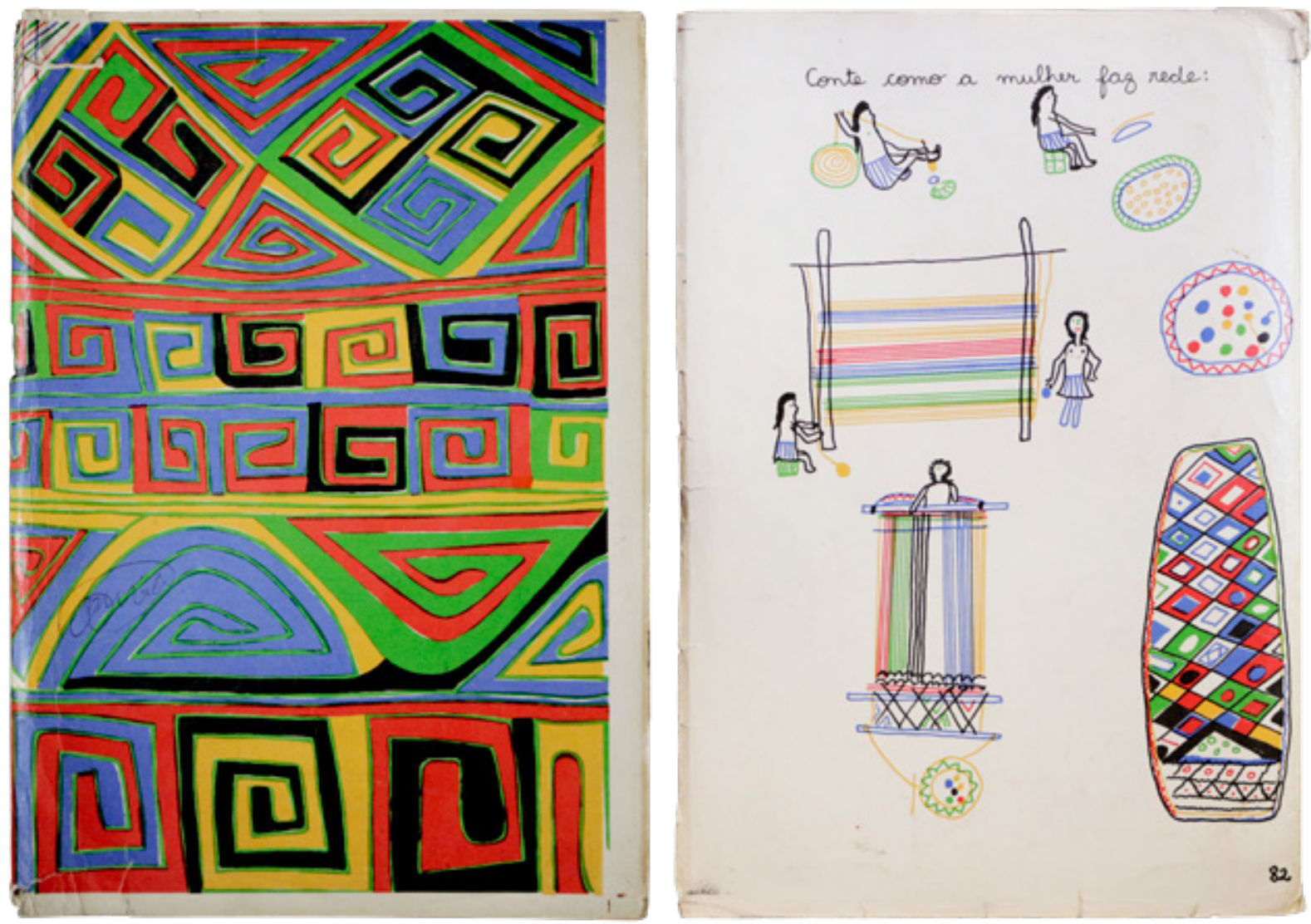

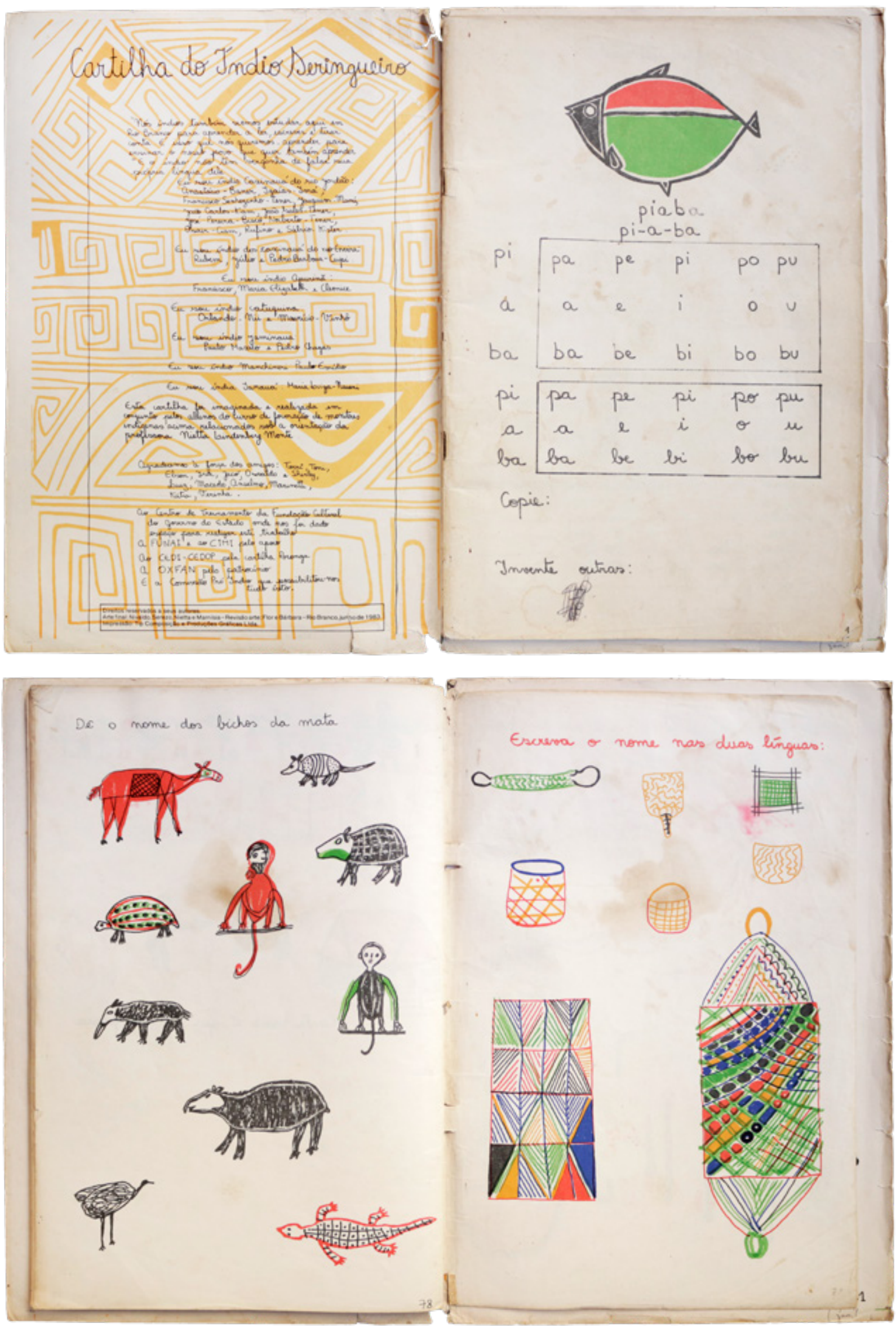

Figuras 42 e 43: Segunda capa e páginas do miolo da Cartiha do Índio Seringueiro (1983). O conteúdo textual da cartilha foi todo escrito à mão. Fonte: Pesquisa de campo, Paiva (2019). 

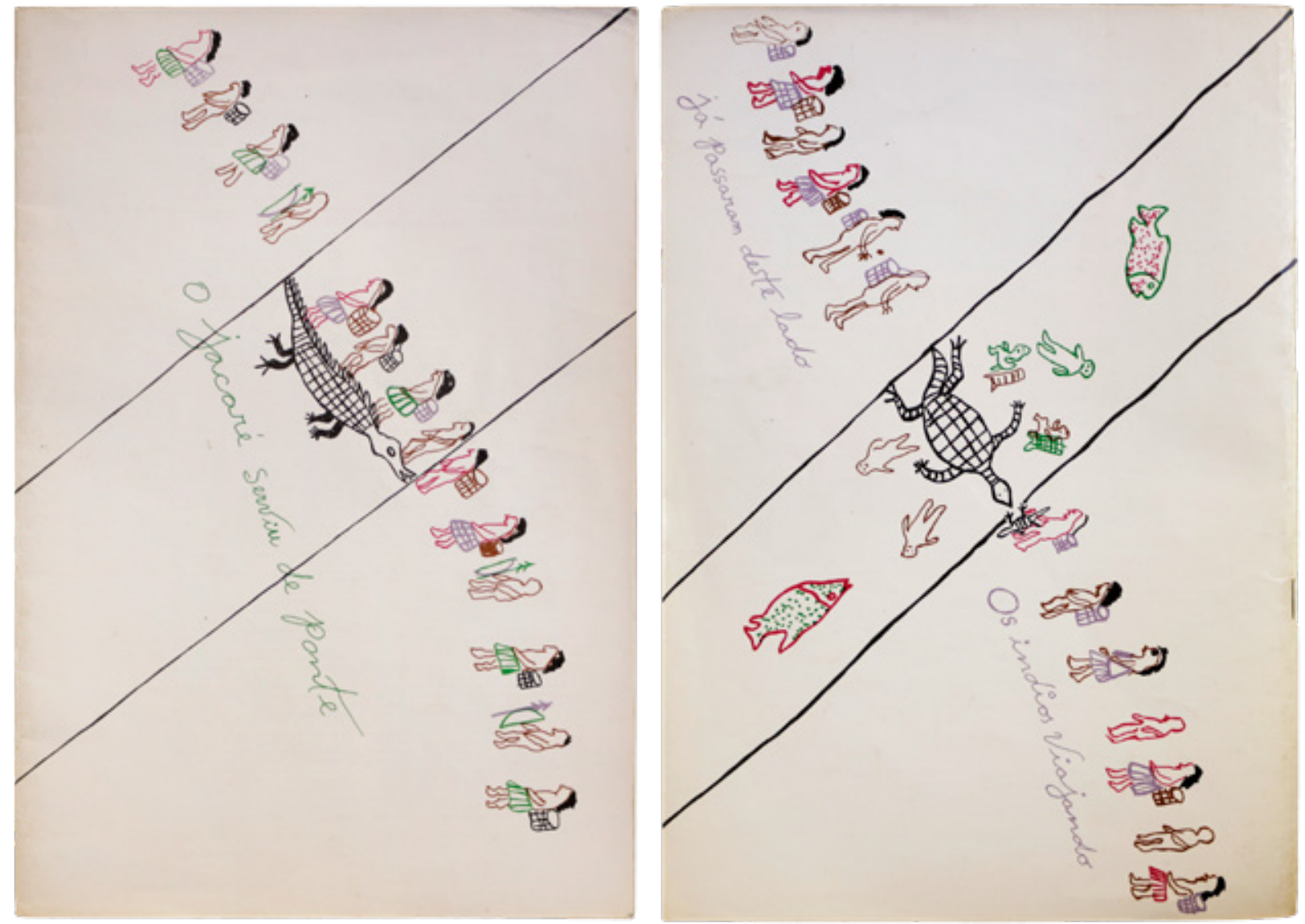

Figuras 44 e 45:

Primeira e quarta capas de $O$ Jacaré Serviu de Ponte - Estórias de Hoje e de Antigamente

(1983), a primeira publicação da CPI-

AC. A quarta capa era aproveitada para incluir conteúdos do miolo.

Fonte: Pesquisa de campo, Paiva (2019).
Olha, pra tu ter uma ideia, já tem livro de 1985 e livro de 1997 que já foram assim contratados designers gráficos para fazer um projeto. Mas mesmo assim, o de 1983 e o de 1985 eram livros que foram com designer gráfico mas ele só pegava a folha que o índio tinha feito e praticamente levava pro livro, que é aquela Piaba [Cartilha do indio Seringueiro], a primeira cartilha, ela era assim manuscritazinha e só foi montar o projeto, sei lá, pra imprimir. E o livro, o segundo livro, O Jacaré Serviu de Ponte, esse já foi com projeto gráfico, mas tu percebe que o projeto gráfico era um projeto gráfico que não podia mexer em nada. Era pegar o desenho, botar tal e qual, e os textos eram batidos à máquina. (SENA, 2019)

Essas duas primeiras publicações foram responsáveis por proporcionar à equipe da CPI-AC uma experiência prática com os processos técnicos da produção de livros impressos, e é interessante perceber que, mesmo neste primeiro momento, já havia a intenção de manter os processos diretamente nas mãos da equipe interna da entidade.

As cartilhas seguintes acabaram por seguir o modelo desenvolvido pelas duas primeiras publicações: do ponto de vista do material, tinham, em geral, formato ofício, encadernação com grampos, papel offset comum para o miolo e papel cartão de gramatura um pouco maior para as capas (às vezes laminados, às vezes não). Outra característica interessante são as capas, exclusivamente compostas por ilustração - algumas inclusive sem nenhuma informação verbal complementar.

Deste período também datam: Fábrica do Índio (1985), conforme mencionado anteriormente, um levantamento de cultura material de diversas etnias e também o primeiro material a conter fotografias - em conjunto com as ilustrações; Escolas da Floresta (1986), uma coletânea de reflexões feitas pelos professores indígenas a respeito de questões relacionadas ao 

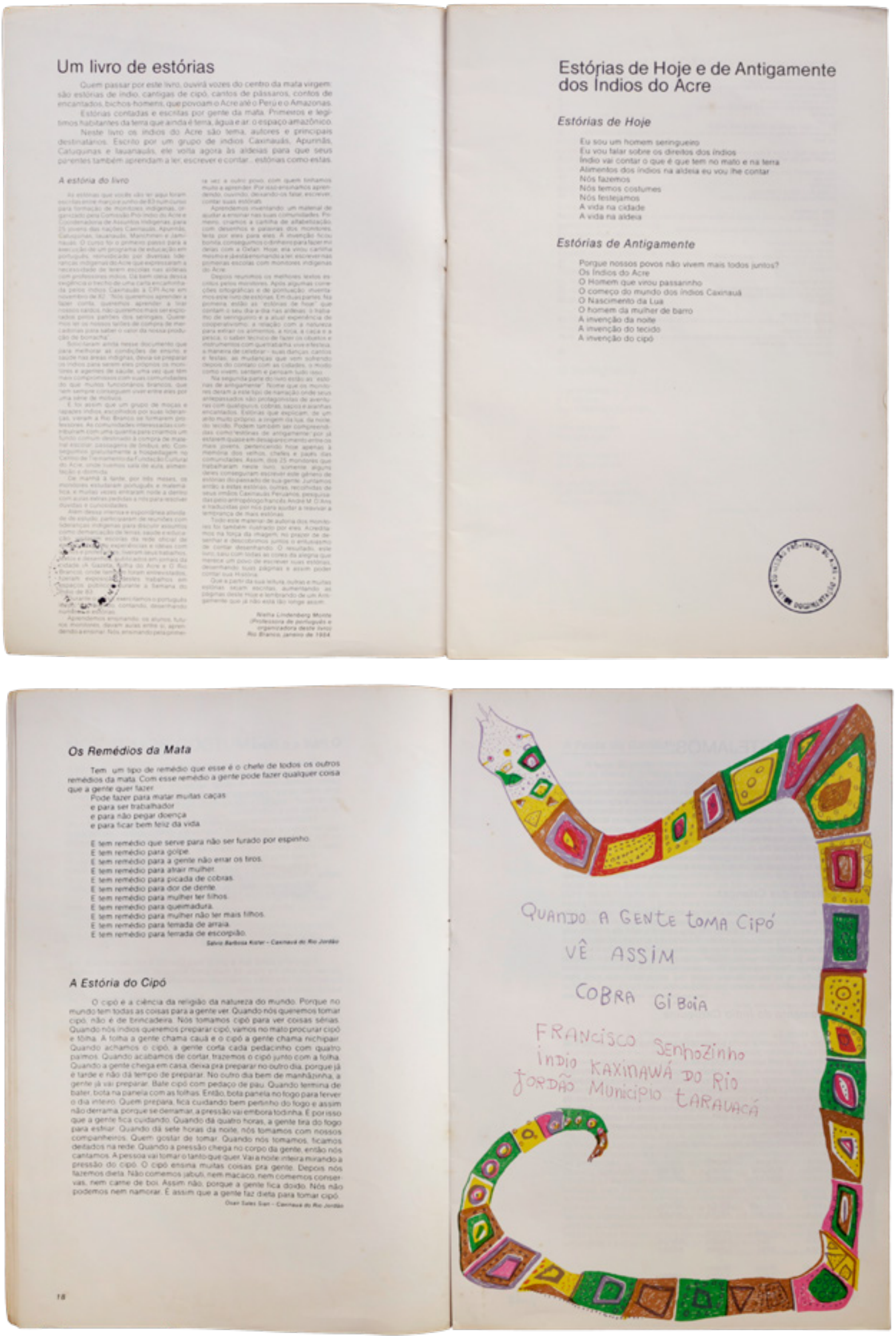

Figuras 46 e 47: Segunda capa e páginas do miolo de O Jacaré Serviu de Ponte - Estórias de Hoje e de Antigamente (1983). Margens generosas, ênfase para as ilustrações coloridas e tipografia sem serifa marcam o projeto gráfico da coletânea de narrativas. Fonte: Pesquisa de campo, Paiva (2019). 

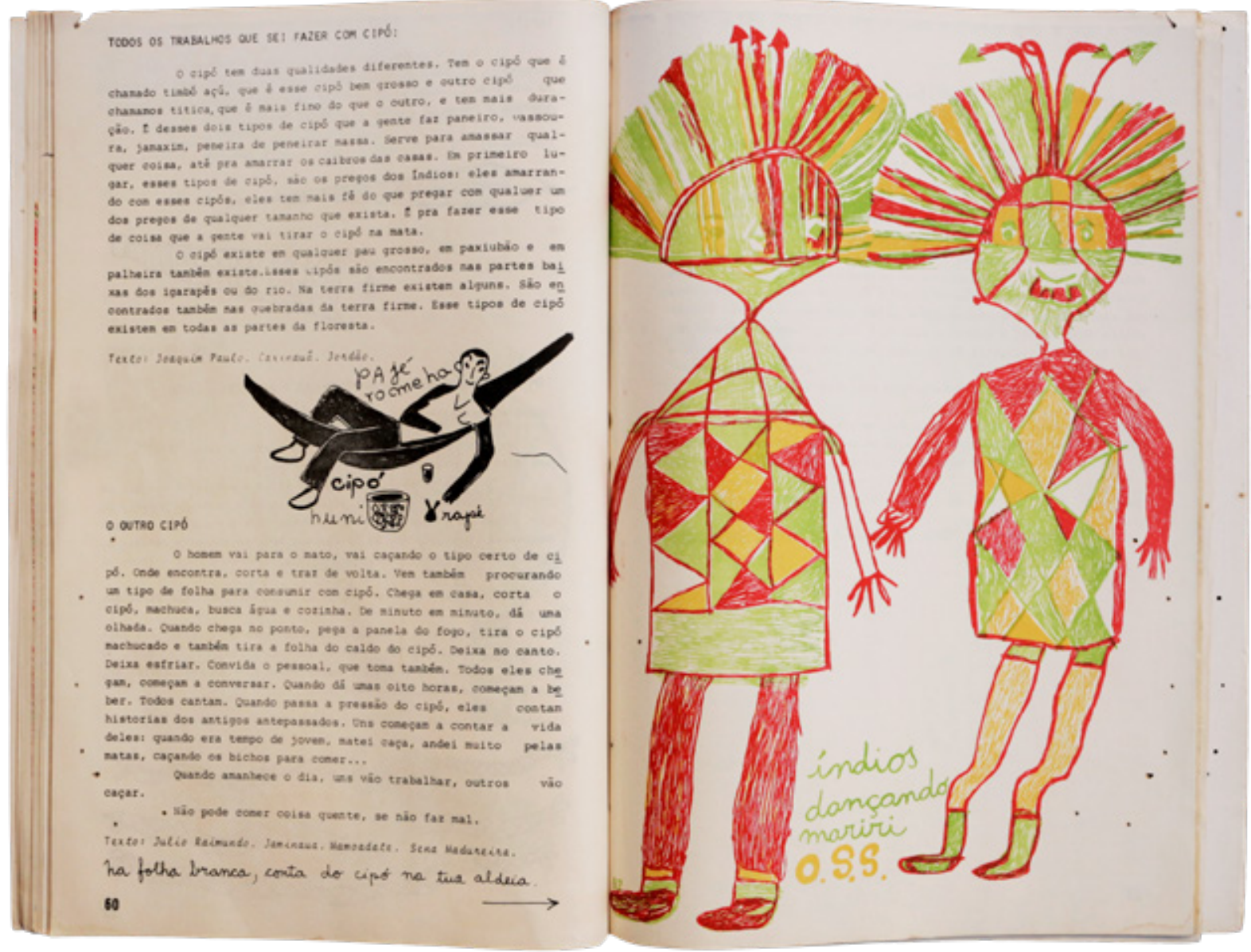

Figura 48: Páginas do miolo de Fábrica do índio (1985). Neste livro, o texto foi batido à máquina de escrever e é intercalado com pequenas ilustações monocromáticas e grandes ilustrações a cores. Fonte: Pesquisa de campo, Paiva (2019). letramento e à escola; e três cartilhas de alfabetização em língua indígena: a Cartilha Jaminawa (1988), a Cartilha Kaxinawá: Hãtxa Huni Kũ̃ (1989) e a Cartilha da Língua Shamenawa (1989). Estas duas últimas, assim como muitas outras publicações até meados da década de 1990, aproximadamente, não possuem data de publicação registrada no próprio livro. De acordo com o acervo da CPI-AC, ambas foram produzidas entre 1988 e 1989.

Nas páginas de créditos das primeiras cartilhas em língua indígena encontra-se pela primeira vez a marca da Gráfica Povos da Floresta: Zeno Santiago. Segundo as entrevistas realizadas, estipula-se que esta era a marca utilizada pela gráfica compartilhada entre a CPI-AC e o Centro dos Trabalhadores da Amazônia (CTA $)^{5}$. Posteriormente, cada entidade viria a ter seu próprio setor gráfico interno, a Gráfica Kene Hiwe e a Gráfica Poronga, respectivamente. Esta constatação está atrelada ao crédito de Nivaldo Mônaco como arte finalista dos materiais. Nivaldo foi o profissional responsável pela gráfica do CTA e que, antes da aquisição da impressora offset pela CPI-AC, prestou alguns serviços para a entidade, segundo informações de Ecio Rodrigues, coordenador geral do Centro entre 1991 e 1998. Infelizmente não foi possível precisar quem seria Zeno Santiago.

Os materiais publicados nesse período são graficamente semelhantes, com o texto via de regra justificado, batido à máquina, e ilustrações. Nas apostilas, exercícios alternados com ilustrações menores compõem boa parte das páginas, enquanto nos outros livros é comum encontrar ilustrações de página completa. A configuração visual desses primeiros impressos ditaria o tom geral da produção editorial da CPI-AC nos anos seguintes.

5 ONG parceira da CPI-AC, também sediada em Rio Branco, voltada para o desenvolvimento de projetos que promovam educação, saúde, desenvolvimento econômico e cultural e direitos humanos em comunidades de seringueiros e outros trabalhadores da floresta amazônica. 

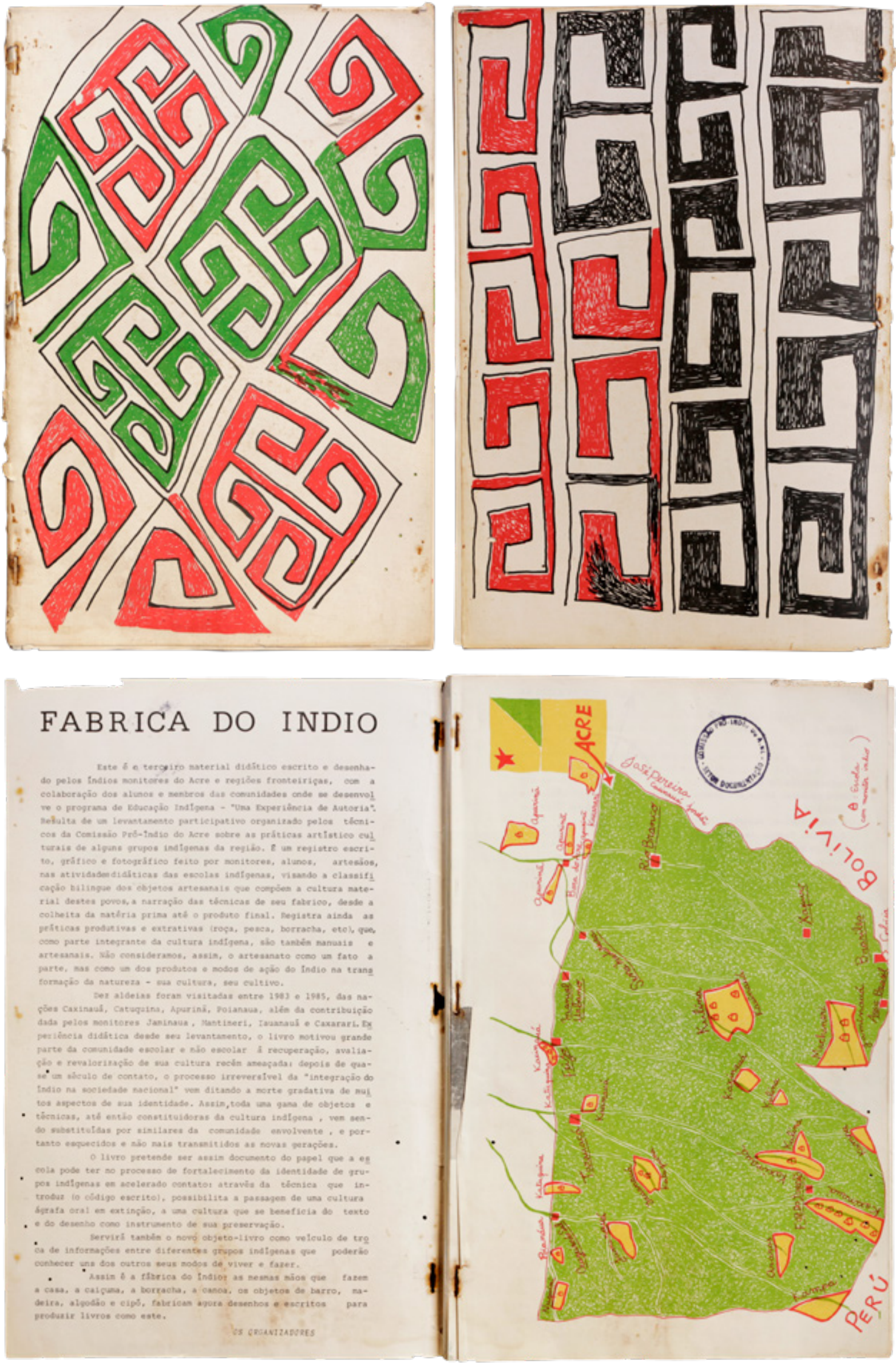

Figuras 49 e 50: Primeira capa, quarta capa, segunda capa e primeira página do miolo de Fábrica do índio (1985).

Fonte: Pesquisa de campo, Paiva (2019). 

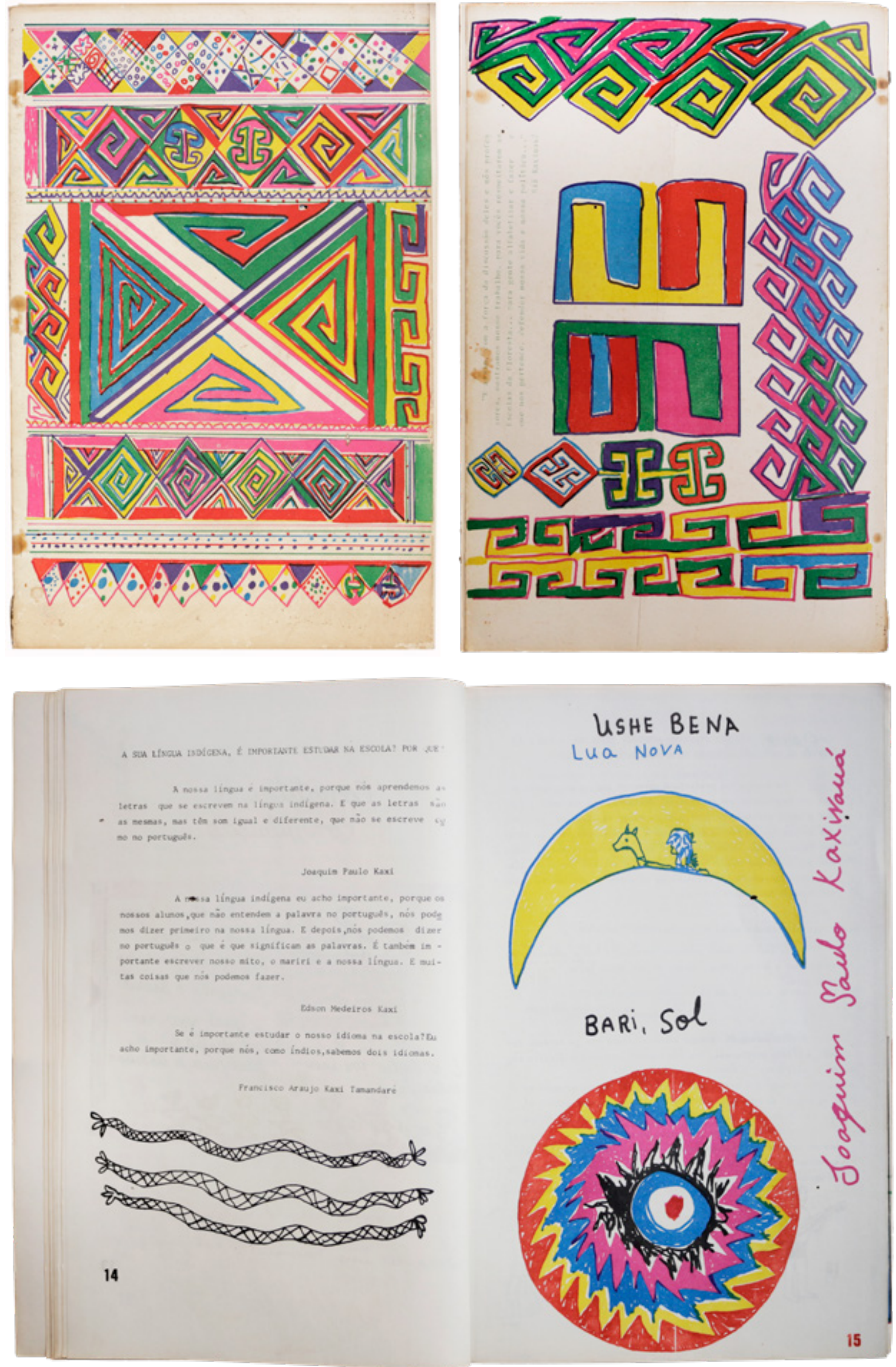

Figuras 51, 52 e 53: Primeira capa, quarta capa e páginas do miolo de Escolas da Floresta (1986). Fonte: Pesquisa de campo, Paiva (2019). 

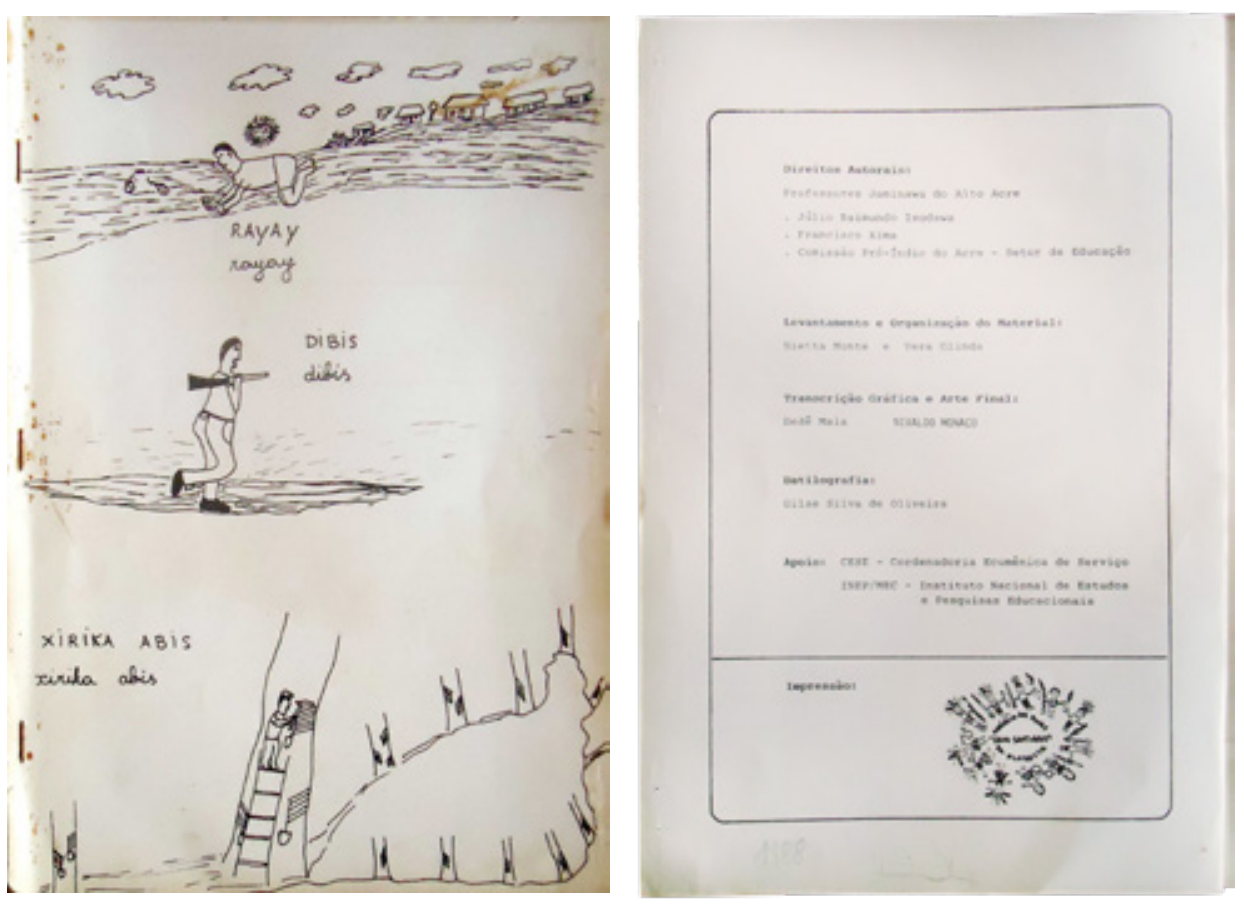

Figuras 54 e 55:

Primeira capa e segunda capa (comumente utilizada como página de créditos nos livros dessa época) da Cartilha Jaminawa (1988). Fonte: Pesquisa de campo, Paiva (2019).

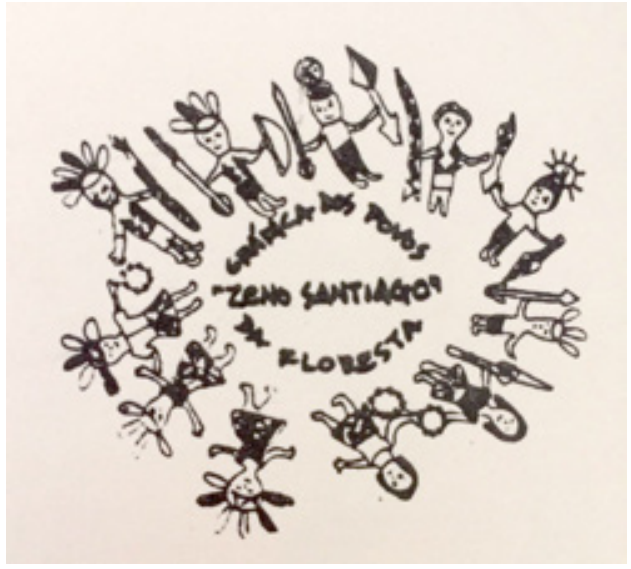

Figura 56: Detalhe com a marca da Gráfica Povos da Floresta Zeno Santiago na Cartilha Jaminawa (1988). Fonte: Pesquisa de campo, Paiva (2019).

\subsection{De 1990 a 1999: a Gráfica Kene Hiwe}

No final da década de 1980 a CPI-AC adquiriu uma impressora offset e contratou um gráfico para que a produção dos livros pudesse ser realizada internamente. A primeira vez que o "setor gráfico da CPI-AC" consta nos créditos de impressão de um material é em 1991, na Cartilha YawanawaWixi Tapiwe. Porém, como algumas publicações anteriores não apresentam créditos de impressão, é difícil precisar o ano exato em que a gráfica interna entra em funcionamento. Mesmo com a internalização da produção, a maximização dos recursos e a busca por alternativas econômicas na configuração dos livros continua sendo um ponto chave de sua elaboração.

A proposta era ter grandes produções de materiais a preços econômicos, porque a gente não tinha recurso para fazer as edições. Então era muito simplificado, a gente que fazia tudo. A gente montava, fechava, depois grampeava. A gente ficava vendo modos de melhorar a resistência, ter uma capa mais resistente, mas sempre na economia. Não tinha a pretensão de fazer livros, assim, livros que eram muito mais caros. Porque as aldeias não tinham, as escolas não tinham nenhum material. Então, a gente trabalhava nesse sentido. (GAVAZZI, 2019) 

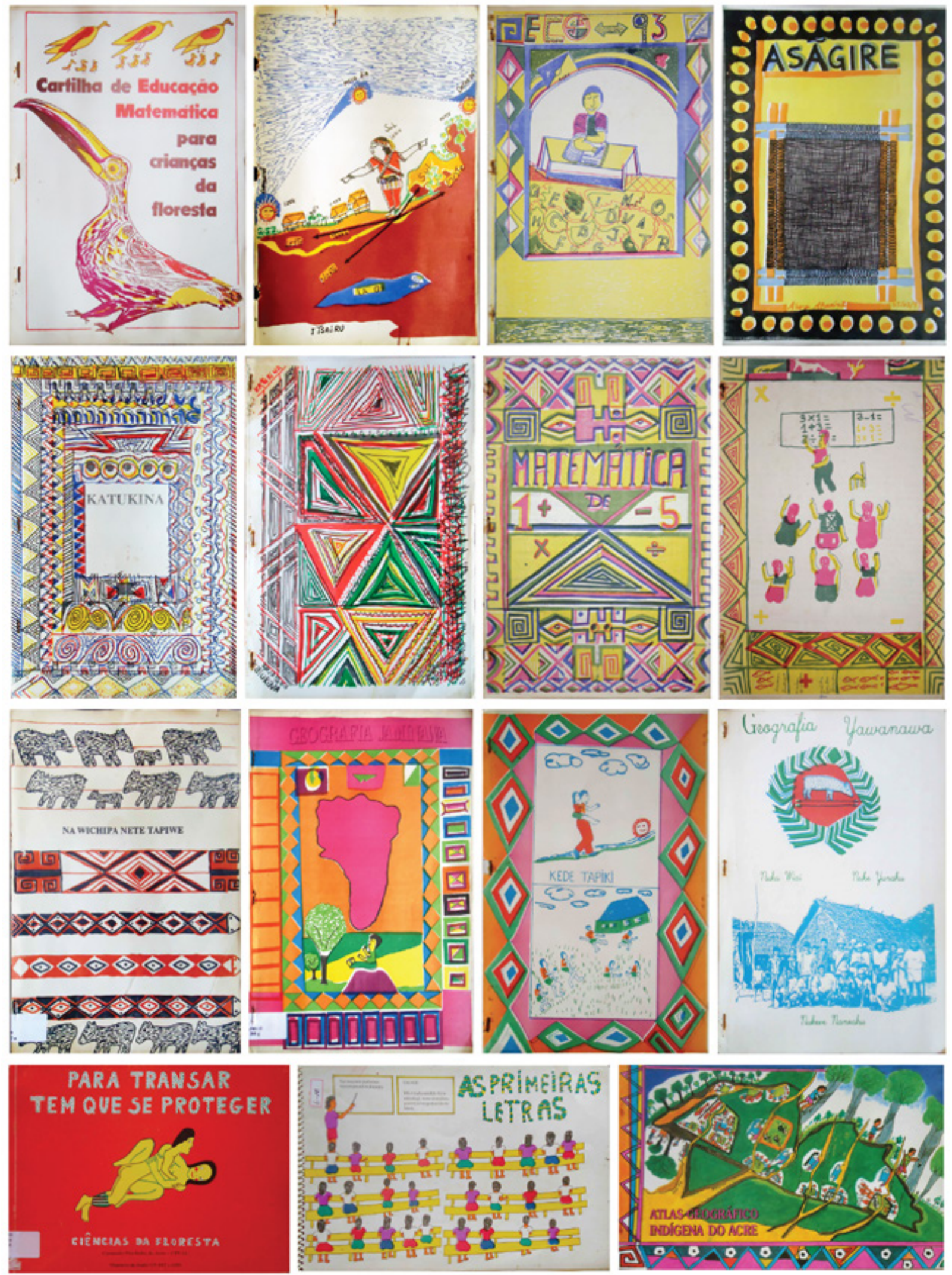

Figura 57: Capas de livros publicados pela CPI-AC entre 1990 e 1999. Da esquerda para a direita, de cima para baixo: Cartilha de Educação Matemática para Crianças da Floresta (1990), Cartilha de Geografia - Geografia Indígena (1992), Aprendendo Português nas Escolas da Floresta (1993), Asãgire (1993), Cartilha Katukina (1993), Cartilha Katukina (1993), Livro de Matemática 1 (1993), Livro de Matemática 2 (1993), Na Wichita Nete Tapiwe (1993), Geografia Jaminawa (1994), Geografia Jaminawa - Kede Tapiki (1994), Geografia Yawanawa (1994), Para Transar Tem que se Proteger - Ciências da Floresta (1999), As Primeiras Letras (1996), Atlas Geográfico Indígena do Acre (1996). Fonte: Pesquisa de campo, Paiva (2019). 
Os Kaxinawá do Acre e os livros da Coleção Autoria Indígena: uma análise em design editorial
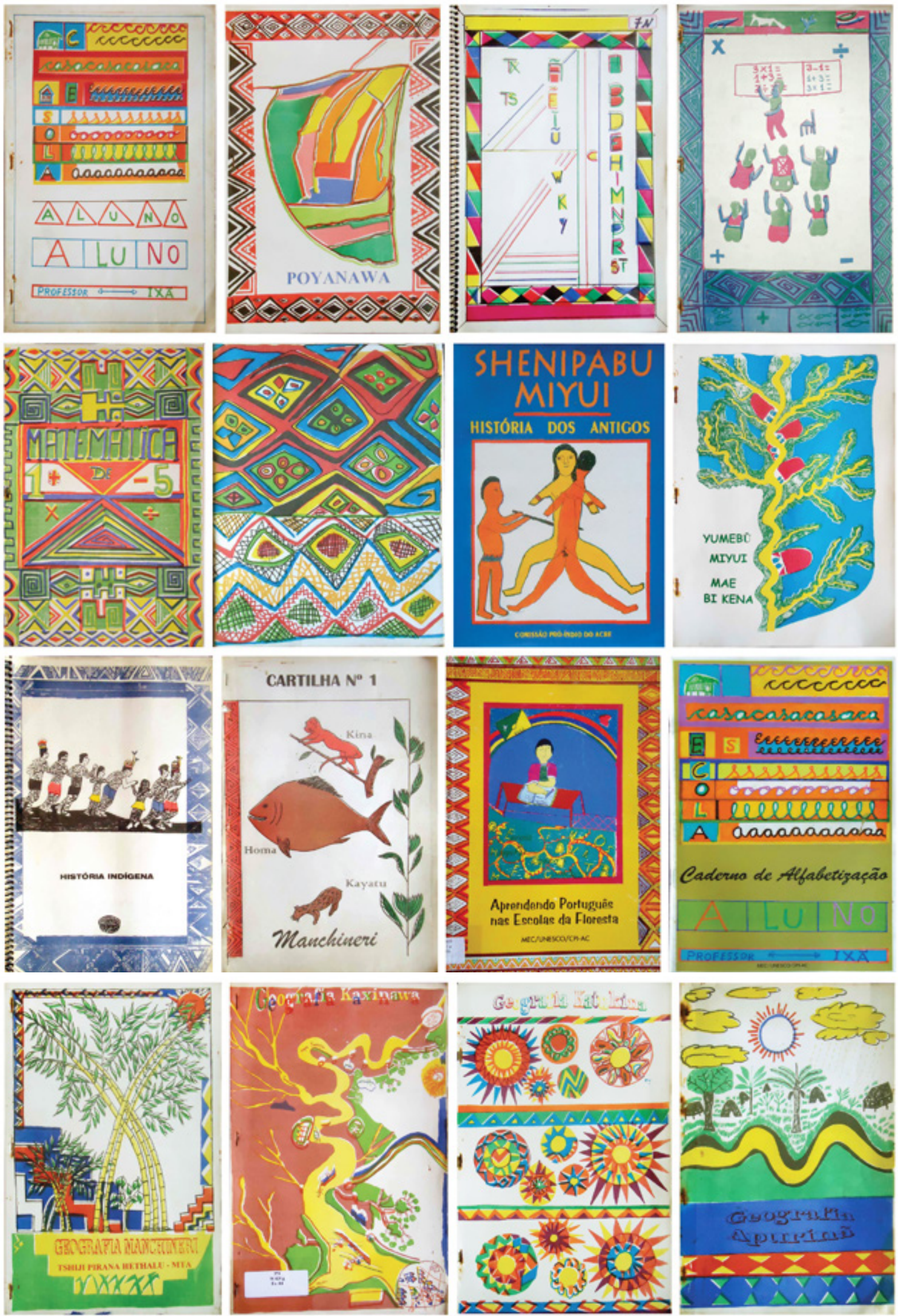

Figura 58: Capas de livros publicados pela CPI-AC entre 1990 e 1999. Da esquerda para a direita, de cima para baixo: Caderno de Alfabetização (1995), Cartilha Poynawa (1995), Cartilha Arara (1996), Livro de Matemática 12 ed. (1995), Livro de Matemática $22^{\circ}$ ed. (1995), Nukũ Mimawa (1995), Shenipabu Miyui - História dos Antigos (1996), Yumebũ Miyui - Mae Bi Kena (1997), História Indígena (1996), Cartilha No 1 Manchineri (1997), Aprendendo Português nas Escolas da Floresta $2^{\circ}$ ed. (1997), Caderno de Alfabetização $2^{\circ}$ ed. (1997), Geografia Manchineri (1994), Geografia Kaxinawá (1994), Geografia Katukina (1994), Geografia Apurinã (1994). Fonte: Pesquisa de campo, Paiva (2019). 
Figuras 59 e 60: llustração original para a capa do Livro de Matemática 1 (1993) e uma das folhas de papel vegetal utilizadas para a gravação das matrizes de impressão.

Fonte: Pesquisa de campo, Paiva (2019).

Figuras 61 e 62: Folhas de papel vegetal utilizadas para a gravação das matrizes de impressão. Cada

folha corresponde a uma das cores utilizadas na impressão. No detalhe percebe-se a anotação que indica a cor na qual esta matriz

será reproduzida (no

caso, verde claro)

Fonte: Pesquisa de campo, Paiva (2019).
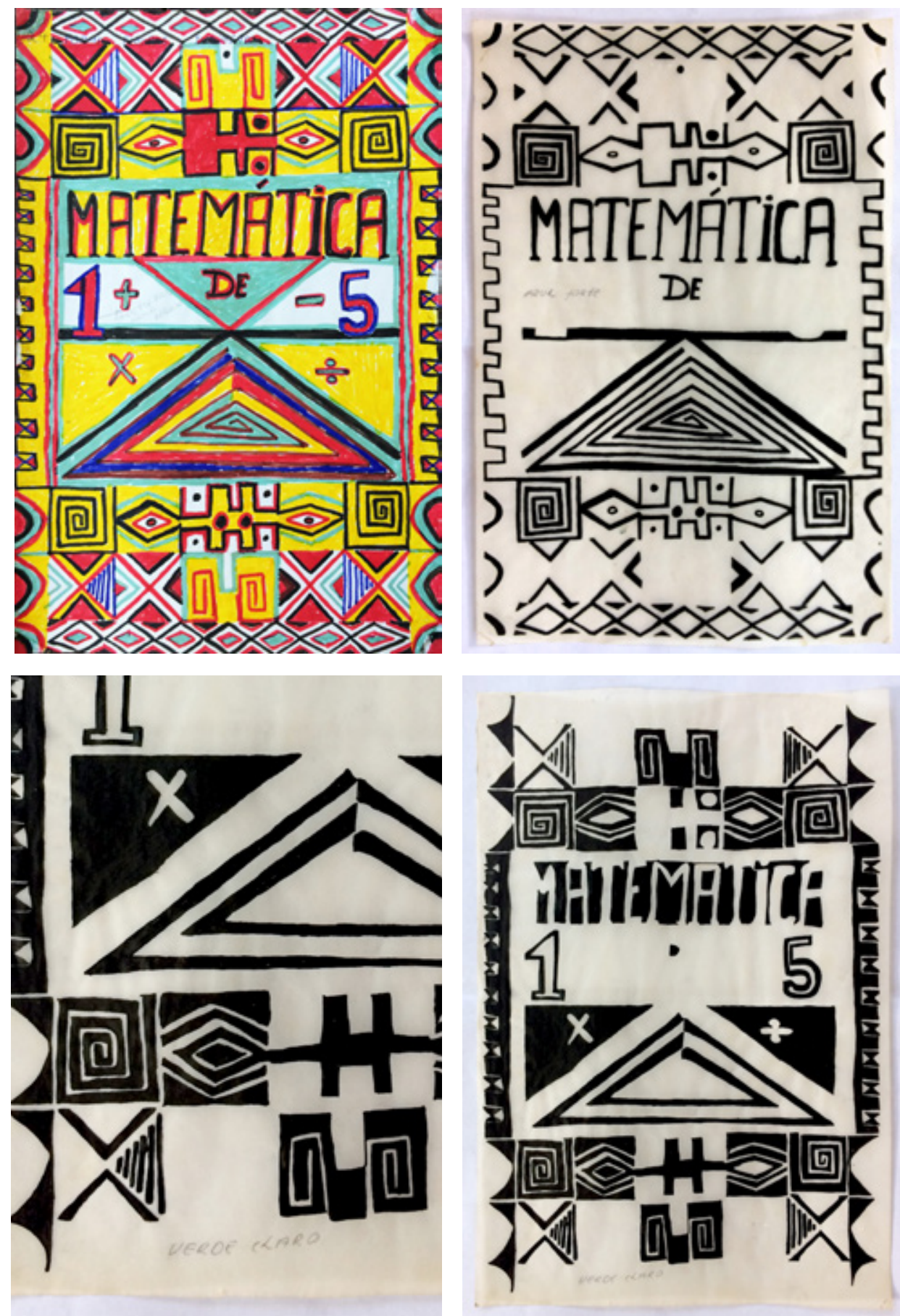

Numa cartilha para agentes de saúde produzida também em 1991 aparece pela primeira vez o nome de Jânio Ferreira ${ }^{6}$ e sua irmã, Altina Ferreira, como responsáveis pela diagramação do material. Jânio foi o gráfico da CPI-AC até o final da década de 1990 e, com a assistência de Altina, foram responsáveis pela maior parte dos materiais impressos nesse período, assim como pela "transcrição gráfica" das ilustrações, e parte da diagramação.

Comecei a trabalhar lá em 1987, comecei a trabalhar na produção de material didático dos índios, na parte de produção mesmo do material gráfico, das cartilhas, os desenhos eles faziam. Do desenho a gente tinha que

6 Jânio continua atuando como especialista em impressão e, após encerrar sua experiência com a CPI-AC no final da década de 1990, abriu sua própria gráfica, onde trabalha até hoje, no bairro Bosque da cidade de Rio Branco. 


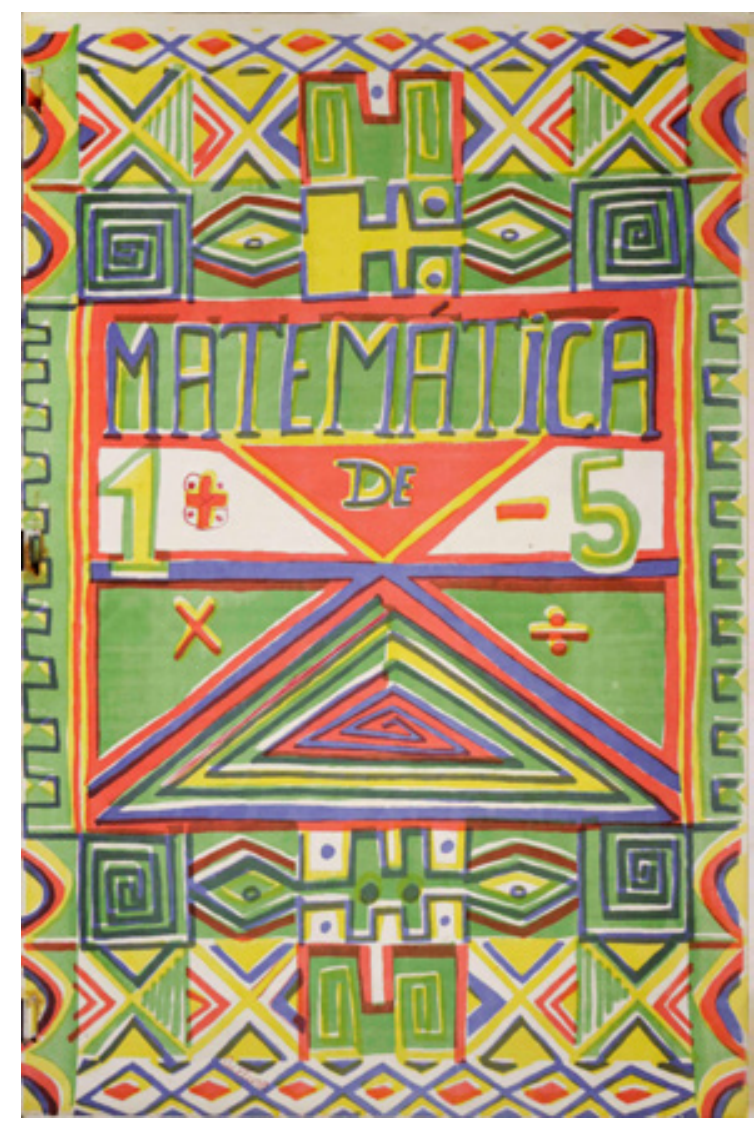

fazer a separação de cores. Eram muito coloridos os desenhos. Dava uma trabalheira. Aí você tinha que fazer várias matrizes. Por exemplo, tinha página lá que tinha 6 cores, 8 cores, em um desenho apenas. Cores variadas, eram tons de laranja, um tom de laranja claro, um tom de laranja mais escuro, um preto um cinza... então a gente tinha que fazer, pra botar nas cartilhas. Era tudo muito colorido. O índio, ele trabalha muito com cor. (FERREIRA, 2019)

“Transcrição gráfica" foi a forma encontrada para nomear o processo de reprodução das ilustrações produzidas pelos professores indígenas em formação em papel vegetal, para que se pudesse gravar as matrizes. Ou seja, as ilustrações eram produzidas, juntamente aos textos, nos momentos de formação, e posteriormente reproduzidas em papel vegetal por membros da equipe ${ }^{7}$, já em sua formatação para impressão (com o tamanho adequado para a diagramação e a separação de cores).

Sim, a gente tinha uma gravadora de chapa long run e uma maquininha datec. Uma datec de mesa. Botava o vegetal em cima, uma luz passa por baixo na máquina e aí ela vai gravando a chapa. Aí você fixa ela no fixador, que é uma lâmpada com uma voltagem bem incandescente, bem forte. E aí você segurava a chapa. (FERREIRA, 2019)

As publicações produzidas internamente continuam a seguir o modelo da primeira cartilha, com algumas modificações devido às possibilidades técnicas dos equipamentos disponíveis. O formato é ajustado para ofício e

\section{Figuras 63 e 64:}

Primeira e quarta capas do Livro de Matemática 1 (1993). Percebe-se a fidelidade à ilustração original. Fonte:

Pesquisa de campo, Paiva (2019).

7 Apesar de os nomes de Jânio e Altina serem os mais comumente creditados pela transcrição gráfica dos desenhos nesse período, nos livros lançados na entre 1983 e 1986 também encontram-se os nomes de Djacira Maia, Bárbara Vicuña e Kátia Simone Bichara. 
as folhas passam a ser grampeadas como um maço de folhas empilhadas, ao invés dos grampos canoa utilizados nas primeiras publicações, impressas em gráficas externas.

Então, tudo que tu ia fazer, tu tinha que fazer novamente. Porque a chapa era descartável. Era muito difícil de fazer os registros das cores na máquina que a gente tinha. Então, uma capa poderia ser impressa num couchè 120, 160 gramas, laminado e encadernado. Tem todo um processo. A máquina só imprimia em ofício, A4 não existia naquela época. $O$ ofício é 21,2 por $32 \mathrm{~cm}$ o tamanho do papel, que é o tamanho das cartilhas que a gente produzia. (FERREIRA, 2019)

Em entrevista, Jânio explica que a diagramação das cartilhas era feita manualmente, "no olho", através da montagem dos textos e ilustrações, recortados e colados, em uma boneca, que era, então, apresentada ao coordenador específico da respectiva publicação para aprovação. Desse modo, o coordenador (sempre um membro da equipe da CPI-AC, embora hajam livros organizados pelos professores indígenas, eles não coordenavam os projetos) atuava como um diretor de arte, direcionando o projeto visual do livro, que era desenvolvido por Jânio. Nos créditos das publicações, tal função era creditada como "diagramação", e geralmente co-creditada com Jânio. Em outros casos, Jânio é creditado apenas pela impressão e/ou transcrição gráfica do material.

Eu fazia a boneca, uma boneca. "Jânio, tu vai produzir uma cartilha com 80 páginas". Com 80 páginas, com 100 páginas, na língua Yawanawa, por exemplo. Aí dava um texto. $\mathrm{O}$ texto era datilografado num tipo, numa tipografia adequada pra facilitar a leitura, e aí eu ia diagramando. Fazia tipo um molde, pra ficar tudo alinhado, né.

(...) Eu contratei minha irmã uma época - eles contrataram, eu pedi uma pessoa pra me ajudar porque eu não dava conta - a Altina. Aí a Altina trabalhava com desenho também, comigo, eu dizia "faz assim" e ela reproduzia tal e qual, pra eu pegar e montar a matriz, pra poder gravar as chapas. Era eu que fazia a diagramação, no olho. Não tinha computador pra você pegar e fazer na régua. Aí como a gente fazia aquilo corriqueiramente, pra mim era bem fácil. Eu fazia a boneca e mostrava pros coordenadores e era aprovado na hora. (FERREIRA, 2019)

Joaquim Luiz Tashkã Yawanawa ${ }^{8}$ é outra figura importante no desenvolvimento gráfico dos livros deste período. Seu nome consta pela primeira vez nos créditos de um material em 1991, e pela última vez em 2002 - ele foi responsável (sozinho ou em colaboração com outros membros da equipe) pela digitação de cerca de 40 livros no total. Tashkã, como é comumente chamado pelos colegas da CPI-AC, iniciou seu papel como "digitador de originais" em máquinas de escrever e foi responsável por operar os primeiros computadores da entidade, ainda no início da década de 1990. Ele e Jânio firmaram uma parceria, enquanto o segundo se responsabilizava pela configuração do texto, o primeiro tratava da diagramação das páginas.

8 Após sua experiência na CPI-AC Joaquim formou-se em cinema e passou a atuar como cineasta. Seu documentário Yawa, sobre a cultura e os rituais yawanawa, teve grande visibilidade ao concorrer na mostra do festival de cinema de Sundance. Atualmente, além de desenvolver projetos audiovisuais variados, Tashkã coordena a Associação Sociocultural Yawanawá, é ativista e integrante do comitê indígena de mudanças climáticas da ONU. 

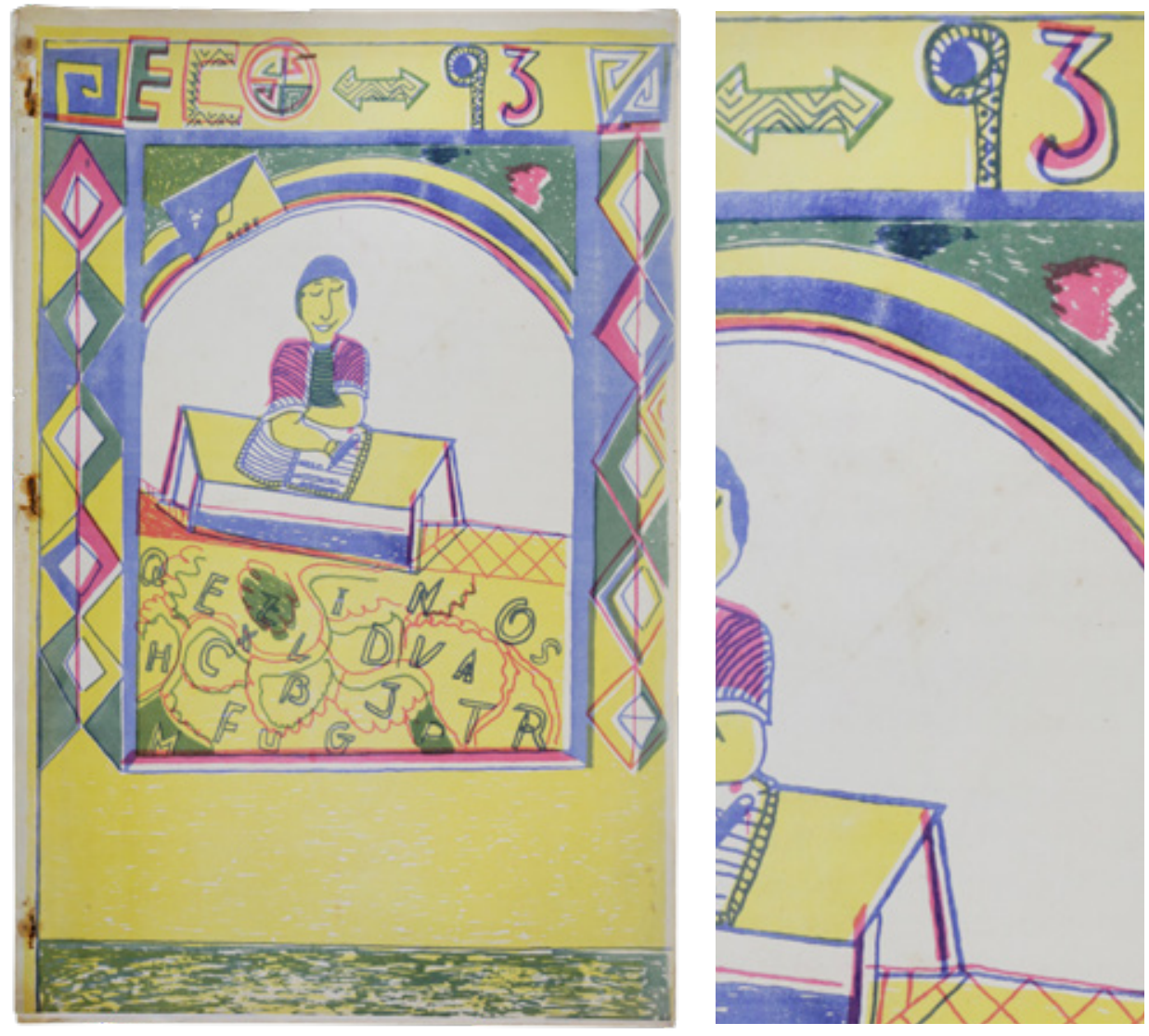

Figuras 65 e 66 :

Primeira capa de Aprendendo Português nas Escolas da Floresta (1993), com detalhe. Fonte: Pesquisa de campo, Paiva (2019).

Figura 67: Páginas do miolo de Aprendendo Português nas Escolas da Floresta (1993), Fonte: Pesquisa de campo, Paiva (2019).
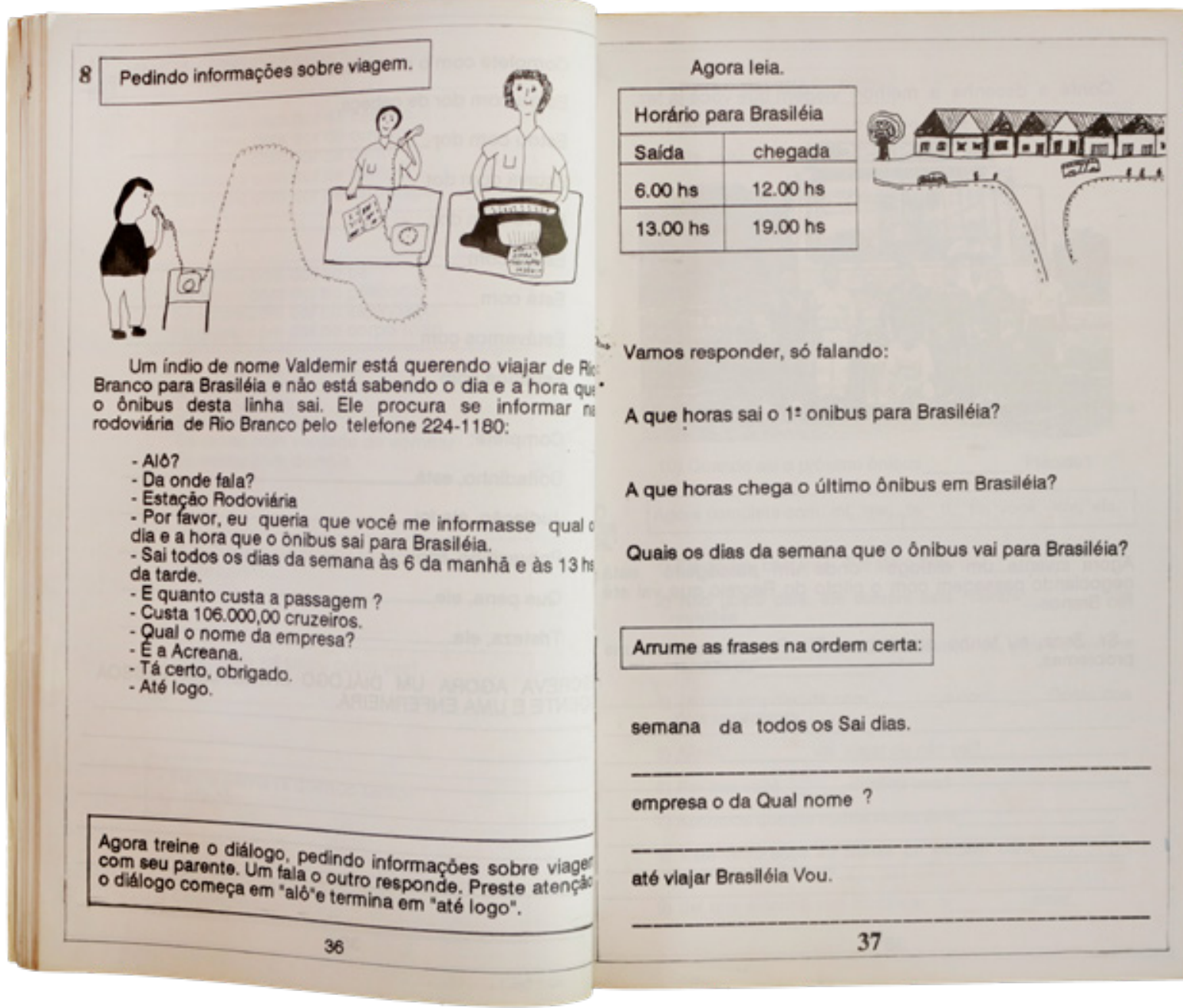

empresa o da Qual nome ?

até viajar Brasiléia Vou. 

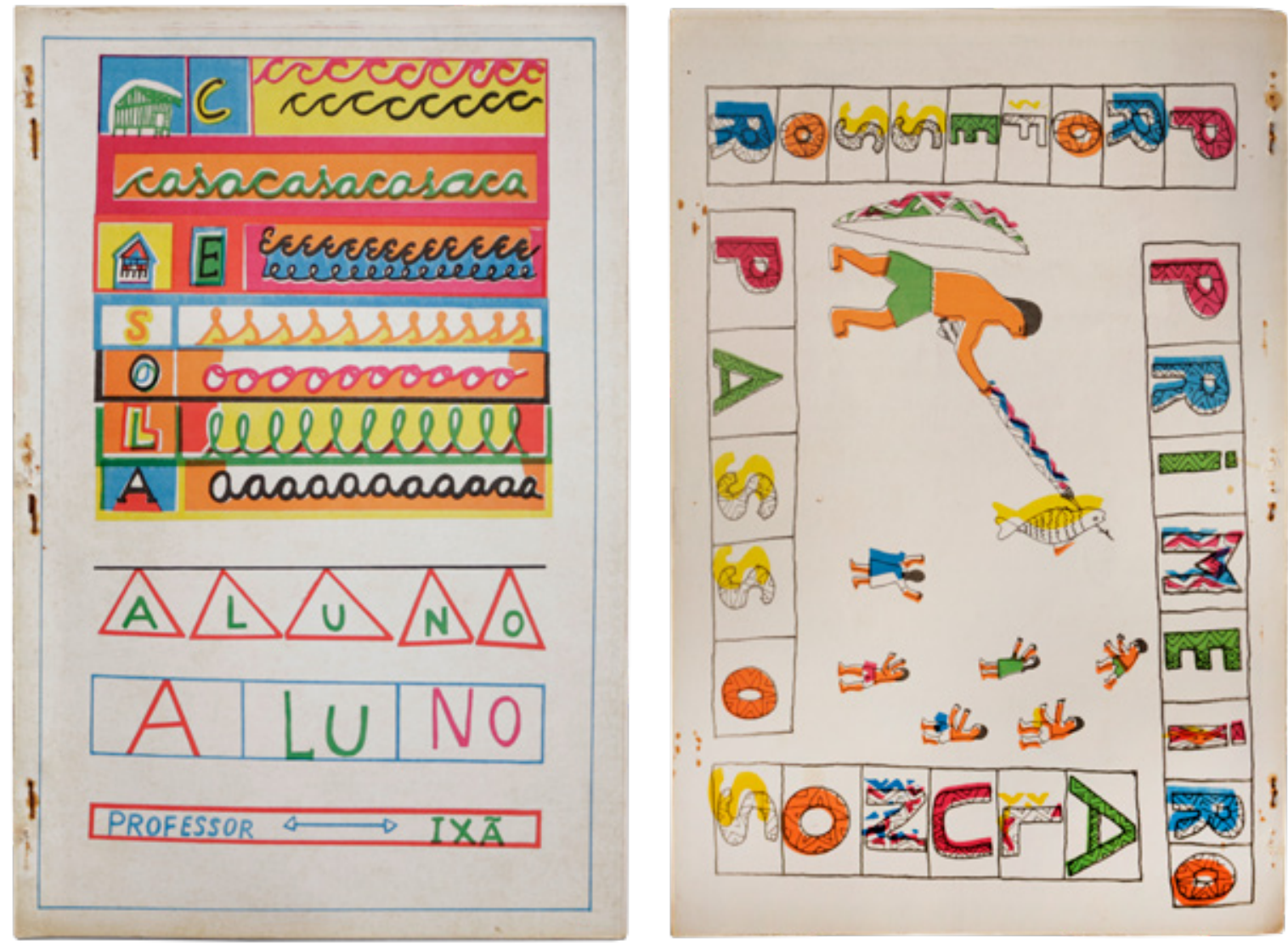

b) OProfessor mostra ficha por ficha, deixando que vários alunos procurem e descubram seus nomes.

c) Cada aluno recebe uma ficha qualquer com o nome de outra pessoa e entrega esta ficha ao dono.
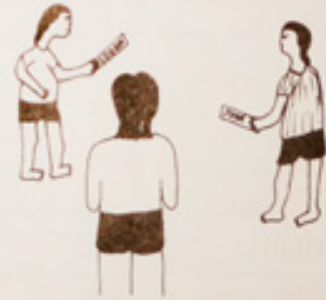

d) Cada aluno pega a ficha do seu nome reconhecendo-a no meio das outras.

e) Um só aluno distribui todas as fichas para os outros alunos.

Memorização dos nomes dos alunos.

Pedir que os alunos falem todos os nomes dos outros alunos e o professor vai escrevendo na lousa.
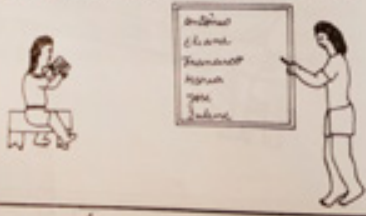

A partir dai várias atividades podem ser feitas:

a) Marcar a letra inicial $\left(1^{\circ}\right.$ letra)

b) Ver quantos nomes começam com a letra A, com a letra $\mathrm{B}$, com a letra $\mathrm{C}$ e assim por diante.

c) Contar quantas letras tem cada nome $\mathrm{e}$ comparar, perguntado quais os nomes que têm mais letras? Quais os nomes que têm menos letras?

Estas atividades poderão ser feitas também em folhas de papel, que o professor aprontará antes da aula.

Exemplo:

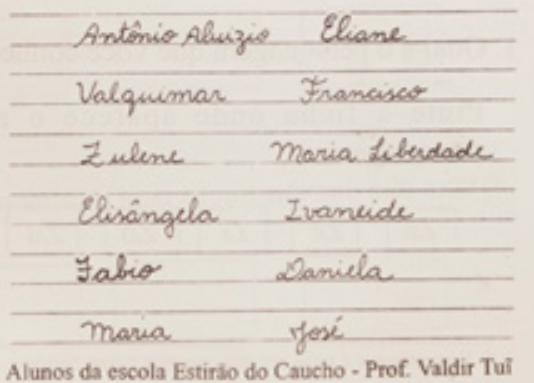

Cada professor escreverá o nome dos seus alunos.

Figuras 68, 69 e 70: Primeira capa, quarta capa e páginas do miolo do Caderno de Alfabetização (1995). Fonte: Pesquisa de campo, Paiva (2019). 
Naquela época da CPI era tudo muito manual, nós tínhamos uma offset e tinha que recortar os desenhos, fazer várias colagens, umas dez colagens para montar um desenho. E para fazer colorido era mais ainda e montar os textos era a mesma coisa (...). Nós usávamos programas muito antigos, para escolher as letras, maior, menor, curvada. (TASHKÃ YAWANAWA, 2019).

Em 1993 pra 1994 foi quando chegou o primeiro computador, salvo engano. Que era apenas pra fazer texto. Fazer texto em coluna, um programa, e tinha um programa com o nome de banner que era usado pra fazer o texto. Aí já deu uma melhorada pra mim porque até então, os títulos eu fazia na mão mesmo. Era desenhada a letra. Não tinha computador.

(...) Eu diagramava e o Joaquim que operava no computador, eu sentava do lado dele e a gente fazia. Eu pedia pra ele fazer o texto, ele fazia, aí eu dizia: "diminui um pouquinho a fonte, aumenta um pouquinho pra preencher a página”. (FERREIRA, 2019)

Segundo Tashkã e Jânio, Renato Antônio Gavazzi ${ }^{9}$ era o membro da CPI-AC que mais atuava no direcionamento e coordenação dos projetos visuais dos livros. Com as muitas conversas realizadas com os membros, atuais e antigos, da entidade, fica claro que Renato é percebido enquanto uma pessoa com uma "sensibilidade" visual grande, uma certa facilidade estilística para o desenvolvimento dos projetos. Segundo o próprio Renato, esse papel de consultoria era exercido por ele de modo orgânico, sem um método bem definido.

Sim, eu dava orientações, as pessoas pediam para mim, orientações e tal, mas eu sou responsável pela organização dos materiais que eu realmente organizei. Os outros eu dava alguns toques, mas nem sempre as pessoas seguiam. Também não é que a gente ficava só fazendo isso, a gente trabalhava no curso, ia paras Terras Indígenas. Não era uma coisa que você tem um tempo específico para isso, as coisas tinham um ritmo muito próprio, com muitas atividades, mas enfim, era esse o ritmo da instituição. (GAVAZZI, 2019)

De fato, Geografia Indígena, de 1992, o primeiro livro organizado por Gavazzi (e também o primeiro livro de geografia, a primeira disciplina fora matemática e português a ser explorada em publicação), se destaca visualmente pela riqueza de ilustrações coloridas, que geralmente ocupam toda a página. $\mathrm{O}$ contraponto dessas páginas ricamente desenhadas é feito com margens e espaços de respiro generosos nas páginas de texto, que incluem poesias, textos técnicos, relatos e exercícios. As ilustrações também variam entre interpretações mais artísticas e mapas técnicos ilustrados. Este também é um dos primeiros materiais da coleção em que a página de créditos é ilustrada e cuidadosamente diagramada, com todas as funções devidamente

9 Conforme mencionado anteriormente, Renato é geólogo e entrou na equipe da CPI-AC em 1990, para coordenar a disciplina de geografia nos cursos de formação de professores. Com o passar do tempo ele começou a editar outros materiais, especialmente os de manejo, decorrentes dos cursos de agentes agroflorestais. Apesar destas serem suas especialidades, ele era comumente consultado pelos coordenadores de outras disciplinas no que dizia respeito à configuração dos materiais impressos. 

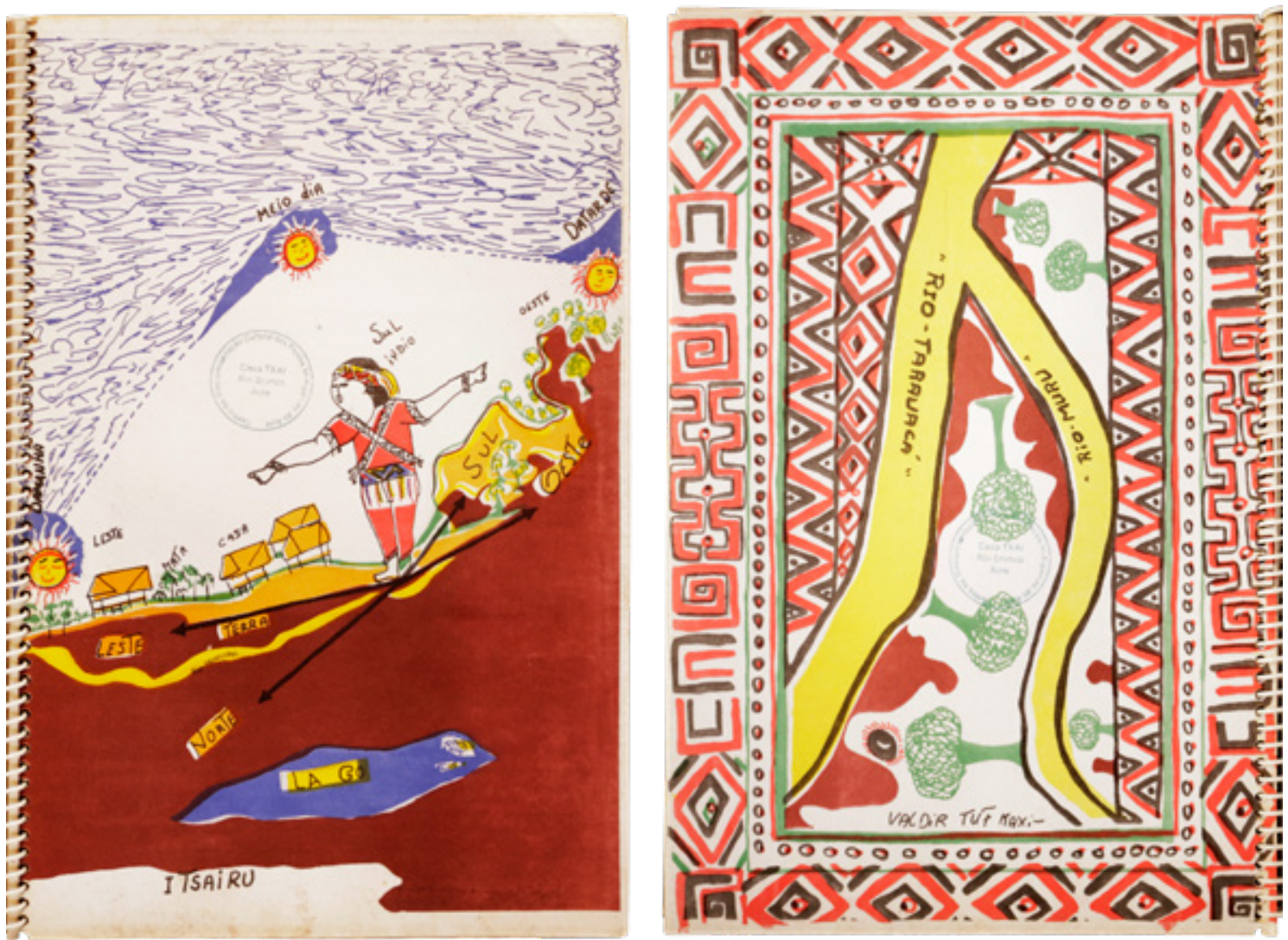

Figuras 71 e 72: Primeira e quarta capas da Cartilha de Geografia - Geografia Indígena (1992). Fonte: Pesquisa de campo, Paiva (2019). listadas e creditadas - o que, até então, não era tão comum nos materiais produzidos. Em 1994 mais cinco materiais de geografia foram produzidos, Geografia Apurinã, Geografia Jaminawa, Geografia Katukina, Geografia Kaxinawá (reeditado em 2001 como Geografia Huni Kuĩ) e Geografia Yawanawa, todos seguindo o mesmo padrão de qualidade gráfica imposto pelo primeiro, com destaque para aplicações tipográficas em display com algumas estilizações interessantes, que não aparecem com frequência em outros materiais.

Renato também é responsável pela organização do Atlas Geográfico Indígena, lançado em 1996 e reeditado em 1998, um dos livros mais interessantes da Coleção. Trata-se de um conjunto de mapas, abundantemente ilustrados, que abordam questões geográficas, políticas e sociais das etnias Kaxinawá, Manchineri, Katukina, Jaminawa, Apurinã, Shawanawa e Ashaninka.

Não havia uma ficha de créditos padrão para as publicações, o que ocasionava algumas questões no que diz respeito aos tópicos geralmente registrados. Embora algumas publicações possuam um certo padrão, este se manifesta apenas em parte dos livros, e muitas vezes não conta com algumas informações - tais como o ano de publicação, conforme mencionado anteriormente.

Desse modo, e especialmente nas publicações até a segunda metade da década de 1990, as informações presentes nas folhas de créditos são inconstantes, assim como o próprio método de formulação desses créditos. Por exemplo, alguns livros contam com textos assinados individualmente, mas não apresentam uma lista de autores, enquanto em outros tem-se o contrário (há uma lista de autores, mas não se sabe quem foi responsável por cada texto). Percebe-se que, geralmente, os livros compostos majoritariamente por exercícios, tais como as cartilhas de alfabetização, pré-alfabetização e de matemática, fazem uso da lista de autores em geral, não havendo créditos específicos para cada exercício, já que os mesmos eram produzidos em conjunto nos momentos de formação. Já nos materiais que combinam textos e exercícios, como costuma ser o caso das cartilhas de 


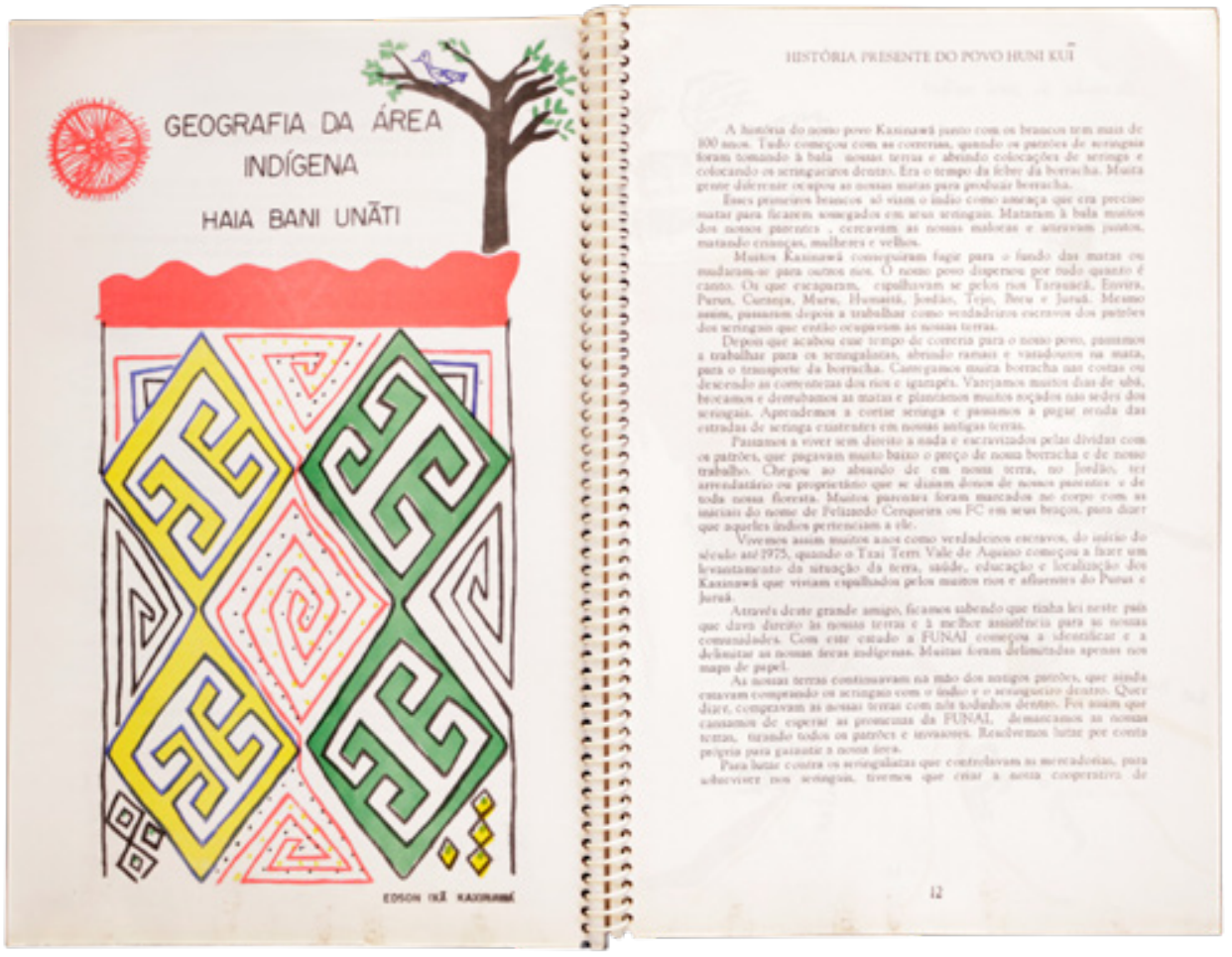

Figuras 73 e 74 :

Páginas do miolo da Cartilha de Geografia

- Geografia Indígena (1992). Fonte: Pesquisa de campo, Paiva (2019).

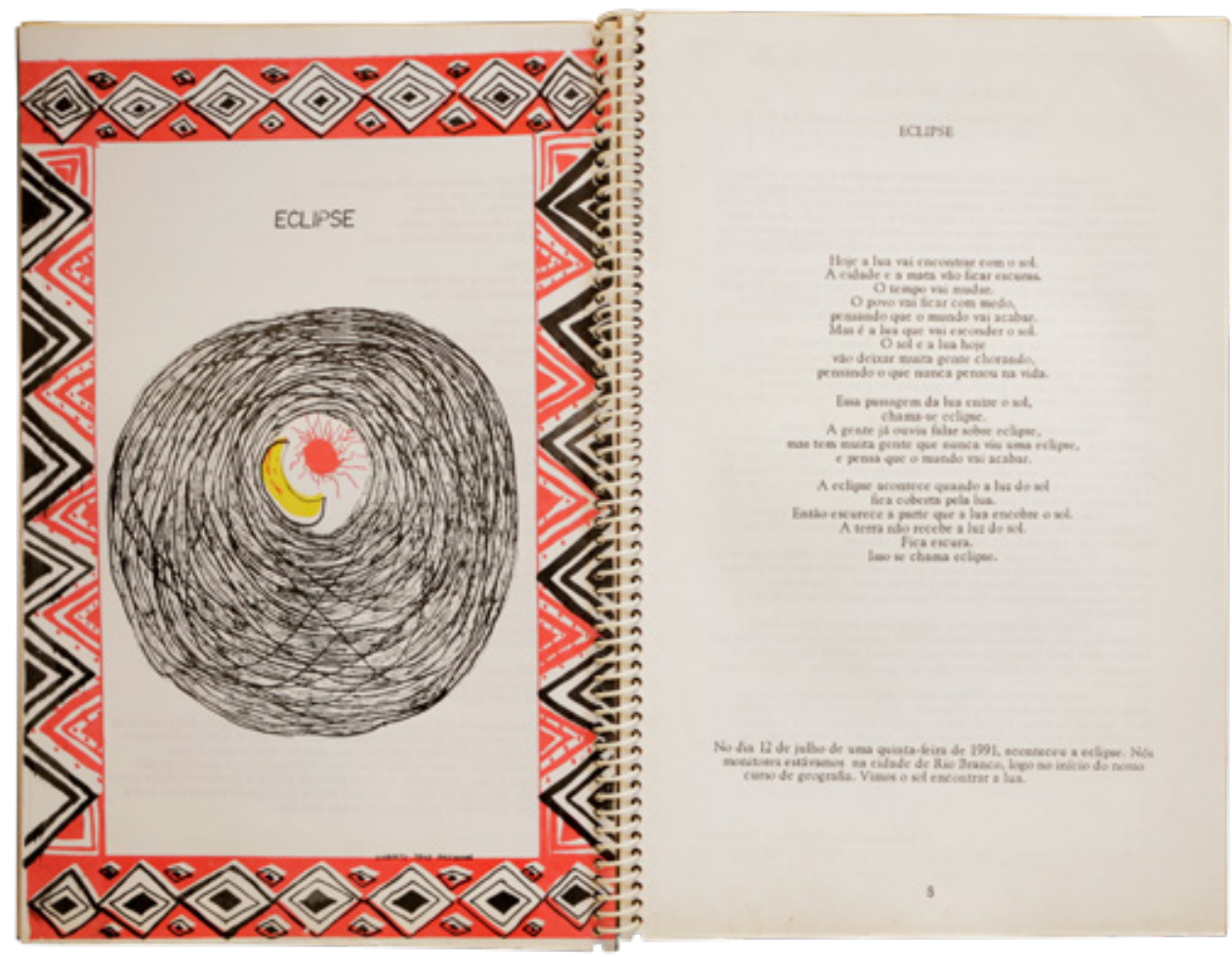

geografia, história, e pós-alfabetização, os textos utilizados como aporte para os exercícios vem individualmente assinados (ainda que às vezes a assinatura seja "grupo de monitores"). Já nos livros de narrativas, é comum haver créditos mais completos que incluem também narradores.

As ilustrações, da mesma forma, são em alguns momentos assinadas, em outros não, e também é comum encontrar listas de "autores e ilustradores" em materiais, de forma que nem os textos nem as ilustrações são especificamente creditadas.

Acredita-se que estas questões se devem aos métodos coletivos de produção de textos e ilustrações nos momentos de formação, que, provavelmente, dificultavam o registro de autores específicos de cada texto e desenho $-76.5 \%$ do total de livros são de autoria coletiva. 

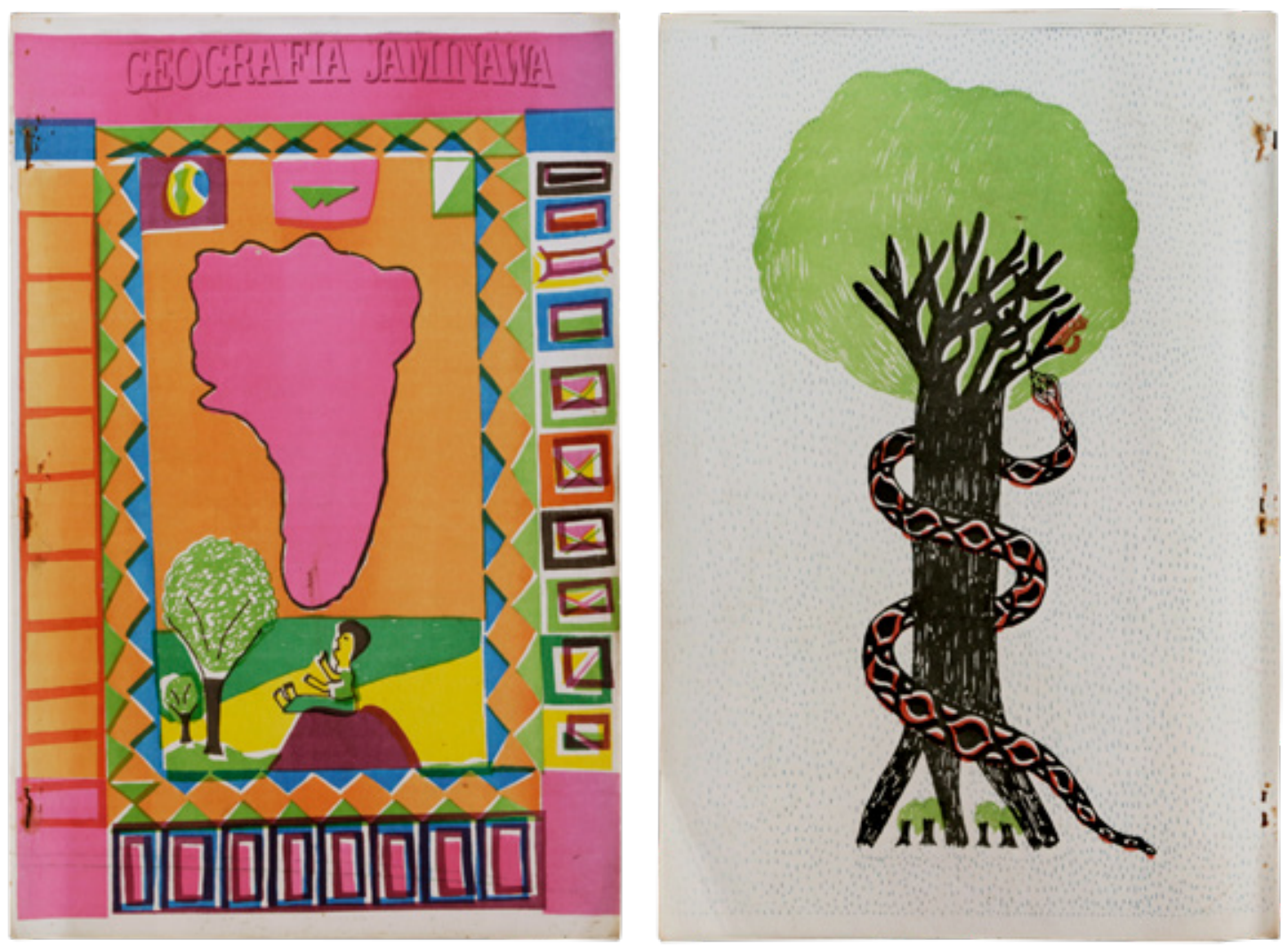

Figuras 75 e 76: Primeira e quarta capas de Geografia Jaminawa (1994). Fonte: Pesquisa de campo, Paiva (2019).
Outra questão que deve ser levada em conta é o caráter coletivo de muitos dos conteúdos produzidos. Nesse caso, refere-se tanto a exercícios desenvolvidos em conjunto em sala de aula, quanto a mitos e histórias que pertencem a toda uma etnia ou comunidade, não possuindo um "autor" específico, conforme os modelos ocidentais tradicionalmente utilizados para definir a autoria de determinada obra.

Um outro ponto é a própria prática editorial que foi sendo adquirida pela equipe da CPI-AC. Tanto é que, com o passar dos anos, os créditos passam a ficar mais completos, mais padronizados e mais específicos, passando a incluir narradores, colaboradores, revisores etc, funções que não eram encontradas anteriormente. A maioria esmagadora dos impressos também não conta com ficha catalográfica, sendo Antologia da Floresta, de 1997, editado pela Multiletra, a única exceção até 2001, quando Hinkaklu - MTA, uma coletânea de mitos manchineri, é lançado. Depois de Hinkaklu, a presença da ficha catalográfica ainda é inconstante (alguns livros possuem, outros não) até 2007, a partir de quando todos os livros passam a apresentá-la.

Considerando o total de livros da Coleção, apenas cerca de $14 \%$ possui ficha catalográfica. Já com relação ao tipo de crédito, $81,2 \%$ apresenta lista de autores, e apenas em $22,4 \%$ dos livros cada texto está respectivamente assinado. Os ilustradores são listados especificamente em $21,2 \%$ dos livros - na maior parte dos casos, assume-se que os autores também foram ilustradores do material, informação que geralmente encontra-se na apresentação ou prefácio do material. Em apenas 3,5\% dos títulos as ilustrações são assinadas sistematicamente (é importante ter em mente nesse momento que $93 \%$ dos livros da Coleção são ilustrados), ou seja, fora os casos em que o nome do ilustrador está presente no próprio desenho (o que ocorre com certa frequência, porém de maneira esparsa).

De todo modo, é uma questão sensível entender o motivo pelo qual a CPI-AC optou por não inserir os nomes dos autores nas capas dos livros produzidos, optando por utilizar sempre paginas internas de créditos. Essa foi uma pergunta feita algumas vezes durante as entrevistas, mas a resposta era 


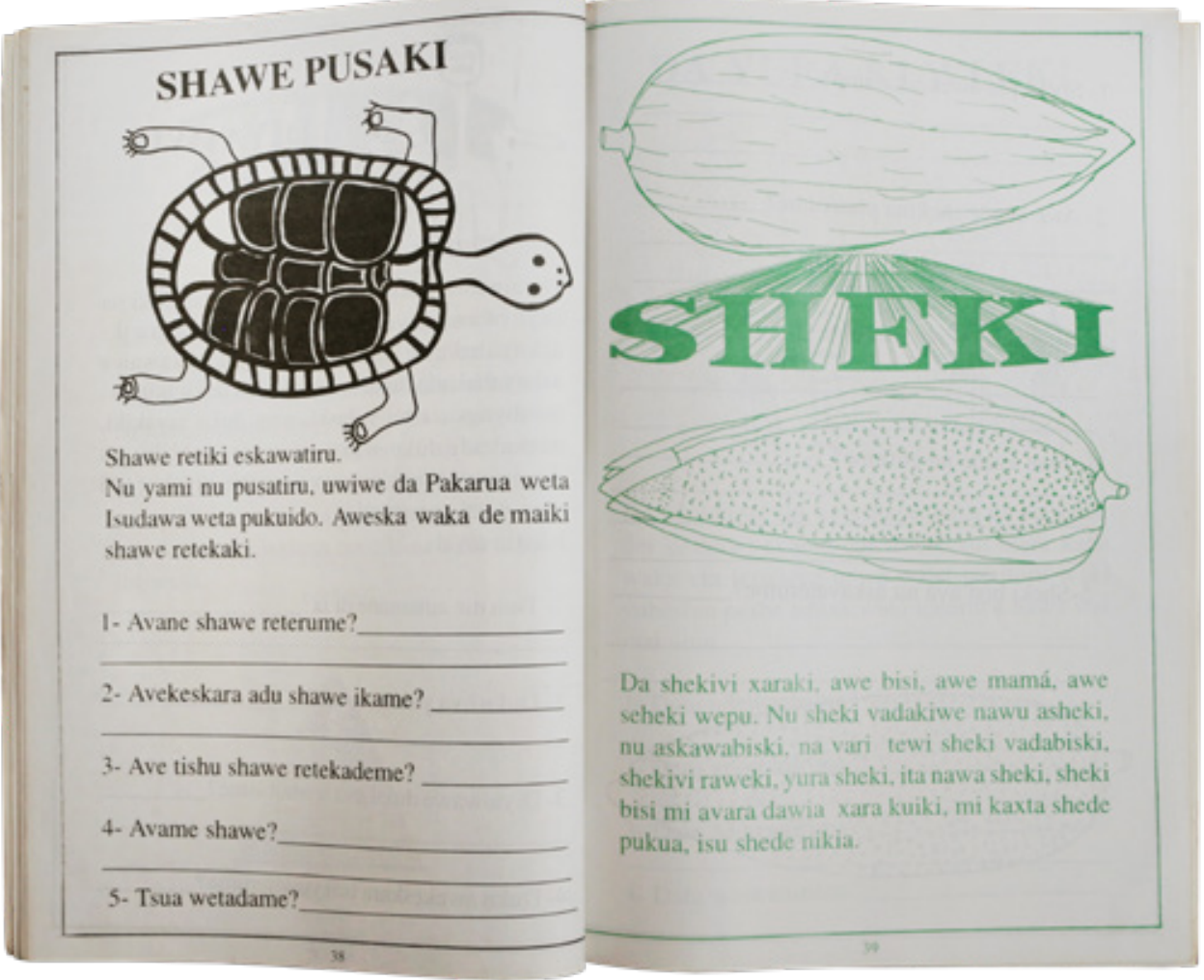

Figuras 77 e 78 :

Páginas do miolo de Geografia Jaminawa (1994). Fonte: Pesquisa de campo, Paiva (2019).
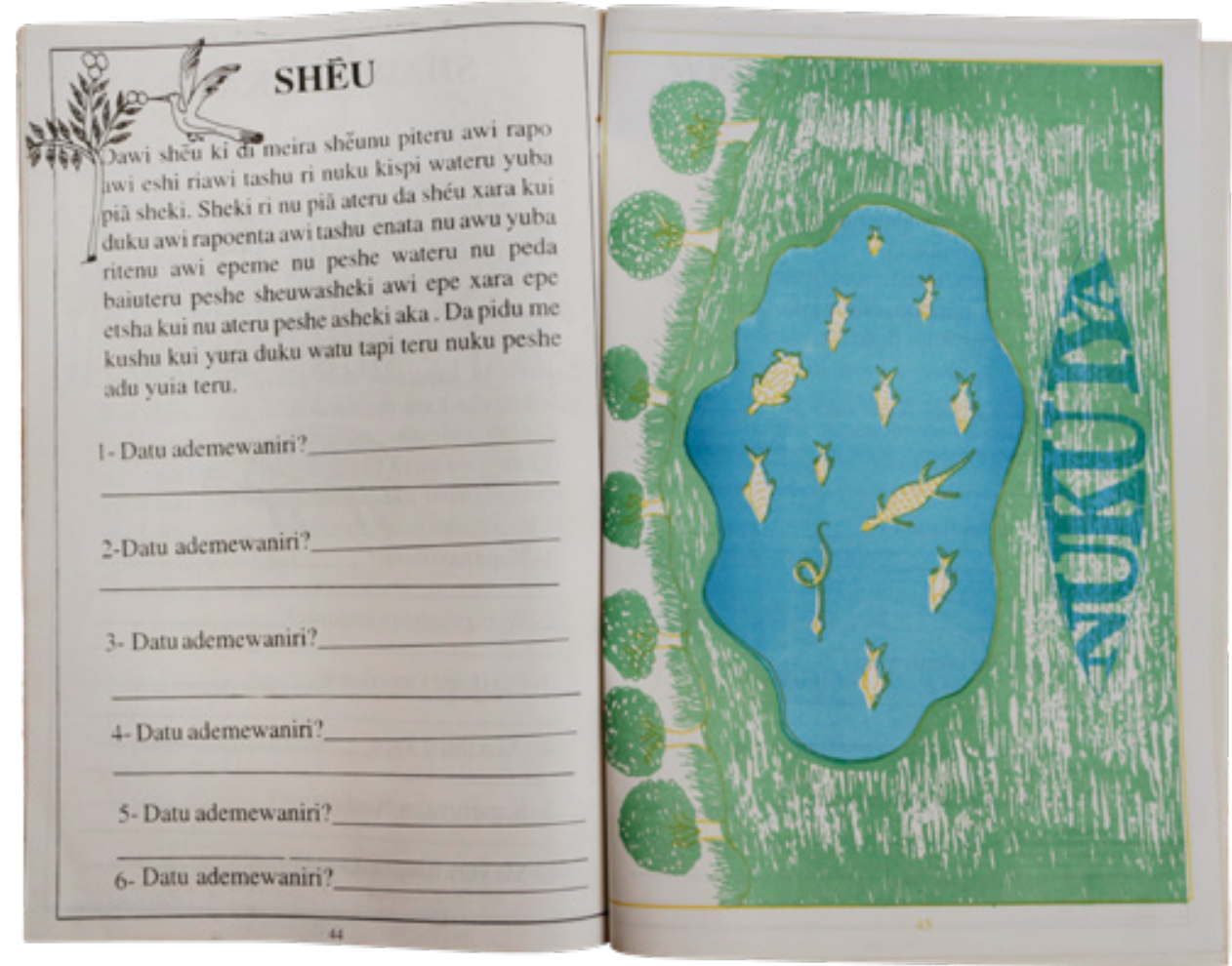

sempre relacionada a como este era um direcionamento padrão da entidade, e não foi possível definir os motivos por trás de tal direcionamento. Nas falas dos membros da equipe, ao tratar dos primeiros anos de atuação, especialmente no projeto de educação, percebe-se que havia uma preocupação em estabelecer uma "marca" da CPI-AC nos trabalhos publicados, no sentido de firmar o trabalho desenvolvido e os frutos publicados em forma de publicações, processo significativo para estabelecer o projeto como sério e importante. Em se pensar que o projeto de educação tem início antes mesmo da educação indígena ser garantida enquanto direito constitucional, a lógica faz sentido. 

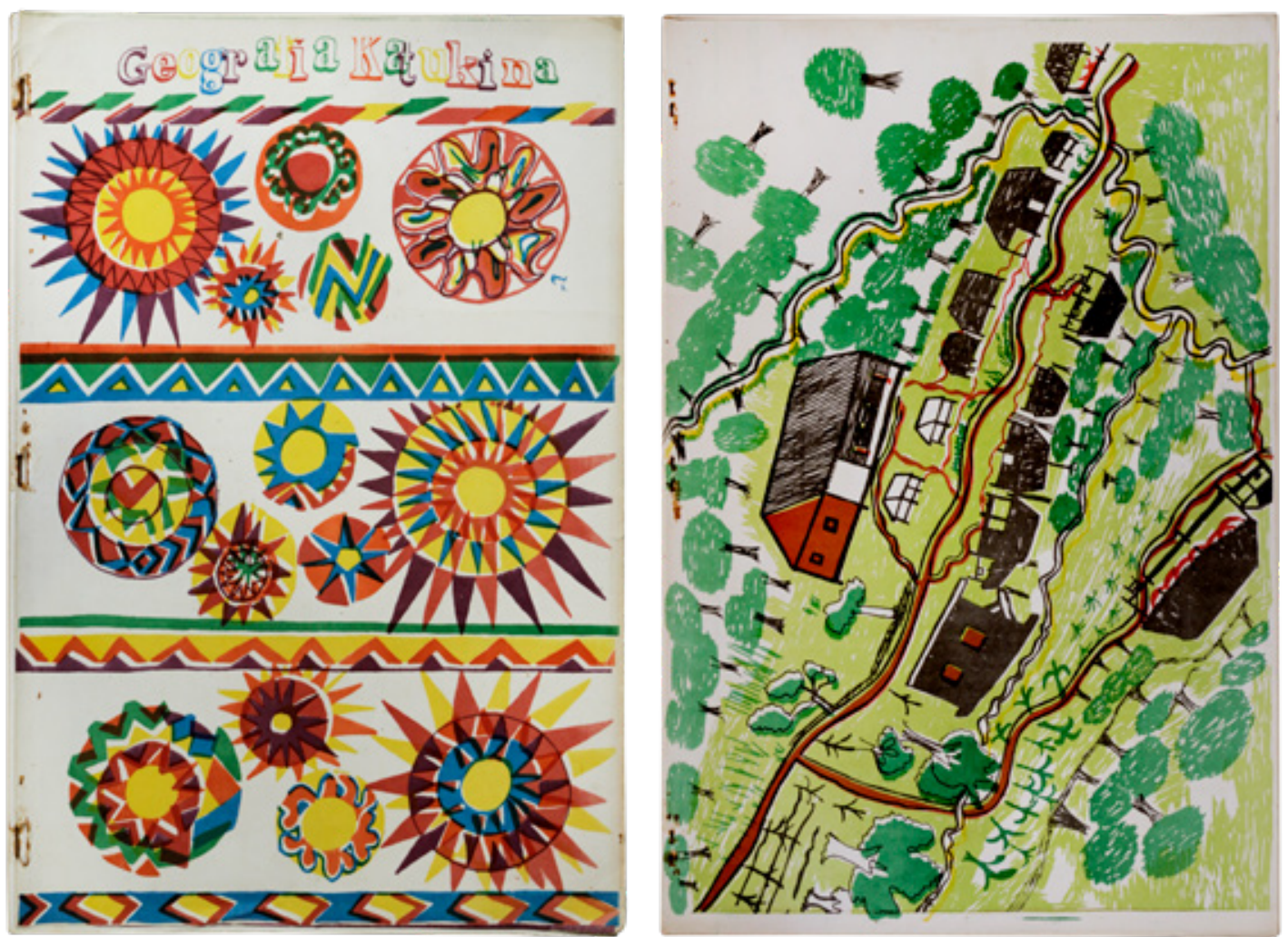

Figuras 79 e 80 : Primeira e quarta capas de Geografia Katukina (1994). Fonte: Pesquisa de campo, Paiva (2019).
Ressalta-se que a organização, padronização e detalhamento dos créditos desenvolveu-se paulatinamente com o passar dos anos, e as questões relativas a créditos mais genéricos estão mais associadas aos primeiros livros produzidos. Com a criação da OPIAC em 2001, todos os livros produzidos por grupos de professores passaram a contar com a logo da Organização na capa, juntamente à logo da CPI-AC.

Cabe mencionar que, com o decorrer dos anos, indígenas passaram a aparecer em cada vez mais funções nas páginas de créditos dos livros da Coleção: se nas primeiras publicações, no início da década de 1980, seus nomes apareciam como autores e ilustradores, até meados da década de 1990 já constam indígenas como datilógrafos, organizadores, tradutores, editores, revisores e, inclusive, diagramador, no caso específico de Tashkã.

Todos os entrevistados que participaram dos processos de configuração gráfica e editorial dos livros nesse período ressaltam as grandes dificuldades sofridas devido à complexidade dos processos, extremamente trabalhosos e manuais. Ainda assim, os materiais publicados possuem riqueza de detalhes e ilustrações abundantes em cores diversas, inclusive com tonalidades produzidas especialmente por Jânio (FERREIRA, 2019). Alguns dos originais de ilustrações utilizadas nos miolos e capas dos livros produzidos neste período encontrados preservados em acervo no CDPI permitem a constatação do nível de detalhe e fidelidade com o qual as composições eram reproduzidas, o que ganha uma dimensão ainda maior ao considerar-se a dificuldade para a impressão. Cada cor demandava a gravação de uma chapa específica, e uma etapa de impressão. Ou seja, um desenho com 5 cores demanda a gravação de 5 matrizes e cada folha de papel impresso terá que passar pela impressora 5 vezes.

Porque quando você vai imprimir na offsset, por exemplo, um negócio desse aqui com cinco cores. Tu passa uma vez, tu tem que imprimir ele cinco vezes, se forem 5 cores. Como nossa região é quente e úmida, o papel absorve. A máquina trabalha molhando a chapa. Esse 

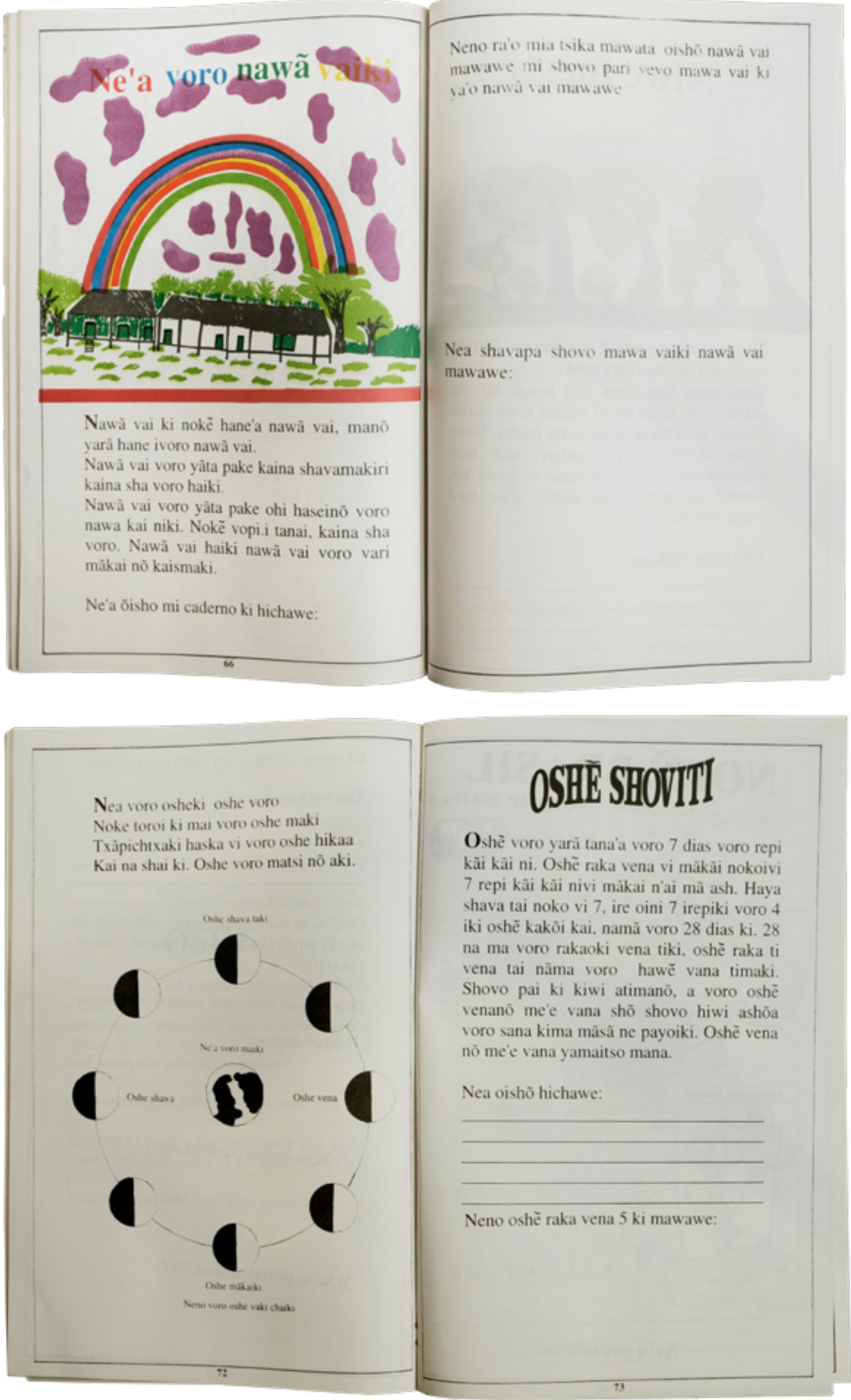

Figuras 81 e 82: Páginas do miolo de Geografia Katukina (1994). Fonte: Pesquisa de campo, Paiva (2019). 

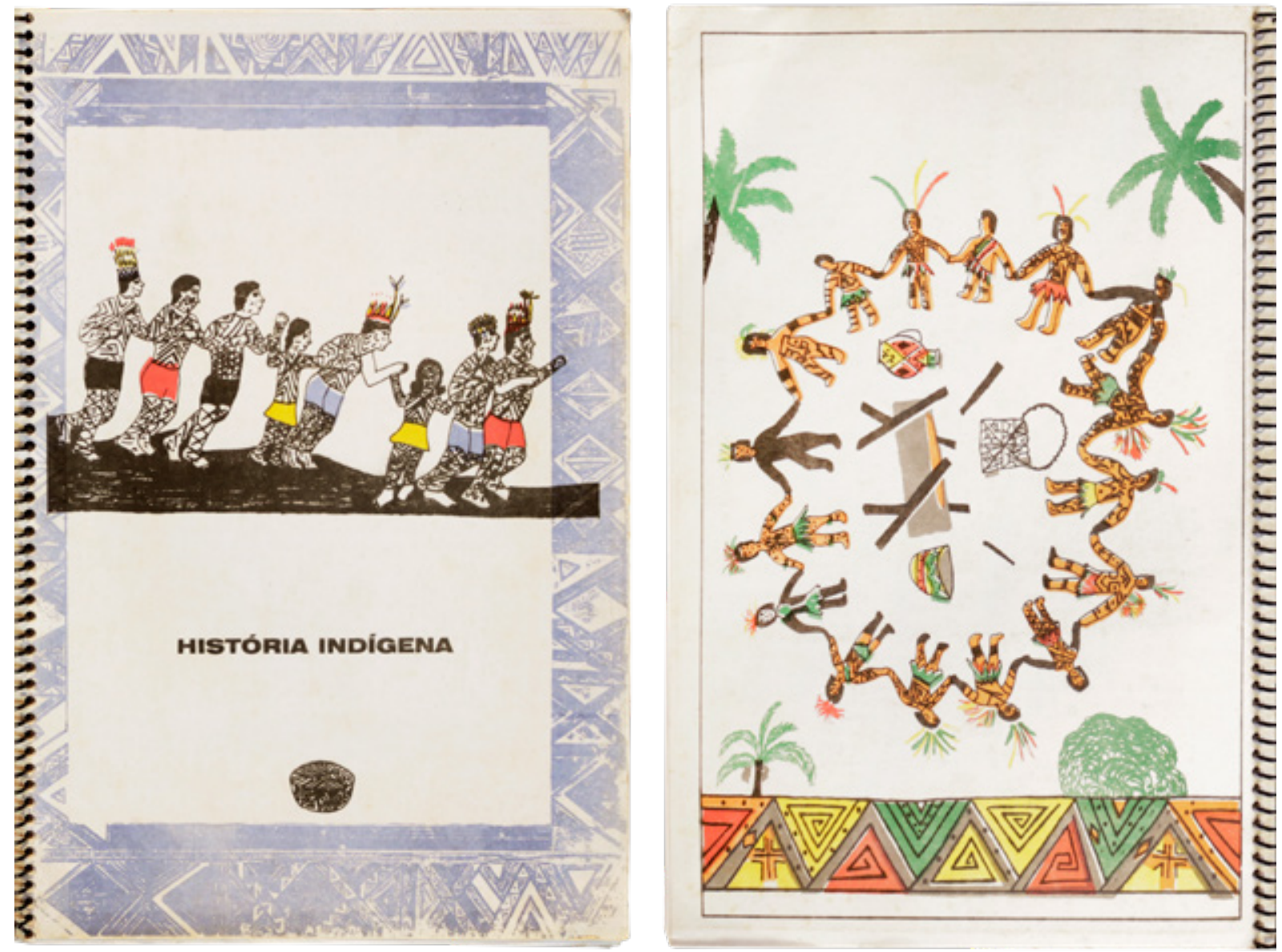

Figuras 83 e 84:

Primeira e quarta capas de História Indígena (1996). Fonte: Pesquisa de campo, Paiva (2019). molhado da chapa vai pra banqueta, que vai pro papel. Ele não molha o papel, mas tem a umidade da banqueta, que recebe da chapa. E essa umidade, por exemplo, eu começava a imprimir de manhã. Quando chegava de tarde, já tinha uma diferença medonha. Porque o papel encolhia, aí ele não registrava. Por exemplo, uma capa com 5 cores. Eu vou imprimir ela cinco vezes, então eu tenho que gravar cinco chapas, e ela vai passar cinco vezes. Eu passo amarelo, aí termino mil folhas. Limpo a máquina, e o papel fica lá. Aí quando eu termino eu pego ele de novo, boto na máquina. Aí vou fazer um encaixe, pra ela encaixar. É muito difícil você fazer pra bater um em cima do outro, como hoje a gente faz. Hoje a gente faz, só que na chapa long run, ela não te dá uma em cima da outra, era meio que no olho. Então tu tinha que pegar e fazer os acertos na mão mesmo. (FERREIRA, 2019)

A dificuldade em manter o registro, ou seja, o alinhamento meticuloso das chapas para que as cores sejam impressas nas áreas planejadas, causa sobreposições e deslocamentos que findam tornando-se parte das composições. Curiosamente, o resultado é, muitas vezes, esteticamente interessante, apesar de não intencionado. Pode-se, inclusive, traçar uma interessante relação entre a sobreposição de cores e a sobreposição de planos presente em muitas das ilustrações indígenas, especialmente no caso dos ilustradores kaxinawá.

Em 1995, no Caderno de Alfabetização, a Gráfica Kene Hiwe aparece pela primeira vez creditada na impressão do material (até então utilizava-se "Setor gráfico da Comissão Pró-índio"). Seu nome (às vezes como gráfica, às vezes como editora $)^{10}$ aparece em todos os livros seguintes que possuem

10 Ver a figura 160, na página 155. 


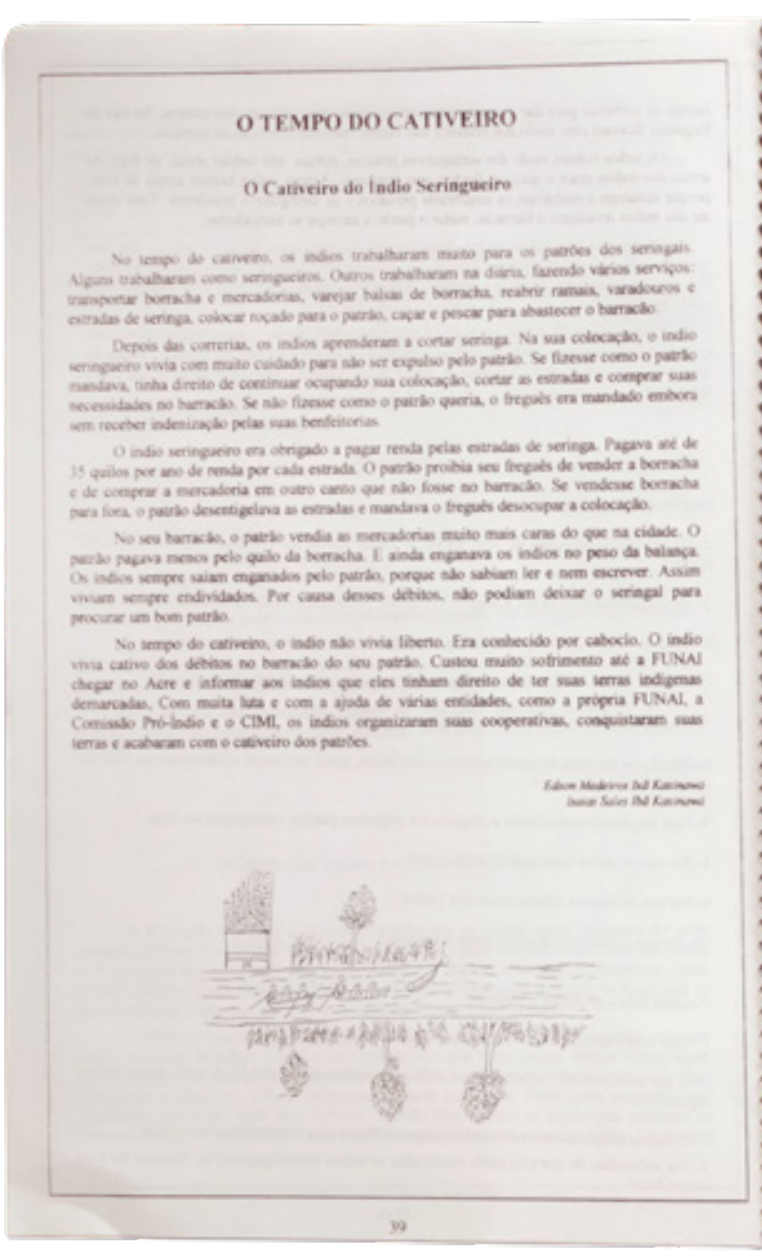

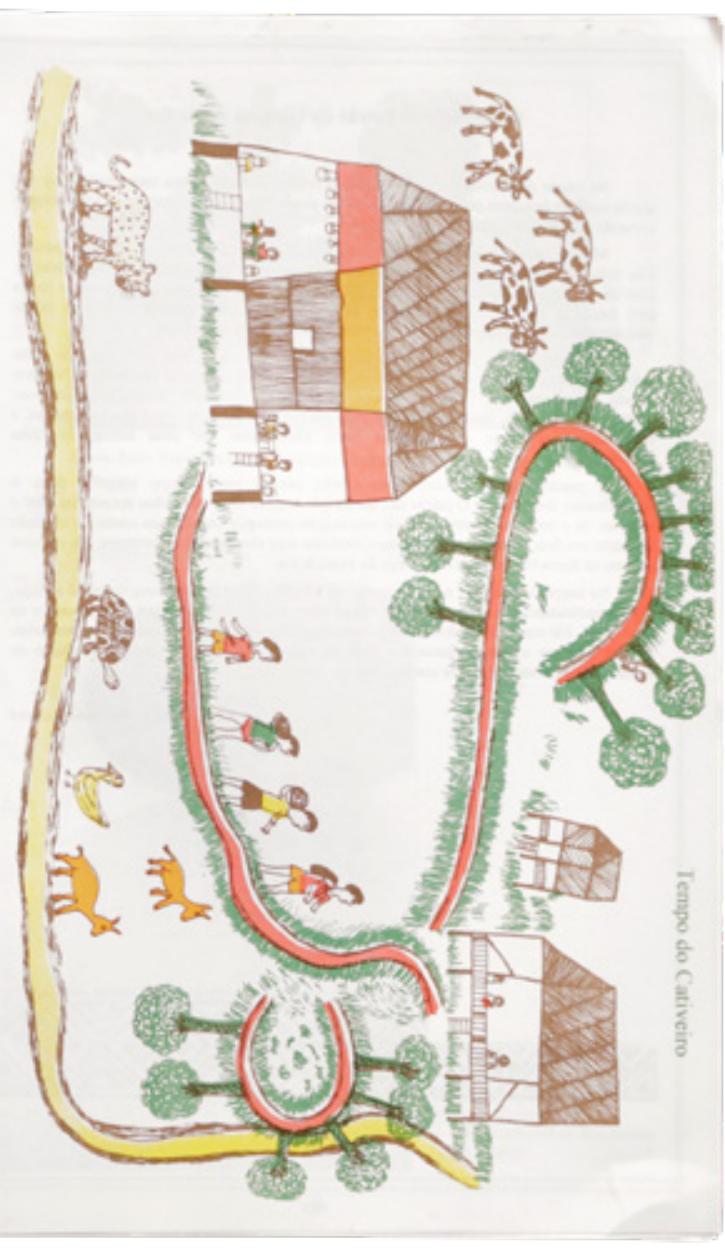

crédito de impressão, até o ano de 1998, mais especificamente na primeira edição de Chegou o Tempo de Plantar as Frutas, onde o crédito de impressão passa a ser da Gráfica Poronga, a gráfica do CTA, até o início dos anos 2000.

Apesar da diversidade de temas e projetos, o comportamento gráfico dos livros mantém um certo padrão que ainda é decorrente dos primeiros livros na década de 1980. Agora com mais variedade tipográfica, especialmente a partir de 1994, as cartilhas ainda apresentam exercícios com ilustrações alternadas. $\mathrm{O}$ miolo dos livros de leitura, via de regra, alternam páginas com apenas ilustrações e páginas de texto. As fontes costumam apresentar um corpo levemente maior nas cartilhas e menor nos outros livros. A maior parte dos livros é em formato ofício e orientação retrato, com algumas poucas exceções e experiências em orientação paisagem.

As ilustrações são o aspecto visual mais marcante dos livros produzidos neste período. A originalidade dos traços e das representações visuais somadas às características técnicas específicas da forma de impressão, com áreas chapadas de cores vibrantes que se sobrepõem, a expressividade das linhas e a liberdade compositiva dos professores indígenas atraem o olhar do leitor e possuem tanta ênfase quanto o conteúdo verbal escrito.

A etapa de transição das matrizes recortadas e coladas com ilustrações reproduzidas manualmente com canetas nanquim, para o digital, com layouts produzidos diretamente no computador e a necessidade de digitalização das imagens, geraram alguns problemas técnicos de reprodução, particularmente no que diz respeito às imagens. Por exemplo, na segunda edição de Aprendendo Português nas Escolas da Floresta, de 1997, as ilustrações são completamente pixeladas, o que provavelmente deriva de problemas com a resolução das imagens e do manuseio de softwares para colori-las digitalmente (TASHKÃ YAWANAWA, 2019). 

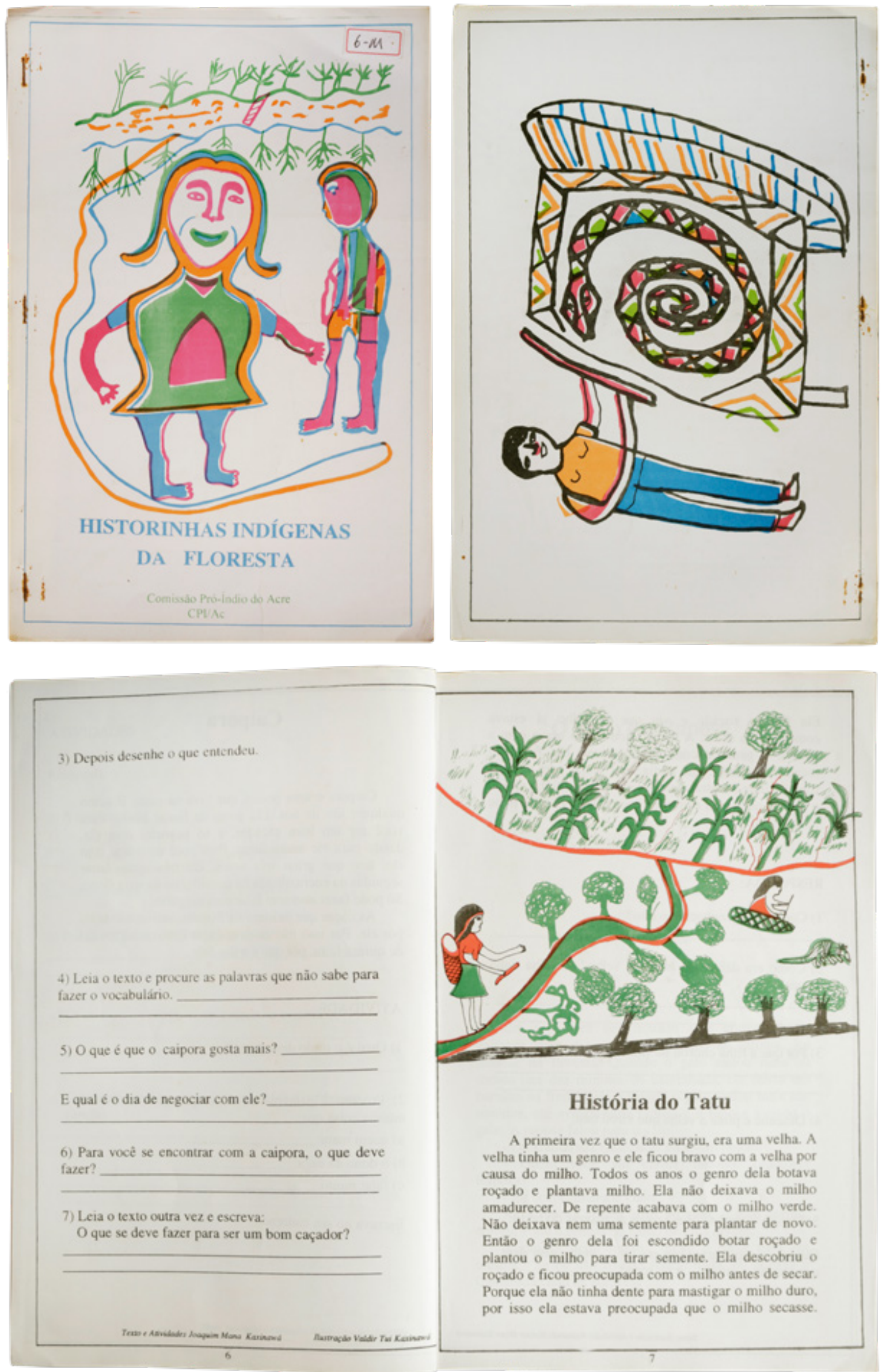

Figuras 87, 88 e 89: Primeira capa, quarta capa e páginas do miolo de Historinhas Indígenas da Floresta (1995). Fonte: Pesquisa de campo, Paiva (2019). 

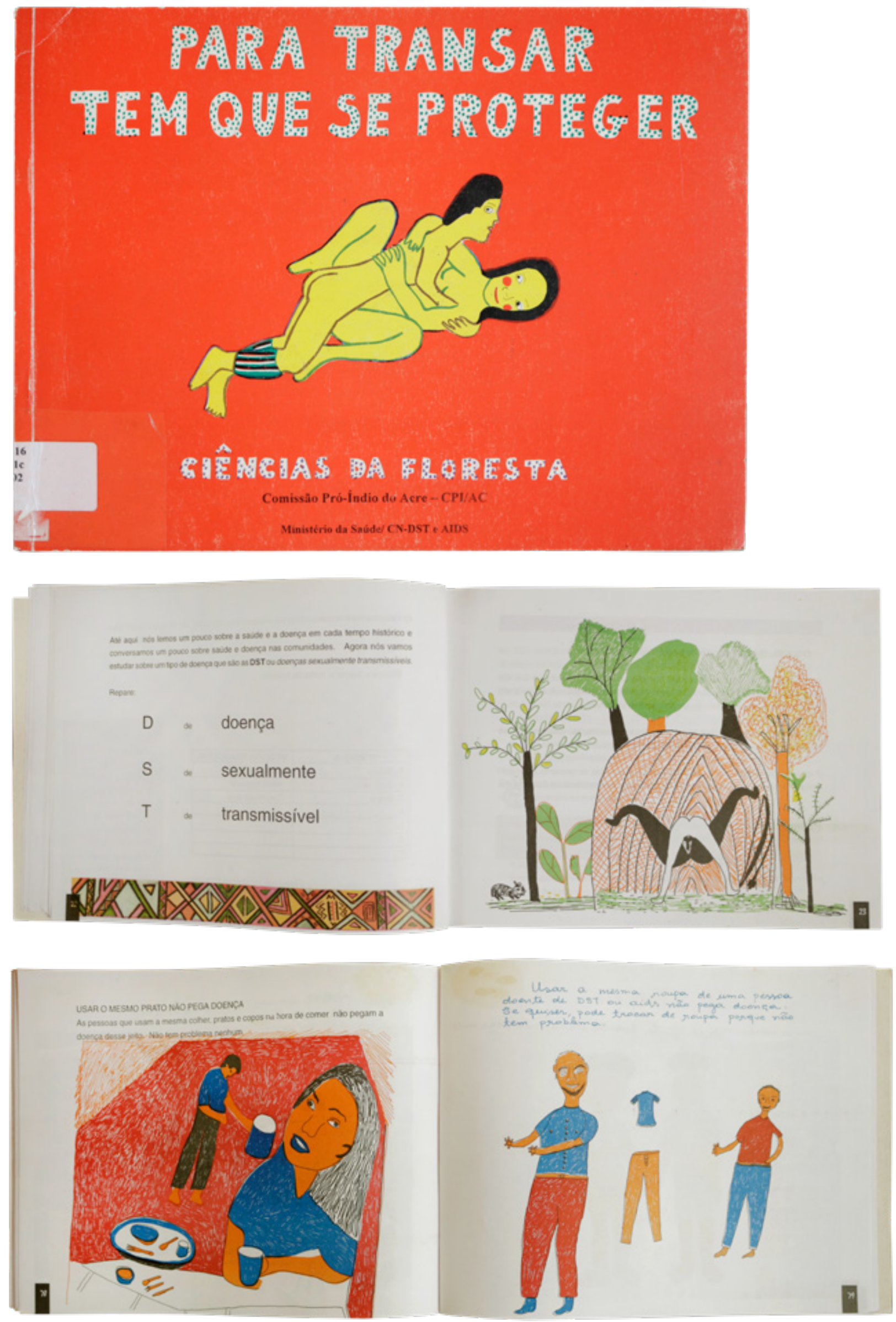

Figuras 90, 91 e 92: Primeira capa e páginas do miolo de Para Transar Tem que se Proteger - Ciências da Floresa (1999). Fonte: Pesquisa de campo, Paiva (2019). 

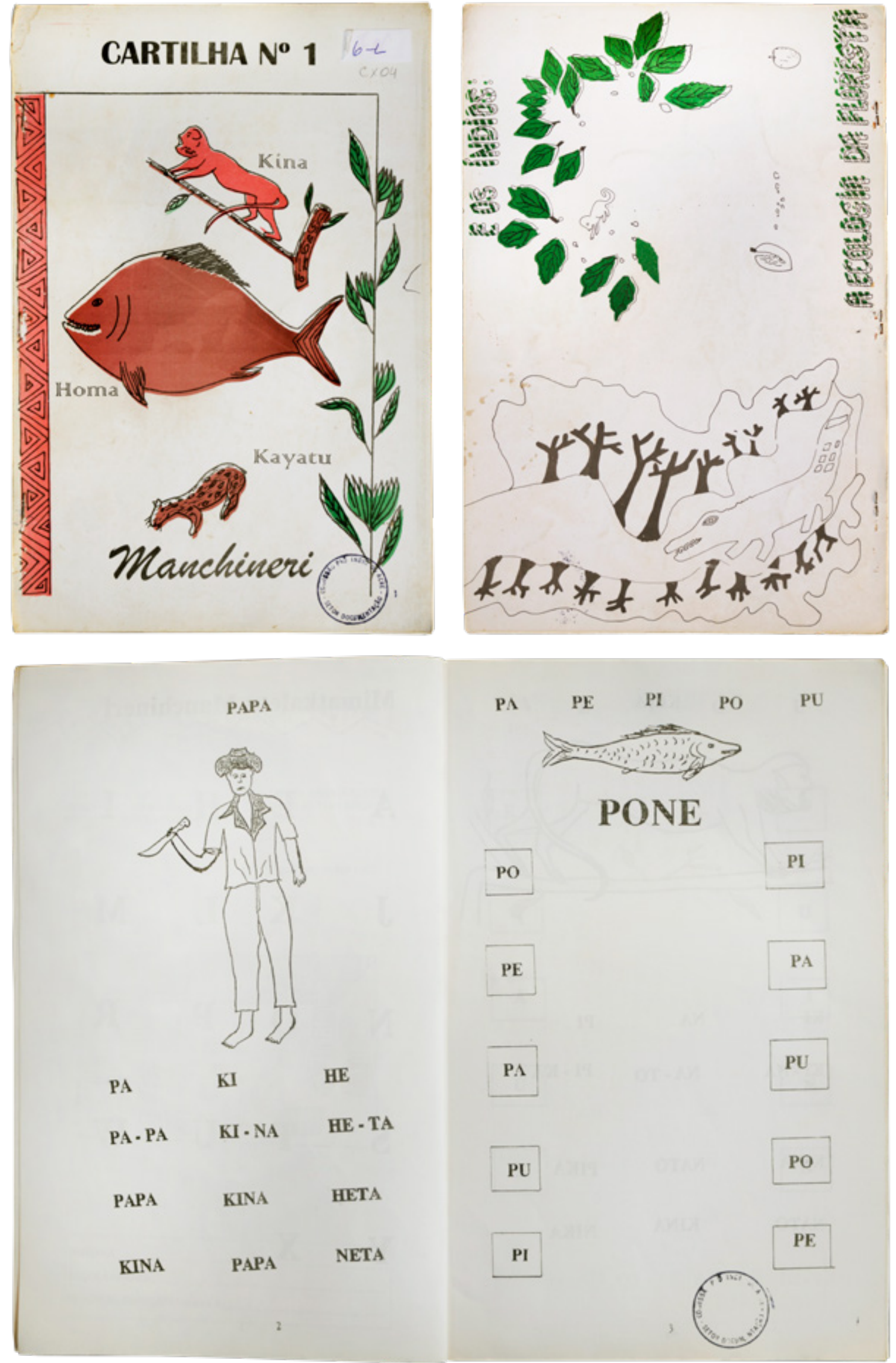

Figuras 93, 94 e 95: Primeira capa, quarta capa e páginas do miolo de Cartilha $N^{\circ} 1$ Manchineri (1997). A quarta capa é uma impressão não finalizada da capa de outra apostila, prática comum na produção dos impressos dessa época. Segundo Janio (2019), o objetivo era aproveitar o papel disponível, por razões econômicas. Fonte: Pesquisa de campo, Paiva (2019). 


\title{
3.3. De 2000 a 2008: diversificar e aprimorar
}

A partir de 2001 os livros passam a ser impressos em gráficas particulares diversas e se encerra a parceria com a Gráfica Poronga (que dura de 1998 a 2000), e a estética que havia se consolidado por toda a década anterior é deixada para trás. Concomitantemente, designers profissionais externos à equipe da CPI-AC passam a ser contratados para o desenvolvimento dos projetos, passando a assinar a diagramação e o projeto gráfico dos livros (embora às vezes Gavazzi ainda figure creditado em conjunto pelo projeto gráfico ou pela "revisão editorial", mas em raros casos). Pode-se supor que há uma relação de causalidade aqui, já que a necessidade de formatar e enviar arquivos digitais preparados para impressão para as gráficas demanda um conhecimento técnico que não era dominado pela equipe, treinada nas formas que, naquela época, já eram consideradas datadas para composição e reprodução gráfica, e insatisfeita com algumas experiências problemáticas ainda no final da década de 1990, como mencionado anteriormente.

Segundo Sena, havia, também, uma intenção de trazer uma "qualidade gráfica" maior para os projetos dos livros, em particular com base em produções de outros projetos de natureza semelhante e com a experiência da produção de Antologia da Floresta (1997) com a editora Multiletra.

\begin{abstract}
Daí depois, eu acho, da beleza desse de 1997, o Antologia acho que é de 1997, né? Ele é bem antigo. Depois da beleza dele, a gente não quis mais fazer sem artista gráfico, não. Porque aí, também, outros projetos do Brasil já estavam fazendo mais profissionalmente, mesmo, mesmo que esses tenham uma coisa linda, romântica, de ser doméstica e não sei o que, eles são todos naif... os projetos gráficos dos livros, eles são todos mais originais assim, no sentido de que tem muito pouca intervenção do artista gráfico e nossa, então ele tem uma beleza, assim, de ser a autoria pura, o preciosismo, meio cru. E depois de 1997 quando a gente viu aquela beleza do Antologia e outros projetos também - porque tem outros projetos de educação no Brasil que já começaram assim, bombando. Em termos de qualidade gráfica, sabe. Tanto de projeto gráfico quanto de impressão. (SENA, 2020)
\end{abstract}

Dessa forma, esse é um período de transição na configuração visual dos livros. Até, mais ou menos, 2001, tem-se ainda publicações (muitas das quais são reedições de livros originalmente publicados em anos anteriores, cujas primeiras edições foram produzidas pela Gráfica Kene Hiwe) muito semelhantes à estética explorada durante os anos 1990 - ilustrações com cores chapadas e vibrantes, diagramação simplificada e pouco uso de fotografia. A partir de 2001, todos os miolos são coloridos, assim como as capas, o que não ocorria na produção da Gráfica Kene Hiwe. O barateamento dos serviços de impressão certamente contribui para esta virada produtiva. Os projetos passam a ser mais variados entre si, já que dependem do direcionamento de cada coordenador e de sua relação com o designer responsável, o que, em contraponto com a situação prévia, onde um diagramador (Jânio) era responsável pela formatação de todos os layouts, gera uma mudança significativa.

Então, se antes as capas dos materiais, por exemplo, eram todas compostas por ilustrações, agora tem-se montagens fotográficas, texturas, colagens, artifícios gráficos que não eram utilizados anteriormente. A variedade de tipografias utilizadas nas capas aumenta significativamente, assim como recursos tais como boxes, faixas, texturas. Os formatos passam a ser mais variáveis e menores, em comparação com as apostilas em ofício pro- 

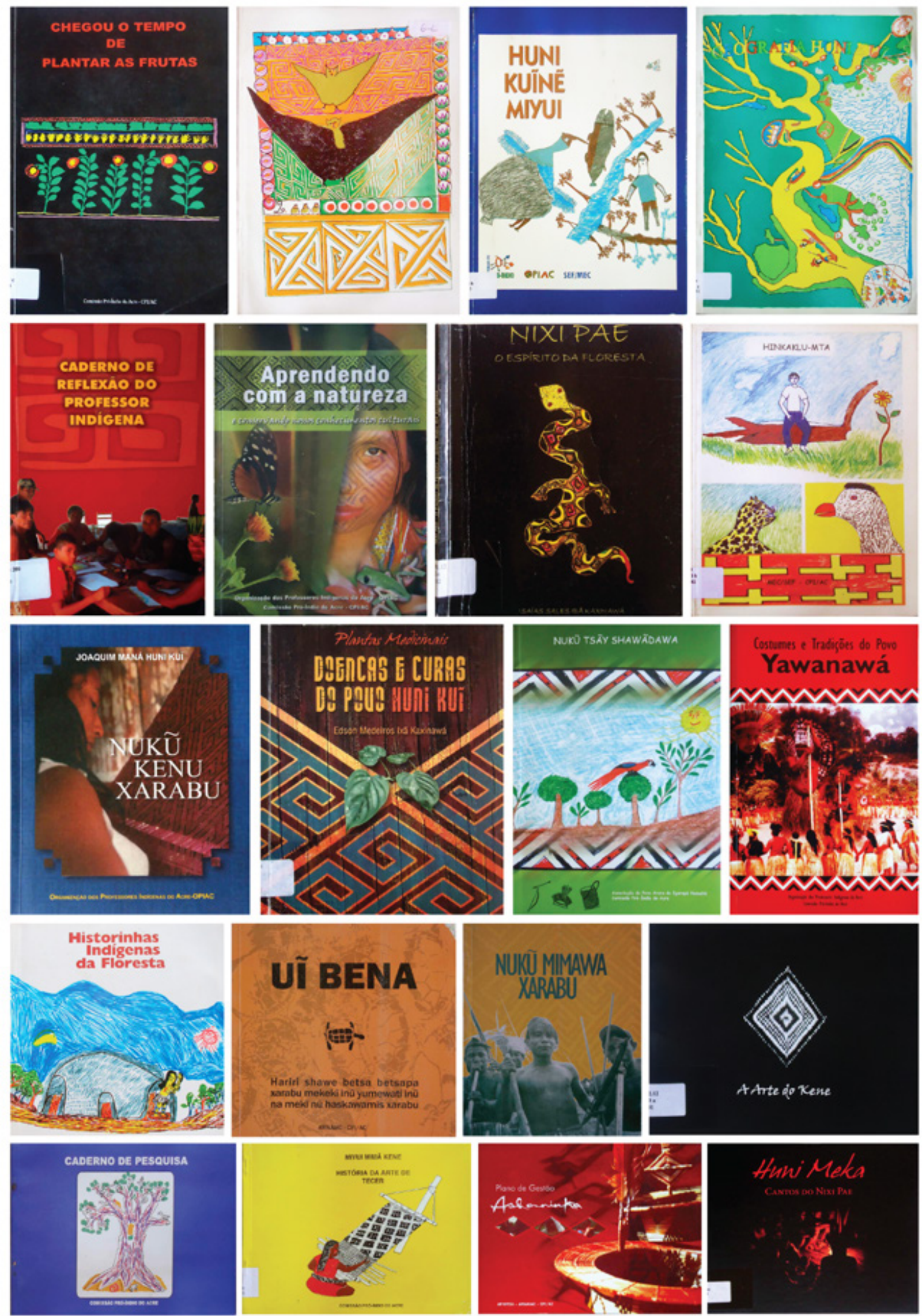

Figura 96: Capas de livros publicados pela CPI-AC entre 2000 e 2008. Da esquerda para a direita, de cima para baixo: Chegou o Tempo de Plantar as Frutas $2^{\circ}$ ed. (2000), Kene $2^{\circ}$ ed. (2000), Huni Kuĩnẽ Miyui (2002), Geografia Huni Kuĩ (2001), Aprendendo com a Natureza e Conservando Nossos Conhecimentos Culturais (2006), Nixi Pae - O Espírito da Floresta (2006) Hinkaklu - MTA (2001), Nukũ Kenu Xarabu (2006), Plantas Medicinais - Doenças e Curas do Povo Huni Kuĩ (2006), Nukũ Tsãy Shawãdawa (2007), Costumes e Tradições do Povo Yawanawá (2007) [continua na página a seguir]. 
duzidas durante os anos 1990. A encadernação agora é colada, e não mais grampeada. As capas e imagens são impressas em policromia com retícula, como é comum na impressão offset profissional.

As fotografias também passam a ser mais utilizadas, competindo com as ilustrações pelo maior espaço nos livros. Ainda assim, nos livros produzidos até 2008, a ilustração mantém um papel de destaque, estando presente na grande maioria dos livros - apenas 4 títulos produzidos no período não possuem ilustrações, uma quantidade que, apesar de pequena, é grande ao ser comparada com os dados dos períodos anteriores: de 1983 a 2000 apenas um livro não possui ilustrações.

Já com relação às temáticas abordadas, as pesquisas sobre aspectos culturais de cada etnia ganham mais destaque, em particular para os kaxinawá. Durante esses oito anos, foram publicados 25 livros, dos quais 10 são especificamente kaxinawás. Apenas 4 livros desse total são escritos por autores de e voltados para mais de uma etnia, como era mais comum até o final da década de 1990. Tem-se também menos materiais de autoria coletiva (mesmo que de uma mesma etnia), já que muitos professores e pesquisadores que haviam iniciado sua formação no começo do projeto estavam em estágios mais avançados da autoria e da prática de estudo e análise, desenvolvendo pesquisas por conta própria sobre suas respectivas culturas, como é o caso dos "cadernos de pesquisa": Nukũ Kenu Xarabu, de 2002, levantamento do professor Joaquim Paulo de Lima Maná sobre a tecelagem kaxinawá; Plantas Medicinais - Doenças e Curas do Povo Huni Kuĩ, lançado em 2006 e reeditado em 2009, do professor Edson Medeiros Ixã Kaxinawá; e Nixi Pae - O Espírito da Floresta, um levantamento dos mitos e cantos do ritual kaxinawá para consumo da ayahuasca ${ }^{11}$ feito pelo professor Isaías Sales Ibã Kaxinawá e publicado em 2006.

Outra questão específica desse período (especificamente a partir de 2002, quando todos os livros produzidos passam a ser diagramados por profissionais externos à entidade) é a relação entre a equipe da CPI-AC, nesse caso os coordenadores dos projetos dos livros, com os designers contratados para o desenvolvimento dos projetos. Para essa pesquisa foi possível entrevistar dois designers que trabalharam com a CPI-AC: Guilherme Noronha ${ }^{12}$ e Maurício de Lara Galvão ${ }^{13}$. A informações compiladas a seguir são uma síntese do cruzamento entre esclarecimentos derivados das entrevistas com os designers e os coordenadores de projetos da CPI-AC.

É importante salientar que, ainda nesse período, não havia um método único para o desenvolvimento dos projetos gráficos, ou mesmo para o contato com os designers. Ainda assim, considera-se a ser possível compreender alguns dos principais fatores e posicionamentos adotados pela entidade.

A seleção e contratação do profissional responsável pelo projeto gráfico de determinado livro ficava a cargo do coordenador do projeto (conforme mencionado anteriormente, o ou os membros da CPI-AC que encabeçavam

11 Banisteriopsis spp., também chamada de cipó, daime, santo daime, e nixi pae para os Kaxinawá. Planta com efeitos alucinógenos com a qual se prepara bebida considerada sagrada, consumida em rituais.

12 Formado em publicidade pela Escola Superior de Propaganda e Marketing de São Paulo, é especialista em design editorial, webdesign e no desenvolvimento de identidades visuais. Também atua como fotógrafo profissional. Junto a ONGs e iniciativas diversas, desenvolveu um grande número de projetos gráficos e editoriais voltados para populações indígenas brasileiras.

13 Formado em Produção Visual Gráfica pelo SENAI- SP, possui vasta experiência profissional como designer e diagramador. Foi responsável pela diagramação de Plantas Medicinais - Doenças e Curas do Povo Huni Kuĩ, e Aprendendo com a Natureza e Conservando Nossos Conhecimentos Culturais (ambos de 2006).
Figura 96:

[continuação]

Historinhas Indígenas

da Floresta $2^{\circ}$ ed.

(2001), Uĩ Bena (2006)

Nukũ Mimawa Xarabu

(2006), A Arte do

Kene (2006), Caderno

de Pesquisa $2^{\circ}$ ed.

(2000), Miyui Mimã

Kene - História da Arte de Tecer (2000), Plano de Gestão Ashaninka (2007), Huni Meka

(2007). Fonte: Pesquisa de campo, Paiva (2019). 

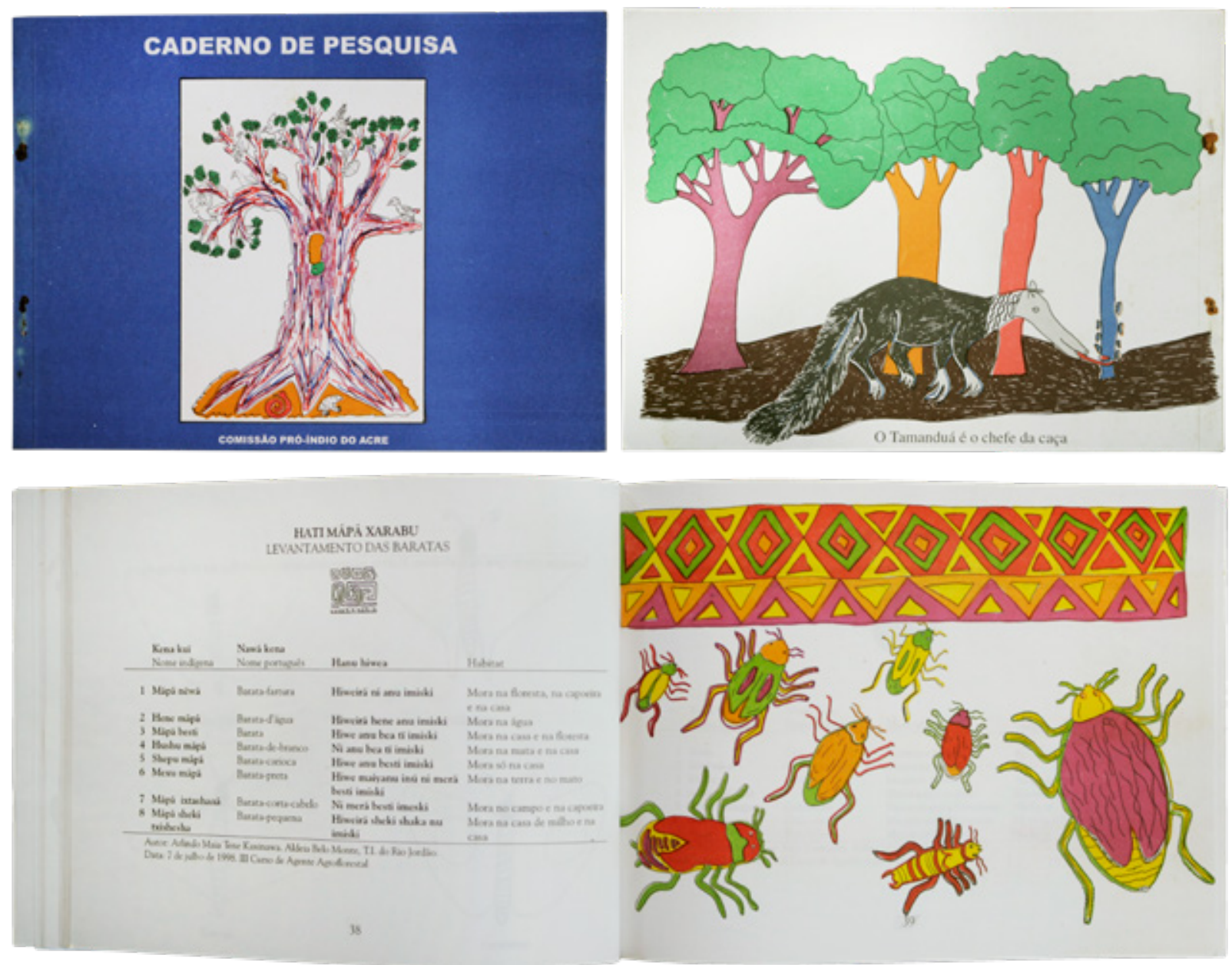

Figuras 97, 98 e 99: Primeira e quarta capas e páginas do miolo de Caderno de Pesquisa $2^{\circ}$ ed. (2000). Fonte: Pesquisa de campo, Paiva (2019) o desenvolvimento da publicação). É perceptível pelas fichas de créditos dos livros uma tendência à repetição de profissionais, ou seja, uma vez que o designer trabalha a primeira vez com a entidade, há uma grande possibilidade de que isso se repita. Entende-se que se dava preferência a pessoas já conhecidas, que já haviam tido alguma experiência junto à CPI-AC.

A não ser pelas segundas edições de materiais cujas primeiras edições datam da década de 1990, os livros apresentam formatos reduzidos - em comparação com o formato ofício utilizado anteriormente. $O$ formato era, via de regra, estabelecido pela própria CPI-AC, não ficando ao encargo do designer. Entende-se que, além das restrições orçamentárias, alguns fatores específicos eram considerados pela equipe para a definição das medidas do impresso - inclusive nos casos em que o designer possa ter vindo a sugerir determinada configuração.

A gente orientava, sim, e o formato ficava mais por conta... mas uma das coisas, por exemplo, que a gente olha, é o tamanho do livro, o tamanho do livro tem que caber na bolsinha do estudante indígena. Você não pode ter um livro que seja ruim pra ele levar pra escola. Muitos deles tem que pegar canoa, pegar barco, passar em varadouros...

A gente tem que tá dialogando também com as condições de terra indígena, que é floresta né, é úmido, não pode ser um material difícil de levar pra escola. Se ele quer levar pra casa, ele tem que levar, se ele quer circular na aldeia, tem que circular. Então essas coisas também influenciam muito no tamanho. $\mathrm{E}$ também, a gente 
sempre pensou o tamanho e de um período pra cá pensou mais, o tamanho também tem que ser funcional. Por exemplo, a Secretaria de Educação só dá carteira de braço, não dá mesa pras escolas, então dependendo do tamanho do livro ele é super inadequado para ser usado naquelas mesas de braço. Se fosse uma mesa normal, assim, desse tamanho, era melhor. Então também a gente pensou nisso, se a Secretaria de Educação manda aquelas carteiras de braço, como a gente chama aqui no Acre, um livro desses tem que ser adequado. E fomos pensando nessas coisas. (SENA, 2019)

Algumas questões técnicas sensíveis dizem respeito à resolução das imagens e à tipografia. A começar pelas imagens, problemas com resolução e com a digitalização das ilustrações continuam sendo um impasse. Apesar de não haver casos tão perceptíveis quando o exemplo supracitado da segunda edição de Aprendendo Português nas Escolas da Floresta (1997), ainda é possível encontrar imagens com resolução insuficiente em materiais de 2005 (Yawanawahãu Wixi) - embora não com uma frequência alarmante, ao ponto de ser uma característica definidora dos livros produzidos no período. Este é um tópico comumente citado pelos entrevistados ao se referirem aos obstáculos apresentados no desenvolvimento dos projetos gráficos do período.

Até porque nos primeiros livros, eles tiveram um problema com a resolução de imagem. Eles não tinham muita noção e aí iam para campo com pouco espaço para gravar fotos, ou então as fotos eram escaneadas, muita coisa era feita em filme e aí [as fotos] eram escaneadas em baixa resolução. Então assim, era muito limitado e isso daí limitava o tamanho que as fotos iam aparecer nas publicações. Então logo nos primeiros livros, como eu tive essa limitação de tamanho, não podia ampliar muito a foto, isso refletiu no resultado da publicação. E refletiu com certeza, na avaliação, depois que o trabalho ficou pronto. Então, se você pegar o livro dos Yawanawa. Você chegou a ver ele?

Eu tive que fazer milagre com esse livro aí, porque as imagens eram terríveis, terríveis e depois eu sentei com a $\mathrm{Malu}^{14}$ e falei: Malu, esse livro aqui a gente não pode mais fazer isso, sabe, a gente tem que explorar essas fotos, temos que aumentar isso daí. E foi a partir dessa conversa, desses primeiros livros, que foi aprendendo, que foi o Iawanawá, que têm fotos pequenas. Foi a partir daí que surgiu logo em seguida o projeto do primeiro PGTA [Plano de Gestão Territorial e Ambiental], se eu não me engano dos Ashaninka. Que aí a gente começou a explorar fotos de página inteira. Então assim, apesar de isso daí ter vindo deles foi, com certeza, o reflexo de uma experiência que nós tivemos anteriormente de um feedback que eu passei para eles como resultado de projetos anteriores. (NORONHA, 2019)

E tive que manter os desenhos. O que eu fiz? Foi pegar aqueles desenhos, que muitos deles já estavam ruins assim, mal... como é que eu posso dizer? Mal digitali-

14 Maria Luiza Pinedo Ochoa, parte da equipe do programa de políticas públicas e articulação regional da CPI-AC, organizadora/coordenadora de diversos livros da Coleção Autoria Indígena. 
Figuras 100, $101 \mathrm{e}$ 102: Primeira capa e páginas do miolo de Historinhas Indígenas

da Floresta $2^{\circ}$ ed. (2001). Fonte: Pesquisa de campo, Paiva (2019). zados. Quer dizer, eu retoquei no Photoshop. Eu dei um reforço no Photoshop. Eu apliquei múltiplas camadas para reforçar as cores naturais deles. Eu não adulterei os documentos, de forma alguma. Eu só resgatei, que nem fosse um trabalho de limpeza numa foto. Quem tem Photoshop consegue fazer isso. (GALVÃO, 2019, referindo-se às ilustrações de Plantas Medicinais - Doenças e Curas do Povo Huni Kuĩ, de 2006)

Como anteriormente as ilustrações eram reproduzidas manualmente para a gravação das matrizes, sua formatação seguia o formato necessário para sua impressão. Ou seja, se havia uma ilustração original muito pequena ou muito grande para sua utilização em uma página específica, compondo o layout com o texto, a pessoa responsável pela "transcrição gráfica" daquele material a redesenhava, proporcionalmente, no formato adequado. Por outro lado, se uma ilustração foi escaneada em uma resolução inadequada, ao utilizar tal imagem na diagramação final, é possível que hajam distorções daquela imagem. Desse modo, o problema deriva tanto do profissional res-
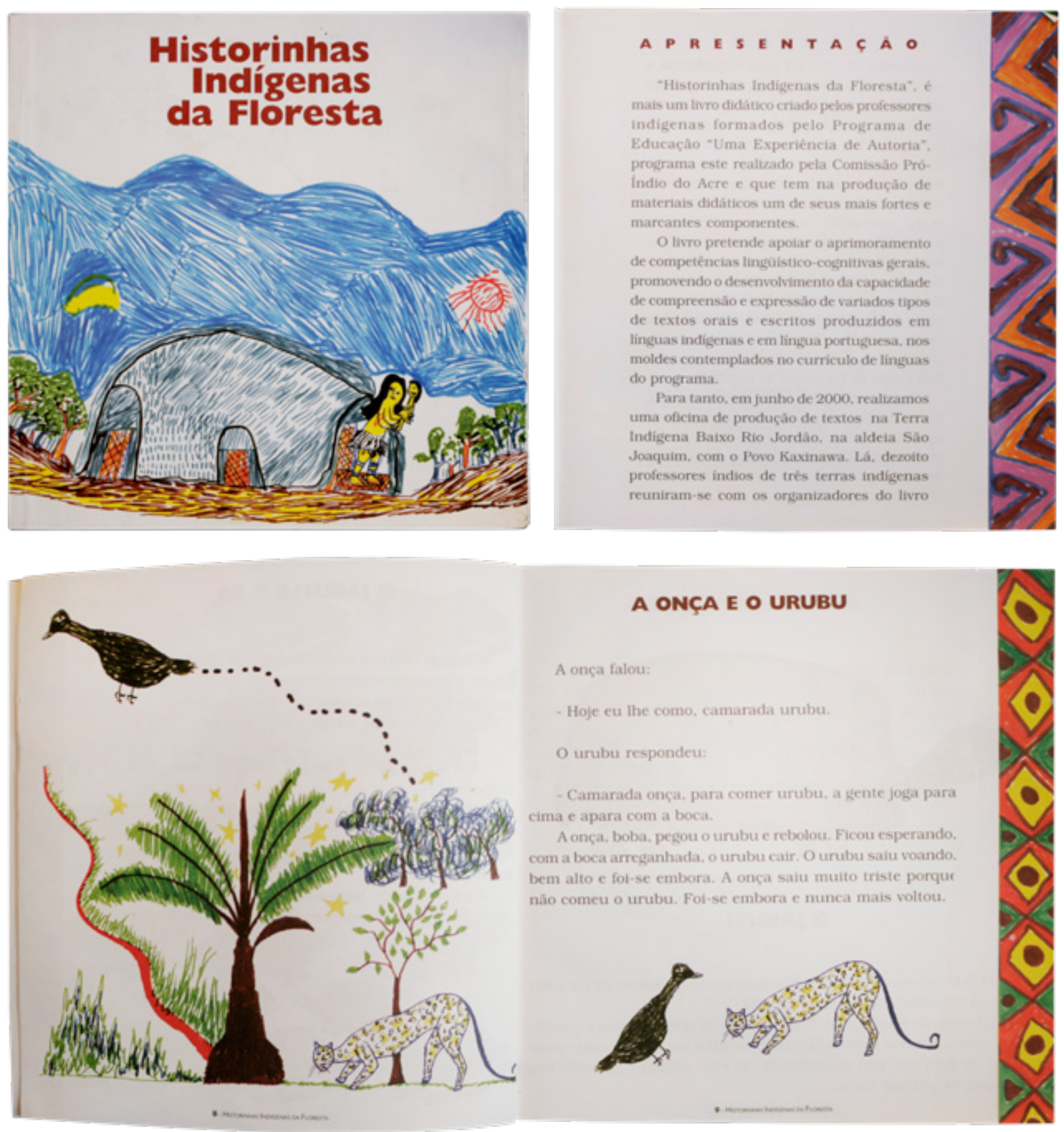

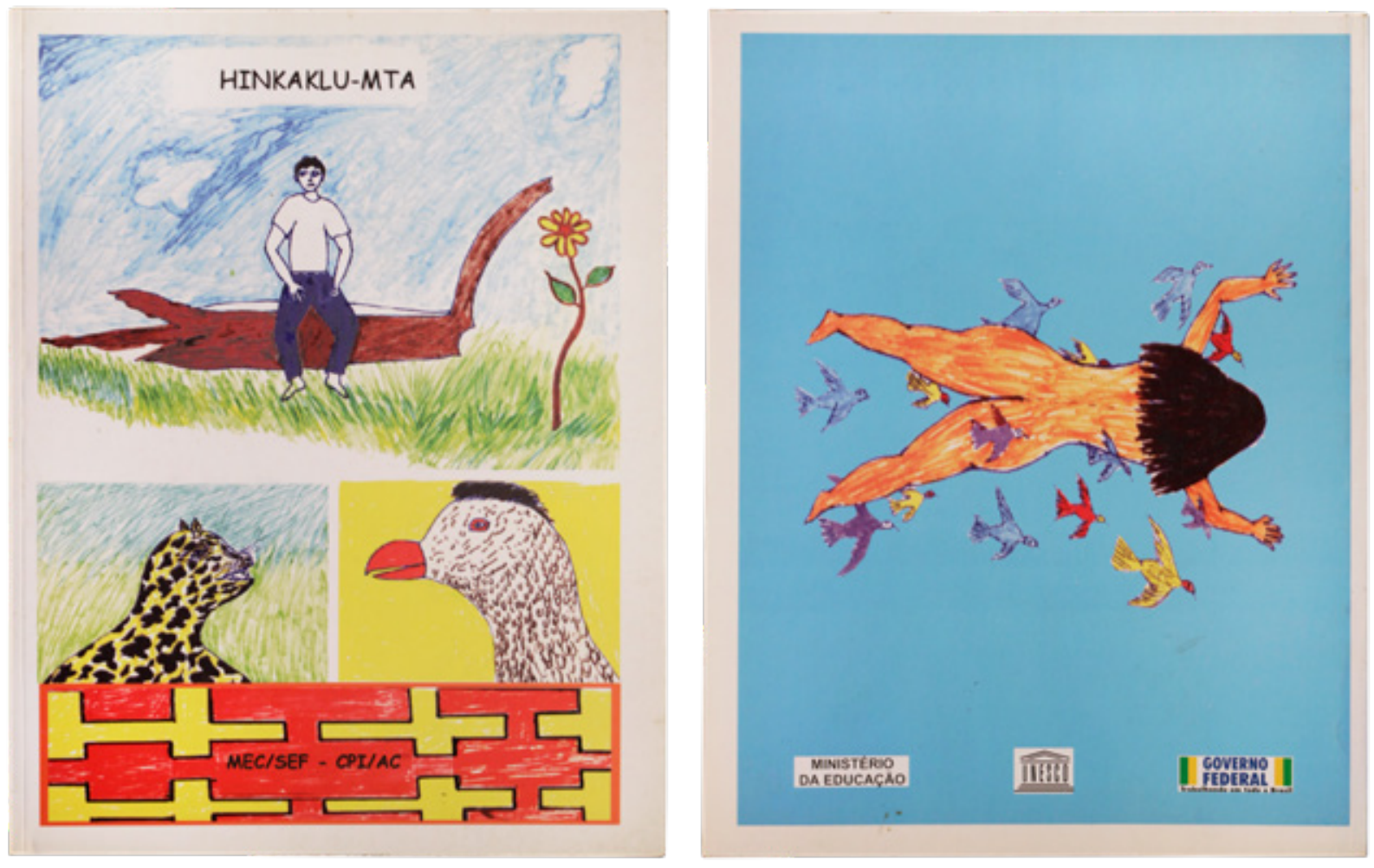

ponsável pela digitalização da imagem quanto do designer, que a aplica em um formato não condizente com sua configuração técnica. Outra questão semelhante é a das texturas. Os desenhos, quando "transcritos", ganhavam cores e contornos sólidos e mais homogêneos, já que a própria impressora não era capaz de produzir gradientes e variações (apenas cores chapadas). Figuras 103 e 104: Primeira e quarta capas de Hinkaklu - MTA (2001). Fonte: Pesquisa de campo, Paiva (2019) Com a digitalização, as texturas que fazem parte do desenho passam a ser impressas, o que causa uma heterogeneidade geral entre as ilustrações de um mesmo material - algumas terão linhas mais definidas, outras menos, algumas terão texturas de lápis de cor, outras de canetas hidrocor.

Segundo Gavazzi, outra questão importante a ser considerada era o grande volume de trabalho exercido pela equipe da CPI-AC, que impossibilitava uma maior dedicação à coordenação dos projetos dos livros, às vezes prejudicando o resultado final da publicação.

Depois, quando começaram a participar com fotografia, com imagem fotográfica, muitas vezes havia problemas com imagens de baixa resolução.

(...) É, péssimo, tem umas fotos horrorosas. As ilustrações em baixíssima resolução. Aconteceu muito isso. Então depende de quem estava fazendo a orientação. E, também, que a gente não tinha uma pessoa só para ver isso, e a quantidade de trabalho era enorme. (GAVAZZI, 2019)

A respeito das tipografias utilizadas para os miolos, no caso específico dos conteúdos em línguas indígenas, é necessário considerar a questão dos diacríticos específicos que são utilizados, e que não existem na língua portuguesa ${ }^{15}$. Nos materiais elaborados nos primeiros anos, datilografados em máquinas de escrever, este não era um problema, já que a máquina possibilita a aplicação de diacríticos em quaisquer caracteres. Já após a aquisição

15 Algumas interessantíssimas pesquisas foram realizadas sobre a temática do design tipográfico e as línguas indígenas, das quais salienta-se Diniz (2007), Silva e Silva (2014) e Garone (2006). 
de computadores, nos materiais produzidos na gráfica interna, percebe-se que tais sinalizações eram inseridas de forma manual, diretamente desenhados nas matrizes para impressão.

Segundo Sena, em meados da década de 1990, com o auxílio de técnicos em informática, a CPI-AC pode desenvolver uma fonte que se adequasse a estas questões específicas, especialmente relacionadas à língua do povo Kaxinawá, o Hãxta kuĩ. Nem todas as línguas indígenas das etnias atendidas pelo projeto de educação fazem uso de diacríticos, como é o caso das línguas das etnias Yawanawa, Katukina e Shanenawa, além dos supracitados Kaxinawá - ressaltados devido ao maior volume de materiais publicados em Hãxta kuĩ - todos da família linguística Pano, e Arara, da família Karib. A Coleção Autoria Indígena também abrange materiais publicados em Yawanawa e Katukina, e, em menor quantidade, Jaminawa, não havendo nenhum material em língua Shanenawa.

O pessoal da informática, junto com o pessoal da linguística - os professores Kaxinawá, que participavam dos cursos de formação - passaram a realizar pesquisas sobre como se poderiam acentuar as vogais específicas [da língua Hãxta kuĩ] que não se usa na língua portuguesa. Aí, naquela época, eles criaram um programinha para colocar esses acentos. Naquela época era uma coisa difícil de fazer. Mas foi isso, o pessoal da informática, que prestava assistência técnica para a CPI-AC, com os indígenas, o Joaquim Maná, que nessa época já era estudioso de linguística... Aí programaram os computadores da CPI-AC para poder usar. E os professores, quando tinham aula de informática, já digitavam direto na língua, em Hãxta kũ̃. Era o maior barato. (SENA, 2020, comunicação oral via telefone)

Figuras 105 e 106: Primeira e quarta capas de Nukũ Mimawa Xarabu (2006). Fonte: Pesquisa de campo, Paiva (2019)
A tipografia desenvolvida neste processo era repassada aos designers responsáveis pelos projetos de livros em língua indígena - no período em questão foram produzidos volumes em hãxta kuĩ, yawanawa, arara e manchineri, sendo que esta última não faz uso de diacríticos. Segundo Noronha, no caso específico dos materiais em hãxta kuĩ, a tipografia era uma adapta-
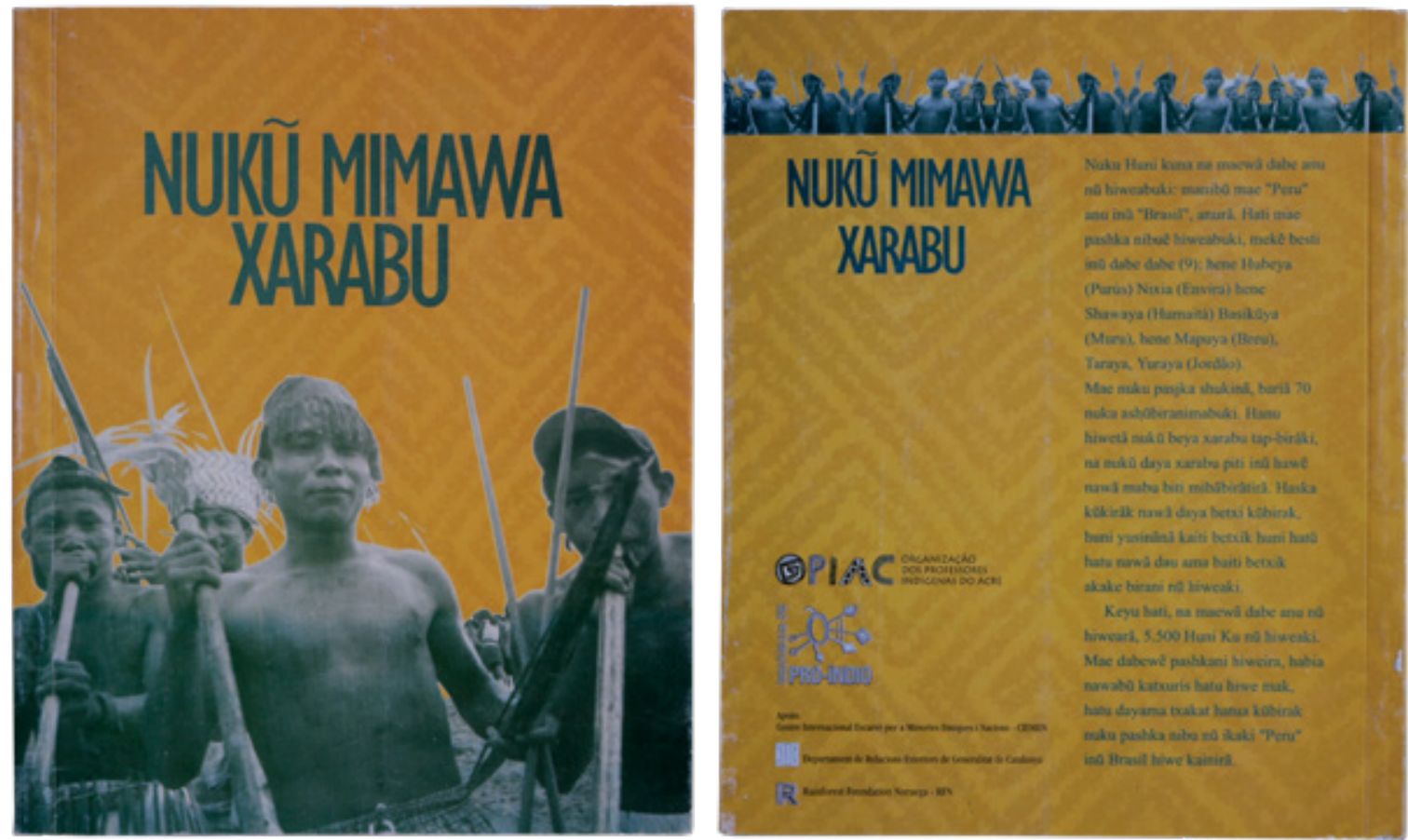

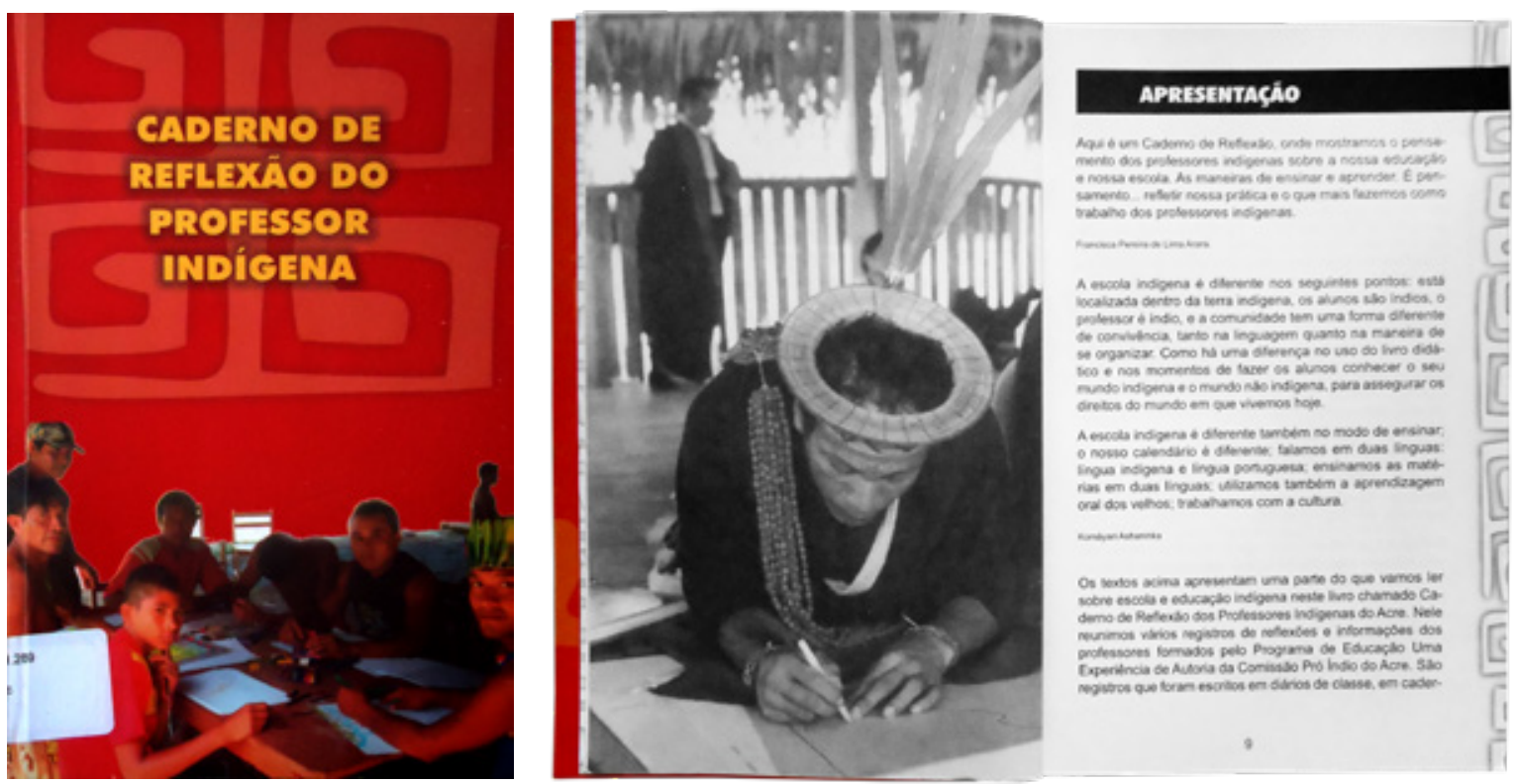

ção da fonte Times New Roman. Já para os títulos, os designers entrevistados relatam que optavam por escolher outras fontes e realizar a aplicação dos diacríticos necessários manualmente.

Olha, no começo era bem complicado porque eles mandaram desenvolver uma fonte TTF que tinha esses caracteres, que era uma fonte derivada da Times New Roman.

Figuras 107 e 108: Primeira capa e páginas do miolo de Caderno de Reflexão do Professor Indigena (2005). Fonte: Pesquisa de campo, Paiva (2019).

(...) A própria CPI que mandou desenvolver. Ela chegou para algum designer que sabiam fazer isso, isso tem muito tempo, nós estamos falando aí de quinze anos atrás.

E o cara pegou a Times New Roman, pegou esses caracteres aí "e", "u", colocou os acentos e entregou lá para eles, tinha inclusive o código para você usar, enfim, era limitado porque o texto vinha digitado por eles nessa fonte $\mathrm{e}$ aí eu era obrigado a utilizar essa fonte nos textos.

(...) Quando falava de títulos, aí eu optava por fazer os títulos em outras fontes e acentuar as palavras na mão. Mas é só porque eram títulos e era mais fácil, porque eram poucas letras que eu tinha que acentuar na mão, mas eu acentuava na mão. (NORONHA, 2019)

Então. Me foi passado uma tipologia que já estava pronta para suportar esse tipo de interferência. Uma tipologia deles, que eles criaram, que algum técnico criou e adaptava à língua. Eu não sei se foi a CPI. Eu só sei que era uma tipologia que me deram que eu nuca vi em lugar nenhum e que eu não me lembro do nome dela. E o que não tinha eu me lembro que eu tive que montar. Botar o pinguinho ali na unha. (GALVÃO, 2019)

Já no material impresso em língua Arara, a tipografia parece ser uma adaptação, provavelmente feita de modo semelhante, da fonte Comic Sans, utilizada em outros materiais do período, como Hinkaklu - MTA, de 2001.

As fotografias e ilustrações utilizadas nos materiais continuavam sendo selecionadas pela equipe da CPI-AC, e repassadas aos designers já com orientações sobre o momento de sua inserção específica no material. Em alguns casos, era possível que o designer escolhesse entre algumas opções compartilhadas pela equipe. 

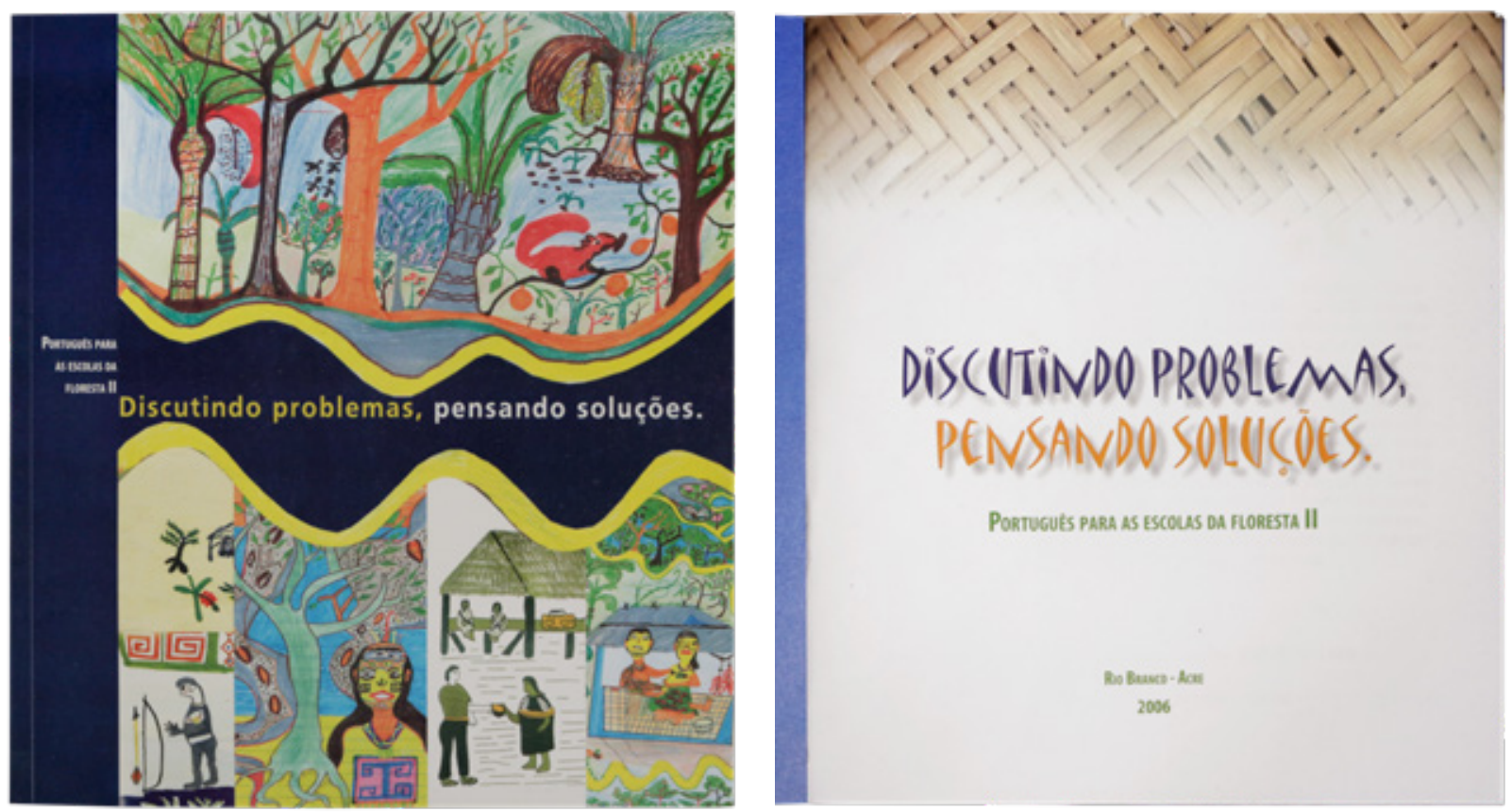

Figuras 109 e 110: Primeira capa e folha de rosto de Discutindo Problemas, Pensando Soluções (2007). Fonte: Pesquisa de campo, Paiva (2019).
Na maioria dos casos eles falavam assim: essa foto nessa parte, essa outra nessa outra parte. No máximo, no máximo, alguns momentos vinham assim: nessa daqui você pode escolher entre essas duas ou três. No máximo, mas assim, na maioria das vezes eles já determinavam que essa foto vem em tal lugar, uma coisa bem engessada mesmo, bem predeterminada, predefinida. (NORONHA, 2019)

Não. Eles têm um briefing. O briefing é assim. Esse texto tem que acompanhar essa imagem. Geralmente já vem associado. Ou então eles falam assim: "as imagens são essas. As legendas das imagens são essas". E você se vira e associa. Depende do povo que está lá e está te assessorando. Mas eles têm um padrão. Tem que dar destaque para o desenho do índio. E ilustrar aquele... isso é uma regra deles. Ilustrar aquilo lá com coisas que os índios produziram. Você vai ser um montador e um valorizador do que eles fizeram. Você não vai criar da sua cabeça assim no sentido... Eu não vou criar um kene novo. Eu não vou criar um desenho novo. Eu não vou acrescentar um desenho novo. No máximo combinar o que já existe. Combinar ou melhorar, dar destaque, tratar de outra forma, usar como fundo, usar como marca d'água. Seja o que for que você quiser fazer, mas é dentro daquilo que eles já desenharam. Eles são muito claros. E eles têm uma diagramação também que eles costumam cumprir: "olha. Esse desenho aqui é aqui. Tem que seguir assim". Então é muito assim, para não fugir. (GALVÃO, 2020)

Já para a composição das capas os designers tinham uma maior liberdade criativa e propositiva (NORONHA, 2019, GALVÃO, 2019), podendo desenvolver montagens fotográficas e composições tipográficas com uma maior diversidade de fontes. Nos livros produzidos neste período encontram-se tanto capas mais simples, compostas por apenas uma imagem (fotografia ou ilustração) e a composição verbal do título, quando capas com composições mais complexas, que combinam várias imagens e texturas. 


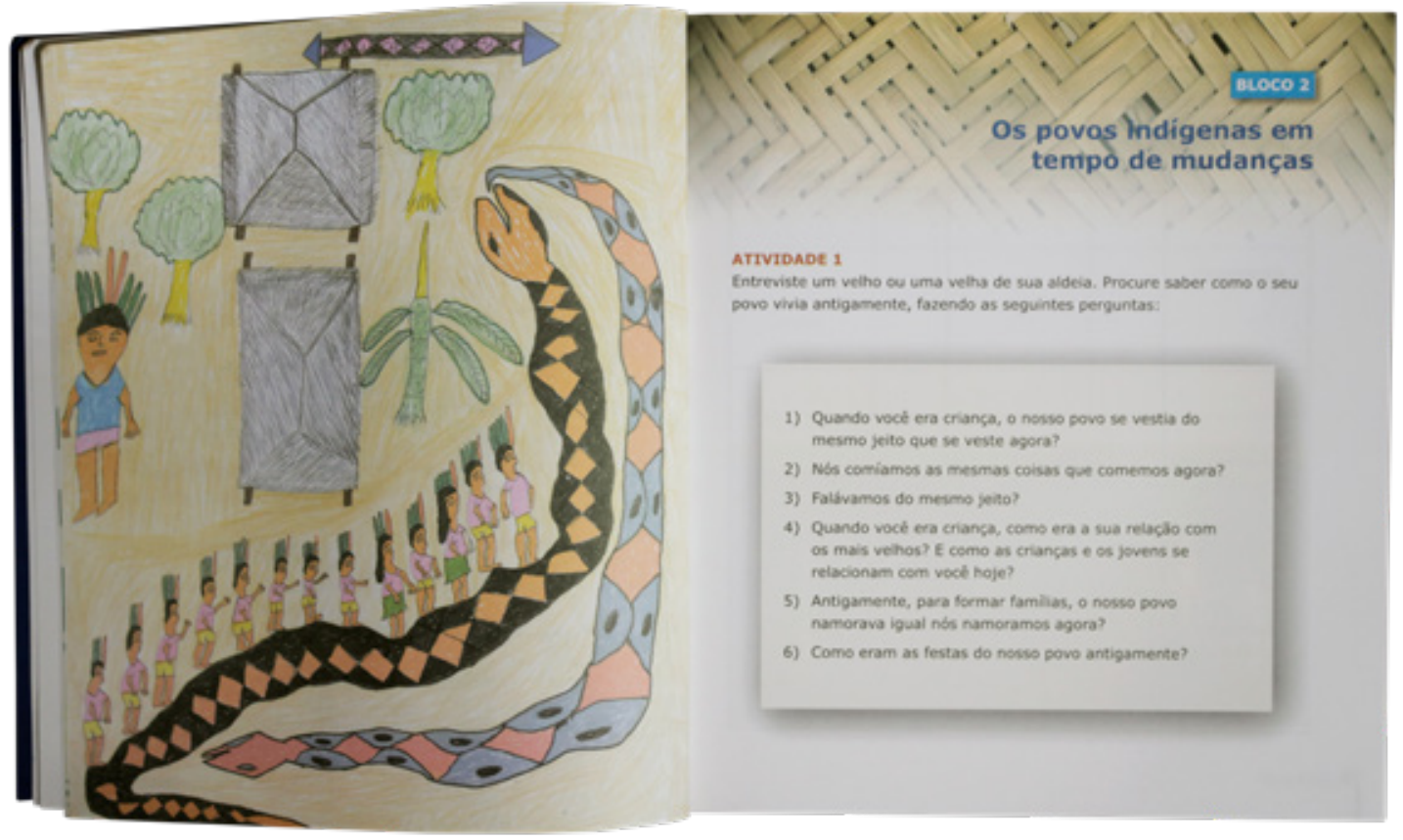

Os direcionamentos para a realização do projeto gráfico, apesar de variantes de acordo com a coordenação do projeto, parecem ser bem diretos em termos do que se espera daquele material, especialmente no caso dos livros organizados por Sena, Gavazzi e Monte. Alguns encaminhamentos comuns que podem ser percebidos, tanto ao se observar o resultado dos livros quanto nas informações compartilhadas nas entrevistas são: a valorização de composições simples, com elementos e recursos gráficos reduzidos e utilizados de modo eficiente; o destaque às ilustrações; e a utilização pontual de grafismos e kene.

Direcionamento de projeto gráfico quase sempre o coordenador que contratou o artista gráfico não dá, ele dá o conteúdo e as imagens e o artista gráfico faz. No caso meu, do Renato e da Nietta, que a gente organiza muito material - a Nietta não mais, porque ela saiu, se aposentou, mas organizou muitos. Tu sabe né? A gente fala tudo como a gente quer. A gente quer assim, nesse tamanho, pensa assim. A gente troca com o artista gráfico, porque a gente quer participar também da elaboração do projeto. A gente não sabe executar o projeto gráfico, mas a gente sabe o tamanho da foto, que não fique muito grande, desproporcional, excesso de grafismo, fica poluído, a gente quer mais clean, a gente quer isso, quer aquilo. Então a gente, que é do conselho editorial, a gente tem mais experiência com isso. $\mathrm{O} \mathrm{Re}-$ nato tem muito bom gosto. O Renato é um artista, ele é escultor, ele faz mosaico, então ele é artista. Eu aprendi, entendeu, a escolher os desenhos, eu tenho um olho pra cor, pro tamanho, pros excessos, eu desenvolvi um estilo clean, eu conto os elementos gráficos, por exemplo, a gente já teve caso aqui, anos atrás, de um artista gráfico apresentar em uma página 16 elementos gráficos diferentes. A letra, mais a foto, mais um grafismo, mais um não sei o que. Em banner, nos já contamos banner com 32 elementos gráficos, super poluído, a gente não sabe o que aquele banner quer comunicar. Então, eu desenvolvi isso. E a gente dialoga muito com o artista gráfico no projeto gráfico. (SENA, 2019)

Figura 111: Páginas do miolo de Discutindo Problemas, Pensando Soluções (2007). Fonte: Pesquisa de campo, Paiva (2019). 

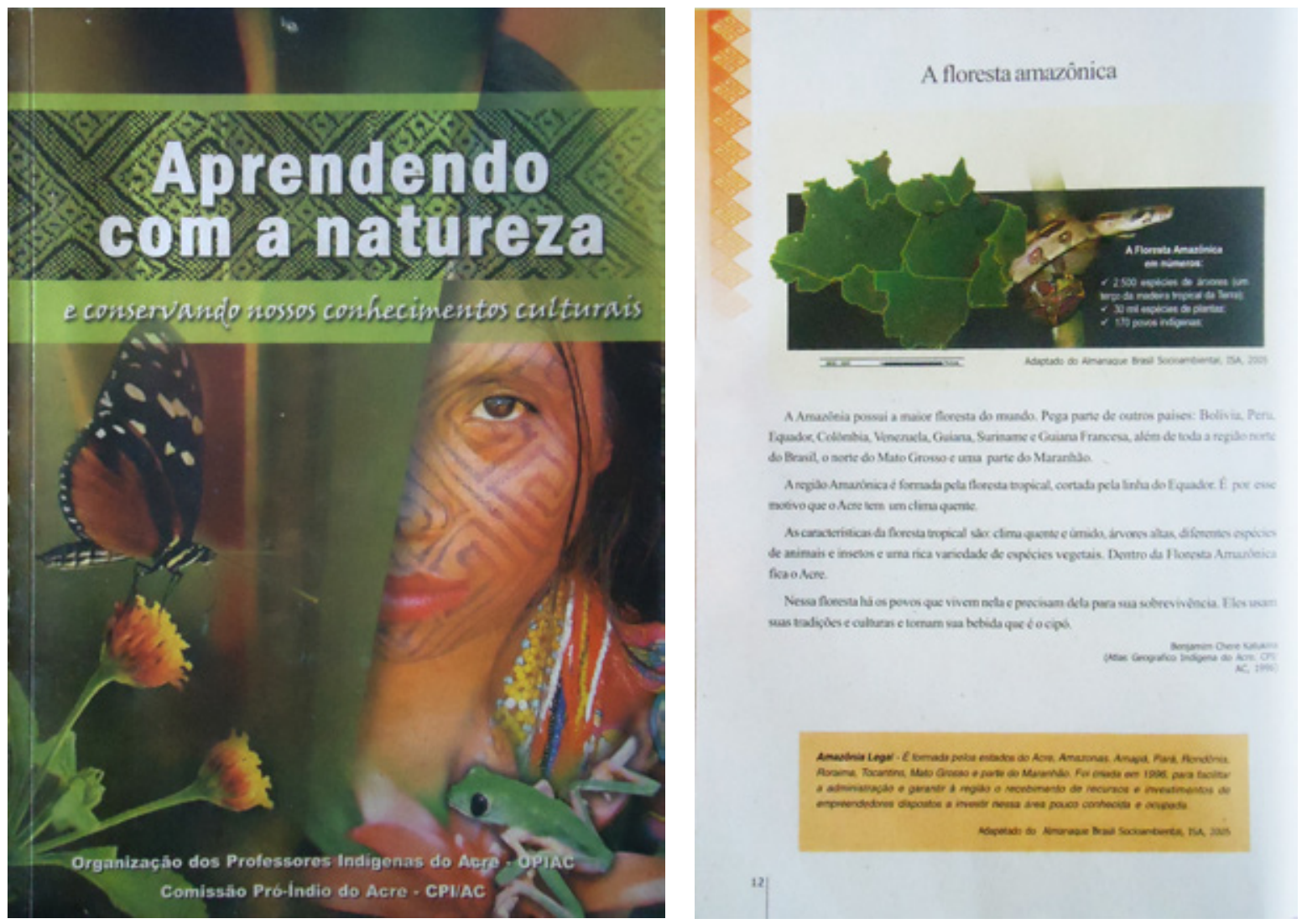

Figuras 112 e 113:

Primeira capa e páginas do miolo de Aprendendo com a Natureza e

Conservando Nossos

Conhecimentos

Culturais (2006). Fonte:

Pesquisa de campo, Paiva (2019)
Noronha e Galvão ressaltam o caráter prescritivo dos direcionamentos repassados pelos coordenadores com quem trabalharam, lastimando a falta de liberdade criativa dentro do desenvolvimento dos projetos.

Se você for ver, mais da metade dos livros que eu fiz para eles, mais da metade têm o mesmo projeto gráfico. Não tem tanta variedade de direcionamento gráfico mesmo.

No começo tinha, por exemplo, aquele Uĩ Bena, se não me engano, o nome, que é os quelônios, que é um quadradinho. Tem diagramação interna. Exatamente, esse aí foi um dos livros que eu mais me orgulho de ter feito, porque eu tive liberdade, esse, na verdade é um problema de muitos clientes, não só da CPI, aí eu acho que é um problema, o cliente que restringe o trabalho do designer. Eu acho que isso daí muitos clientes são assim, não é uma exclusividade da CPI. E a CPI, especialmente no caso dos PGTAs, que foi a maior parte dos livros que eu fiz para eles, eles restringiam bastante o meu trabalho com designer, enfim, o trabalho continua ficando legal, fica bonito, mas você próprio, como designer você percebe que o livro ele não tem muitos recursos de design. (NORONHA, 2019)

Mas quando você tem liberdade, mais liberdade para trabalhar o layout, quando você tem uma plataforma, fica mais interessante. Por exemplo, não daria para fazer isso no papel... como é? Reciclado. Não dá para fazer isso É perder tempo. Isso aqui sai um borrão no papel reciclado. Você entendeu? Então aí sabendo na CPI também que eu tinha. Olha. Esse material eles são muito específicos. Eles não querem mudança. É assim que eles estão acostumados. O padrão é esse. (GALVÃO, 2019) 

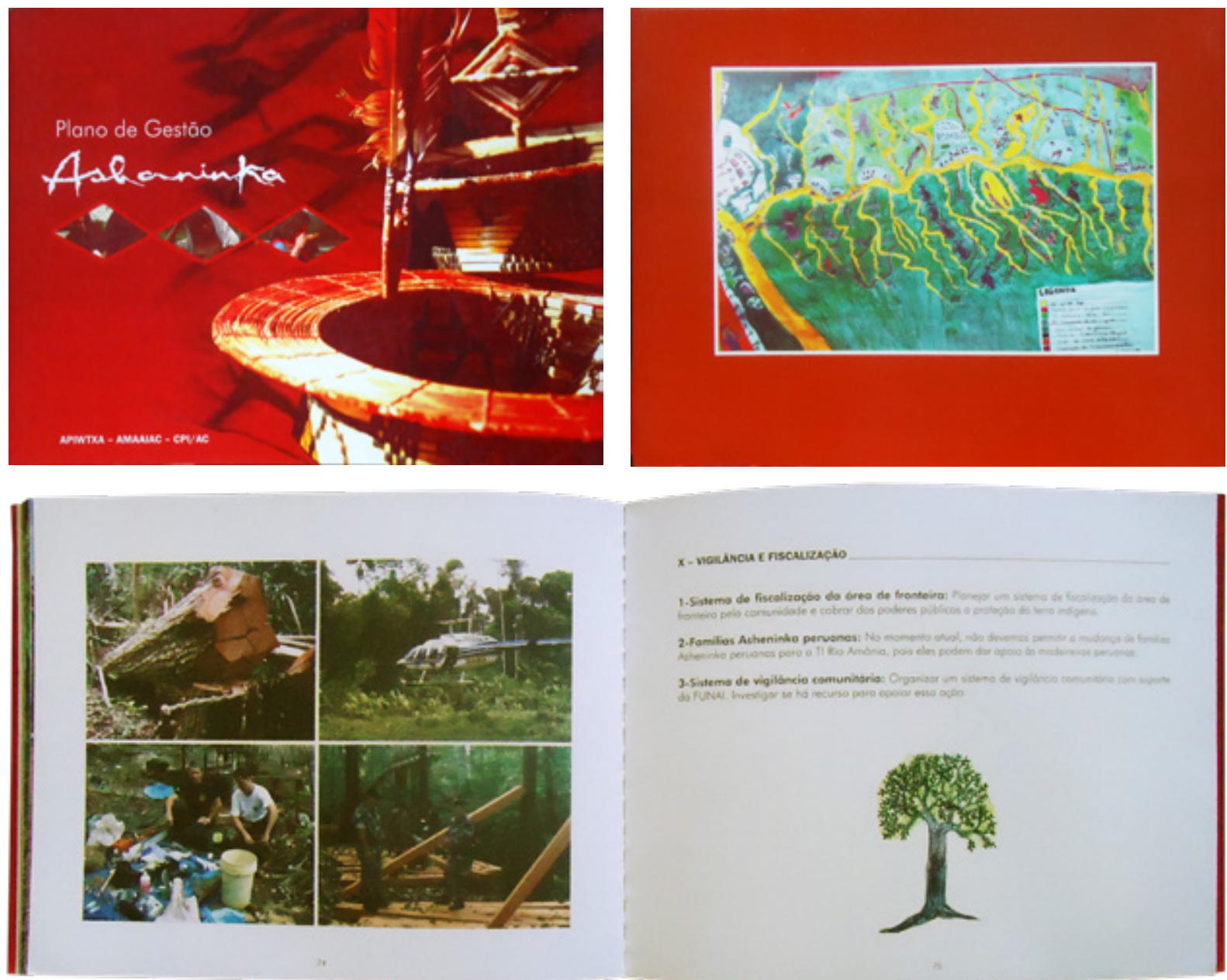

Por outro lado, os designers também reconhecem a complexidade dos processos envolvidos, os vários atores que estão inseridos nos projetos e a importância de valorizar o que é produzido durante as oficinas. Eles são o último elo de um longo encadeamento de procedimentos que fazem parte de um projeto maior e que, fundamentalmente, trata de fornecer àqueles autores e etnias ricos insumos informacionais, de grande importância para a sua dinâmica social e educacional. Há uma cautela especial no que diz respeito às dificuldades encontradas para a compreensão de formas adequadas e interessantes para a representação de conceitos e especificidades culturais das etnias indígenas, com o perigo constante de adentrar o território do estereótipo folclórico, simplificado e colonizador (NORONHA, 2019; GALVÃO, 2019).

A indefinição sobre até que ponto o designer deveria trabalhar sobre os conteúdos textuais e imagens dos livros também existe dentro da equipe da entidade, não sendo uma questão de consenso. Enquanto alguns membros da equipe defendem o mínimo de intervenções possível, ainda se apegando ao modelo simples e mais artesanal dos primeiros materiais produzidos, outros já se posicionam a favor de utilizar o tratamento de imagens e os projetos gráficos de modo a valorizar, modernizar e diversificar os livros produzidos.

Mas isso até hoje é um pouco... discutido, assim, não é uma coisa de consenso. Porque tem uma turma da CPI, dos colaboradores antigos, que já passaram, dos consultores, que acha muito mais legal a gente manter aquele projeto original, precioso, puro, sem intervenção de nada, e tem outra parte que fala "ah não, mas a gente fazendo os projetos gráficos e melhorando as imagens com tratamento, é mais bonito". Embora nesse período,

Figuras 114, $115 \mathrm{e}$ 116: Primeira capa, quarta capa e páginas do miolo do Plano de Gestão Ashaninka (2007). Fonte: Pesquisa de campo, Paiva (2019). 
Figuras 117 e 118: Primeira capa e página do miolo do Nukũ Tsãy

Shawãdawa (2007).

Fonte: Pesquisa de campo, Paiva (2019). dependendo de quem é o artista gráfico, a gente também tem livros que ficaram bem feios (risos). Então ter a entrada do designer gráfico, do projeto gráfico, do artista de impressão, também não garantiu beleza pra um monte deles, e a gente é que sempre puxou pelo bonito. Entendeu? Ele tem que ser o autor indígena expressando o que ele quer, o que ele acredita, o que ele acha que vai ser bom pra ele, melhorar sua sociedade seu povo, mas bonito também. A gente queria muito mostrar a beleza indígena por esses livros, entende. (SENA, 2019)

De todo modo, é inegável que após a virada dos anos 2000, com o barateamento das técnicas de reprodução e composição gráfica, assim como as parcerias com designers variados, os livros da Coleção se diversificaram visualmente e passaram a explorar novas possibilidades visuais. Longe de tentar definir se a abordagem mais artesanal adotada na década de 1990 é melhor ou pior a estes novos direcionamentos, o intuito da discussão aqui proposta é compreender as maneiras pelas quais a aparência gráfica e visual dos livros são um reflexo de intricados contextos econômicos, tecnológicos e culturais, nos quais a CPI-AC e os professores indígenas estão inseridos e pelos quais buscam navegar. A diversidade de abordagens encontradas e adotadas pela instituição, materializadas na pluralidade de livros produzidos, faz com que a Coleção Autoria Indígena seja uma valiosa fonte para o desenvolvimento de análises e para a compreensão dos processos envolvidos na produção de livros feitos por e voltados para populações indígenas.

Os questionamentos enfrentados ao longo da profícua trajetória da Coleção demonstram as muitas possibilidades pelas quais o design - enquanto campo de conhecimento e atividade crítica, consciente de sua capacidade de facilitar a compreensão de projetos complexos e interdisciplinares e da comunicação intercultural - poderia contribuir para a elaboração de métodos para o desenvolvimento de projetos que possam, adequada, eficiente e sen-
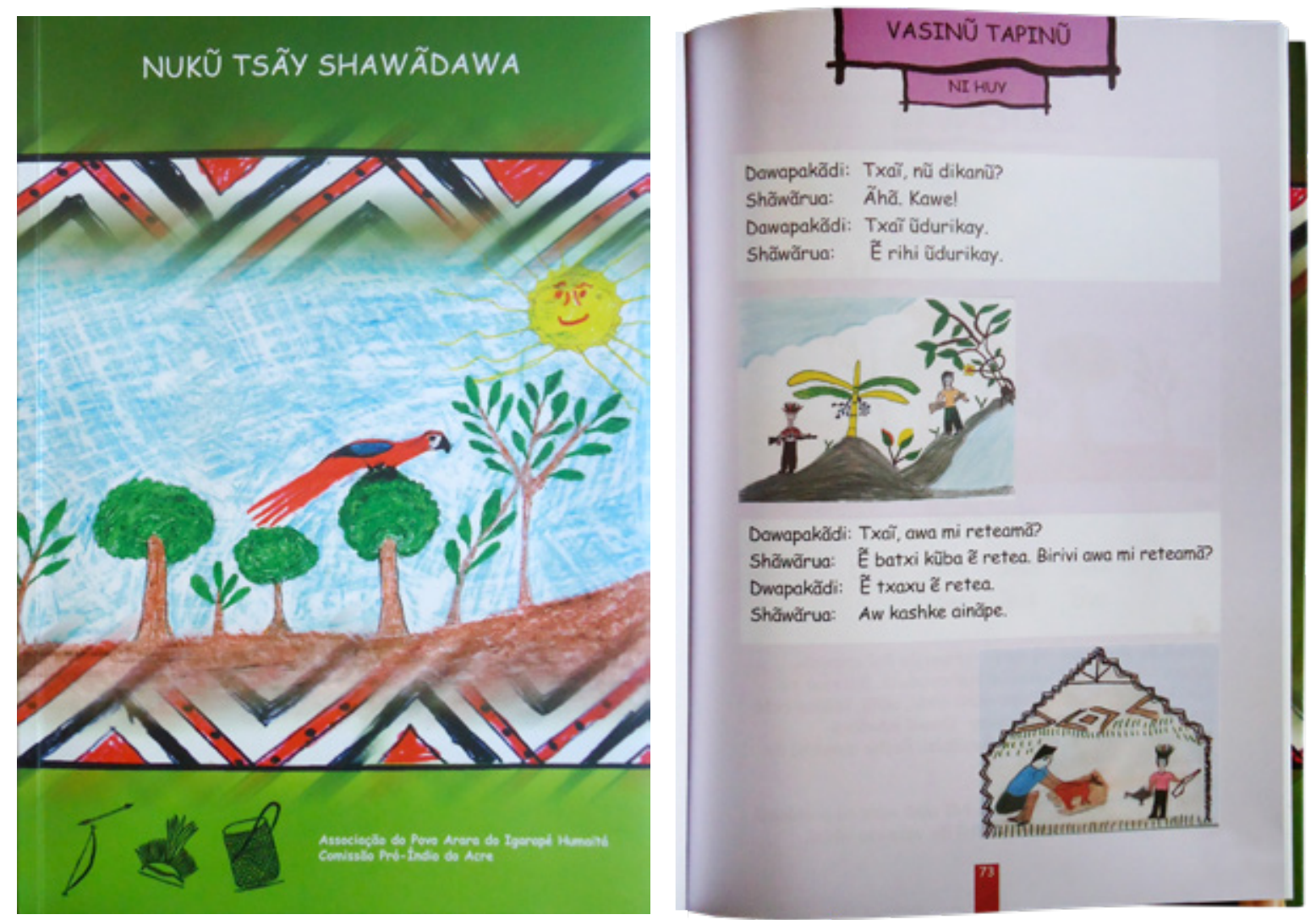
sivelmente enriquecer e valorizar produtos editoriais advindos de culturas ancestrais. Além disso, evidencia uma série de cuidados e posicionamentos a serem tomados para evitar o desrespeito e a descaracterização de elementos criados por autores de etnias distintas e específicas.

\section{4. "O mundo indígena é bem colorido"}

A resposta de Joaquim Tashkã Yawanawa quando questionado sobre o que lhe chama mais atenção no visual dos livros da Coleção Autoria Indígena é um bom ponto de partida para a articulação das principais características gráficas dos livros.

Eu acho que sim, porque o mundo indígena é bem colorido. Você pode ver os livros, são tudo muito coloridos, todos são muito coloridos aqui. É uma característica indígena (...) a pessoa gosta de estar pintada de urucum, de jenipapo, são as cores também que você vê quando toma ayahuasca. São cores também do mundo espiritual também, quando você vê, você entende, verifica, isso tem a ver com o livro... (TASHKÃ YAWANWA, 2019)

Segundo Monte (1996), já no primeiro curso realizado, percebeu-se que os monitores indígenas em formação, ao anotar as matérias compartilhadas em sala, ilustravam, por conta própria, o conteúdo escrito com desenhos e grafismos. Deste primeiro momento, os assessores já passaram a perceber a importância da representação visual dentro do contexto da educação indígena. Dessa percepção se origina a ideia de utilizar as ilustrações nos primeiros livros produzidos.

Com o entendimento de que a ilustração e os grafismos também se configuram enquanto uma forma de escrita e comunicação entre esses povos, nos cursos consecutivos a produção livre (sem direcionamentos formais ou temáticos por parte dos assessores não-indígenas) de ilustrações passou a ser incentivada nos momentos de formação.

A gente sempre pedia um texto e um desenho - porque o desenho também é um texto. Ele também é um peso, como uma coisa escrita, de você olhar e você compreender, então eles trabalhavam sempre com texto e desenho. A gente nunca trabalhou só com o texto. Iniciava, geralmente, com desenho e, depois, passava para o texto.

(...) Então, nunca foi feito um desenho falando "ah faça a onça assim". Não, os desenhos eram livres, a gente sempre deixou muito claro, da própria manifestação deles, do modo que eles queriam. Mas os desenhos estavam representados junto com o texto que estava sendo escrito. Aí, quando vai montar o material didático, também tem essa preocupação. Mesmo na época que se trabalhava com a offset, uma coisa mais simples, de tentar fazer um material bonito. (GAVAZZI, 2019)

A estética propiciada pelos recursos técnicos disponíveis até o final da década de 1990 e pelo direcionamento gráfico dos livros - definido pela equipe da CPI-AC - é certamente uma das características mais marcantes da Coleção. Afinal, de 1983 a cerca de 2001, a grande maioria dos livros produzidos seguiam essa mesma lógica: abundância de ilustrações, raras 
fotografias, cores sólidas e vibrantes em áreas chapadas delimitadas por linhas orgânicas bem definidas. Do total de livros da Coleção, 93\% possuem ilustrações, enquanto apenas cerca de $28 \%$ possuem fotografias.

Mesmo após a virada digital, as ilustrações continuam sendo elementos gráficos preponderantes nos layouts e nos conteúdos dos livros. Porém, a heterogeneidade de sua reprodução, apesar de propiciar uma maior fidelidade aos originais, não permite que haja uma característica indentitária compartilhada entre os livros lançados a partir de 2002.

De toda forma, considera-se que as ilustrações possam ser o principal fator visual que unifica os livros enquanto parte de uma Coleção. Elas também são o único indicador gráfico de que os conteúdos apresentados nos livros derivam de sociedades ágrafas, baseadas na oralidade. As ilustrações, os grafismos específicos de cada etnia e a combinação entre os dois, feitas

Figuras 119, 120

e 121: Primeira capa, quarta capa e páginas do miolo do Uĩ Bena (2006). Fonte: Pesquisa de campo, Paiva (2019) pelos professores indígenas, representam, no layout dos livros, as formas de escrita não verbais que são tradicionais destas culturas.

A título de comparação, em artigo publicado em 2014, os pesquisadores Sérgio Antônio Silva e Paula Cristina Pereira Silva realizam um apanhado sobre o tratamento tipográfico de um conjunto de livros de autoria indígena, em sua maioria publicados pela Universidade Federal de Minas Gerais.
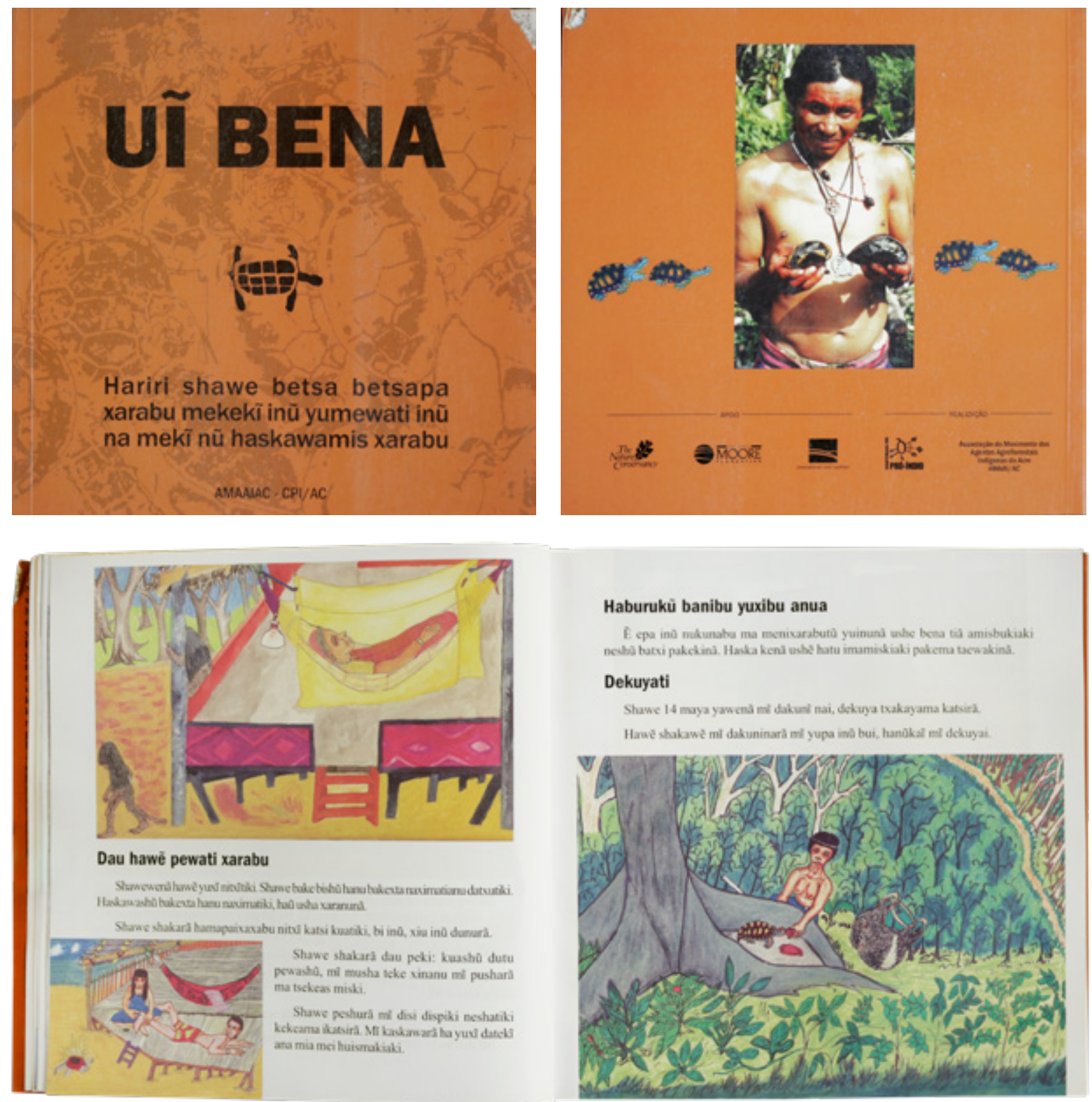


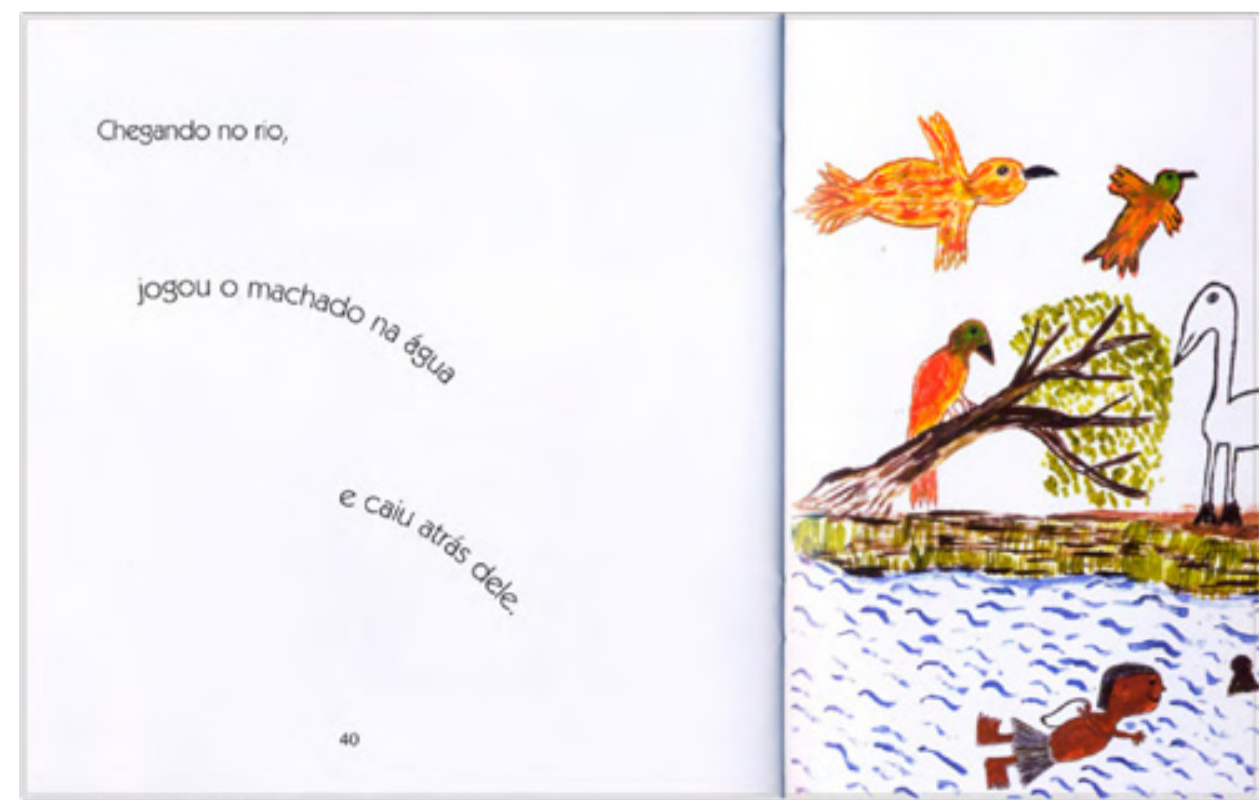

Os autores trazem um questionamento sobre as possibilidades comunicativas do projeto tipográfico dos livros, que envolve tanto o tipo selecionado quanto a sua configuração visual no projeto de composição da página.

Por fim, é importante ressaltar que o designer gráfico também possui a responsabilidade de comunicar visualmente um conceito, uma ideia, uma informação e uma cultura. Na figura 8: O machado e a abelha, de Werimehe e Kanátyo Pataxó, notamos que alguns impressos indígenas foram diagramados com a tipografia tratada como elemento comunicador de uma mensagem visual na página. Vê-se, assim, o chamado texto-imagem, no qual uma informação é voluntariamente transmitida ao leitor antes mesmo que ele inicie a leitura do bloco de texto. (SILVA, SILVA, 2014, s/p.)

Além de complementar a informação verbal textual, esse tipo de tratamento gráfico do bloco de texto remete à expressividade e ao aspecto performático existentes na transmissão oral de conhecimentos, tradicional das etnias indígenas brasileiras. Esse tipo de abordagem - ou abordagens semelhantes - não é encontrada nos livros da Coleção, estando as características da oralidade presentes na própria escrita do texto e na composição do discurso verbal.

No mesmo artigo, é ressaltada a possibilidade de construir relações entre tipografias que possuam um "traço mais manual, irregular e caligráfico" (SILVA, SILVA, 2014, s/p.) e os grafismos indígenas, inclusive, utilizando-os como elementos gráficos nos layouts. Essa abordagem foi frequentemente aplicada nos projetos gráficos da coleção, sendo, inclusive, um dos direcionamentos comuns repassados pela equipe para a composição das capas dos livros de leitura.
Figura 122: "O

machado e a abelha", a "figura 8" referenciada por Silva e Silva (2014). Fonte: SILVA, SILVA (2014, s/p.).
A dimensão semântica (Farias, 2016) dos elementos verbais é percebida especialmente na utilização de letras mecânicas que buscam reproduzir o traço escritural, trazendo maior expressividade às composições. A intenção geral parece ser no sentido de remontar ao fazer manual, assim como ao caráter educativo dos livros, relacionado ao contexto de alfabetização e letramento. Entrevistas com designers que prestaram serviços à 
CPI-AC confirmam que este era um direcionamento comum, repassado durante o processo de configuração dos layouts. (PAIVA, SOUSA, 2019, p. 2125)

Se considerarmos a visualidade do livro enquanto um espaço expositivo, onde práticas, memórias, objetos e representações podem ser resinificadas, preservadas, compartilhadas e debatidas (MONTE, 1996; GRUZYNSKI, 2007), concordamos com Gomes (2014) que, ao analisar iniciativas indígenas em processos museológicos, aponta o processo de antropofagia de "meios, técnicas e processos de representação, cujos resultados são os diversos modos de apropriação e gestão indígena do que é denominado, no mundo ocidental, de patrimônio cultural e memória social” (GOMES, 2014, p.19).

$\mathrm{Na}$ verdade, quando nós começamos a utilizar esse grafismo, foi trabalhando muito essa memória dos próprios professores. Porque, desde o início mesmo, nós sacamos que havia uma necessidade muito grande de pesquisa. De pesquisar não só a história recente, o cativeiro, o índio seringueiro, essa coisa toda que a gente já sabia, mas o que antecedia isso, o que que eles guardavam, ainda, dessa memória. Então foi muito nesse sentido, de levantar essa memória entre eles. (MAIA, 2019)

O impacto causado pelos livros da Coleção nas comunidades indígenas e, em particular, pelas ilustrações, é atestado por Joaquim Tashkã ao narrar que, em visitas às terras indígenas, era comum encontrar páginas dos livros recortadas e coladas nas paredes das casas.

Mas o legal que era bem original, você sentia nos olhos dos professores, eles pegavam as cartilhas era "caramba, olha só, que legal!" eles sentiam muito orgulho disso, de levar os livros para as escolas depois de participar dos cursos da CPI, dos cursos anuais. Isso que era legal, deles pegarem nos produtos. Sentir orgulho do seu próprio trabalho, da motivação, excitação de levar algo que realmente ia contribuir. Eles ficavam tão animados que você chegava nas aldeias, eu acho que eles usavam só a metade, e a metade rasgavam, botavam e colavam nas paredes.

Eu já cheguei a ver muitas vezes na aldeia. Eu vi muito capa de livro, texto de livro, textos mesmo, colados nas casas. Eu falei, para quê, e num dia ia perguntar, fiquei bem indignado. Nós trabalhamos eles rasgam os livros, e, perguntei pro professor: qual é, você está rasgando os livros. "Não, não, nós estamos, colocamos aqui, pra qualquer pessoa poder ver e lê". "Para todo mundo ver o nosso trabalho". Assim tudo bem, tranquilo. Fiquei mais tranquilo. (TASHKÃ YAWANAWA, 2019)

A diversidade dos livros, tanto temática quanto estética e editorial, confirma a rejeição de Graúna pela expressão "livro com cara de índio" (GRAUNA, 2013). A Coleção Autoria Indígena é repleta de publicações que documentam a significativa diversidade de abordagens, representações visuais e literárias propostas pelos autores indígenas, com expressões variadas e cambiantes, que podem nos fornecer um panorama gráfico e literário da construção de uma memória coletiva que parte de novos processos de afirmação identitária. 

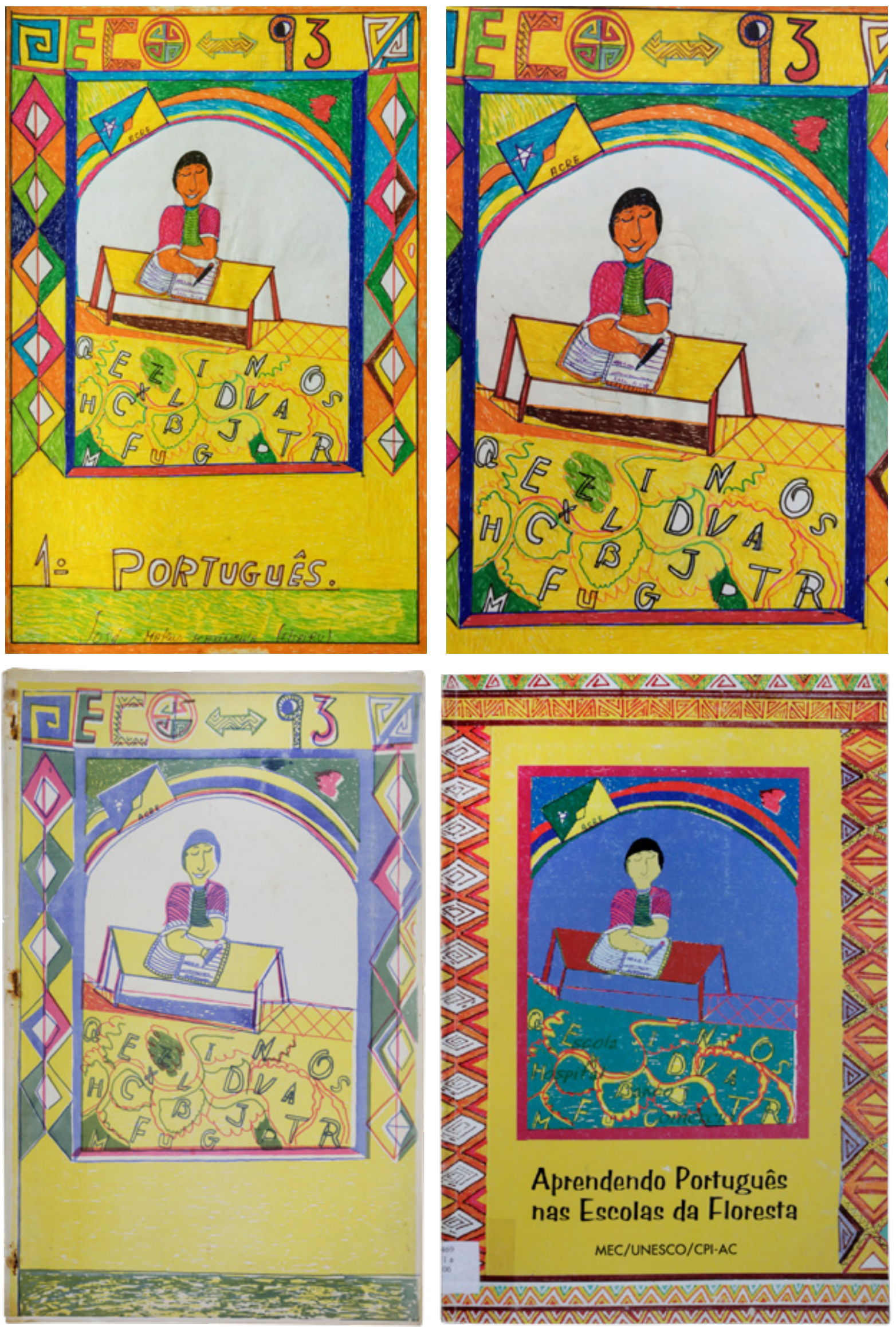

Figuras 123, 124, 125 e 126: De cima para baixo da esquerda para a direita: llustração original utilizada para a capa de Aprendendo Português nas Escolas da Floresta ( $1^{\circ}$ e $2^{\circ}$ edições, 1993 e 1997, repectivamente); detalhe da ilustração, primeira capa da primeira (1993) e da segunda (1997) edição de Aprendendo Português nas Escolas da Floresta. Fonte: Pesquisa de campo, Paiva (2019). 



\section{Os livros kaxinawá da Coleção Autoria Indígena}

O capítulo final desta dissertação explora as relações entre os principais elementos que compõem os projetos gráficos dos livros de autoria kaxinawá e as suas relações com as manifestações culturais e visuais tradicionais dessa etnia.

Para tanto, parte-se de um apanhado geral a respeito da cosmologia estética (LAGROU, 2007) Kaxinawá, para, em seguida, examinar os livros da Coleção Autoria Indígena escritos, coletiva ou individualmente, por autores da etnia em questão. Intentou-se realizar um levantamento dessas publicações, assim como de seus autores e dos principais temas abordados.

Os principais elementos gráficos compositivos do projeto de design editorial são mapeados de acordo com as categorias propostas por Twyman (1979). Atenção especial é dada aos elementos pictóricos (Ibid.), no caso, às ilustrações, analisadas a partir do método proposto por Goldsmith (1980).

\subsection{Cultura material e imaterial Kaxinawá}

Em artigo publicado em 2010, a antropóloga Marcela Stockler Coelho de Souza faz um interessante apanhado a respeito das várias facetas manifestadas pelas culturas das etnias indígenas brasileiras. Segundo a autora, a constituição das identidades culturais dos povos autóctones se desenvolve através de uma série de tensões, movimentando-se entre o visível e o invisível, entre o material e o imaterial, entre o coletivo e o individual, entre a identidade e a alteridade (SOUZA, 2010).

Essas tensões são reveladas e escondidas não só de acordo com o que se pode, literalmente, observar, como seria esperado. Complexas e intrínsecas às cosmologias próprias, advindas de formas específicas de entender o mundo (e aqui, novamente, tem-se o mundo visível e o invisível), elas se mostram, ou não, tanto de acordo com aquilo que é visível, quanto de acordo com o que não é. Além disso, dependem de quem as observa, e tudo o que pode ou não ser enxergado pelo observador em questão (Ibid.).

Os grafismos e desenhos produzidos por diversas etnias brasileiras constituem-se como um dos melhores veículos de representação (ou, quando aplicados sobre cerâmicas e outros artefatos, materialização) dos variados processos de "revelações e ocultamentos" (SOUZA, 2010, p. 164), pois oferecem uma dimensão visível a relações sociais e conhecimentos cujo grau de percepção é definido de acordo com o observador (Ibid.).

Com isto em mente, pode-se iniciar a tentativa de revelar algumas das concepções, princípios e sentidos trazidos à tona pelas manifestações visuais kaxinawá, sabendo-se, de princípio, que tal tentativa é capaz de acessar apenas uma fração semântica de seu real significado.

A oposição entre visível e invisível (material e imaterial, identidade e alteridade, revelar e ocultar...) é uma forma interessante de iniciar a discussão sobre os Kaxinawá pois o dualismo é uma significativa característica de sua expressão estética, assim como de sua organização social e identidade cultural, de modo geral (LAGROU, 2007). 
Figura 127: Criações em miçanga e manta de algodão kaxinawás expostos na sede da CPI-AC. Fonte: Pesquisa de campo, Paiva (2019).

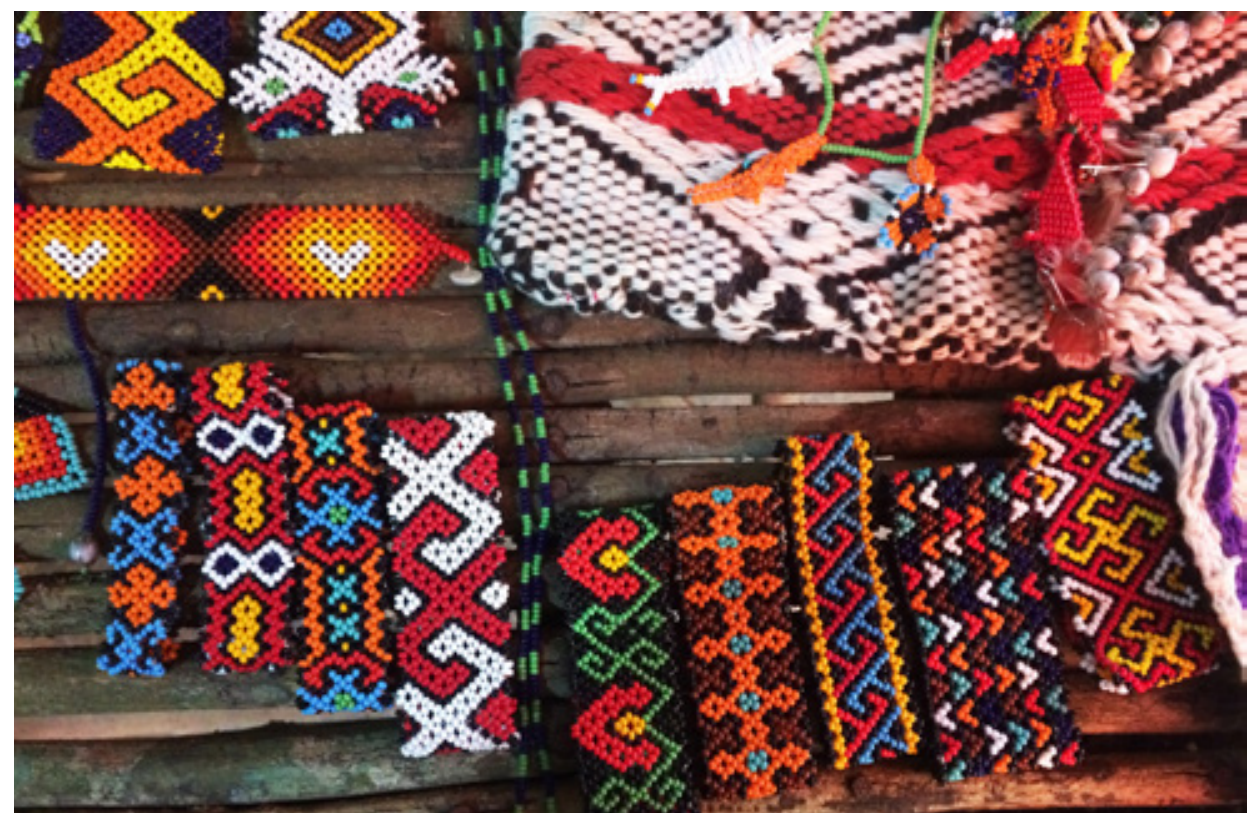

Para os Kaxinawá, o mundo visível, composto pelas manifestações corpóreas materiais, possui, também, uma faceta invisível: a yunxidade. Esse conceito, segundo Lagrou (1991, p. 28), sintetiza bem a "cosmovisão xamânica" dessa etnia, que considera o espiritual, yuxin, como algo que faz parte da natureza e das coisas vivas (em oposição ao "sobrenatural" ou "sobre-humano").

Na vida diária vemos um lado da realidade, onde este parentesco universal das coisas vivas não se revela: vemos corpos e sua utilidade imediata. Em estados alterados de consciência (EAC) porém, o homem se defronta com o outro lado da realidade, onde a espiritualidade que habita certas plantas ou animais se revela como $y u-$ xin, huni kuĩ, gente nossa. Por se manifestar tanto como força vital quanto como alma ou espírito com vontade e personalidade próprias, nenhum termo capta bem este caráter efêmero e polivalente do yuxin. (LAGROU, 1991, p. 28, grifos no original)

Dessa forma, yuxin é traduzido às vezes como "alma", às vezes como "espírito", e às vezes como "encantado", estando relacionado a uma energia, um aspecto espiritual. A realidade possui um "lado yuxin", que é mediado pelos xamãs (Ibid., p. 29, grifos no original): "para os Kaxinawá a pessoa é uma combinação de (vários) yuxin com a carne, o corpo. O resto dos fenômenos animados é composto pelos mesmos elementos: corpo e yuxin. Os animais têm um lado corporal e um lado yuxin, assim como as plantas".

Além de animais e plantas, o reino dos fenômenos animados ainda conta com seres chamados yuxin. A qualidade corporal destes seres, que povoam o ar, a floresta e as águas, é essencialmente ambígua, transformável de um corpo em outro. É nesta fugacidade física que se mostra o poder dos yuxin. Eles podem aparecer "como gente, huni kuĩ mesmo", assim como na forma de certos animais. (LAGROU, 1991, p. 29, grifos no original)

Nas narrativas tradicionais Kaxinawá que explicam a origem de seus "bens culturais" mais significativos (por exemplo, o fogo, o tabaco, a tecelagem, o desenho, o plantio), via de regra a conquista ou apoderamento de 
tal bem é fornecida ou facilitada por um yuxin que assume a forma de um animal ou de uma pessoa (Ibid., grifos no original): "Desta maneira viveram durante algum tempo entre os homens, sob forma humana, a rata parteira (xuya), a aranha tecelã (Baxnem pudu) e outros".

Uma variedade de substâncias naturais permite aos seres humanos aproximar-se (enxergar e comunicar-se), ou proteger-se dos yuxin, assim como a emissão de alguns sons e aromas podem atraí-los ou espantá-los. O sabor de determinados animais, insetos e vegetais também podem determinar a yunxidade de quem os consome - algumas coisas são "comida de yuxin", possuindo gosto desagradável para humanos, mas consumidas por aqueles que estão sob o efeito dos yuxin (LAGROU, 1991, p. 37). Recém-nascidos, por exemplo, são vulneráveis aos yuxin, podendo "perder-se" no "mundo espiritual", do qual ainda não possuem a habilidade de retornar. Outros exemplos de vulnerabilidade são apresentados por Lagrou (1991, 2010), tendo em vista que yuxin podem causar mazelas (doenças, feitiços), assim como benefícios.

Releva-se, nesse resumido apanhado, as várias oposições e paralelos essencialmente envolvidos na complexa e dúbia compreensão cosmológica dos Kaxinawá. Yuxin navegam entre o material e o imaterial, entre o visível e o invisível, podem ser humanos ou animais, e, ao mesmo tempo que existem separadamente, fazem parte de ambos. Outros dualismos, de ordem mais prática, também são fundamentais da vida cotidiana e social kaxinawá.

A divisão entre os sexos é elementar na organização social Kaxinawá, constituindo-se como a maior marca de sua vida cotidiana (em comparação com outros tipos de divisões, como a etária, por exemplo). As atividades são, em sua maior parte, divididas entre os grupos de mulheres e homens que constituem a comunidade, e as crianças são inseridas nessa dinâmica desde muito cedo (Idem, 1991).

A segmentação de tarefas entre homens e mulheres inclui as tarefas diárias, tais como os cuidados com a casa, a preparação de alimentos em geral, a lavagem de roupas, a colheita -realizadas pelas mulheres; e a caça, pesca, o plantio da maioria dos vegetais e a produção de borracha - realizados pelos homens (LAGROU, 1991; AQUINO, IGLESIAS, 1994). Algumas tarefas são feitas em conjunto, como o preparo do roçado (a "brocada", quando a vegetação nativa é derrubada e queimada pelos homens, enquanto as mulheres entoam cantos para potencializar o processo), a coleta de determinadas frutas silvestres, o plantio de amendoim, entre outras (LAGROU, 1991).

A produção de artefatos tradicionais, tais como os tecidos de algodão (e seus derivados: redes, lençóis, pulseiras etc), cestas e cerâmicas, também é, de forma geral, parte do domínio feminino (LAGROU, 1991; AQUINO, IGLESIAS, 1994). Lagrou (1991) aponta a existência da prática em cestaria desenvolvida pelos homens, que possui especificidades e é diferenciada daquela feita pelas mulheres ${ }^{1}$.

Segundo Aquino e Iglesias (1994), aos homens também são reservados os papeis de representação e lideranças comunitárias, nas cooperativas de produção de borracha, durante as décadas de 1980 e 1990, e, posteriormente, nas associações. Além disso, os professores e agentes de saúde também são, em grande maioria, homens.

1 Por exemplo, cestos feitos por homens utilizam a palha silvestre, extraída da mata, enquanto cestos feitos por mulheres são feitos com palha plantada. Os cestos de produção masculina são mais utilizados para funções externas, enquanto os de produção feminina são utilizados no ambiente doméstico. As mulheres utilizam as cestas feitas pelos homens no transporte da colheita, mas homens não utilizam cestos produzidos por mulheres para armazenar objetos pessoais (LAGROU, 1991). 
Atualmente, as mulheres kaxinawá vem se organizando e ganhando destaque, especialmente através da produção de artefatos. Possuem uma associação própria, a APAMINKTAJ (Associação das Produtoras de Artesanato das Mulheres Indígenas Kaxinawá de Tarauacá e Jordão), sediada no município de Tarauacá, e que reúne cerca de 500 artesãs. Sua produção é vendida na capital Rio Branco e em outras cidades do país. Em 2013, a associação foi selecionada para fazer parte da exposição Mulher Artesã Brasileira, realizada na sede da ONU (Organização das Nações Unidas) em Nova Iorque. Dentre os representantes de 12 estados brasileiros selecionados pela curadoria da exposição, a APAMINKTAJ é a única representante do artesanato indígena do país (FULGÊNCIO, 2013). Os principais produtos feitos pelas artesãs são adereços em miçanga (pulseiras, colares, anéis etc) a produtos advindos da tecelagem.

\begin{abstract}
"Trabalhamos com a tecelagem desde a matéria-prima, desde o cultivo. Nós fazemos nosso próprio roçado, plantamos o nosso algodão, fabricamos a nossa própria linha e fazemos diversas peças de tecelagem, desde redes, mantas, lençóis, roupas, assessórios como tiaras, bolsas, tapetes e brincos", explica Raimunda. (FULGÊNCIO, 2013, s/p.)
\end{abstract}

Conforme evidenciado pela presidente da associação, Raimunda Mawapey Kaxinawá, as mulheres são responsáveis por todas as etapas relativas à produção do algodão: o plantio, a colheita e "processos de secar ao sol, abrir, bater, fiar e tingir" (LAGROU, 1991, p. 62). O tingimento é feito com corantes naturais produzidos a partir de plantas, argila, sementes etc, e Lagrou (Ibid.) registra as cores: vermelho, violeta-rosa, violeta, laranja, laranja-amarelo, amarelo, azul, azul escuro e preto. A cadeia de procedimentos é feita em conjunto pelas mulheres de uma comunidade. $O$ fio do algodão que resulta desse trabalhoso processo é utilizado na produção dos tecidos, através da utilização de teares.

A tecelagem é, hoje em dia, a principal fonte de orgulho para os Kaxinawá. A relação do desenho com o suporte aqui é outra. A superfície é plana e não existe antes do desenho; o pano, fundo para a figura, é feito simultaneamente com o desenho. $O$ problema aqui é de, sem modelo à mão, não perder de vista o motivo no meio dos fios da trama. (LAGROU, 1991, p. 137)

Tradicionalmente, apesar de ter contato com todas as etapas do processo durante a infância e a adolescência, a mulher kaxinawá começava a tecer depois de casar-se. Seu marido, além de construir o tear, era também responsável por caçar uma jibóia ${ }^{2}$, cujo couro deveria retirar e esconder atrás do tear, de forma que apenas sua esposa pudesse ver. Atualmente, contudo, "qualquer tempo é tempo de aprender kene" (MURU et al., 2006³, p. 12) O status de "mestra do kene" era, "no tempo dos antigos", atribuído àquelas mulheres que dominavam todo o conhecimento do kene: "histórias, rituais, cantigas e padrões". Hoje em dia, consideram-se mestras as mulheres que "tem conhecimento do maior número de padrões geométricos do kene

2 As relações entre a jibóia e os kene que ilustram as tecelagens kaxinawá são exploradas em maiores detalhes mais adiante.

3 A arte do Kene, provavelmente publicado em 2006, embora não conste a data na publicação (não há ficha catalográfica).

4 Kene é o nome que se dá aos motivos geométricos produzidos pelos Kaxinawá. Tratar-se-á dos mesmos em detalhes mais adiante, no tópico 4.2 deste capítulo. 

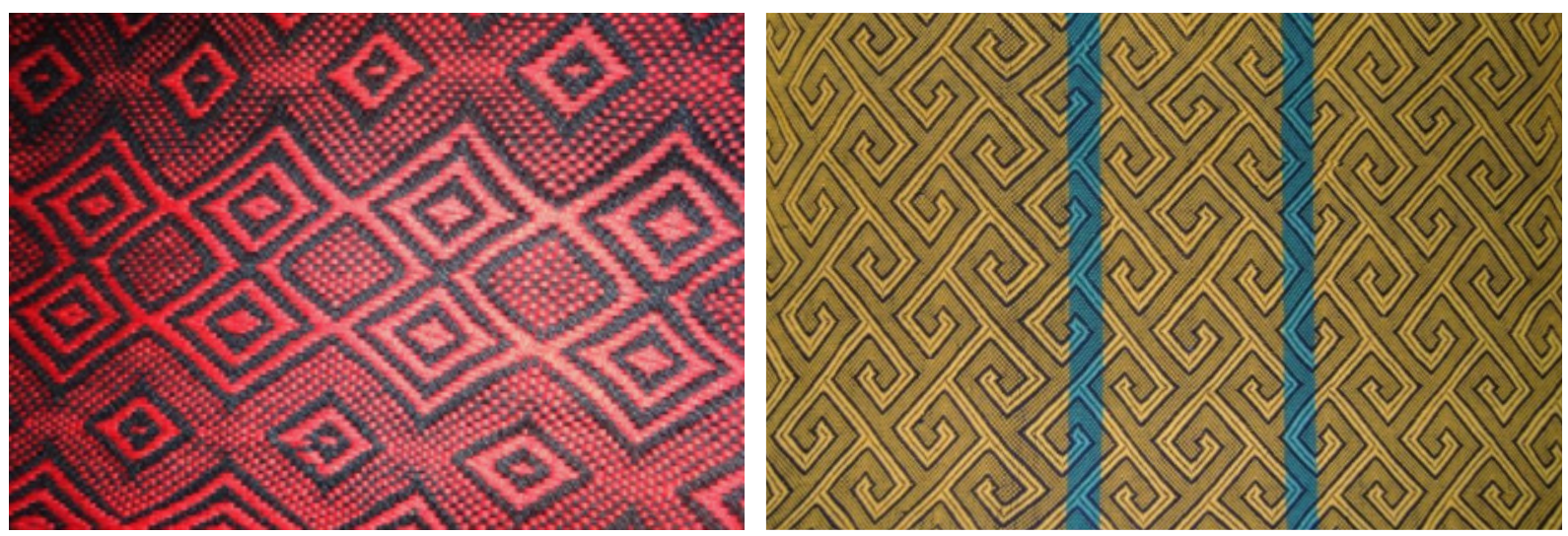

e domina bem a técnica tradicional, seja na tecelagem em algodão, palha, pintura em cerâmica ou, ainda, na pintura corporal" (Ibid.). As mulheres consideradas mestres e que possuem grande domínio sobre a tecelagem são muito respeitadas e prestigiadas dentro das comunidades (LAGROU, 1991).

A comercialização dos tecidos, em forma de mantas, redes, bolsas e adereços em geral (puseiras, cintos, faixas de cabelo etc) é uma importante fonte de renda para as comunidades Kaxinawá. Segundo Lagrou (1991) durante a realização de sua pesquisa de campo em Canoa Quebrada e Moema (aldeias da TI Alto Rio Purus), a venda dos produtos tecidos pelas artesãs era a principal fonte de arrecadação financeira para ambas comunidades. Já segundo Aquino e Iglesias (1994), a produção de borracha configurava-se como o principal produto das comunidades do Alto Jordão, entre 1992 e 1994, quando a pesquisa foi realizada.

Aquino e Iglesias (1994, p. 57) apenas citam que a produção de cerâmicas é uma atividade feminina, sem maiores elaborações, enquanto Lagrou (1991, p. 66) afirma que "há uns vinte anos, a cerâmica ainda fazia parte das tarefas frequentes da mulher e do aprendizado da menina. Agora as panelas de barro foram substituídas por panelas de alumínio". Por outro lado, outros artefatos ainda são produzidos em cerâmica, conforme registrado por Muru, (MURU et al., s/ d., pgs 19 e 33) e Kaxinawá e Iglesias (2010, p. 81):

As mulheres índias tiram "mapu" (barro) debaixo da terra para fazer uma boa cerâmica e fabricar pote, tibungo $^{5}$, tigela, prato e o fuso ${ }^{6}$ para a tecelagem. $O$ barro fica no lugar próximo à água: na beira do igapó, no sangradouro dos lagos.

Há uma ciência que toda mulher índia conhece. Quando vão buscar o barro, as mulheres precisam sair bem cedo. Quando as mulheres chegam no lugar onde está o barro, pedem a força da jibóia para não quebrar seu material que está sendo fabricado.

Além da tecelagem e da cestaria, a produção artesanal tradicionalmente Kaxinawá também abrange a arte plumária, muito embora esta seja uma manifestação que, segundo Lagrou (1991, p.142), já não é encontrada com a mesma característica "majestosa" observada em peças mais antigas (datadas até a década de 1960) preservadas em museus. Segundo a pesquisado$\mathrm{ra}$, isso se deve à constatação de que os ritos que envolviam esta produção específica caíram em desuso devido, em parte, à repressão religiosa sofrida

5 Vaso grande utilizado para armazenar água potável.

6 Ferramenta utilizada para fiar o algodão. 
Figura 130: Cestaria

kaxinawá. Fonte: LIMA KAXINAWÁ (2014)

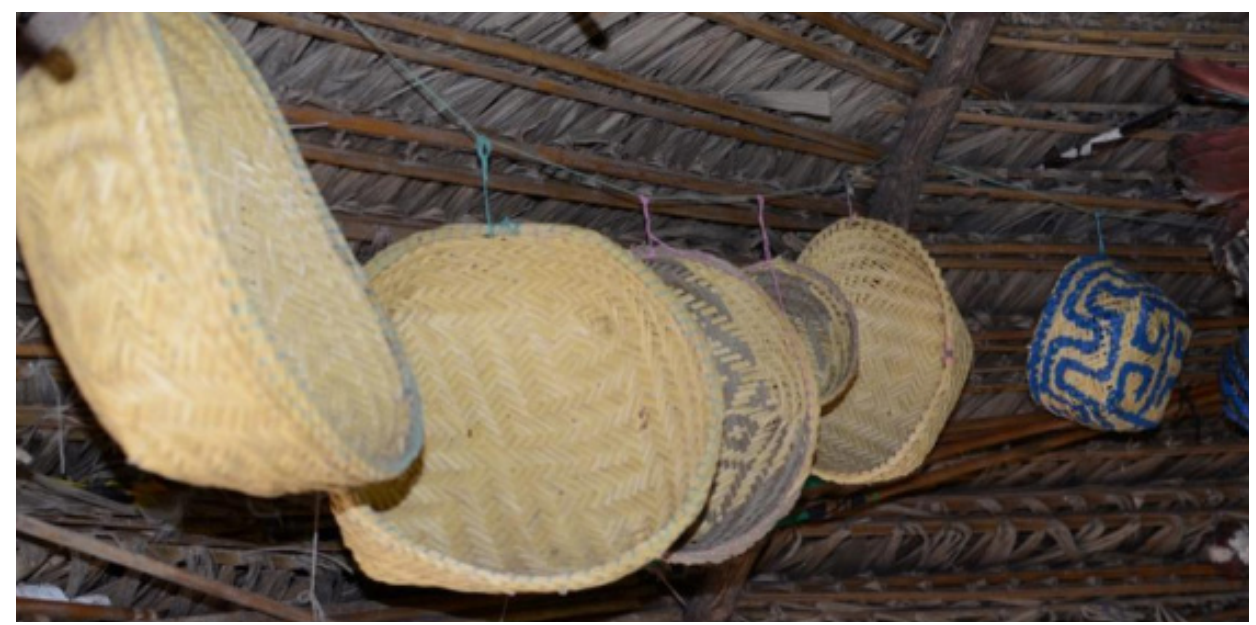

pela etnia e, também, à separação das famílias maiores nas colocações dos seringais (Ibid., p. 143). De todo modo, ainda são produzidos cocares, tais como o pei miti, "cocar de pena da asa", descrito pela pesquisadora. $\mathrm{Na}$ arte plumária, valoriza-se a combinação de cores e a harmonia das composições.

O leque é azul e quatro daư são pendurados no anel: são feitos de roletes de cana envoltos em linha azul, alternada com vermelho e branco, com pequenas penas vermelhas na ponta. Uma faixa de tecido é costurada ao redor de dois terços do anel, onde estão colocadas as penas; o restante é envolto com linha colorida (sempre as mesmas três cores básicas: branco, vermelho, azul). $\mathrm{O}$ cocar com tecido, feito por mulheres, é chamado keneya, com desenho. Entre o tecido e o leque, foi colocada uma faixa de penas do corpo de pássaros pequenos em cores contrastantes. Outro exemplo, onde o leque é amarelo e tem duas faixas de borda; a externa é preta (amarelo e preto é, também no uma combinação kuin), a interna vermelha alternada com azul. (LAGROU, 1991, p. 148)

A arte kaxinawá, de modo geral, valoriza a homogeneidade de composições, fazendo uso de repetições de padrões e de cores. Tal homogeneidade é uma ferramenta para que os elementos que destoam do restante da composição possam destacar-se. Dessa forma, é comum a inserção de pontos ou elementos disruptivos nas composições. Esses elementos valorizam a homogeneidade, ao mesmo tempo que são valorizadas pela mesma. Esta é uma das formas de sensibilização do olhar na arte kaxinawá (LAGROU, 1991).

Lagrou $(1991,2007)$ trata, detalhadamente, da produção de bancos (kenan) esculpidos em madeira (geralmente a partir da raiz da samaúma), decorados com kene pintados, como parte do nixpupima. O nome refere-se à "comer nixpu", planta que enegrece os dentes e que é ingerida pelas crianças durante a cerimônia. O nixpupima é o rito de passagem da infância, condição passiva e dependente de cuidados, para a adolescência, quando o indivíduo já passou pelo período de aprendizagem de habilidades sociais e linguísticas, e já "tem seus próprios pensamentos" (LAGROU, 2007, p. 439).

Os kaxinawá possuem um complexo sistema de atribuição de nomes, que se relaciona diretamente a sua organização social, baseada na divisão ente duas metades. Quando os bebês nascem, eles automaticamente já pertencem a uma metade ou à outra. Cada uma dessas metades se divide novamente em duas seções, que se alternam entre gerações (AQUINO, IGLESIAS, 2010).

7 Enfeite feito com palha. A mesma palavra pode significar "remédio" (LAGROU, 1991). 

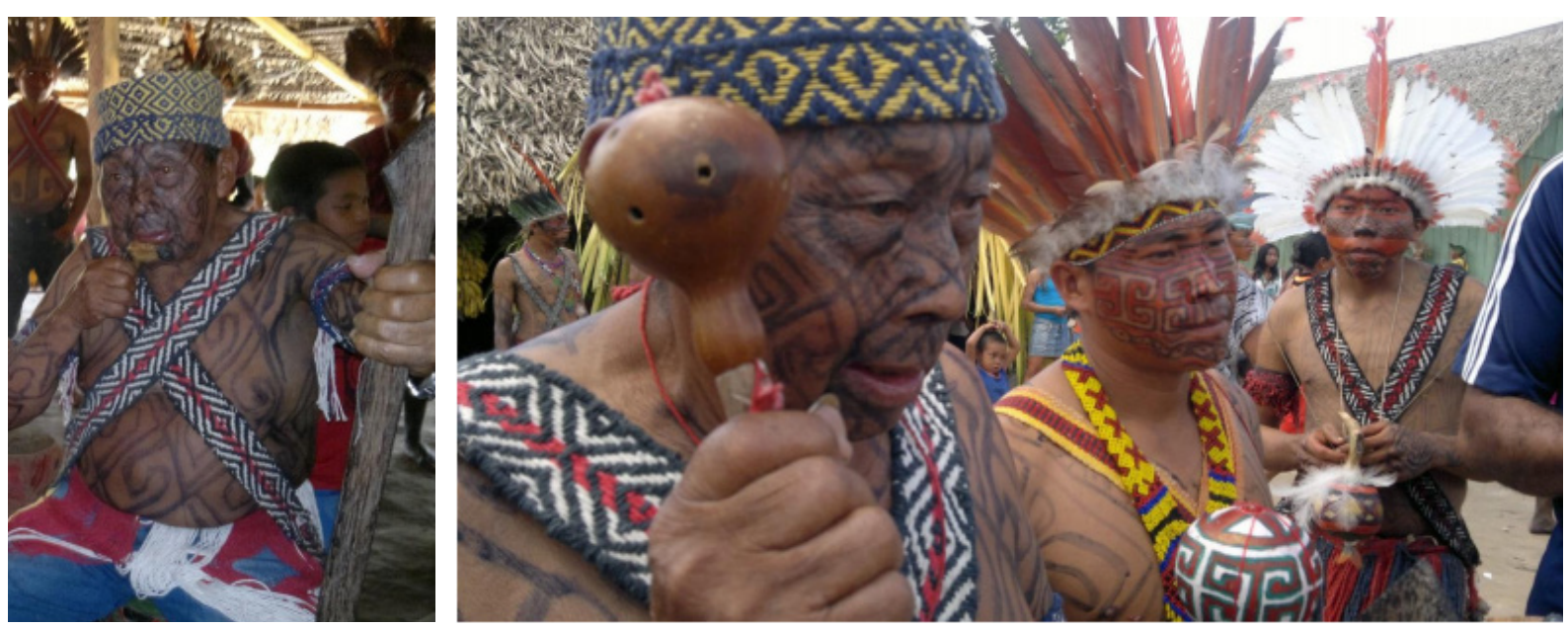

A metade e a seção a que uma pessoa pertence é que determinam com quem ela irá se casar, o papel que terá nas cerimônias e outras atividades. Um homem não deve se casar com mulheres de sua própria metade, somente com as da metade oposta, e idealmente da seção correspondente à sua. Todas as mulheres de sua própria metade são como irmãs, enquanto as da outra metade são esposas em potencial. Do mesmo modo, os homens da mesma metade são como irmãos e os da outra metade são cunhados potenciais, chamados de txai. (Ibid., pág. 147)

O nome que a criança recebe ao nascer faz parte de um repertório fixo e seguirá uma regra de "reciclagem de nomes", de acordo com a alternagem das seções geracionais. Ou seja, uma primogênita pode receber o nome de sua avó materna, enquanto suas irmãs podem receber o nome das tias-avós maternas. Durante a infância a criança deve aprender as relações que possui com outros familiares e membros de sua comunidade, definidas por seu nome, por exemplo, quem é txai (primo cruzado), quem é txaita (esposo potencial) etc. No momento do nixpupima a criança já deve ser capaz de dominar tais conhecimentos a respeito de seu posicionamento neste complexo sistema. $O$ rito de passagem é, também, o batismo, quando as crianças kaxinawá que já perderam todos os dentes de leite tem seus nomes "fixados". Enquanto na infância o nome da criança é utilizado com frequência para referir-se a ela, depois do nixpupima esse nome passa a fazer parte de modo tão íntimo da pessoa (é incorporado por ela), que apenas "amantes e parceiros em contexto privado" o utilizam - chamar um adulto por seu nome próprio é um motivo de vergonha que pode ser comparado à exposição pública das genitais de alguém (LAGROU, 2010, p. 441).

Conforme se pode perceber através da compreensão, ainda que superficial, das relações sociais tradicionais, onde a concepção do indivíduo se dá mediante suas relações com os outros membros de sua comunidade, a noção de identidade para os Kaxinawá é construída "a partir de processos complexos de mimese e alteridade, em constante processo de se fazer a partir do desfazer e refazer o outro dentro de si" (Ibid., p. 20). Essa fluidez ${ }^{8}$ identitária advém de sua concepção cosmológica do mundo e se reflete nas manifestações visuais tradicionais, das quais a mais significativa são os intrincados sistemas de padrões geométricos: os kene.

8 Lagrou (2010) utiliza o termo para referir-se às muitas transformações, transições e renovações que fazem parte da cosmologia e da arte kaxinawá, inclusive no título de seu livro: A Fluidez da Forma.
Figuras 131 e 132 : Pintura corporal e adereços kaxinawá. Fonte: LIMA KAXINAWÁ (2014). 

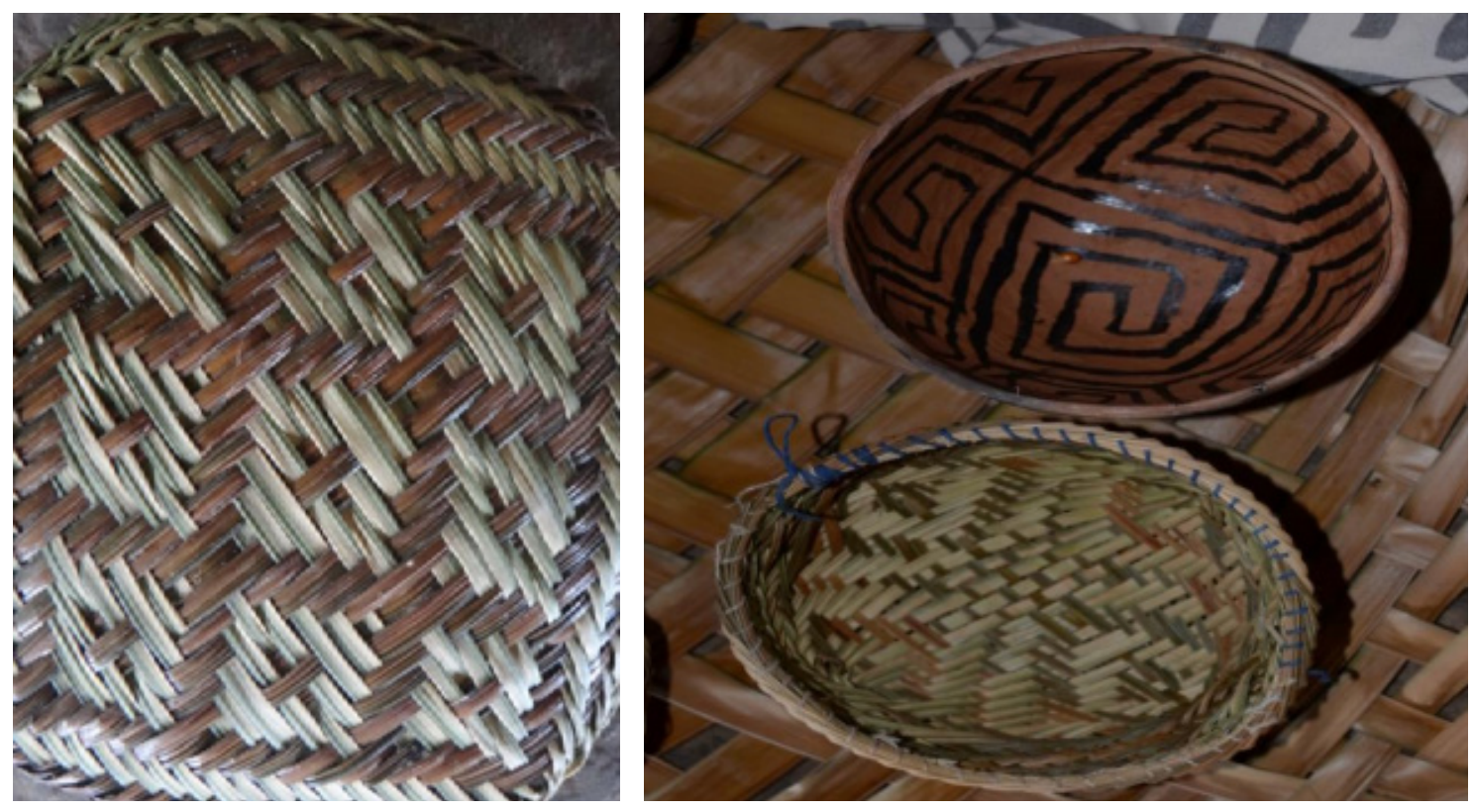

Figuras 133 e 134: Cestaria e cerâmica kaxinawá, ornamentadas com diferentes tipos de kene. Fonte: LIMA KAXINAWÁ (2014)

\subsection{Kene Kuĩ: o desenho verdadeiro}

Os yuxin são seres espirituais fluidos que possuem a capacidade de transformar-se e podem exercer influências diversas (positivas ou negativas), sobre os humanos, seres de corpo sólido, fixados em uma materialidade definida. Essa fixação resulta de uma série de rituais (por exemplo, o nixpupima) que se utilizam de substâncias, artefatos e marcações (por exemplo, a pintura corporal) realizadas com tal objetivo de "fabricação da forma sólida" (LAGROU, 2010, p. 59). A "tensa relação" entre tal fabricação e o "poder das imagens livres e flutuantes" é a base da fenomenologia kaxinawá, e a chave para compreender suas manifestações artísticas.

Estas imagens [livres e flutuantes] se manifestam em três tipo de formas diferentes: na forma de espíritos ou seus donos (yuxin e yuxibu ${ }^{9}$ ), na forma de transformações em imagens e visões (chamadas dami, estas são 'suas mentiras') e, finalmente na forma de caminhos esboçados em desenhos (kene). Estes padrões de desenhos são chamados de "a língua dos yuxin", e podem ser produzidos somente pelas mulheres. Este grafismo é chamado de a arte de escrever a coisa verdadeira: kene kuĩ. Escrever na linguagem do alfabeto é chamado de nawan kene, a escrita dos estrangeiros, no caso, a dos brancos. Todas estas imagens, as desenhadas ou as tecidas para serem contempladas e outras para serem invocadas em cantos, influenciam ativamente e agem sobre as formas assumidas pela vida no mundo kaxinawá. (LAGROU, 2007, p. 59)

Duas narrativas fundamentais ${ }^{10}$ auxiliam a compreensão do kene e de seus significados para os Kaxinawá. A primeira conta a história de um kaxinawá que, durante uma tocaia para caça, é seduzido por uma mulher-

9 "Os yuxibu são o plural ou o superlativo dos yuxin, espírito ou alma, possuem capacidade de agência e ponto de vista, intencionalidade. Estes seres yuxibu não são limitados pela forma, podem se transformar à vontade e podem transformar a forma do mundo a sua volta" (LAGROU, 2010, p. 59).

10 Há diversas versões destas narrativas, os resumos apresentados aqui foram feitos com base naquelas apresentadas por Ibã (2006), Muru (In MAIA, 1999) e Lagrou (1991). 


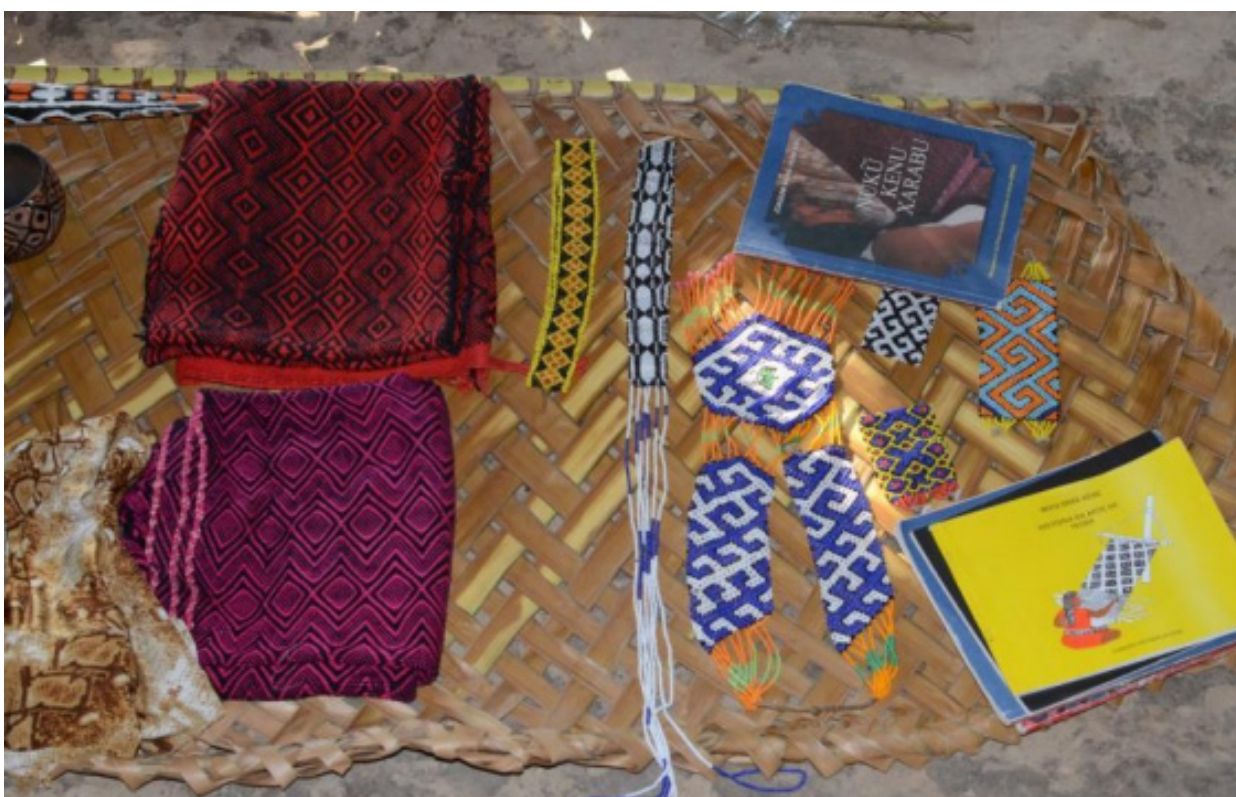

-jiboia (ou sucuri ou, ainda, anaconda), a quem oferece jenipapo para convencer-lhe a realizar o ato sexual. Apaixonado, vai morar com ela no mundo debaixo da água, onde se casam e tem 3 filhos. Um dia, toma o chá do cipó que era consumido pelas jiboias "para ver coisas bonitas". Sob o efeito do cipó, percebe que estava enfeitiçado pela jiboia e resolve voltar para sua casa da superfície.

Após voltar a viver com sua família humana, um dia, entra novamente no rio onde encontrou a mulher-jibóia pela primeira vez, e é visto pelos filhos que teve com ela. Seus filhos-jibóia acabam matando-o, mas antes de morrer ele compartilha com seus familiares humanos a técnica de preparo do chá a partir do cipó, que brota de seu túmulo após seu enterro. O consumo do chá de cipó "dá acesso aos mundos invisíveis dos seres da água, do céu e da floresta" (LAGROU, 1991, p. 169), e os kene vistos sob o efeito da bebia marcam os caminhos entre estes mundos, assim como as mensagens dos yuxin que os habitam. No mito, as associações com o desenho aparecem através do jenipapo oferecido à mulher-jibóia, base da tinta produzida para pintar corpos e artefatos e tingir o algodão utilizado na tecelagem (em algumas versões da narrativa, a mulher-jiboia em sua forma humana também possui o corpo decorado com kene).

$\mathrm{Na}$ segunda narrativa, a serpente mágica aparece novamente, dessa vez para ensinar os desenhos do kene à uma mulher kaxinawá. As versões apresentadas por Lagrou (1991) e Muru (In MAIA, 1999) diferem muito, mas possuem em comum o fascínio exercido pelos desenhos sob os humanos, e a figura da serpente, que possuía os conhecimentos de sua composição e os repassou para mulheres - no caso de Lagrou (1991), um anciã, e no caso de Muru (In MAIA, 1999), uma jovem. De todo modo, o conhecimento foi compartilhado com as outras mulheres kaxinawá, que se tornaram guardiãs do segredo dos desenhos da serpente mágica.

Tecido em tecelagens e cestaria e pintado em cerâmicas e no corpo, o kene é onipresente em tudo que diz respeito à cultura kaxinawá. Construído através do contraste entre figura e fundo, que muitas vezes se confundem no olhar do observador, a característica relacional é fundamental para sua compreensão e apreensão semântica, tanto em termos puramente visuais, quanto no que diz respeito a sua potencialidade de agência na cosmologia da etnia: "onde os traços ligam mundos diferentes, mas inter-relacionados" (LAGROU, 2007, p. 27).
Figura 135: Livros da Coleção Autoria Indígena e artefatos kaxinawá. Fonte: LIMA KAXINAWÁ (2014). 

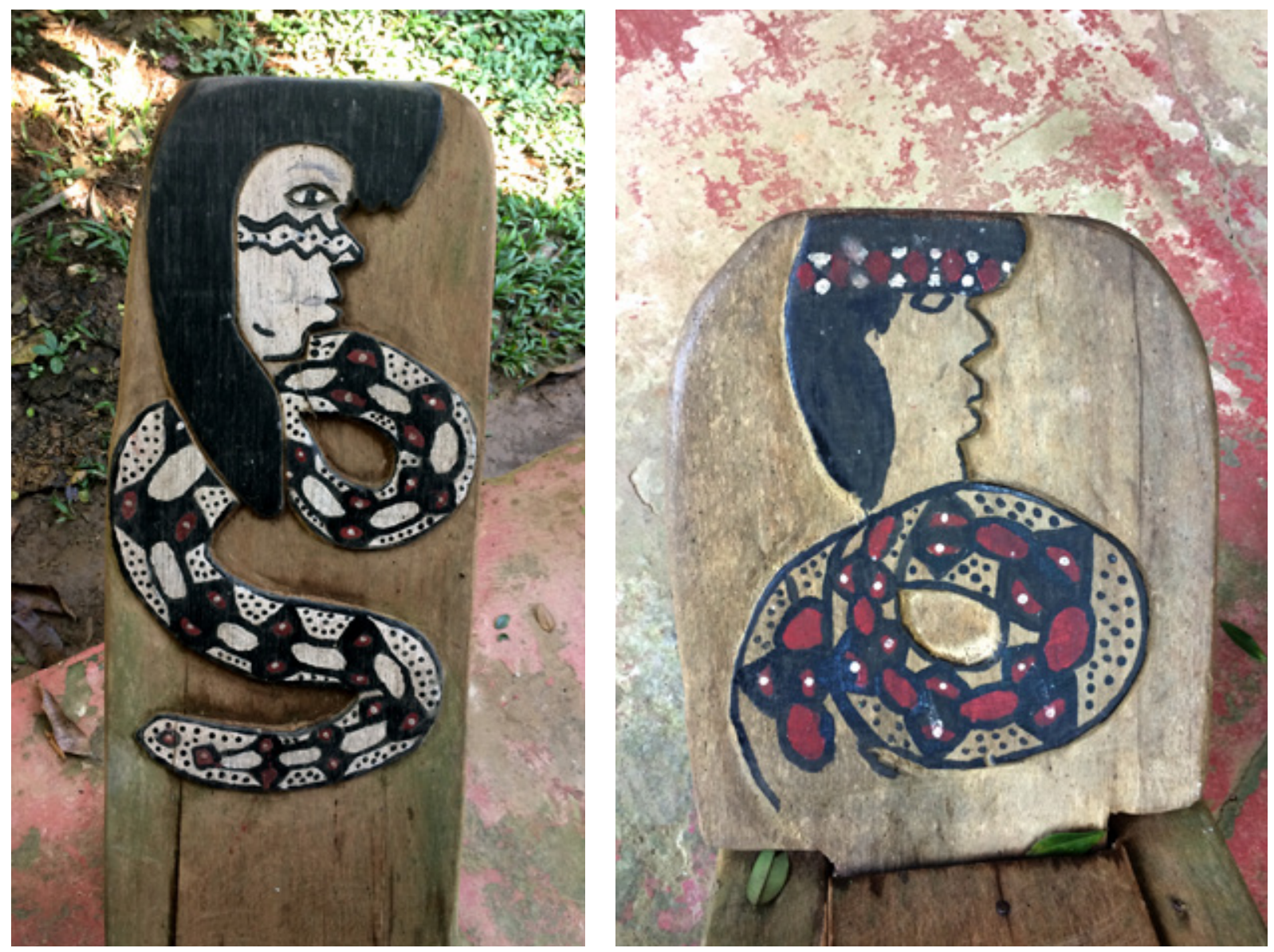

Figuras 136 e 137: Bancos esculpidos por AAFIs kaxinawá com representações da mulher e do homemjibóia. Fonte: Pesquisa de campo, Paiva (2019).
Os kene são classificados a partir de sua configuração visual de acordo com uma nomenclatura específica. Em pesquisa publicada em $2006^{11}$, o professor kaxinawá Joaquim Maná identificou mais de 70 categorias de motivos diferentes. Os dados foram levantados durante uma oficina de tecelagem em algodão promovida pela Apaminktaj e em visita à TI Praia do Carapanã (LIMA KAXINAWÁ, 2006).

Como resultado quantitativo da pesquisa levantamos sessenta e dois (62) tipos de kene utilizados na tecelagem em algodão e doze (12) tipos utilizados na pintura corporal, cerâmica e cestaria. Dos sessenta e dois (62) tipos de kene que foram identificados, 60 ainda estão sendo praticados na atualidade. Os dois (02) kene que não estão sendo utilizados, se encontram em processo de esquecimento pelas artesãs, pois elas tiveram muitas dificuldades em fazer as mostras para o registro. Essa constatação gerou uma discussão entre as participantes da oficina e foi um alerta para as mães e para o povo Huni Kuĩ como um todo, que, se nossos conhecimentos tradicionais não continuarem sendo praticados, no futuro haverá muitas perdas, além das que já tivemos desde o primeiro dia de contato com os brancos. (LIMA KAXINAWÁ, 2006, s/ p.)

Como o levantamento feito por Lima Kaxinawá (2006) indica, a tecelagem é a forma mais tradicional para a reprodução dos kene. Segundo Lagrou (1991, p. 158) “o estilo gráfico Kaxinawá é influenciado pela tecela-

11 Nukũ Kenu Xarabu, publicado pela CPI-AC em 2006. O livro é tratado em detalhes mais adiante, no tópico 4.3 deste capítulo. 
gem" e "a técnica usada tem suas origens na tecelagem incaica". Valoriza-se a capacidade de fazer com que um motivo se transforme em outro sem que a transição seja claramente percebida. Já na pintura corporal, a grossura das linhas e sua precisão e nitidez variam, propositalmente, de acordo com sua função (para crianças, adultos). Para sua aplicação em corpos e rostos, é utilizado um pincel constituído por palitos com pontas embrulhadas em algodão, que é então embebido na tinta de jenipapo, preta, ou urucum, vermelha (LAGROU, 1991, 2007).

Existe uma unidade de estilo que liga todos os corpos e objetos keneya (com desenho), mas o elemento gráfico não é percebido (concebido) pelos Kaxinawá em forma abstrata, desligado da superfície dos corpos (ou seja, não é uma visão platônica das imagens). Esta relação do desenho com a corporalidade do mundo está no âmago de uma experiência visual marcada por uma cosmovisão xamânica; a materialidade no espírito, a relação entre energia e matéria. (LAGROU, 1991, p. 158)

A aplicação de kene varia de acordo com o suporte, e as linhas paralelas podem tornar-se curvas para adaptar-se aos volumes do corpo e do rosto ou de artefatos em cerâmica. Motivos específicos são mais utilizados para a composição de molduras, "funcionam como faixas, delimitando o campo de desenho" enquanto outros tem "tendência a cobrir o campo de desenho inteiro" (LAGROU, 1991, p. 161).

As coisas da natureza, tais como animais e plantas, são classificadas enquanto com ou sem desenho. Há uma grande sensibilidade para perceber a existência de desenhos na natureza por parte dos Kaxinawá, que remonta ao grande valor atribuído ao complexo modelo de arte gráfica que é característico de sua própria produção artística. De modo geral, os "Kaxinawá dividem seu mundo em fenômenos com e sem desenho. O desenho imprime seu padrão, emblema da sua civilização, no seu mundo, símbolo não tanto de domesticação como de interdependência, relação vital" (Ibid., p. 130).

Esta ênfase no desenho é tão marcada, que foi escolhido como elemento crítico na sua auto-imagem. Em comparação com seus vizinhos, que não usam um estilo de desenho que segue elaborados padrões (como os Culina ou os Ashaninka, ou que usam motivos menos labirínticos, como os Yaminawa) os Kaxinawá se distinguem como "povo com desenho". (LAGROU, 2007, p. 109)

Dado o grande significado cultural dos desenhos, há uma estrutura semântica entre objetos e corpos nos quais são aplicados kene (ou seja, que são keneya, desenhados), e aqueles que não o são. Em alguns estágios de desenvolvimento da criança, por exemplo, ela não é (não pode e não deve ser) desenhada (LAGROU, 1991, 2007).

Panelas para cozinhar comida não são pintadas, mas pratos para servir comida podem sê-lo. A pintura é associada a uma fase de novidade na vida do objeto ou da pessoa, uma fase na qual é desejável enfatizar a superfície lisa e perfeita do corpo em questão. O desenho chama a atenção para novidades na experiência visual, que anunciam eventos cruciais da vida. O desenho desaparece com o uso e só é refeito por ocasião de uma festa. Assim, coisas com desenho ocupam um lugar especial na cultura Kaxinawá, como em outras culturas do ocidente amazônico. (LAGROU, 1991, p. 136) 
Retornando à questão da divisão social entre os sexos, tradicionalmente, as mulheres são as guardiãs dos kene, e aos homens não é permitida sua reprodução. Algumas exceções são apontadas por Lagrou (1991, p. 138): as pontas das flechas utilizadas na caça tradicional, pintadas com desenhos que "são geométricos como os das mulheres, mas mostram diferenças de estilo (...) por não apresentar o traço fino de linhas labirínticas, marca distintiva do estilo gráfico Kaxinawá", e "pode ser que também pintassem seus chapéus de palha, as máscaras rituais de cuia e as bonecas de pau para as crianças" (Ibid., 137). Esses artefatos, contudo, já eram dificilmente encontrados em campo pela pesquisadora em 1991, e os registros apresentados em sua dissertação foram feitos a partir de coleções preservadas em museus.

Os desenhos que homens e rapazes faziam para mim, ao receber papel e lápis, sempre eram bem diferentes daqueles que as mulheres desenhavam. Enquanto elas preenchiam o papel com desenhos geométricos, os homens desenhavam sempre figuras: animais, gente, casas e plantas. E este tipo de desenho não é kene, é dami. (LAGROU, 1991, p. 139)

Dami é o nome dado às representações figurativas tridimensionais ${ }^{12}$, palavra que também significa "transformação, figura, boneca" e passou a ser utilizada para nomear os desenhos figurativos após o contato com o branco (LAGROU, 1991, p. 140). Quando um desenho figurativo fica muito próximo à realidade, ele passa a se chamar yuxin, "espírito mesmo. Assim 'foto' é yuxin; não transforma ou representa a imagem da coisa, mas tira sua sombra, parte da sua alma" (Ibid.).

O desenho em papel, figurativo ou não, está diretamente relacionado aos contextos de contato com o branco, tendo sido introduzido no contexto missionário e escolar (LAGROU, 2007, p. 118). Contexto este que, assim como os cursos de formação de professores da CPI-AC, é frequentado quase que exclusivamente por homens ${ }^{13}$. Contudo, os kene são encontrados em abundância nas ilustrações produzidas pelos professores em formação, assim como naquelas publicadas nos livros da Coleção Autoria Indígena. A resposta para essa contradição talvez se encontre no relato de Lagrou (1991).

Somente no segundo dia de viagem, alguns rapazes, de 16 a 18 anos, pediram-me papel e caneta. O desenho deles não tinha nada a ver com as linhas labirínticas e geométricas com que Maria e Glória preenchiam o papel. Eles desenhavam pessoas, pássaros, animais e casas. Perguntei se isto era kene também, e responderam-me que não, que isto era dami, boneca, imagem, outra coisa; que homem não fazia kene e que estes desenhos de figuras eles tinham aprendido a fazer na escola.

Já no penúltimo dia de viagem, o velho senhor Agosto, sogro do novo liderança de Moema, pediu-me, rindo como quem está pedindo algo totalmente inusitado, papel e caneta. Ele quase não tinha saído do lado de Maria,

12 Tridimensional no sentido do que é representado, e não necessariamente da representação em si, tento em vista que a planificação é uma das principais características da ilustração figurativa kaxinawá, conforme será explorado mais adiante.

13 McCallum (2007, p. 588) atenta para a necessidade de se produzirem mais estudos a respeito das questões de gênero nas escolas kaxinawá: " $E$, ainda, no que diz respeito à objetivização e à manipulação de "cultura" no "movimento pró-cultura", muitas vezes outorgadas à agência masculina, como se inserem na dinâmica de gênero?". 
enquanto esta estava desenhando e não resistiu à tentação. Ele fez, com mão firme e ligeira uns desenhos muito interessantes; lembravam o kene de Maria e Glória, mas eram mais soltos e muito expressivos. Não seguiam o padrão mais equilibrado e refinado dos desenhos das mulheres. Seus desenhos provocaram risos e comentários de todos e Maria, parecendo levemente irritada, disse que isso era "kenemaki" (não é desenho), "isso que Agosto está fazendo, não presta". Agosto concordou com o julgamento, rindo. (Ibid., p. 5, grifos no original)

Retornando à citação do professor Agostinho Muru em A Arte do Kene: "nos dias de hoje, qualquer tempo é tempo para aprender kene. Crianças, jovens e adultos reelaboram tradições nesses desafios presentes na reconquista de sua memória cultural" (MURU et al., s/ d., p. 12). Os kene têm sido utilizados nos materiais didáticos produzidos pela CPI-AC não apenas como parte das ilustrações, mas também inspiração para ferramentas educacionais.

Um exemplo interessante (e talvez o mais significativo) da utilização de kene como ferramenta educativa é viso na cartilha de pré-alfabetização As Primeiras Letras (publicada em 1991). A cartilha foi pensada a partir da dificuldade apresentada pelos alunos na apreensão da letra cursiva, apontada pelos professores. Dessa forma, decidiu-se explorar as relações entre o desenho de formas básicas que compõem os kene e a "letra de forma maiúscula" que "por seus traços retos e tamanhos homogêneos, vem mostrando-se de mais fácil domínio que a cursiva e script" (MONTE, 1987, p. 74). Na mesma cartilha, exercícios de repetição também utilizam kene como base para reprodução.

Na Cartilha de Matemática (1990) motivos geométricos semelhantes são utilizados para trabalhar repetição e simetria, mas como os motivos são bastante básicos e a cartilha produzida por professores de diversas etnias, não é possível dizer com certeza que foram inspirados nos kene kaxinawá (no caso de As Primeiras Letras, os registros de Monte (1987) permitem afirmar com certeza.), especialmente tendo em vista que os Yawanawa também possuem manifestações gráficas semelhantes as quais também chamam de kene.
Figura 138: Páginas do miolo de As Primeiras Letras ( $1^{\circ}$ ed., 1991). Fonte: Pesquisa de campo, Paiva (2019).

\section{DESENHE IGUAL:}

(6)

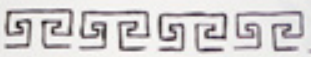

$\mathbf{T}$

एव एव एव एव

$\mathrm{S}$

周畞 四

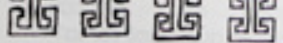

$\frac{1}{24}$ 


\begin{tabular}{|c|c|c|c|c|}
\hline & TítULo & ANO & ETNIA & AUTORIA \\
\hline 1 & CARTILHA DO ÍNDIO SERINGUEIRO & 1983 & VÁRIAS & COLETIVA \\
\hline 2 & $\begin{array}{l}\text { O JACARÉ SERVIU DE PONTE - } \\
\text { ESTÓRIAS DE HOJE E DE ANTIGAMENTE }\end{array}$ & 1984 & VÁRIAS & COLETIVA \\
\hline 3 & $\begin{array}{l}\text { ESCOLAS DA FLORESTA - } \\
\text { CARTILHA DE PRÉ-ALFABETIZAÇÃO }\end{array}$ & $198-$ & VÁRIAS & COLETIVA \\
\hline 12 & CARTILHA KAXINAWÁ (NÃO HÁ TíTULO NA CAPA) & $198-$ & KAXINAWÁ & COLETIVA \\
\hline 4 & FÁBRICA DO ÍNDIO & 1985 & VÁRIAS & COLETIVA \\
\hline 5 & ESCOLAS DA FLORESTA & 1986 & VÁRIAS & COLETIVA \\
\hline 6 & CARTILHA DO ÍNDIO SERINGUEIRO ( $2^{\circ}$ ED.) & 1988 & VÁRIAS & COLETIVA \\
\hline \multirow[t]{2}{*}{7} & CARTILHA KAXINAWÁ: HATXA HUNI KUĨ & 1989 & KAXINAWÁ & COLETIVA \\
\hline & $\begin{array}{l}\text { CARTILHA DE EDUCAÇÃO MATEMÁTICA PARA } \\
\text { CRIANCAS DA FLORESTA }\end{array}$ & 1990 & VÁBIAS & COLETIVA \\
\hline 9 & $\begin{array}{l}\text { IV CURSO DE FORMAÇÃO DE MONITORES DE SAÚDE - } \\
\text { CADERNO DE ATIVIDADES }\end{array}$ & 1991 & VÁRIAS & COLETIVA \\
\hline 10 & AS PRIMEIRAS LETRAS & 1991 & VÁRIAS & COLETIVA \\
\hline 11 & CARTILHA DE GEOGRAFIA / GEOGRAFIA INDÍGENA & 1992 & VÁRIAS & COLETIVA \\
\hline 13 & LIVRO DE MATEMÁTICA 1 & 1993 & VÁRIAS & COLETIVA \\
\hline 14 & LIVRO DE MATEMÁTICA 2 & 1993 & VÁRIAS & COLETIVA \\
\hline 15 & KENE & 1994 & KAXINAWÁ & COLETIVA \\
\hline 16 & GEOGRAFIA KAXINAWÁ & 1994 & KAXINAWÁ & COLETIVA \\
\hline 17 & SHENIPABU MIYUI - HISTÓRIA DOS ANTIGOS & 1995 & KAXINAWÁ & COLETIVA \\
\hline 18 & CADERNO DE ALFABETIZAÇÃO & 1995 & VÁRIAS & COLETIVA \\
\hline 19 & HISTORINHAS INDÍGENAS DA FLORESTA & 1995 & VÁRIAS & COLETIVA \\
\hline 20 & NUKŪ MIMAWA & 1995 & KAXINAWÁ & $\begin{array}{l}\text { JOAQUIM MANÁ, } \\
\text { ISAÍAS SALES IBÃ }\end{array}$ \\
\hline 21 & ATLAS GEOGRÁFICO INDÍGENA DO ACRE & 1996 & VÁRIAS & COLETIVA \\
\hline 22 & HISTÓRIA INDÍGENA & 1996 & VÁRIAS & COLETIVA \\
\hline 23 & AS PRIMEIRAS LETRAS ( $2^{\circ}$ ED.) & 1996 & VÁRIAS & COLETIVA \\
\hline 24 & ATLAS GEOGRÁFICO INDÍGENA DO ACRE (2 ED.) & 1998 & VÁRIAS & COLETIVA \\
\hline 25 & $\begin{array}{l}\text { APRENDENDO PORTUGUÊS NAS ESCOLAS DA } \\
\text { FLORESTA ( } 2^{\circ} \text { ED.) }\end{array}$ & 1997 & VÁRIAS & COLETIVA \\
\hline 26 & CADERNO DE ALFABETIZAÇÃO (2 ED.) & 1997 & VÁRIAS & COLETIVA \\
\hline 27 & YUMEBŨ MIYUI - MAE BI KENA & 1997 & KAXINAWÁ & JOAQUIM MANÁ \\
\hline
\end{tabular}


Os Kaxinawá do Acre e os livros da Coleção Autoria Indígena: uma análise em design editorial

\begin{tabular}{|c|c|c|c|c|}
\hline & TítULo & ANO & ETNIA & AUTORIA \\
\hline 28 & CHEGOU O TEMPO DE PLANTAR AS FRUTAS & 1998 & VÁRIAS & COLETIVA \\
\hline 29 & VAMOS CRIAR PEIXES & 1999 & VÁRIAS & COLETIVA \\
\hline 30 & $\begin{array}{l}\text { PRA TRANSAR TEM QUE SE PROTEGER - } \\
\text { CIÊNCIAS DA FLORESTA }\end{array}$ & 1999 & VÁRIAS & COLETIVA \\
\hline 31 & CADERNO DE PESQUISA & 1999 & VÁRIAS & COLETIVA \\
\hline 32 & CADERNO DE PESQUISA ( $2^{\circ}$ ED.) & 2000 & VÁRIAS & COLETIVA \\
\hline 33 & CHEGOU O TEMPO DE PLANTAR AS FRUTAS ( $2^{\circ}$ ED.) & 2000 & VÁRIAS & COLETIVA \\
\hline 34 & KENE (2॰ ED.) & 2000 & KAXINAWÁ & COLETIVA \\
\hline 35 & MIYUI MIMÃ KENE - HISTÓRIA DA ARTE DE TECER & 2000 & KAXINAWÁ & ISAÍAS SALES IBÃ \\
\hline 36 & GEOGRAFIA HUNI KUI (2 ED.) & 2001 & KAXINAWÁ & COLETIVA \\
\hline 37 & NUKU MIMAWA XARABU ( $2^{\circ}$ ED.) & 2001 & KAXINAWÁ & $\begin{array}{l}\text { JOAQUIM MANÁ, } \\
\text { ISAÍAS SALES IBÃ, } \\
\text { PAULO LOPES SIÃ }\end{array}$ \\
\hline 38 & HISTORINHAS INDÍGENAS DA FLORESTA & 2001 & VÁRIAS & COLETIVA \\
\hline 39 & NUKŨ MIMAWA XARABU (2 ED.) & 2002 & KAXINAWÁ & $\begin{array}{l}\text { JOAQUIM MANÁ, } \\
\text { ISAÍAS SALES IBÃ, } \\
\text { PAULO LOPES SIÃ }\end{array}$ \\
\hline 40 & ÍNDIOS DO ACRE - HISTÓRIA E ORGANIZAÇÃO (2 ED.) & 2002 & VÁRIAS & COLETIVA \\
\hline 41 & CADERNO DE REFLEXÃO DO PROFESSOR INDÍGENA & 2005 & VÁRIAS & COLETIVA \\
\hline 42 & NIXI PAE - O ESPÍRITO DA FLORESTA & 2006 & KAXINAWÁ & ISAÍAS SALES IBÃ \\
\hline 43 & NUKŨ KENU XARABU & 2006 & KAXINAWÁ & JOAQUIM MANÁ \\
\hline 44 & $\begin{array}{l}\text { APRENDENDO COM A NATUREZA E CONSERVANDO } \\
\text { NOSSOS CONHECIMENTOS CULTURAIS }\end{array}$ & 2006 & VÁRIAS & COLETIVA \\
\hline 45 & $\begin{array}{l}\text { PLANTAS MEDICINAIS - DOENÇAS E CURAS DO POVO } \\
\text { HUNĨ KUI }\end{array}$ & 2006 & KAXINAWÁ & $\begin{array}{l}\text { EDSON MEDEIROS } \\
\text { IXÃ KAXINAWÁ }\end{array}$ \\
\hline 46 & A ARTE DO KENE & 2006 & KAXINAWÁ & COLETIVA \\
\hline 47 & UĨ BENA & 2006 & KAXINAWÁ & COLETIVA \\
\hline 48 & DISCUTINDO PROBLEMAS, PENSANDO SOLUÇÕES & 2007 & VÁRIAS & COLETIVA \\
\hline 49 & HUNI MEKA & 2007 & KAXINAWÁ & COLETIVA \\
\hline 50 & $\begin{array}{l}\text { PLANO DE GESTÃO TERRITORIAL E AMBIENTAL TERRA } \\
\text { INDÍGENA KAXINAWÁ E ASHANINKA DO RIO BREU }\end{array}$ & 2007 & VÁRIAS & COLETIVA \\
\hline 51 & $\begin{array}{l}\text { PLANTAS MEDICINAIS - DOENÇAS E CURAS DO POVO } \\
\text { HUNI KUĨ ( } 2^{\circ} \text { ED.) }\end{array}$ & 2009 & KAXINAWÁ & $\begin{array}{l}\text { EDSON MEDEIROS } \\
\text { IXÃ KAXINAWÁ }\end{array}$ \\
\hline
\end{tabular}

Tabela 2. Levantamento dos livros da Coleção Autoria Indígena com participação de autores kaxinawá. A segunda edição de Plantas Medicinais - Doenças E Curas Do Povo Huni Kuĩ foi incluída pois, apesar de lançada em 2009, trata-se do mesmo projeto utilizado na primeira edição, produzida em 2006. Fonte: Pesquisa de campo, Paiva (2019). 
Figura 139: Página do miolo de As Primeiras Letras $\left(1^{\circ}\right.$ ed., 1991).

Fonte: Pesquisa de campo, Paiva (2019)

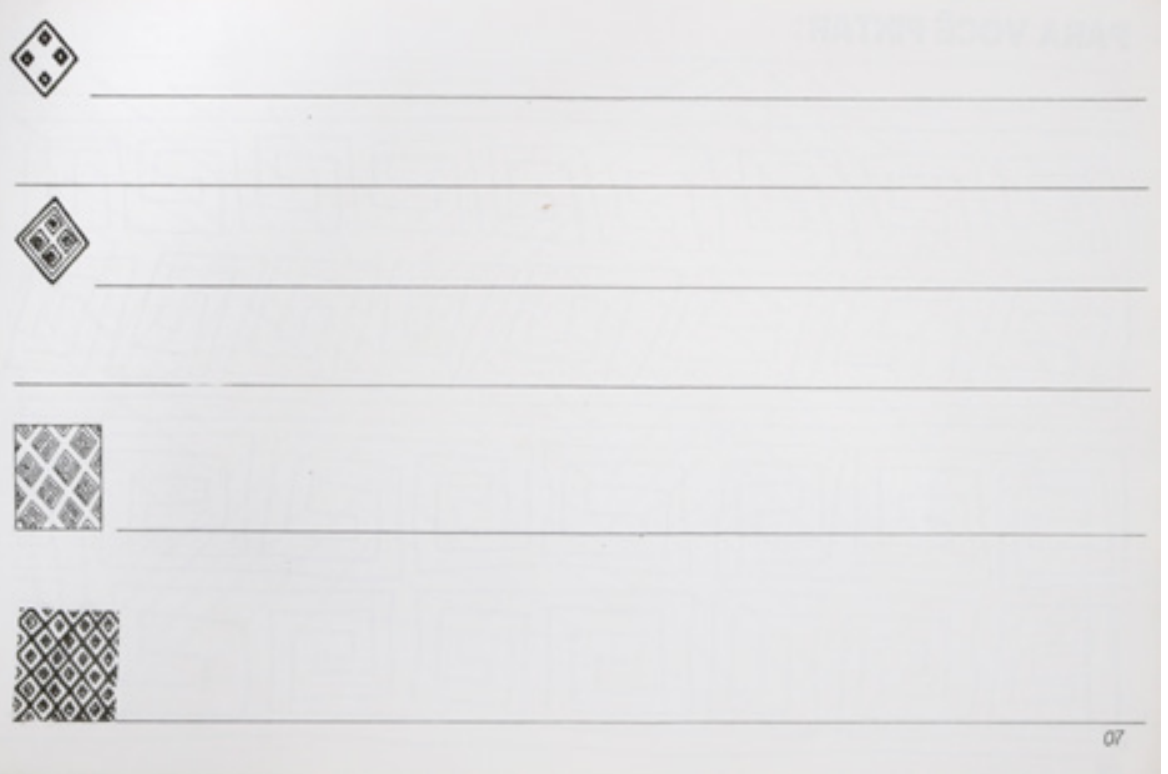

\subsection{Autores e publicações kaxinawá da Coleção Autoria Indígena}

Ao todo, professores e pesquisadores kaxinawá participaram de 51 dos 86 livros que compõem a Coleção Autoria Indígena. Destes, 18 foram especificamente feitos por professores kaxinawá, enquanto 33 foram escritos por autores de diversas etnias. Dos especificamente kaxinawá, 9 foram escritos por até 3 autores, e 9 foram escritos por mais de 3 .

De acordo com a tabela 2, se pode perceber que Edson Medeiros Ixã Kaxinawá, Joaquim Maná, Isaías Sales Ibã, e Agostinho Manduca Muru são alguns dos principais autores e pesquisadores kaxinawás a participar da Coleção Autora Indígena. A seguir, buscou-se reunir algumas informações importantes sobre os mesmos, tais como suas principais pesquisas e especialidades temáticas.

\section{Edson Medeiros Ixã}

Nascido na aldeia Bondoso, em 1962, às margens do igarapé Matapaste, afluente do rio Jordão (IXÃ KAXINAWÁ, 2006), fez parte da primeira geração de professores formados nos cursos de formação de professores da CPI-AC (participou do segundo curso). Iniciou sua prática docente em 1985 (MONTE, 1996). Desenvolveu pesquisas sobre as plantas medicinais tradicionais, sobre as quais fez um minucioso levantamento, posteriormente publicado pela CPI-AC (IXÃ KAXINAWÁ, 2006). Fez várias viagens de formação e participou de seminários no exterior. Chegou a fazer parte do início do projeto sobre os cantos do huni $m e k a^{14}$, que deu origem ao livro homônimo lançado em 2007, antes de seu falecimento em 2006.

\section{Joaquim Maná (Joaquim Paulo de Lima)}

Nasceu na TI Praia do Carapanã em 1977 e iniciou sua experiência de formação na primeira viagem de assessoria, com Dedê Maia e Keilah Diniz em 1975. Posteriormente, em 1983, participou do primeiro curso de formação de professores indígenas da CPI-AC. Graduou-se em Ciências Sociais

14 Cantos para o consumo do cipó, nixi pae (ayahuasca). Os txana guardam o conhecimento desses cantos, geralmente guiando e presidindo o ritual para o seu consumo. Os cantos são classificados de acordo com seu potencial para potencializar ("chamar a força") ou minimizar ("diminuir a força") o efeito da bebida. 

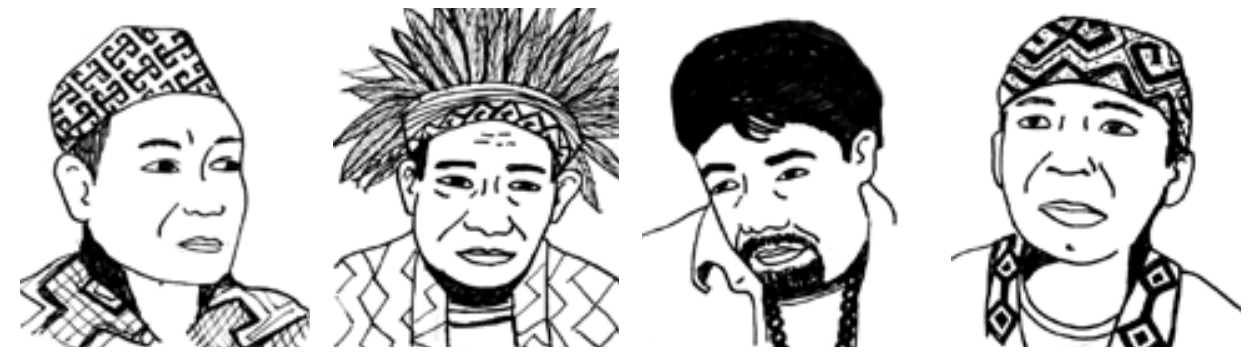

Figura 140:

Professores Joaquim Paulo de Lima Maná, Agostinho Manduca, Edson Medeiros Ixã e Isaías Sales Ibã, da esquerda para a direita. Fonte: Adaptação da autora.

\begin{tabular}{|c|c|c|c|}
\hline TÍTULO & ANO & CATEGORIA & LÍGNUA \\
\hline CARTILHA KAXINAWÁ: HATXA HUNI KUĨ & 1989 & ALFABETIZAÇÃO EM HÃXTA KUĨ & HÃXTA KUĨ \\
\hline KENE & 1994 & ALFABETIZAÇÃO EM HÃXTA KUĨ & HÃXTA KUĨ \\
\hline GEOGRAFIA KAXINAWÁ & $1994^{*}$ & LIVRO DE GEOGRAFIA & HÃXTA KUĨ \\
\hline SHENIPABU MIYUI - HISTÓRIA DOS ANTIGOS & 1995 & COLETÂNEA DE HISTÓRIAS & BILÍNGUE \\
\hline NUKŪ MIMAWA & 1995 & COLETÂNEA DE CANTOS & HÃXTA KUĨ \\
\hline YUMEBŪ MIYUI - MAE BI KENA & 1997 & - & HÃXTA KUĨ \\
\hline KENE $\left(2^{\circ}\right.$ ED.) & 2000 & ALFABETIZAÇÃO EM HÃXTA KUĨ & HÃXTA KUĨ \\
\hline \multicolumn{4}{|l|}{ MIYUI MIMÃ KENE - HISTÓRIA DA ARTE } \\
\hline DE TECER & 2000 & TECELAGEM E KENE & BILÍNGUE \\
\hline GEOGRAFIA HUNI KUĨ (2 ED.) & 2001 & LIVRO DE GEOGRAFIA & HÃXTA KUĨ \\
\hline NUKŨ MIMAWA XARABU (2 ED.) & $2001^{*}$ & COLETÂNEA DE CANTOS & HÃXTA KUĨ \\
\hline NUKŨ MIMAWA XARABU ( $2^{\circ}$ ED.) & 2002 & COLETÂNEA DE CANTOS & HÃXTA KUĨ \\
\hline NIXI PAE - O ESPÍRITO DA FLORESTA & 2006 & COLETÂNEA DE CANTOS & $\begin{array}{l}\text { HÃXTA KUĨ E } \\
\text { PORTUGUÊS }\end{array}$ \\
\hline NUKŨ KENU XARABU & 2006 & TECELAGEM E KENE & HÃXTA KUIN \\
\hline PLANTAS MEDICINAIS - DOENÇAS E CURAS & & & HÃXTA KUĨ E \\
\hline DO POVO HUNI KUĨ & 2006 & MEDICINA TRADICIONAL & PORTUGUÊS \\
\hline A ARTE DO KENE & $2006^{\star}$ & TECELAGEM E KENE & PORTUGUÊS \\
\hline UĨ BENA & 2006 & MANEJO FLORESTAL & HÃXTA KUĨ \\
\hline HUNI MEKA & 2007 & COLETÂNEA DE CANTOS & $\begin{array}{l}\text { HÃXTA KUĨ E } \\
\text { PORTUGUÊS }\end{array}$ \\
\hline $\begin{array}{l}\text { PLANTAS MEDICINAIS - DOENÇAS E CURAS } \\
\text { DO POVO HUNI KUĨ ( } 2^{\circ} \text { ED.) }\end{array}$ & 2009 & MEDICINA TRADICIONAL & $\begin{array}{l}\text { HÃXTA KUĨ E } \\
\text { PORTUGUÊS }\end{array}$ \\
\hline
\end{tabular}

Tabela 3: Levantamento e categorização dos livros de autores kaxinawá que fazem parte da Coleção Autoria Indígena. Os anos marcados com * não constam em suas respectivas publicações, tendo sido utilizados os dados dos registros da CPI-AC. Utilizou-se o termo "bilíngue" para livros que apresentam o mesmo conteúdo em português e hãxta kuĩ, enquanto aqueles que não são classificados dessa forma apresentam conteúdos ditintos nas duas línguas - geralmente textos introdutórios e posfácios. Os livros onde há apenas uma breve introdução ou apresentação em português foram classificados como em hãxta kuĩ. Todas as folhas de créditos de todos os livros são escritas em português.

Fonte: Pesquisa de campo, Paiva (2019). 
na Universidade Federal do Mato Grosso do Sul (UFMS), e seu trabalho de conclusão de curso resultou no livro Nukũ Kenu Xarabu, publicado em 2006 pela CPI-AC. Fez mestrado e doutorado na Universidade de Brasília (UNB). Foi o primeiro indígena brasileiro a receber o título de doutor em linguística ${ }^{15}$. Em sua tese, propõe uma gramática da língua hãxta kuĩ sob uma perspectiva linguística antropológica. Segundo seu Currículo Lattes, trabalhou como Técnico Pedagógico da Equipe de Educação Escolar Indígena, na Secretaria de Educação do Estado do Acre (2017-2019) e está cursando o pós-doutorado no Programa de Pós-Graduação em Letras: Linguagem e Identidade, da Universidade Federal do Acre (UFAC). Também é Coordenador tradicional e técnico na área de educação e cultura na Federação do Povo Huni Kuĩ do Estado do Acre (FEPHAC) ${ }^{16}$. Desenvolveu pesquisas a respeito dos cantos tradicionais kaxinawá, do levantamento dos kene e da configuração escrita da língua hãxta kuĩ.

\section{Isaías Sales Ibã}

Nascido no seringal Fortaleza, nas margens do rio Jordão, em 1964, participou do primeiro curso de formação de professores indígenas da CPI-AC, e de 22 dos mesmos, no total (IBÃ Kaxinawá, 2006). É formado em licenciatura indígena e desenvolveu pesquisas sobre os cantos do huni meka, assunto pelo qual sempre se interessou, a partir da aprendizagem dos cantos com seu pai (CPI-AC, 2007). Integra o coletivo artístico MAHKU (Movimento dos Artistas Huni Kuĩ), e produz quadros inspirados nos rituais do nixi pae $^{17}$. Junto ao MAHKU já realizou exposições em várias capitais brasileiras (Rio Branco, Belo Horizonte, Brasília) e na França. Também produziu pesquisas e vídeos junto ao LABI (Laboratório de Imagem e Som da Universidade Federal do Acre). Foi indicado ao Prêmio Pipa - Janela para a arte contemporânea em $2016^{18}$.

\section{Agostinho Manduca Mateus Muru}

Nascido no seringal Sereteama, às margens do rio Taraucá, em 1944, tornou-se uma das primeiras lideranças políticas kaxinawá, ainda na década de 1970, e, segundo conta, após viajar por 15 TIs para advogar a luta fundiária, durante o transe da ayahuasca recebeu um chamado para estudar e conhecer sua cultura. A partir daí, passou a estudar cantos e conhecimentos tradicionais Kaxinawá, tornando-se pajé e txana (MATEUS, 2012). Além da participação em publicações da CPI-AC, foi importante pesquisador e organizador do Livro Vivo e do Livro da Cura ${ }^{19}$ - este último foi seu último projeto, em 2011, ano de seu falecimento.

15 Fonte: "Pesquisador é primeiro índio a receber título de doutor em linguística pela UnB", reportagem de Agência Brasil, 19/12/2014, disponível em: http://agenciabrasil.ebc. com.br/cultura/noticia/2014-12/pesquisador-primeiro-indio-receber-titulo-de-doutor-em-linguistica-pela-unb (acesso em janeiro de 2020).

16 Segundo o site da instituição, disponível em: https://fephac.wixsite.com/fephac/people (acesso em janeiro de 2020).

17 Cipó, ayahuasca.

18 De acordo com o site do prêmio, disponível em https://www.premiopipa.com/pag/ isaias-sales (acesso em janeiro de 2020).

19 Livro Vivo - Una Hiwea, publicação organizada por Muru e publicada pelo núcleo de pesquisa Literaterras, da Faculdade de Letras da UFMG em 2012; e Una Isĩ Kayawa - Livro da Cura do povo Huni Kuĩ do rio Jordão, organizado por Muru e pelo biólogo Alexandre Quinet, um projeto do Instituto de Pesquisas Jardim Botânico do Rio de Janeiro, publicado pela Dantes Editora em 2014. Ambas publicações exploram os conhecimentos Kaxinawá sobre medicina tradicional, plantas, vegetais e rituais de cura (MATEUS, 2012; MURU, QUINET, 2014). 

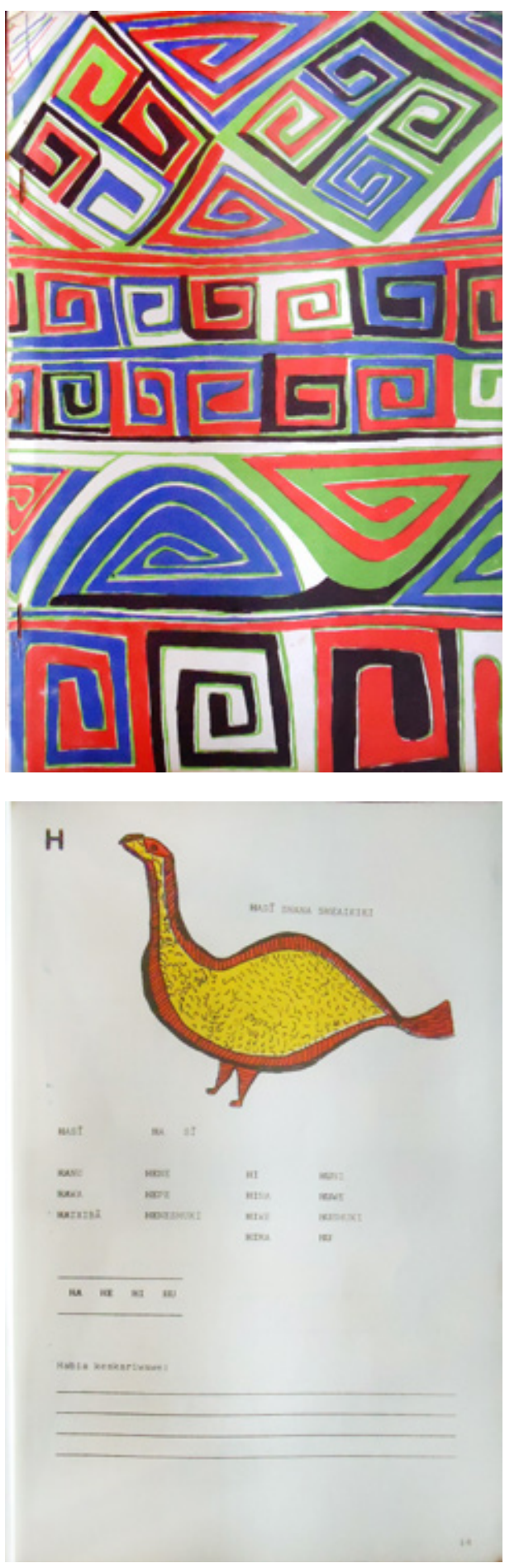
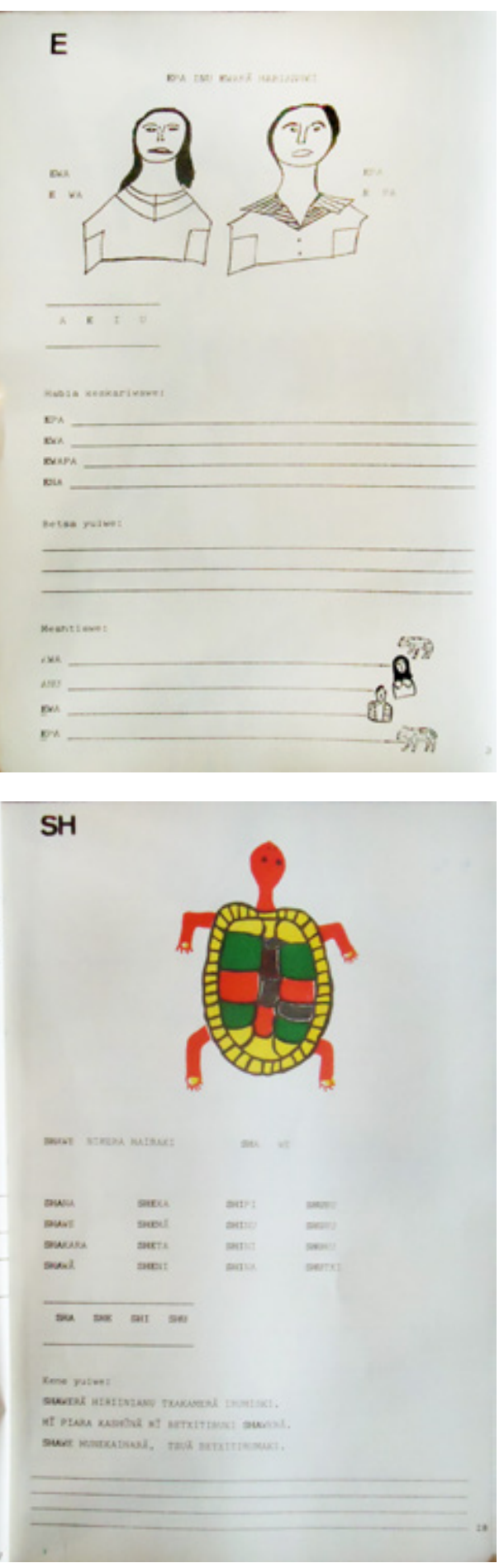

Figuras 141 e 142:

Capa e página do miolo de Cartilha Kaxinawá (1989). A capa apresenta a mesma composição da Cartilha do índio Seringueiro (1983), como pode ser visto na figura 40, na pág. 86. Fonte: Pesquisa de campo, Paiva (2019).

Figuras 143 e 144: Páginas do miolo de Cartilha Kaxinawá (1989). A composição gráfica segue o modelo estabelecido nos outros impressos da época. Fonte: Pesquisa de campo, Paiva (2019).

Com relação aos temas dos livros de autoria exclusivamente kaxinawá publicados pela CPI-AC, além daqueles compartilhados com outras etnias: apostilas para alfabetização em português, livros de geografia e história indígena, apostilas de matemática e livros de leitura; tem-se as categorias específicas para os livros exclusivamente desenvolvidos por e voltados para a etnia Kaxinawá, conforme se lê na tabela 3.

\section{Apostilas de alfabetização e geografia}

A primeira cartilha de alfabetização em hãxta kuĩ encontrada no acervo do CDPI data de 1989. A Cartilha Kaxinawá: Hãxta Huni Kũ̃ foi produzida por oito professores (dentre eles Joaquim Maná e Edson Ixã), e organizada por Vera Olinda Sena e Nietta Lindenberg Monte. Foi impressa na Gráfica dos Povos da Floresta e segue o mesmo modelo de boa parte dos materiais 

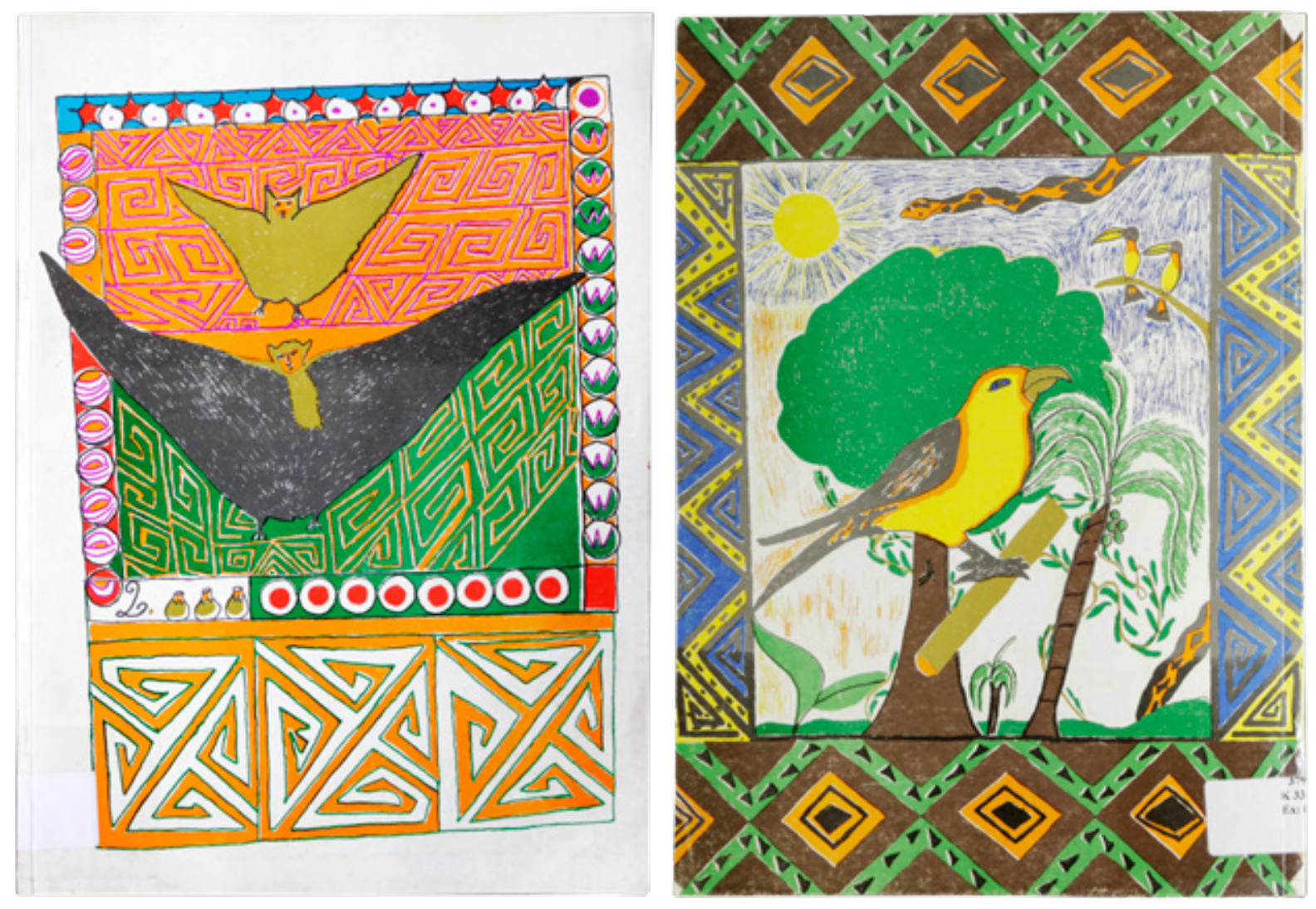

Figuras 145 e 146: produzidos durante as décadas de 1980 e 1990. Seu conteúdo é formatado Primeira e quarta capas da segunda edição da cartilha para alfabetizção

em hãxta kuĩ Kene (2000). Fonte: Pesquisa de campo, Paiva (2019) a partir das palavras geradoras, apesar de também haverem outros tipos de exercícios. O miolo é totalmente ilustrado, no estilo gráfico de reprodução característico desse período: cores vibrantes em áreas chapadas, com grande ênfase para as linhas de contorno. Sua capa é a mesma da Cartilha do Índio Seringueiro (a primeira cartilha publicada pela CPI-AC, em 1983).

Em 1994 uma nova cartilha é produzida, com o título Kene. Não foi encontrado nenhum exemplar dessa primeira edição em acervo, porém a informação do ano de sua publicação está registrado no texto de apresentação da segunda edição, publicada em 2000. O texto de apresentação é o único conteúdo em português, fora a página de créditos, e também informa que a segunda edição apresenta alguns exercícios revisados e que o material foi desenvolvido para "incentivar a leitura e a escrita nas escolas indígenas kaxinawá". Apesar de não ter sido impressa na gráfica interna (que já não estava mais em funcionamento), as ilustrações ainda apresentam o mesmo aspecto de áreas chapadas e cores vibrantes. Mais uma vez, a configuração do miolo é composta basicamente pelas ilustrações acompanhadas dos enunciados e dos respectivos espaços para as respostas dos exercícios.

Também em 1994 é publicado o livro Geografia Kaxinawá, o primeiro livro de geografia especificamente kaxinawá. Os conteúdos abrangem versos, mapas, narrativas mitológicas e ilustrações que abordam os conhecimentos geográficos a partir da combinação entre os pontos de vista indígenas e não indígenas. Destacam-se especialmente os mapas ${ }^{20}$, reproduzidos com variedade de cores e que representam desde o território estadual ao

20 A pesquisa de mestrado de Renato Antonio Gavazzi, coordenador da disciplina de geografia nos cursos de formação de professores e, posteriormente, de agentes agroflorestais, explora em detalhes os métodos cartográficos desenvolvidos (GAVAZZI, R. A. Agrofloresta e cartografia indígena: a gestão territorial e ambiental nas mãos dos agentes agroflorestais indígenas do Acre. Dissertação de mestrado, Faculdade de Filosofia, Letras e Ciências Humanas. Universidade de São Paulo, São Paulo: 2012). 


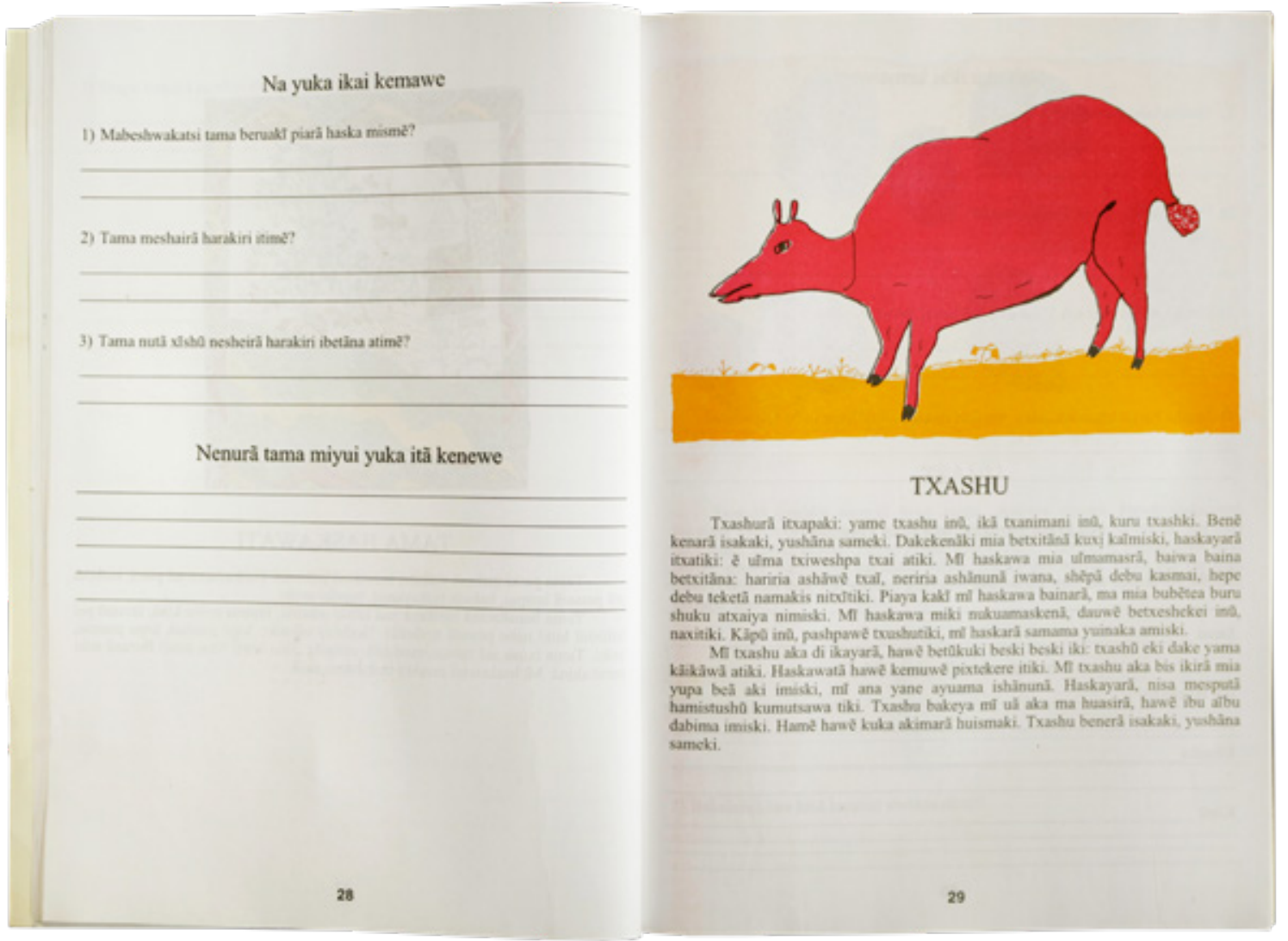

das aldeias, bacias hidrográficas específicas, etc. As ilustrações, em geral, tem muito destaque na composição das páginas, ocupando-as, às vezes, por completo. Este material foi reeditado em 2001, com o título Geografia Huni Kũ̃, ainda mantendo as mesmas características técnicas da primeira edição (conforme mencionado anteriormente, linhas destacadas, áreas sólidas de

Figura 147: Páginas do miolo da segunda edição da cartilha Kene (2000). Fonte: Pesquisa de campo, Paiva (2019). cores vibrantes).

\section{Coletânea de histórias}

Shenipabu Miyui - História dos Antigos, publicado em 1996, foi a primeira coletânea de histórias publicada pela CPI-AC voltada para apenas uma etnia $^{21}$. Cerca de 12 narrativas tradicionais são apresentadas, em português e hãxta kuĩ, acompanhadas de ilustrações que se alternam com o texto, ocupando às vezes páginas inteiras, às vezes parcelas da mancha impressa. Há uma apresentação, que abrange tanto o percurso histórico e social da etnia quanto a produção do livro (o processo de gravação, transcrição e digitação das histórias), inclusive a defesa da importância da produção de livros em língua indígena e da valorização da autoria indígena, escrita por Nietta Lindenberg Monte. Várias fotografias acompanham esse texto, algumas históricas e outras que documentam o cotidiano das aldeias contemporâneo à produção do livro.

\section{Coletâneas de cantos}

Nukũ Mimawa (1995), foi o primeiro "livro de música" kaxinawá publicado pela CPI-AC, conforme consta em sua introdução (escrita em apenas em português). Reunidos a partir de gravações feitas com anciões das TIs do rio Jordão, Purus e Tarauacá, a produção do livro começa em 1990, quando Joaquim Maná fez um "treinamento de fonemas e fonologia em Recife, com a famosa professora linguista Dra. Adair Palacio na Universidade Federal de Pernambuco" para que pudesse transcrever o material gravado em fitas de

21 Este é um dos livros da coleção que recebeu grande visibilidade, conforme mencionado anteriormente, através de uma reedição feita pela editora da UFGM, publicada em 2000. 

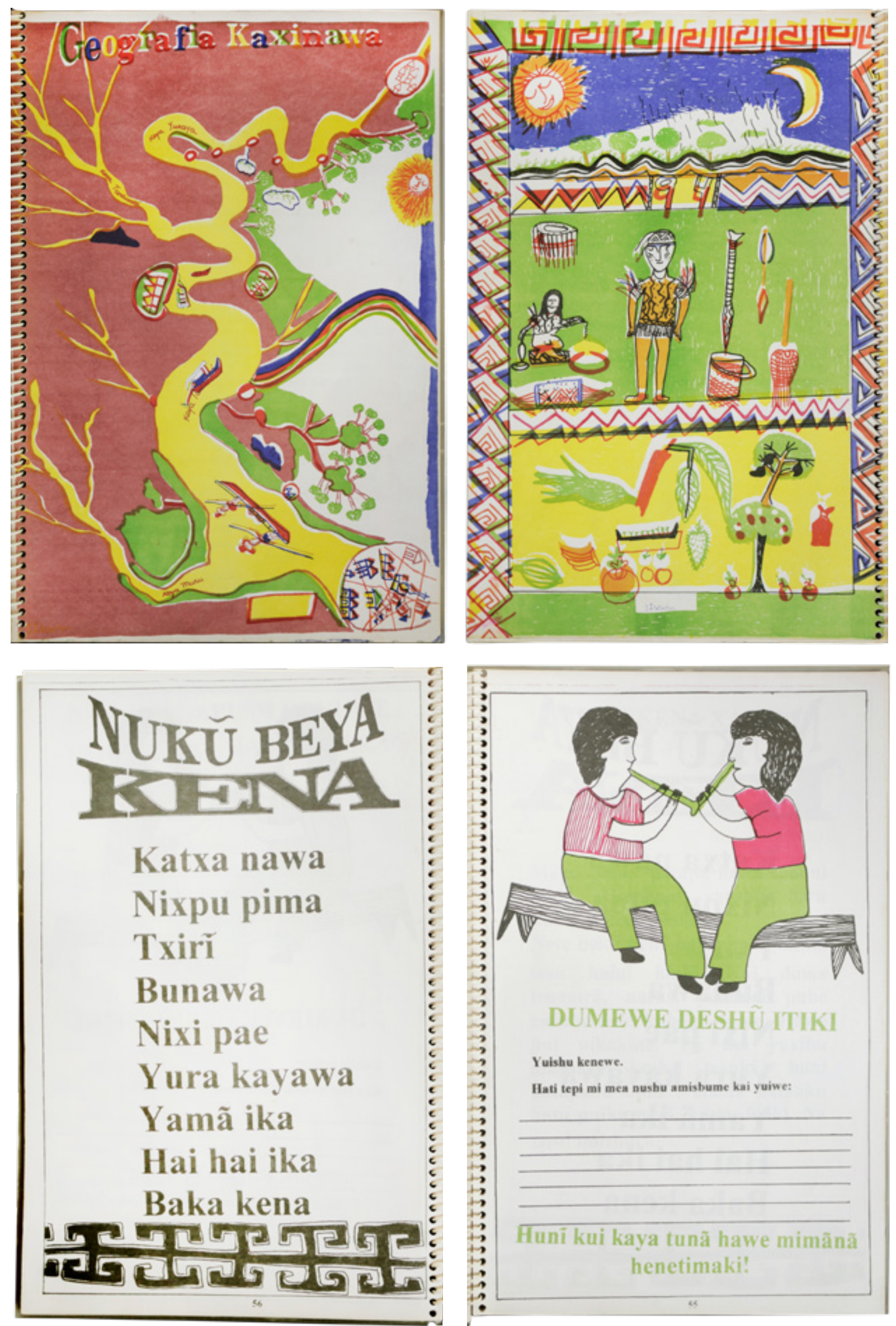

Figuras 148, 149, 150 e 151: Primeira capa, quarta capa e páginas do miolo de Geografia Kaxinawa (1994). Assim como outros materiais de geografia lançados em 1994 e coordenados por Renato Gavazzi, a cartilha faz uso de composições tipográficas interessantes, como também se vê nas figuras 77 e 78, na página 105, e 82, na página 107. A organização dos conteúdos nas páginas não difere muito de outras cartilhas da mesma época. Fonte: Pesquisa de campo, Paiva (2019). 

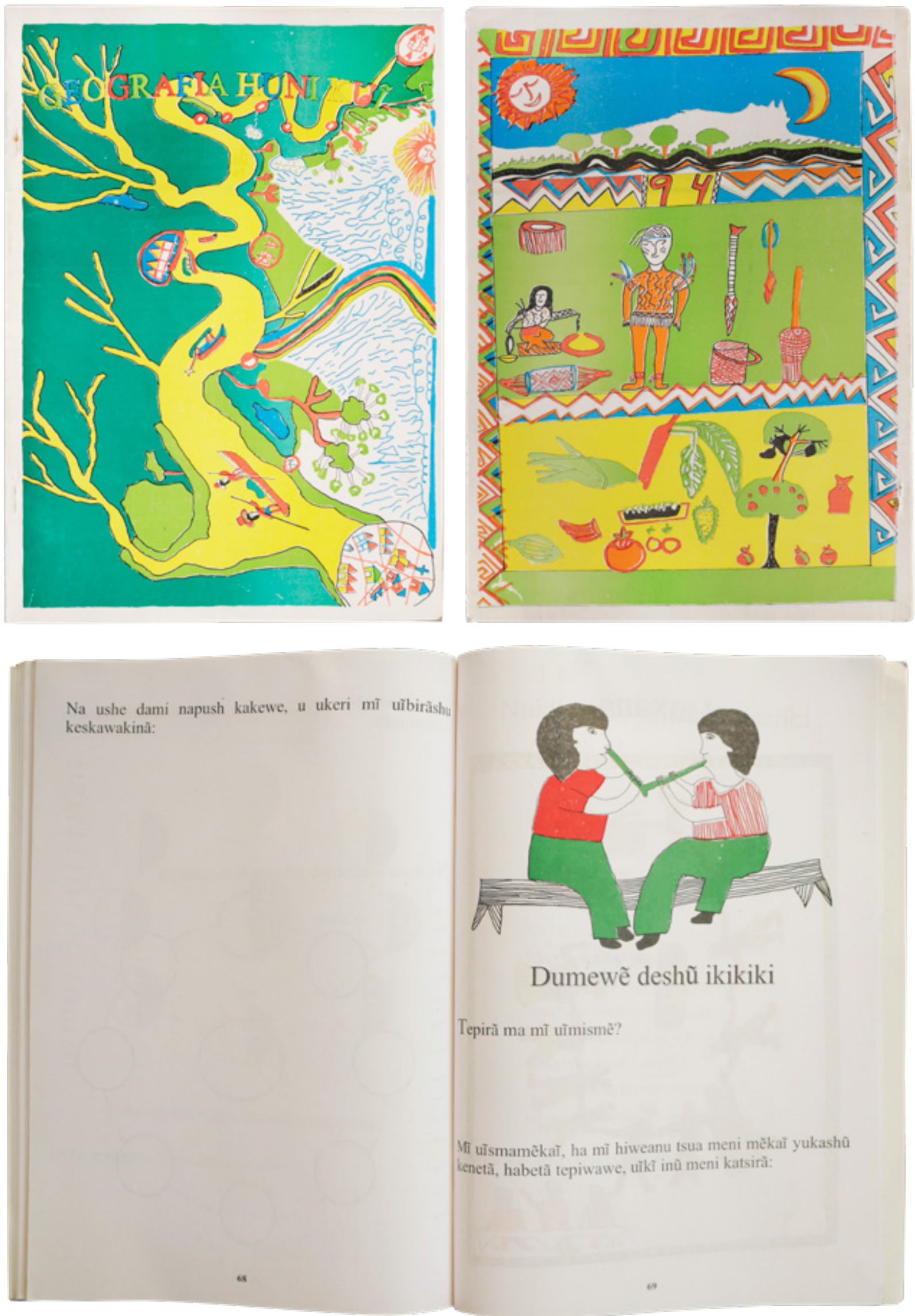

Figuras 152, 153 e 154: Primeira capa, quarta capa e páginas do miolo de Geografia Huni Kuĩ (2001). O conteúdo da segunda edição de material de 1994 é bastante semelhante, e pode-se perceber que o layout foi adaptado para os meios de composição da época. As composições tipográficas vistas na página ao lado não foram reproduzidas. O material foi impresso em gráfica particular em formato A4, enquanto a primeira edição foi impressa na gráfica Kene Hiwe em ofício. Fonte: Pesquisa de campo, Paiva (2019) 

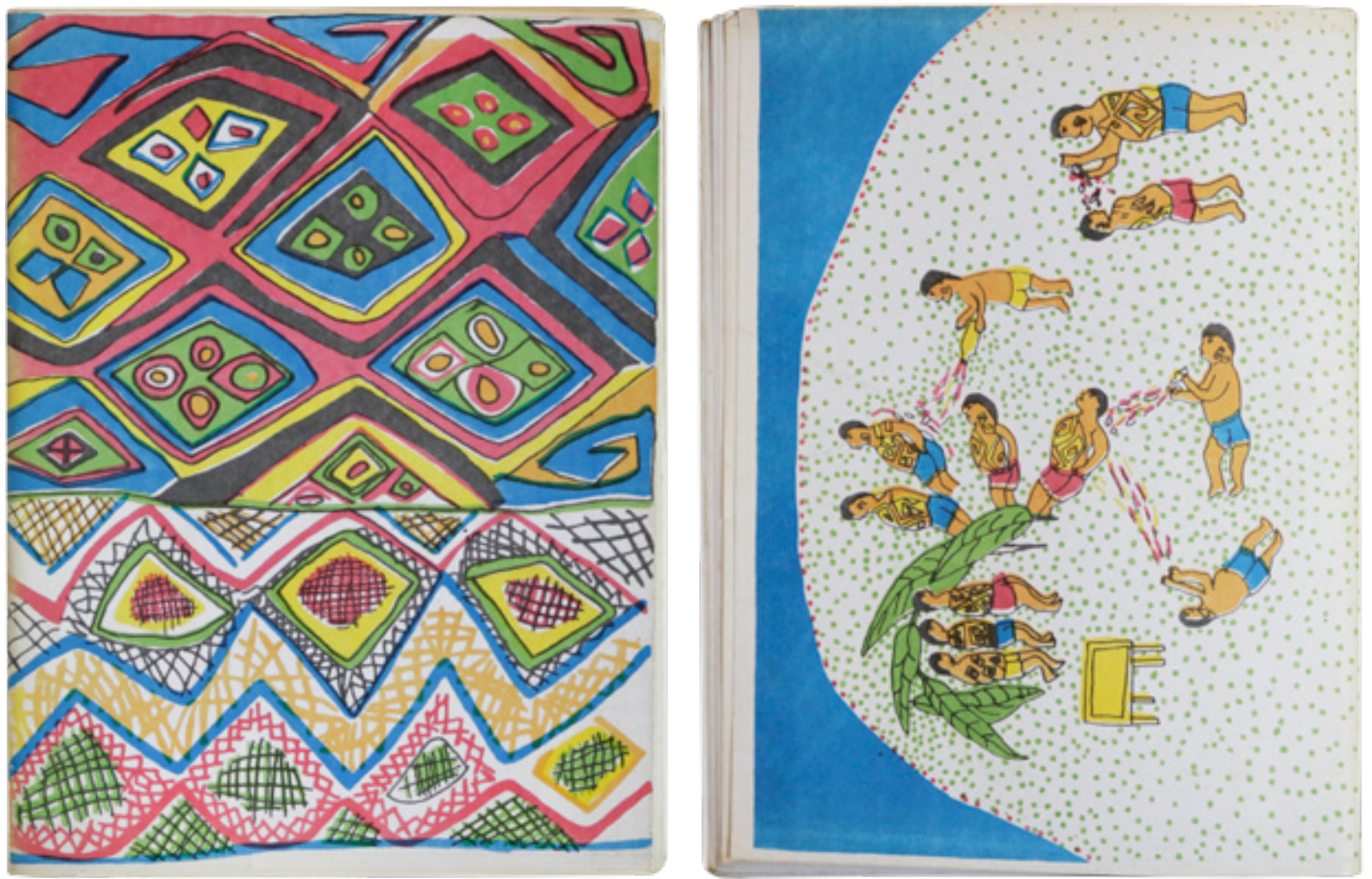

Figuras 155 e 156: áudio, auxiliado pelo professor Paulo Lopes Kaxinawá. Os cantos são aprePrimeira e quarta sentados apenas em hãxta kũ̃, e ao final do volume há um breve texto sobre capas de Nukũ Mimawa

(1995). Assim como outros impressos produzidos pela CPI-AC,

não nenhum tipo de informação verbal na capa. Fonte: Pesquisa de campo, Paiva (2019). a etnia, somente em português, assinado por Marcelo Piedrafita Iglesias. Não há ilustrações no miolo.

Em 2001 uma segunda edição é preparada, com o título Nukũ Mimawa Xarabu, porém, no acervo do CDPI há apenas uma cópia de impressão caseira desta edição, com correções feitas à mão e trechos do texto não finalizados. Não foram encontradas outras cópias com o texto finalizado, o que dá a entender que, apesar de ter-se preparado a reedição, o livro não foi impresso nesse ano, ou que foi feita uma pequena tiragem de impressão caseira. A primeira opção parece mais provável, já que, na ficha catalográfica do mesmo material publicado no ano seguinte, ele é registrado como " $2^{\circ}$ edição". Por tais motivos, optou-se por não analisar esta versão do material.

Em 2002 a segunda edição, com tiragem impressa em gráfica, foi produzida $^{22}$. Na introdução consta a informação de que o livro foi revisado e atualizado. Neste novo projeto, os cantos são acompanhados por fotografias em preto e branco, e há um texto de apresentação em hãxta kuĩ e em português.

Nixi Pae - O Espírito da Floresta, de Isaías Sales Ibã Kaxinawá, publicado em 2006, consiste em um levantamento dos cantos e histórias relativos à "bebida do cipó", ou seja, os rituais de consumo da ayahuasca. Seguindo o modelo de pesquisa de Nukũ Mimawa, os cantos foram levantados através de gravações de áudios com "três velhos Kaxinawá: Romão Sales Tuĩ Kaxinawá, Miguel Macário Iskẽti Kaxinawá e Agostinho Manduca Muru”. O modelo de organização editorial do livro também se repete, com uma apresentação onde o autor explica a pesquisa (dessa vez em português e hãxta kuĩ), um texto de apresentação sobre a etnia Kaxinawá (apenas em português), e um posfácio (também apenas em português) assinado por Maria Luiza pinedo Ochoa e Gleyson de Araújo Teixeira (membros da equipe da CPI-AC). A organização interna dos cantos, entretanto, é um pouco diferente. Em primeiro lugar, os cantos são precedidos pela "História do cipó", 

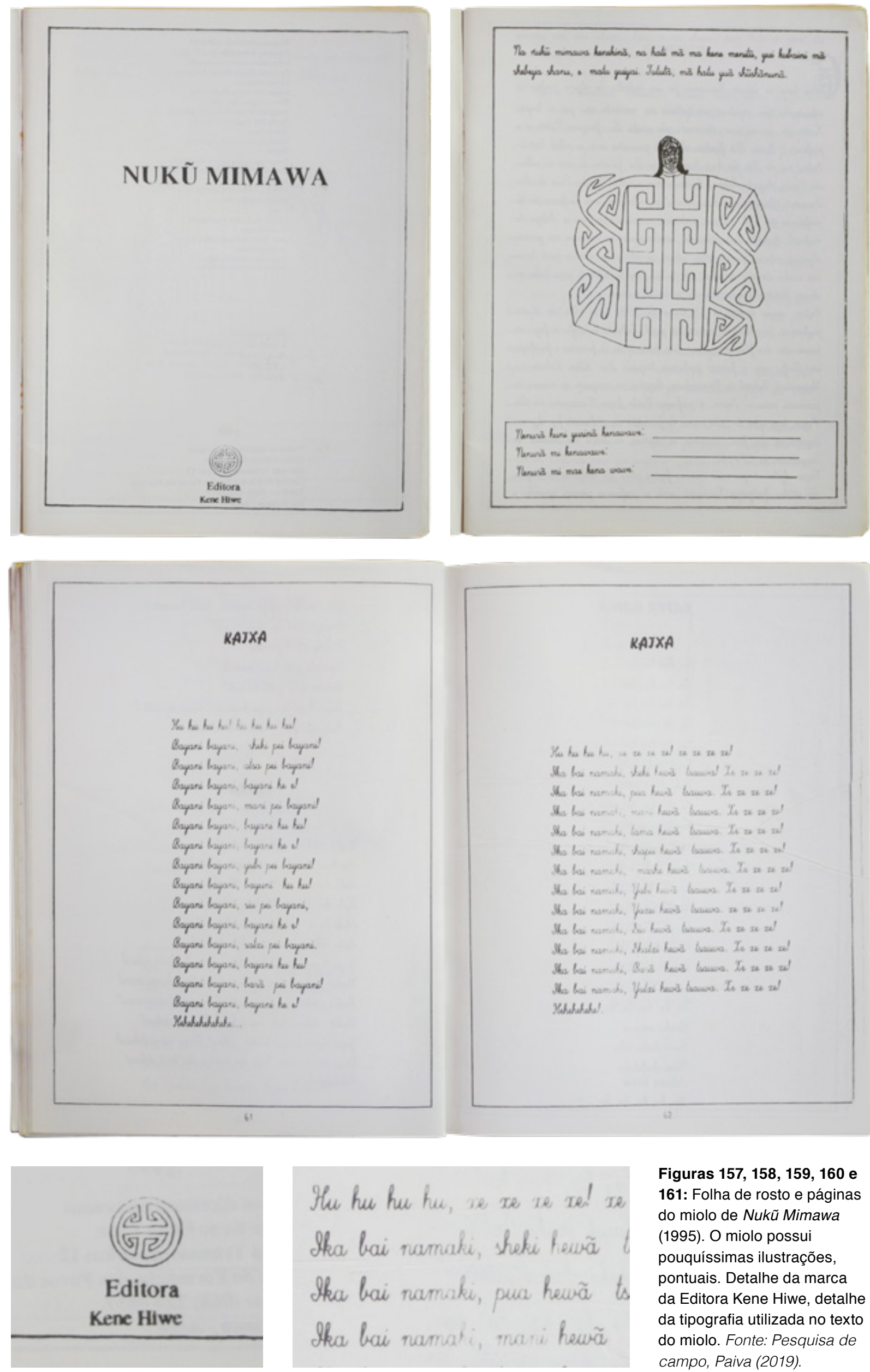

Thu hu hur hue, se to we ve! se tha bai namaki, heki hewã Sha bai namaki, pua hewã to tha bai namati, ma ni hewã
Figuras 157, 158, 159, 160 e 161: Folha de rosto e páginas do miolo de Nukũ Mimawa (1995). O miolo possui pouquíssimas ilustrações, pontuais. Detalhe da marca da Editora Kene Hiwe, detalhe da tipografia utilizada no texto do miolo. Fonte: Pesquisa de campo, Paiva (2019). 
a narrativa kaxinawá que explica a origem do cipó e da aprendizagem de seu preparo para que possa ser bebido. A narrativa é apresentada com ilustrações, impressas a cores, que possuem tanto ou maior destaque quanto o texto escrito. As letras dos cantos acompanham também acompanham uma narrativa ${ }^{23}$, apresentadas na ordem em que foram ouvidas pelo pesquisador e também na ordem em que devem ser cantadas no ritual. Alguns cantos são acompanhados por ilustrações, mas são poucas que se alternam no miolo, e não possuem tanto destaque quanto aquelas que formam a narrativa inicial. Os cantos são reunidos de acordo com seus "cantadores", tal como capítulos. Cada capítulo se inicia com uma pequena descrição e uma fotografia a cores do respectivo cantador.

No ano seguinte o tema é revisitado em Huni Meka - Cantos do Nixi Pae. Segundo consta na apresentação, escrita por Joaquim Paulo Maná Kaxinawá, o livro é resultado de um projeto apoiado pelo Iphan (Instituto do Patrimônio Histórico e Artístico Nacional). Mais uma vez, os cantos são precedidos por uma apresentação que explica a pesquisa, um breve texto sobre a etnia e a "História do Cipó (Huni)" - apresentada em uma versão levemente diferente daquela publicada em Nixi Pae, com algumas alterações na escrita. Além da mudança na escrita, a história é apresentada com menor destaque, ocupando um número menor de páginas, acompanhada por ilustrações pequenas (hierarquicamente inferiores ao texto escrito), algumas das quais são recortes das ilustrações anteriormente publicadas em Nixi Pae - O Espírito da Floresta. Em seguida, os professores pesquisadores são apresentados, com textos escritos por eles mesmos, assim como os txana (cantadores). As apresentações dos txana alternam entre português e hãxta kuĩ (sendo todos os outros textos até então escritos apenas em português). A seguir, a "História das Músicas" é apresentada, em hãxta kuĩ, com um "resumo" em português. Os cantos são numerados e acompanhados pelo crédito do cantor, com uma pequena explicação sobre o momento em que são cantados no ritual ("Músicas para chamar a força do huni quando inicia o ritual do nixi pae", por exemplo). O livro possui uma divisão, de acordo com os 2 CDs de música que o acompanham. Dessa forma, os cantos são separados entre "músicas do disco 1" e "músicas do disco 2". No final do livro, após a apresentação de todos os cantos, há dois textos sobre a pesquisa realizada, assinados por Gustavo Pacheco e Dedê Maia. O livro faz abundante uso de fotografias, que ocupam, via de regra, páginas inteiras. Esta é a publicação mais requintada da Coleção, em termos de acabamento: capa dura, impressão colorida, papel couché para o miolo.

\section{Medicina tradicional}

Plantas Medicinais - Doenças e Curas do Povo Huni Kuĩ, publicado em 2006, é fruto do levantamento iniciado em 1996 por Edson Medeiros Ixã Kaxinawá. A primeira parte do livro é escrita em português, e abrange: a apresentação da pesquisa do pesquisador e do povo Kaxinawá do rio Jordão (com um breve levantamento histórico); o levantamento de "curadores" e pajés que já morreram e dos vivos, organizados de acordo com sua respectiva aldeia; e duas histórias que introduzem o assunto tratado, a "História de origem dos remédios tradicionais" e a "História de origem do povo Huni Kuĩ". Além destes conteúdos, apresentados no começo do livro, nas páginas finais do volume também se encontram uma entrevista com o autor, a relação dos

23 O destaque dado à "história do cipó" e a organização temporal dos contos, com breves inserções entre os mesmos que contam a história do livro e da pesquisa realizada fez com que este livro fosse classificado como livro de leitura nas categorias gerais da Coleção (PAIVA, SOUSA, 2019). 


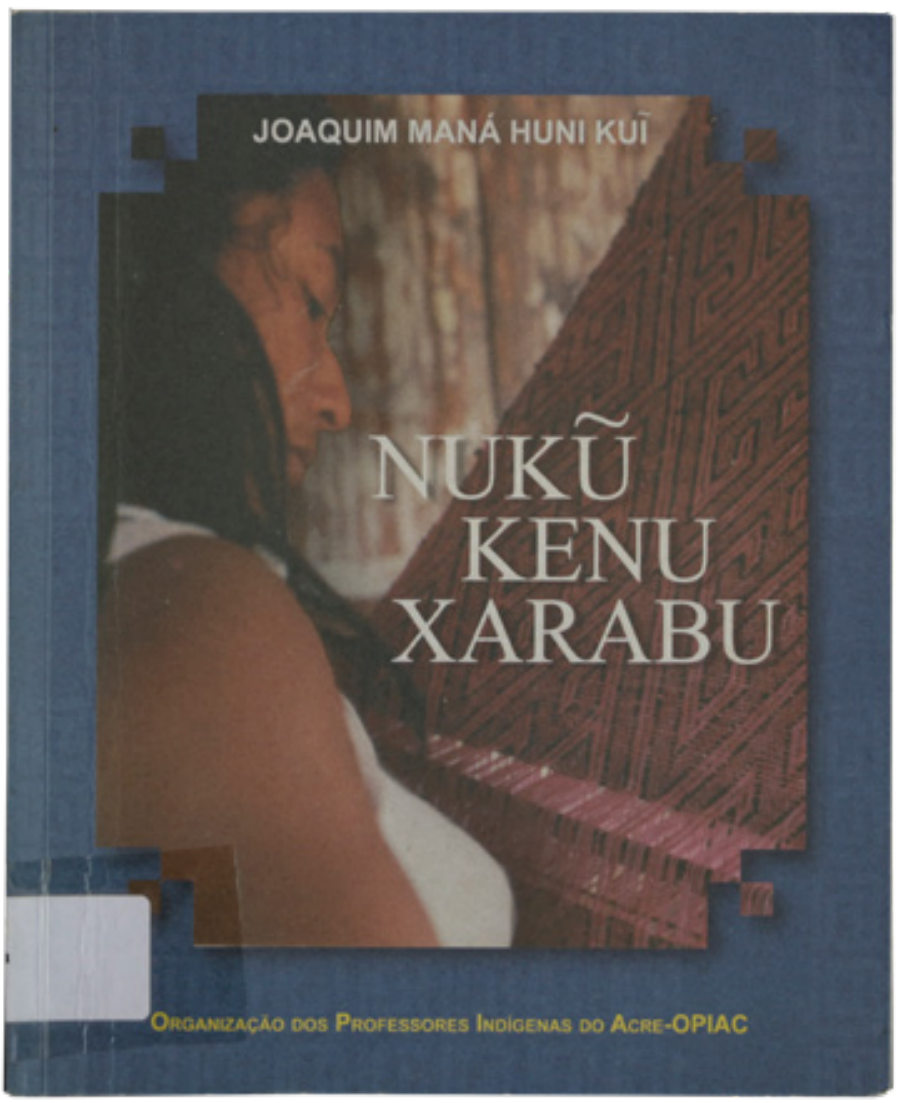

narradores consultados com suas respectivas biografias resumidas, e o posfácio para a primeira e para a segunda edição - nenhum destes textos é acompanhado por ilustrações. A parte principal do livro, contudo, é escrita apenas em hãxta kuĩ e envolve um levantamento das doenças que afligem a população Kaxinawá, assim como das plantas utilizadas para a sua cura ou tratamento, onde encontrá-las (em "terra firme" ou na "beira de igarapés", por exemplo), e como fazer os curativos, quando necessários. O conteúdo verbal é combinado a fotografias e ilustrações, sendo as últimas em maior quantidade. Em 2009 foi produzida uma segunda edição do material - devido a grande demanda pelo livro, a primeira edição foi rapidamente esgotada (TEIXEIRA, 2019) - sem alterações no conteúdo ou layout, a não ser o acréscimo de um posfácio à segunda edição.

\section{Tecelagem e kene}

A primeira pesquisa sobre a tecelagem tradicional kaxinawá, Miyui Mimã Kene - História da Arte de Tecer, foi realizada por Isaías Sales Ibã e publicada em 2000. O livro abrange todo o espectro da produção têxtil, desde as narrativas de origem da tecelagem e dos kene, a colheita e fiação do algodão, o preparo das tintas, o tingimento do algodão, e a tecelagem propriamente dita. Cada sessão vem acompanhada de ilustrações que demonstram os processos descritos. O texto é escrito em hãxta kũ̃, com exceção da apresentação e do sumário, bilíngues.

Em 2006, mais dois livros que tratam do mesmo tema são publicados. Nukũ Kenu Xarabu, extenso levantamento feito por Joaquim Maná, abrange a classificação dos tipos de kene diferentes produzidos na tecelagem e utilizados na pintura corporal. O livro, escrito em hãxta kuĩ com apresentação e dedicatória em português, é organizado em três partes. A primeira trata das origens dos kene e da tecelagem kaxinawá, e apresenta as mestres do kene entrevistadas. A segunda dedica-se aos kene utilizados na pintura corporal, classificados "por gênero e idade, e as músicas a elas associadas". A terceira parte contém a apresentação e classificação dos kene utilizados na tecelagem.
Figura 162: Primeira capa de Nukũ Kenu Xarabu (2006). Fonte: Pesquisa de campo, Paiva (2019). 


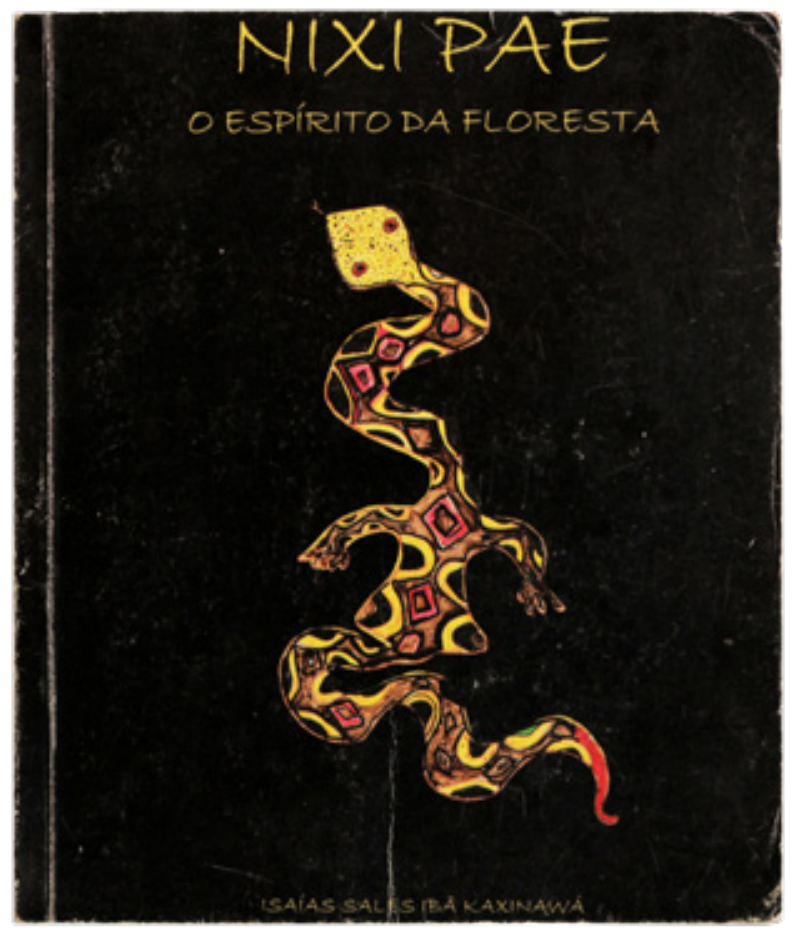

ou encanto de jibóia.

a sua casa, entrou no quarto e ficou dentro de 1 assim pra ele:

1 avisar para o meu pai e a minha mãe.

isou assim:

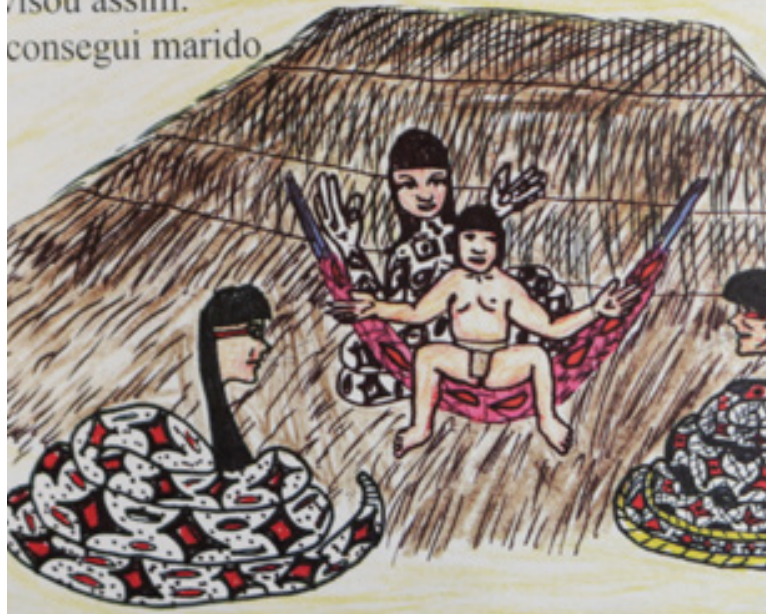

entes dela gostaram dele. Ele morou com ela

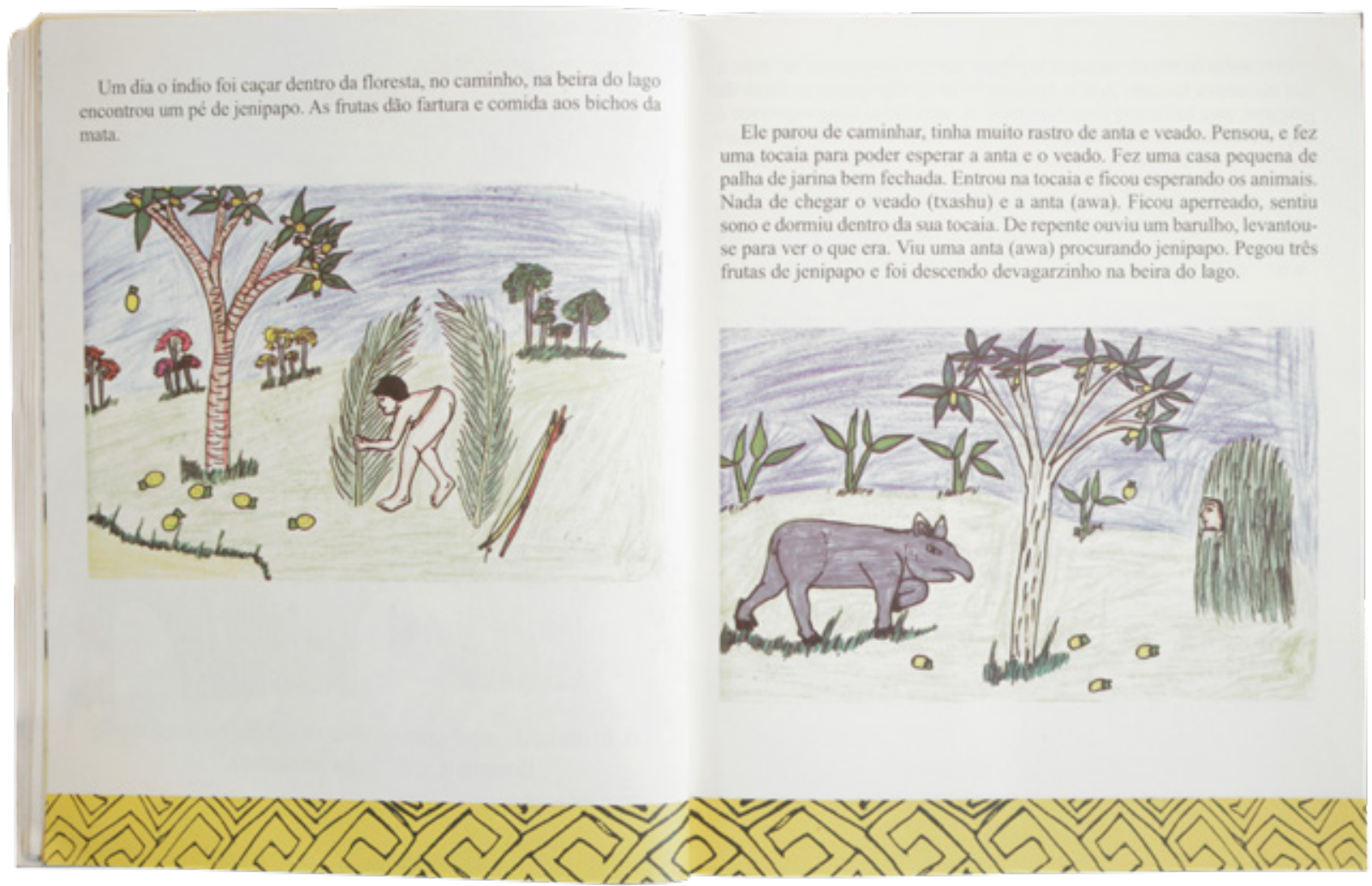

Figura 163: Primeira capa de Nixi Pae - O

Espírito da Floresta (2006). Fonte: Pesquisa de campo, Paiva (2019).
Figura 164: Detalhe de ilustração do miolo de Nixi Pae - O Espírito da Floresta (2006). A mulher-giboia retratada na ilustração foi utilizada novamente no layout de Huni Meka (2007), como se vê na figura 166, na página ao lado. Fonte: Pesquisa de campo, Paiva (2019).
Figura 165: Página do miolo de Nixi Pae - O Espírito da Floresta (2006). A narrativa que explica a origem do cipó (ayahuasca) é ricamente acompanhada por ilustrações. Fonte: Pesquisa de campo, Paiva (2019). 


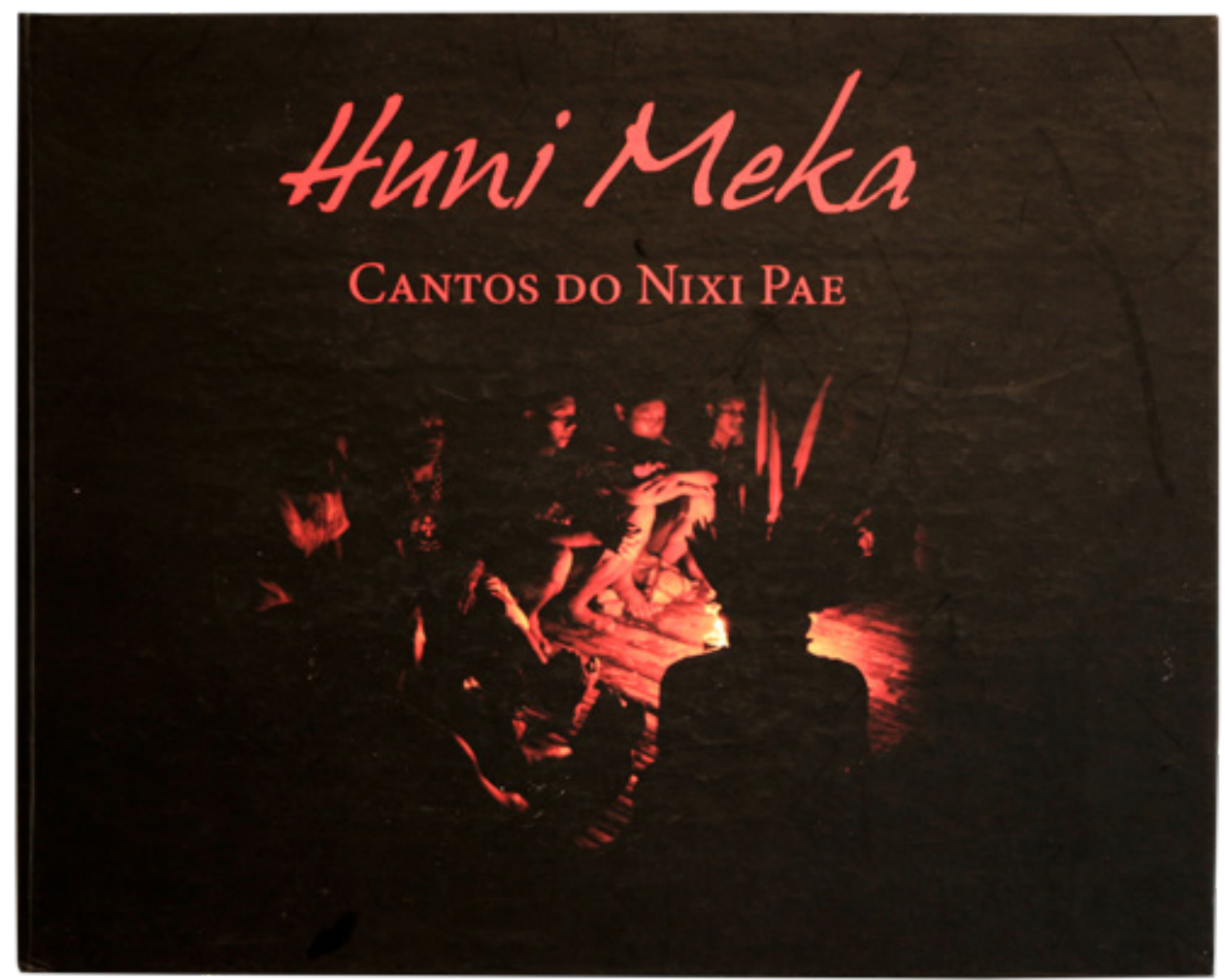

Figuras 166, $167 \mathrm{e}$

168: Primeira capa e páginas do miolo de Huni Meka - Cantos do Nixi Pae (2007). Este é o único livro em capa dura da Coleção. Fonte: Pesquisa de campo, Paiva (2019).
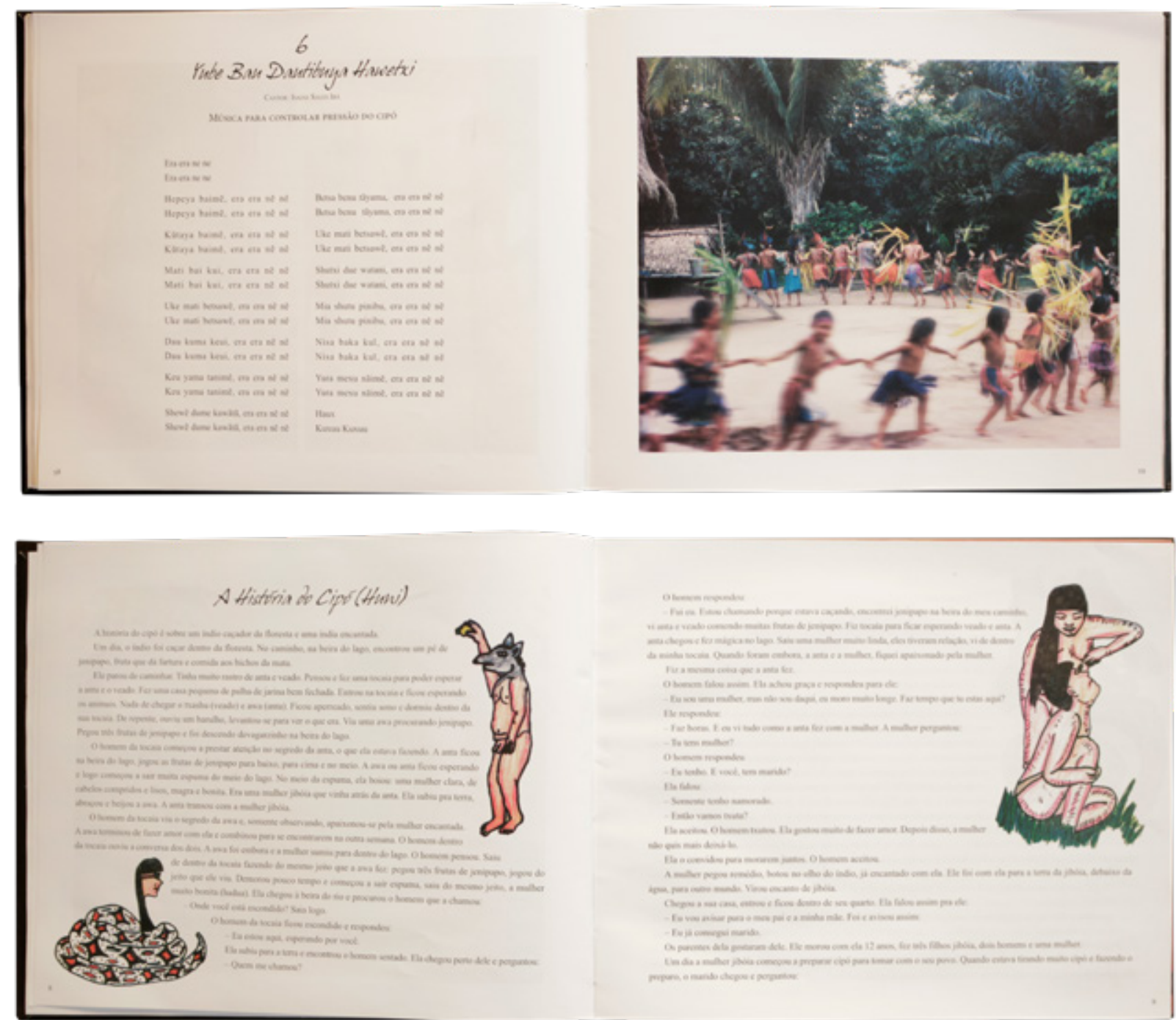

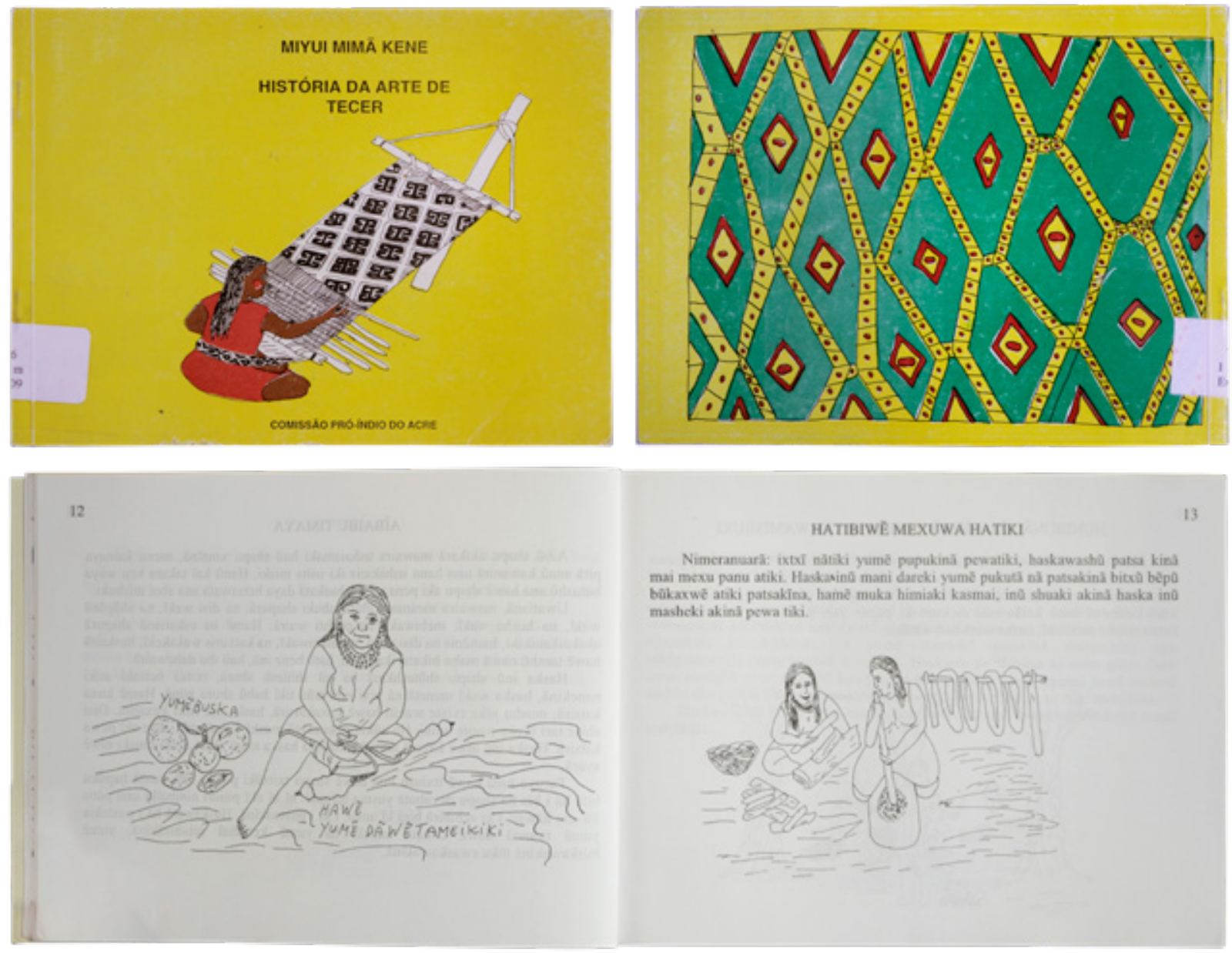

Figuras 169, 170 e 171: Primeira capa, quarta capa e páginas do miolo de Miyumi Mimã Kene História da Arte de Tecer (2000). Fonte: Pesquisa de campo, Paiva (2019).
A Arte do Kene, livro mais sucinto também publicado em 2006, trata não só da origem e das técnicas de tecelagem, como também de um breve levantamento da cultura material Kaxinawá. O livro foi escrito por "Agostinho Muru e professores indígenas das terras Kaxinawá do Rio Breu e Rio Jordão". Segundo Dedê Maia (MAIA, 2019) este livro foi inicialmente pensado como um grande volume, que registraria a produção de mantas em tecelagem realizadas em um projeto específico da CPI-AC em parceria com a iniciativa privada. Contudo, devido a problemas de financiamento, foi necessário simplificar o projeto, e decidiu-se pela produção do pequeno volume, com cerca de 40 páginas grampeadas.

\section{Manejo florestal}

Ũ̃ Bena, publicado em 2006, trata do manejo de quelônios (tracajás, tartarugas e jabutis) nas TIs kaxinawá. O livro, produzido nas formações de agentes agroflorestais indígenas, parte da preocupação com "a escassez de alguns recursos naturais em nossa região", conforme é apresentado em sua introdução, o único texto bilíngue do livro. O conteúdo abrange histórias tradicionais a respeito desses animais, assim como técnicas para sua criação em cativeiro (como realizar a preparação de barragens, coletar os ovos, a alimentação dos animais e seu repovoamento nos rios, igarapés e lagos) e modelos para a regulamentação dos criadouros junto ao IBAMA (Instituto Brasileiro de Meio Ambiente). Ilustrações acompanham as narrativas tradicionais da primeira parte do livro, assim como os conteúdos mais técni$\cos$, que também contém registros fotográficos ${ }^{24}$. 

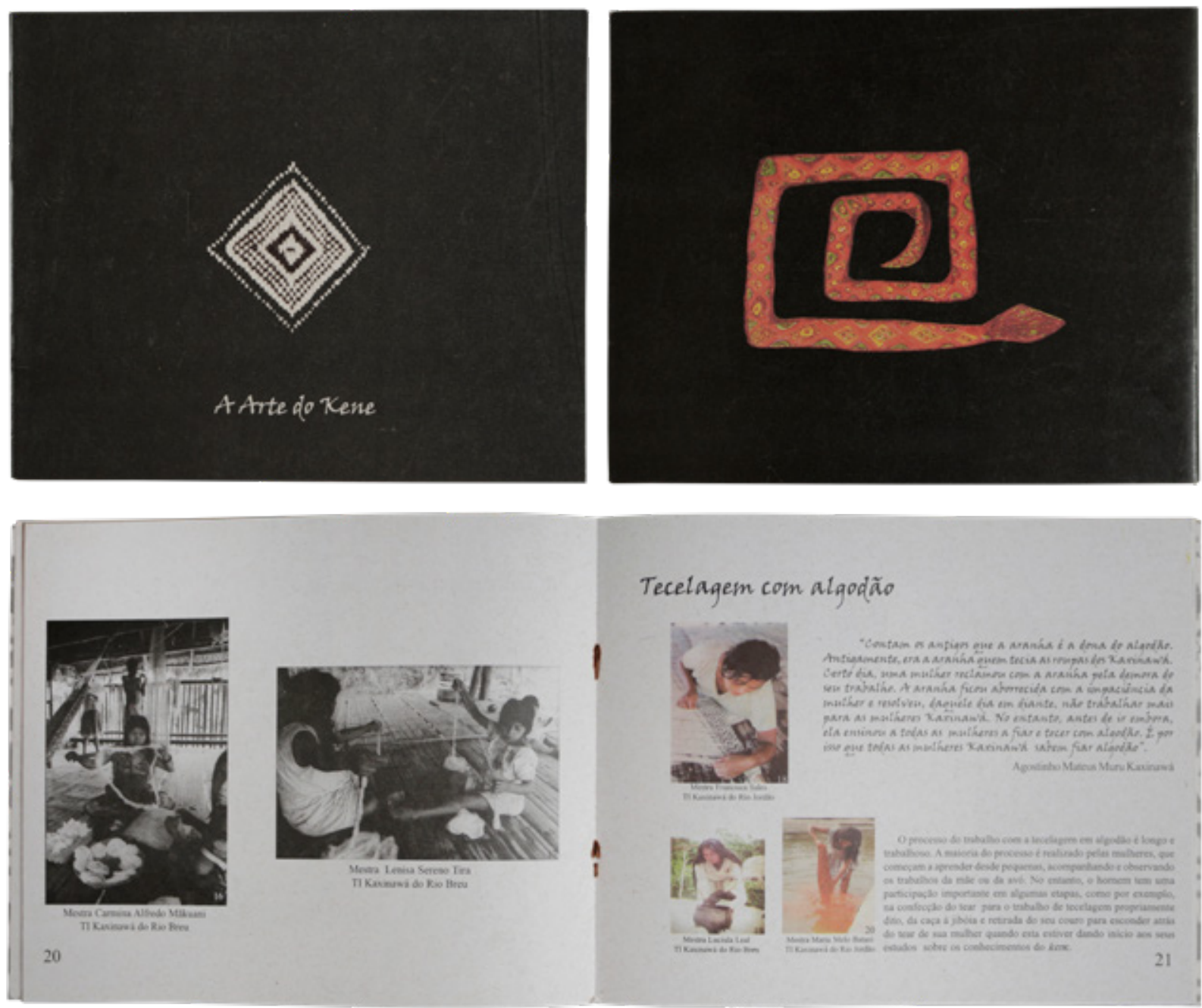

\section{Características Materiais}

Os formatos dos livros analisados variam, especialmente a partir dos anos 2000, quando deixaram de ser produzidos na gráfica interna da CPI-AC, como se pode ver na tabela 4 (Shenipabu Myiui - História dos Antigos é uma exceção, pois não foi impresso na gráfica interna). Conforme explicitado no Capítulo 3 desta dissertação, a impressora da gráfica da CPI-AC só imprimia até o formato, motivo pelo qual alguns livros foram impressos em "ofício", ou em variações deste formato.

Mesmo as apostilas que não foram impressas na gráfica interna adotam formatos um pouco maiores, provavelmente porque seus projetos gráficos são os mesmos, e adotar um formato semelhante facilita o processo de adaptação dos layouts.

As características dos livros variam, também, de acordo com a verba disponível para sua impressão e, segundo as entrevistas realizadas com alguns dos designers responsáveis pelos projetos, o formato, o papel, o tipo de impressão e a encadernação eram definidos pela equipe da CPI-AC.

Mesmo com as restrições financeiras, percebe-se uma preocupação em fazer livros coloridos, e utilizar papeis mais resistentes para as capas, favorecendo a durabilidade do material. Dava-se, também, preferências por formatos menores, que pudessem ser mais facilmente transportados e armazenados nas longas viagens para as TI (SENA, 2019). Supõe-se que tais formatos reduzidos também influenciavam no barateamento das impressões, especialmente para os livros impressos em gráficas comerciais.
Figuras 172,173 e 174: Primeira capa, quarta capa e páginas do miolo de A Arte do Kene (2006), detalhes da mancha gráfica do miolo. Fonte: Pesquisa de campo, Paiva (2019). 


\begin{tabular}{|c|c|c|c|c|c|c|c|}
\hline \multicolumn{8}{|c|}{ IMPRESSÃO } \\
\hline & TítULO & $\begin{array}{l}\text { FORMATO EM } \\
\text { CM (L X A) }\end{array}$ & $\begin{array}{l}\text { ENCADER- } \\
\text { NAÇÃO }\end{array}$ & CAPA & MIOLO & CAPA & MIOLO \\
\hline & CARTILHA KAXINAWÁ & $21,6 \times 35,6$ & & & & & OFFSET \\
\hline 1. & HÃTXA HUNI KUĨ (1989) & (OFÍCIO) & GRAMPO & POLI. & POLI. & CARTÃO (230g) & (90g) \\
\hline \multirow[t]{2}{*}{2.} & KENE (1994) & - & - & - & - & - & - \\
\hline & & $21,6 \times 35,6$ & & & & & OFFSET \\
\hline \multirow[t]{2}{*}{3.} & GEOGRAFIA KAXINAWÁ (1994) & (OFÍCIO) & GRAMPO & POLI. & POLI. & CARTÃO (230g) & $(90 \mathrm{~g})$ \\
\hline & SHENIPABU MIYUI - HISTÓRIA DOS & & & & & CARTÃO (230g) & OFFSET \\
\hline \multirow[t]{2}{*}{4.} & ANTIGOS (1995) & $15,5 \times 22,5$ & COLADA & POLI. & POLI. & LAM. BOPP & $(90 \mathrm{~g})$ \\
\hline & & & GRAMPO & & & & OFFSET \\
\hline \multirow[t]{2}{*}{5.} & NUKŨ MIMAWA (1995) & $16,5 \times 21,7$ & CANOA & POLI. & MONO. & CARTÃO (230g) & $(90 \mathrm{~g})$ \\
\hline & & & & & & & OFFSET \\
\hline \multirow[t]{2}{*}{6.} & YUMEBU MIYUI - MAE BI KENA (1997) & $21 \times 28,7$ & - & POLI. & POLI. & CARTÃO (230g) & $(90 \mathrm{~g})$ \\
\hline & & & & & & & OFFSET \\
\hline \multirow[t]{2}{*}{7.} & KENE $2^{\circ}$ ED (2000) & $21 \times 29$ & GRAMPO & POLI. & POLI. & COUCHE (230g) & $(75 G)$ \\
\hline & MIYUI MIMÃ KENE - HISTÓRIA DA ARTE & & GRAMPO & & & & OFFSET \\
\hline \multirow[t]{2}{*}{8.} & DE TECER (2000) & $20 \times 14,7$ & CANOA & POLI. & MONO. & COUCHE (230g) & $(75 g)$ \\
\hline & & & & & & & OFFSET \\
\hline \multirow[t]{2}{*}{9.} & GEOGRAFIA HUNI KUĨ 2 ED. (2001) & $21 \times 29$ & GRAMPO & POLI. & POLI. & COUCHE (230g) & $(75 g)$ \\
\hline & & & & & & CARTÃO (230g) & OFFSET \\
\hline \multirow[t]{2}{*}{10.} & NUKŨ MIMAWA XARABU $2^{\circ}$ ED. (2002) & $18 \times 21,5$ & COLADA & POLI. & MONO. & $C \backslash$ LAM. BOPP & $(90 \mathrm{~g})$ \\
\hline & NIXI PAE- O ESPÍRITO & & & & & CARTÃO (230g) & PÓLEN \\
\hline \multirow[t]{2}{*}{11.} & DA FLORESTA (2006) & $17,5 \times 21$ & COLADA & POLI. & POLI. & LAM. BOPP & $(90 \mathrm{~g})$ \\
\hline & & & & & & RECl. (230g) C $\backslash$ & RECl. \\
\hline \multirow[t]{2}{*}{12.} & NUKU KENU XARABU (2006) & $18 \times 22$ & COLADA & POLI. & POLI. & LAM. BOPP & $(90 \mathrm{~g})$ \\
\hline & PLANTAS MEDICINAIS - DOENÇAS E & & & & & RECl. (230g) & RECl. \\
\hline \multirow[t]{2}{*}{13.} & CURAS DO POVO HUNI KUĨ (2006) & $17 \times 21$ & COLADA & POLI. & POLI. & LAM. BRILHO & $(90 \mathrm{~g})$ \\
\hline & & & GRAMPO & & & RECl. (230g) & RECl. \\
\hline \multirow[t]{2}{*}{14.} & A ARTE DO KENE (2006) & $21 \times 17$ & CANOA & POLI. & POLI. & LAM. BOPP & $(90 \mathrm{~g})$ \\
\hline & & & & & & CARTÃO (230g) & COUCHE \\
\hline \multirow[t]{2}{*}{15.} & UĨ BENA (2006) & $20,5 \times 20$ & COLADA & POLI. & POLI. & LAM. BOPP & (90G) \\
\hline & & & & & & & COUCHE \\
\hline \multirow[t]{2}{*}{16.} & HUNI MEKA (2007) & $26,5 \times 21,5$ & COLADA & POLI. & POLI. & CAPA DURA & $(90 \mathrm{~g})$ \\
\hline & PLANTAS MEDICINAIS - DOENÇAS E & & & & & RECl. (230g) & RECl. \\
\hline 17. & CURAS DO POVO HUNI KUĨ $2^{\circ}$ ED. (2009) & $17 \times 21$ & COLADA & POLI. & POLI. & LAM. BOPP & $(90 \mathrm{~g})$ \\
\hline
\end{tabular}

POLI = POLICROMÁTICA

MONO = MONOCROMÁTICA
LAM. = LAMINÇÃO

RECI. = RECICLADO

Tabela 4: Características materiais dos livros de autores kaxinawá que fazem parte da Coleção Autoria Indígena.Os valores das gramaturas dos papeis são aproximados. Esta tabela não inclui a edição de 2001 de Nukũ Mimawa Xarabu, já que não foram encontrados exemplares finalizados desta edição no acervo, conforme previamente justificado.

Fonte: Pesquisa de campo, Paiva (2019). 
1.

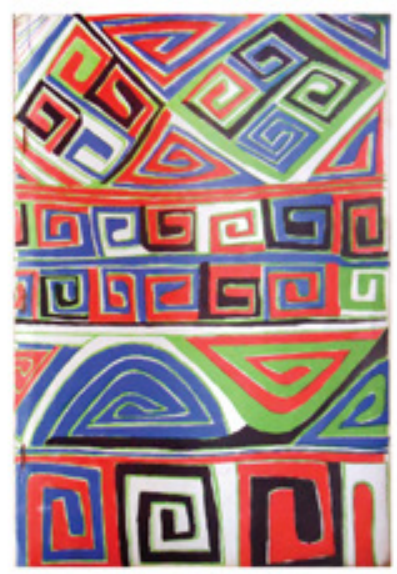

3.

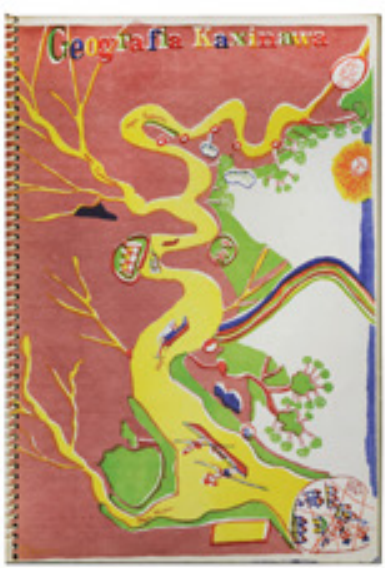

4.

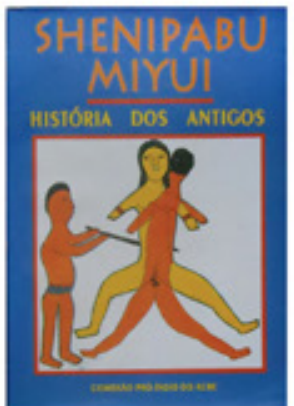

5.

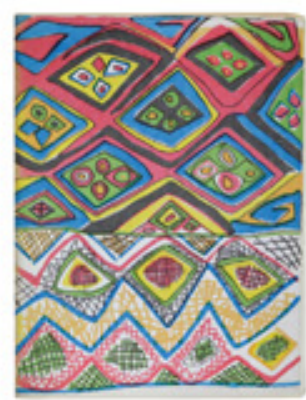

6.

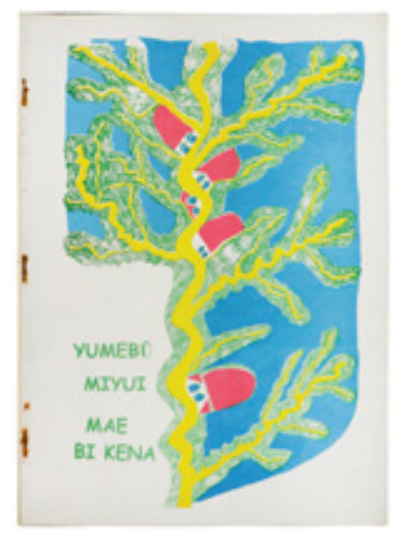

7.

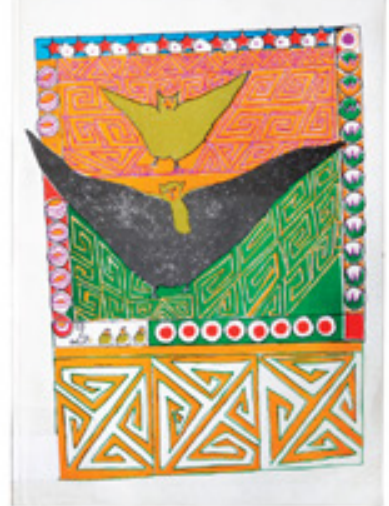

11.

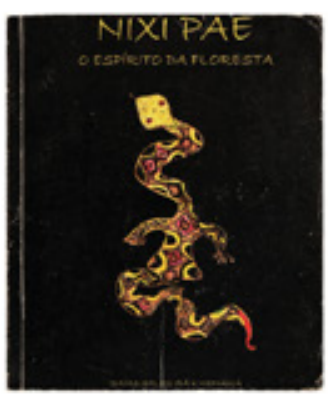

8.

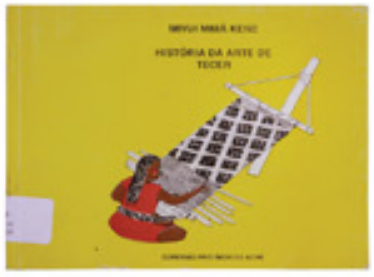

12.

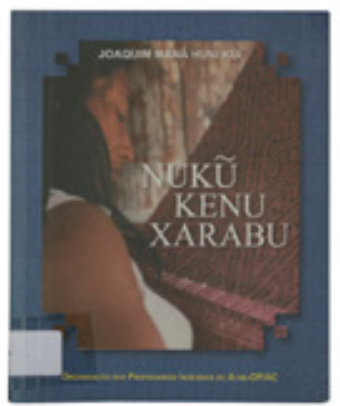

9.

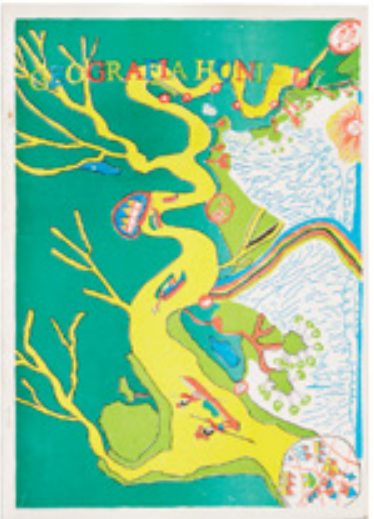

10.

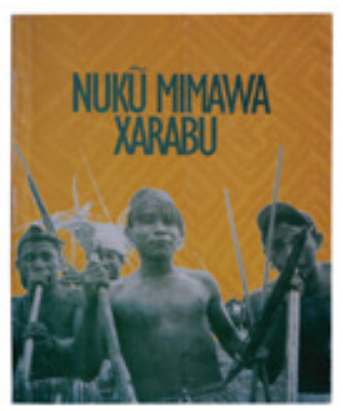

15.

14.

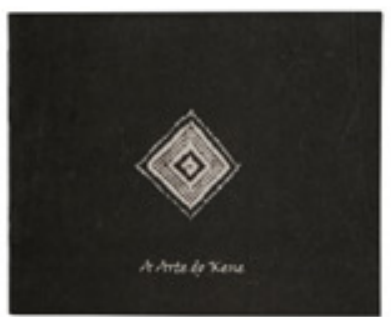

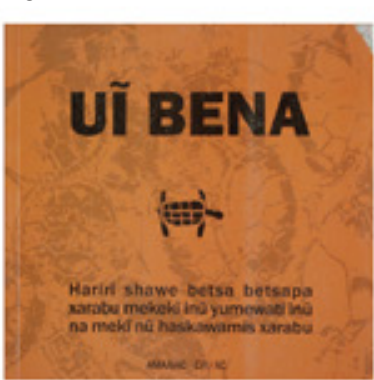

13.

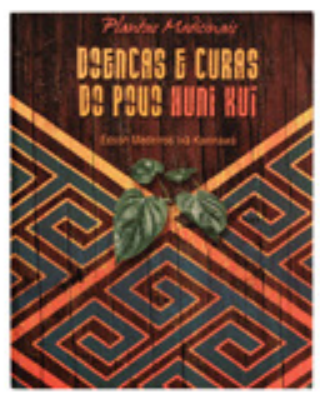

16.

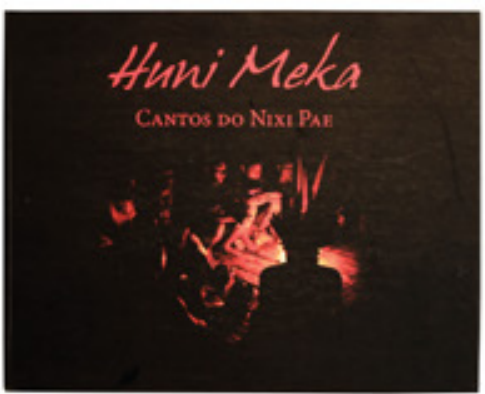

Figura 175: Primeiras capas dos livros de autoria exclusivmente kaxinawá que fazem parte da Coleção Autoria Indígena. As capas foram dimensionadas proporcionalmente de acordo com as medidas reais dos impressos. Os livros foram numerados de acordo com a tabela 5, na página ao lado. O livro número 2 não foi encontrado em acervo, portanto não há registro fotográfico de sua capa. Fonte: Pesquisa de campo, Paiva (2019). 


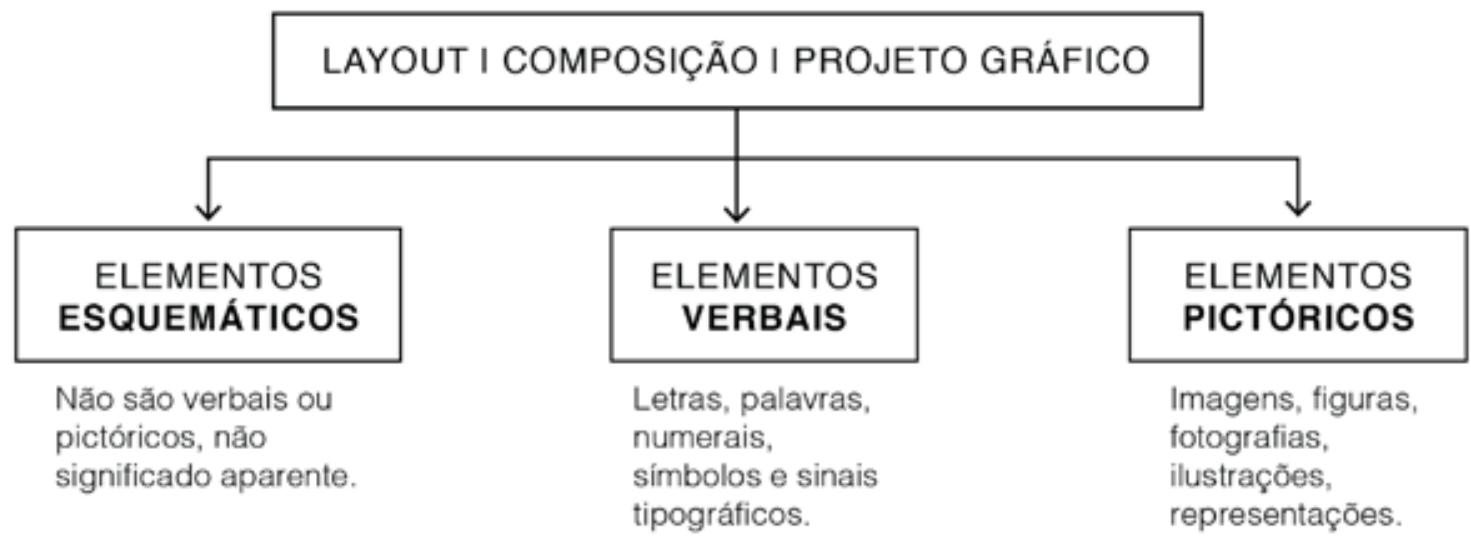

Figura 176: Esquema de classificação para elementos gráficos. Fonte: Adaptação da autora a partir de Twyman (1979)

\subsection{Mapeamento dos elementos gráficos}

Twyman (1979) classifica os elementos que compõem um projeto gráfico em três categorias: esquemáticos, verbais e pictóricos. Os elementos verbais são aqueles que apresentam letras, palavras, numerais e símbolos tipográficos diversos. Os elementos pictóricos são as imagens, fotografias, ilustrações. Já os elementos esquemáticos são aqueles que não se enquadram nos grupos anteriores, não apresentando relação ou significado aparente enquanto elemento verbal ou imagem.

A distinção entre elementos pictóricos e esquemáticos é significante no contexto desta pesquisa tento em vista que os kene, apesar não apresentarem relação direta com representações figurativas, possuem significados diversos e específicos na cultura kaxinawá.

A escolha do método se deu devido à sua praticidade. Enquanto outros autores propõem divisões mais detalhadas para os elementos de determinado laytout ${ }^{25}$, as categorias propostas por Twyman (Ibid.) permitem uma abordagem mais sucinta, ainda que satisfatoriamente completa, para o mapeamento gráfico dos livros analisados. Tal abordagem é considerada adequada para a quantidade de livros do recorte feito, tendo em vista que o objetivo desta análise está mais direcionado à compreensão das relações existentes entre as manifestações visuais e materiais tradicionais da cultura Kaxinawá do que ao exame minucioso das técnicas e elementos gráficos utilizados na composição dos layouts ${ }^{26}$.

Dessa forma, os elementos gráficos dos livros são tratados em conjunto, de acordo com cada categoria, e buscou-se compreendê-los em termos de pluralidade (ou seja, o que é comum a várias publicações) e singularidade (o que se destaca, fugindo aos padrões determinados).

\section{Elementos esquemáticos}

Os elementos esquemáticos não são muito utilizados na composição dos projetos gráficos dos livros analisados: os elementos verbais e pictóricos possuem muito mais destaque. Aparecem em maior quantidade nas cartilhas, como linhas utilizadas para delimitar os espaços específicos destinados às respostas dos exercícios.

25 Como o método proposto por Villas-Boas (2009), entre outros.

26 Que demandaria, por exemplo, procedimentos para a definição específica das fontes tipográficas utilizadas, a medição exata de margens e entrelinhas, a classificação de estilos de títulos e subtítulos etc. Esta também é uma análise interessantíssima, porém não é o que se intenciona realizar neste momento. 
Os Kaxinawá do Acre e os livros da Coleção Autoria Indígena: uma análise em design editorial

\begin{tabular}{|c|c|c|c|c|c|c|c|}
\hline \multirow[b]{3}{*}{ ANO } & \multirow[b]{3}{*}{ TítULO } & \multicolumn{5}{|c|}{ ELEMENTOS } & \\
\hline & & \multicolumn{2}{|c|}{ ESQUEMÁTICOS } & \multicolumn{2}{|c|}{ VERBAIS } & $\underset{\text { PICTÓRICOS }}{|c|}$ & \\
\hline & & $1^{\circ} \mathrm{CAPA}$ & MIOLO & $1^{\circ} \mathrm{CAPA}$ & MIOLO & $1^{\circ} \mathrm{CAPA}$ & MIOLO \\
\hline 1989 & $\begin{array}{l}\text { CARTILHA KAXINAWÁ - } \\
\text { HÃTXA HUNI KUĨ }\end{array}$ & - & $x$ & - & $x$ & IL. & IL. \\
\hline 1994 & KENE & - & - & - & - & - & - \\
\hline 1994 & GEOGRAFIA KAXINAWÁ & - & $x$ & $x$ & $x$ & IL. & IL. \\
\hline 1995 & $\begin{array}{l}\text { SHENIPABU MIYUI - HISTÓRIAS } \\
\text { DOS ANTIGOS }\end{array}$ & $x$ & $x$ & $x$ & $x$ & IL. & $\begin{array}{l}\text { IL. } \\
\text { FT. }\end{array}$ \\
\hline 1995 & NUKŨ MIMAWA & - & $x$ & - & $x$ & IL. & - \\
\hline 1997 & YUMEBŨ MIYUI - MAE BI KENA & - & - & $x$ & $x$ & IL. & IL. \\
\hline 2000 & KENE $\left(2^{\circ}\right.$ ED.) & - & - & - & $x$ & IL. & IL. \\
\hline 2000 & $\begin{array}{l}\text { MIYUI MIMÃ KENE - } \\
\text { HISTÓRIA DA ARTE DE TECER }\end{array}$ & - & - & $x$ & $x$ & IL. & IL. \\
\hline 2001 & $\begin{array}{l}\text { GEOGRAFIA HUNI } \\
\text { KUI ( } 2^{\circ} \text { ED.) }\end{array}$ & - & $x$ & $x$ & $x$ & IL. & IL. \\
\hline 2002 & NUKŪ MIMAWA XARABU ( $2^{\circ}$ ED.) & - & - & $x$ & $x$ & FT. & FT. \\
\hline 2006 & $\begin{array}{l}\text { NIXI PAE - O ESPÍRITO } \\
\text { DA FLORESTA }\end{array}$ & - & - & $x$ & $x$ & IL. & $\begin{array}{l}\text { IL. } \\
\text { FT. }\end{array}$ \\
\hline 2006 & NUKU KENU XARABU & - & - & $x$ & $x$ & FT. & FT. \\
\hline 2006 & $\begin{array}{l}\text { PLANTAS MEDICINAIS - DOENÇAS E } \\
\text { CURAS DO POVO HUNI KUĨ }\end{array}$ & - & - & $x$ & $x$ & FT. & $\begin{array}{l}\text { IL. } \\
\text { FT. }\end{array}$ \\
\hline 2006 & A ARTE DO KENE & - & - & $x$ & $x$ & IL. & $\begin{array}{l}\text { IL. } \\
\text { FT. }\end{array}$ \\
\hline 2006 & UĨ BENA & - & - & $x$ & $x$ & $\begin{array}{l}\text { IL. } \\
\text { FT. }\end{array}$ & $\begin{array}{l}\text { IL. } \\
\text { FT. }\end{array}$ \\
\hline 2007 & HUNI MEKA & - & - & $x$ & $x$ & FT. & $\begin{array}{l}\text { IL. } \\
\text { FT. }\end{array}$ \\
\hline 2009 & $\begin{array}{l}\text { PLANTAS MEDICINAIS - DOENÇAS E } \\
\text { CURAS DO POVO HUNI KUĨ (2 ED.) }\end{array}$ & - & - & $x$ & $x$ & FT. & $\begin{array}{l}\text { IL. } \\
\text { FT. }\end{array}$ \\
\hline
\end{tabular}

$$
\begin{array}{ll}
X=\text { PRESENÇA DO ELEMENTO EM QUESTÃO } & \text { FT. = FOTOGRAFIAS } \\
\text { - = AUSÊNCIA DO ELEMENTO EM QUESTÃO } & \text { IL. = ILUSTRAÇÕES }
\end{array}
$$

Tabela 5: Presença de elementos esquemáticos, verbais e pictóricos nas capas e miolos livros de autores kaxinawá que fazem parte da Coleção Autoria Indígena. Fonte: Pesquisa de campo, Paiva (2019). 
Figuras 177 e 178: Exemplos de elementos esquemáticos (grifados em amarelo) em páginas

do miolo de Cartilha Kaxinawa - Hãxta Huni Kuĩ (1989), à esquerda, e de Geografia Kaxinawa (1994), à direita. Fonte:

Pesquisa de campo. Paiva (2019).

Figuras 179 e 180: Exemplos de elementos esquemáticos (grifados em amarelo) em páginas do miolo de Nukũ Mimawa (1995), à esquerda, e de Kene $2^{\circ} \mathrm{ed}$. (2001), à direita.

Fonte: Pesquisa de campo, Paiva (2019).

Figuras 181 e 182 Exemplos de elementos esquemáticos em páginas do miolo (grifados em amarelo), à esquerda, e na capa (grifados em branco), à direita, de Shenipabu Miyui - História dos Antigos (1996). Fonte: Pesquisa de campo Paiva (2019).
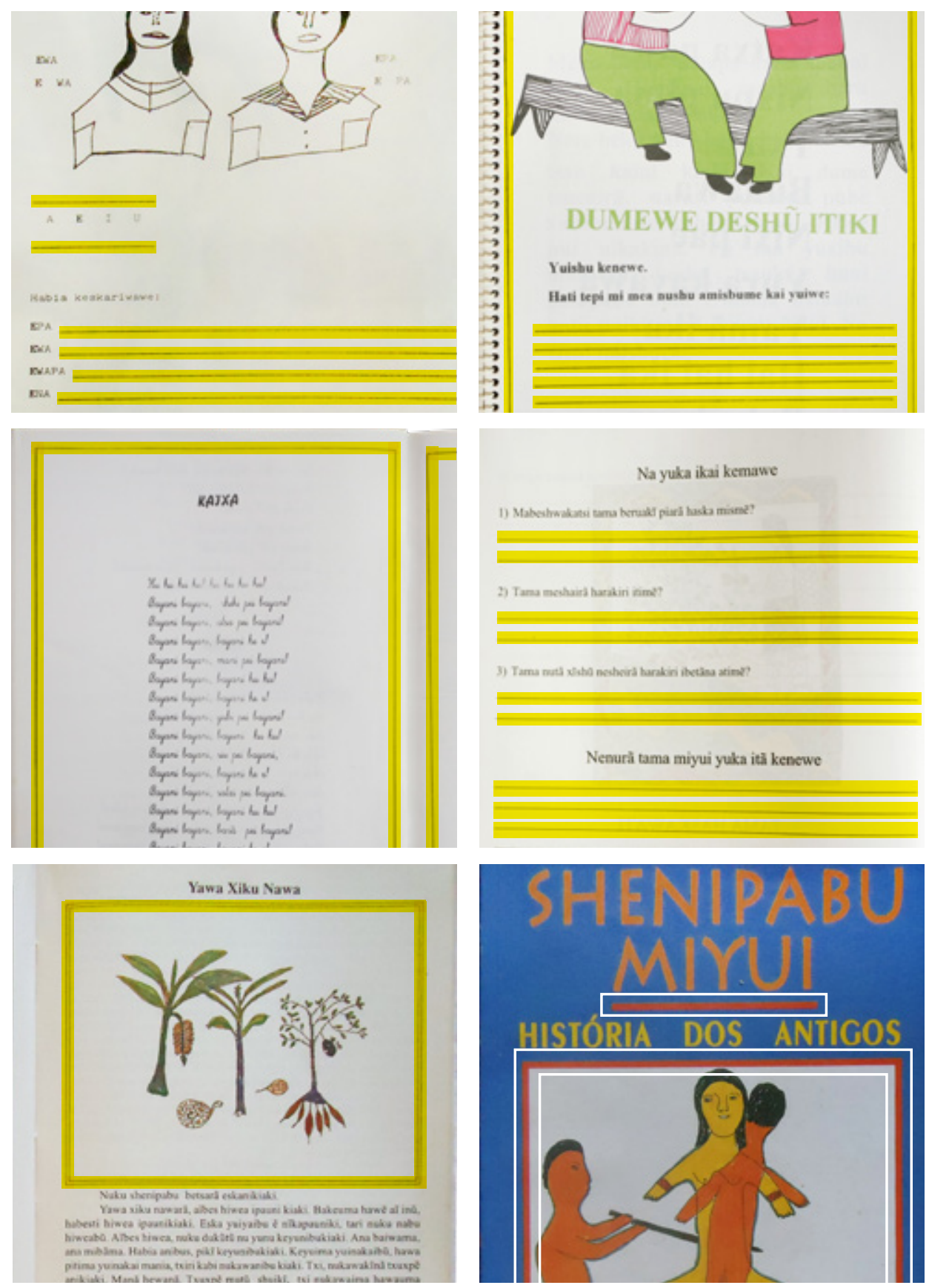

Na coletânea de mitos Shenipabu Miyui - História dos Antigos, molduras compostas por fios (duplos no miolo, simples na capa) delimitam a área de composição dos elementos pictóricos, no caso das ilustrações, não sendo utilizadas nas fotografias.

Das coletâneas de cantos, apenas a primeira edição de Nukũ Mimawa (1995) faz uso de elementos esquemáticos: uma moldura composta por um fio fino delimita a área de texto, separando-a da numeração das páginas. Segundo a entrevista realizada com o gráfico Jânio Ferreira, este era um recurso estilístico utilizado por motivos estéticos para compor as páginas (FERREIRA, 2019).

No livro de manejo florestal Uĩ Bena, áreas retangulares de cor (boxes) são utilizadas para destacar os relatos dos professores, diferenciando-os dos demais conteúdos do livro - apesar do texto escrito totalmente em hãxta kuĩ, isto é perceptível pelo uso de aspas.

Os livros e categorias não mencionados não fazem uso de elementos esquemáticos, conforme se vê na tabela 5 . 


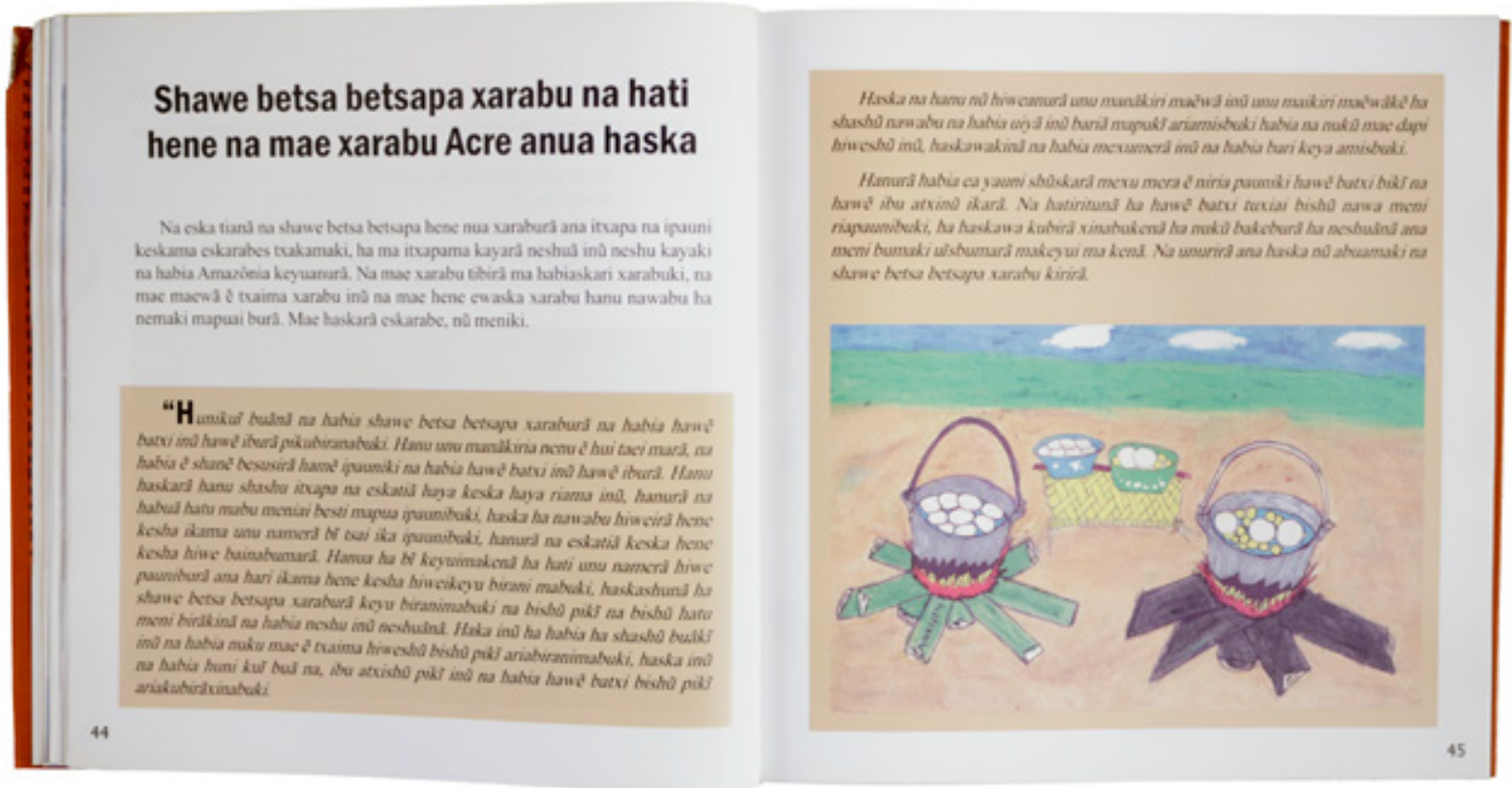

\section{Elementos verbais}

Para a análise dos elementos verbais, interessa tratar de alguns dos aspectos tipográficos e características de composição dos textos dos livros analisados. $O$ tratamento tipográfico não é uma característica gráfica de destaque nos livros da Coleção Autoria Indígena, de modo geral, e não são encontradas amostras de composições tipográficas complexas. A simplicidade é uma característica marcante, especialmente nos livros produzidos nas décadas 1980 e 1990, provavelmente associada aos meios técnicos de composição e reprodução disponíveis.

Desse modo, a primeira cartilha, de alfabetização, Cartilha Kaxinawá: Hãxta Huni Kũ (1985), teve seu texto datilografado, e utiliza a tipografia característica de máquinas de escrever. Conforme mencionado, apesar de não apresentar nenhum arranjo tipográfico de composição especialmente diferenciada, o destaque existe aqui não pela presença, mas pela ausência do elemento verbal na capa da cartilha. A capa não apresenta nenhum componente verbal, o que é inesperado ao se pensar no modelo de construção editorial do padrão ocidental, onde a capa via de regra apresenta o título da publicação, assim como o autor. Esta é uma característica compartilhada por outros livros da Coleção Autoria Indígena lançadas no mesmo período ${ }^{27}$ : a Cartilha do Índio Seringueiro (1983), Fábrica do índio (1985), Escolas da Floresta (1986) e a Cartilha Shamenawa (1989). A segunda edição da cartilha Kene, de $2001^{28}$, também compartilha esta característica, provavelmente por tratar-se da reprodução da capa da primeira edição, produzida em 1994 (conforme mencionado anteriormente, não foram encontrados exemplares desta edição em acervo).

A mesma capa, composta por uma combinação de kene coloridos ${ }^{29}$, foi utilizada para a Cartilha do Índio Seringueiro e para a Cartilha Kaxinawá: Hãxta Huni Kuĩ. Especula-se que o motivo por trás dessa decisão esteja relacionado à questões financeiras de economia, mas não se pode afirmar com certeza. Nukũ Mimawa, coletânea de cantos publicada em 1995, também não apresenta nenhum elemento verbal em sua primeira capa ${ }^{30}$.
Figura 183: Páginas do miolo de Uĩ Bena (2006) com o uso de elementos esquemáticos para organizar o conteúdo textual. Fonte: Pesquisa de campo, Paiva (2019). 
Figuras 184, 185, 186

e 187: Primiera e quarta capas de Yumebũ

Miyui - Mae Bi Kena

(1997), com detalhes dos elementos verbais.

Fonte: Pesquisa de campo, Paiva (2019).
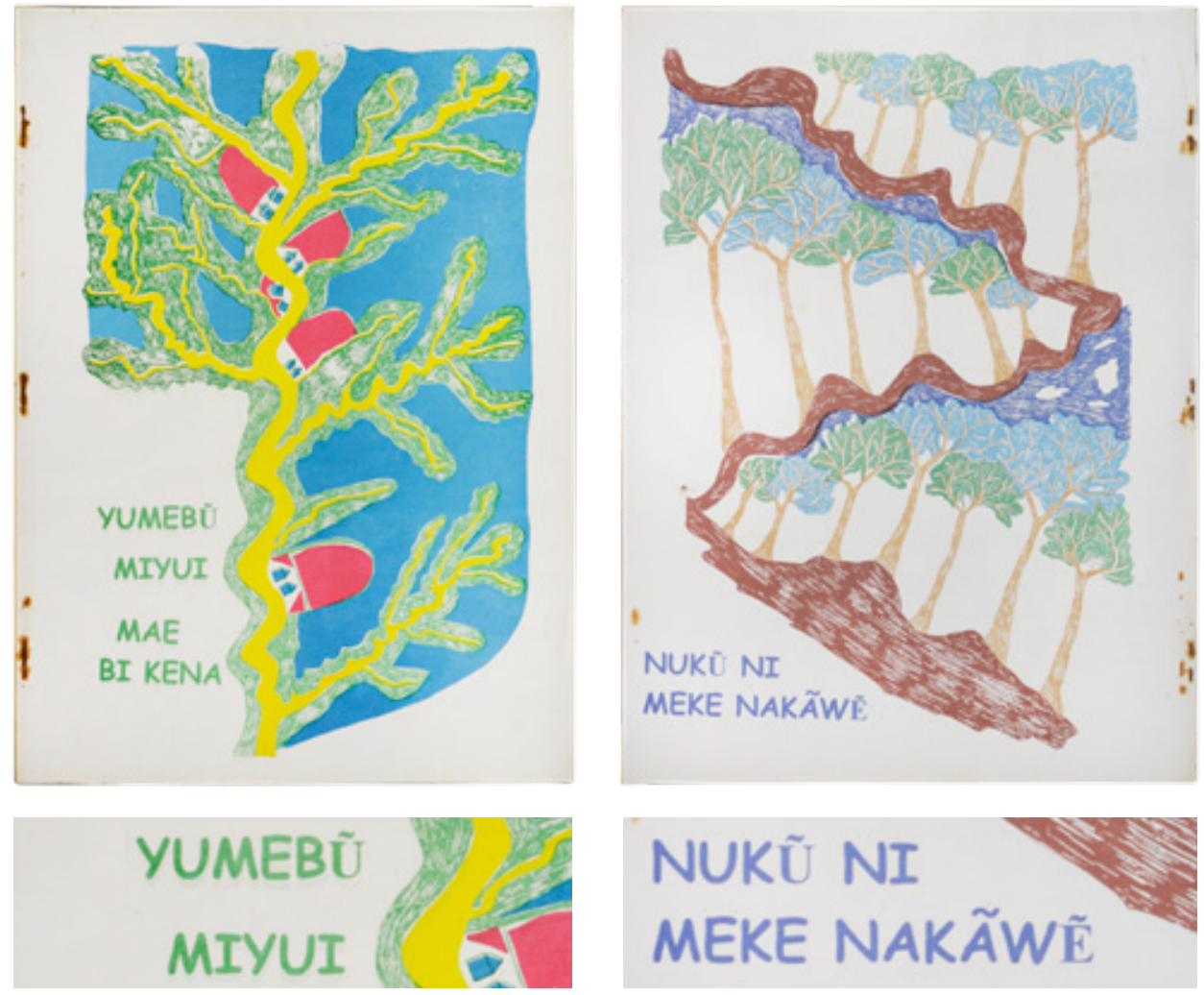

A maioria dos materiais produzidos a partir de 1994 utiliza uma mesma tipografia, produzida especialmente para adequar-se aos usos de sinais diacríticos específicos do hãxta kuĩ. Segundo informações de Sena (2019) e Noronha (2019), a tipografia foi feita a partir de uma adaptação da fonte Times New Roman ${ }^{31}$, realizada por técnicos de informática em conjunto com os professores kaxinawá. Essa fonte foi instalada nos computadores da CPI-AC para ser utilizada na composição dos layouts desenvolvidos pela equipe, e, posteriormente, era envidada aos designers que prestaram serviços para a instituição. Ainda assim, algumas capas e títulos de capítulos foram compostos com outras fontes. Nesse caso, os diacríticos, quando necessários, eram acrescentados manualmente pelos designers - procedimento que seria demasiadamente trabalhoso para os textos do miolo (NORONHA, 2020; FALCÃO, 2020).

Contudo, na capa de Yumebũ Miyui - Mae Bi Kena observa-se um problema técnico diretamente relacionado a essa questão. A fonte utilizada para compor os elementos verbais da primeira e quarta capa não possuía os caracteres combinados aos diacríticos necessários, e os mesmos foram substituídos pela fonte adaptada. Esta é uma problemática comum a outras edições de materiais em língua indígena, e foi abordada em detalhes na pesquisa desenvolvida por Diniz (2007).

Além da versão da Times desenvolvida pela CPI-AC, as tipografias utilizadas nas capas, via de regra, variam entre fontes sem serifa e tipos manuscritos (BRINGHUST, 2005). As fontes sem serifa parecem ter sido selecionadas para materiais de caráter mais "técnico-científico" como o livro de manejo de quelônios Ũ̃ Bena e o levantamento de plantas medicinais Plantas e Curas do Povo Huni Kuĩ. A exceção aqui seria a capa e contra-capa da segunda edição de Nukũ Mimawa, coletânea de $\operatorname{cantos}^{32}$ e o livro sobre

31 Segundo Bringhurst (2005, p. 109), a Times é "um pastiche histórico desenhado por Victor Lardent para Stanley Morison em Londres em 1931. Tem um eixo humanista mas proporções maneiristas, peso barroco e um acabamento preciso, neoclássico".

32 Como visto nas figuras 105 e 106, na página 118. 

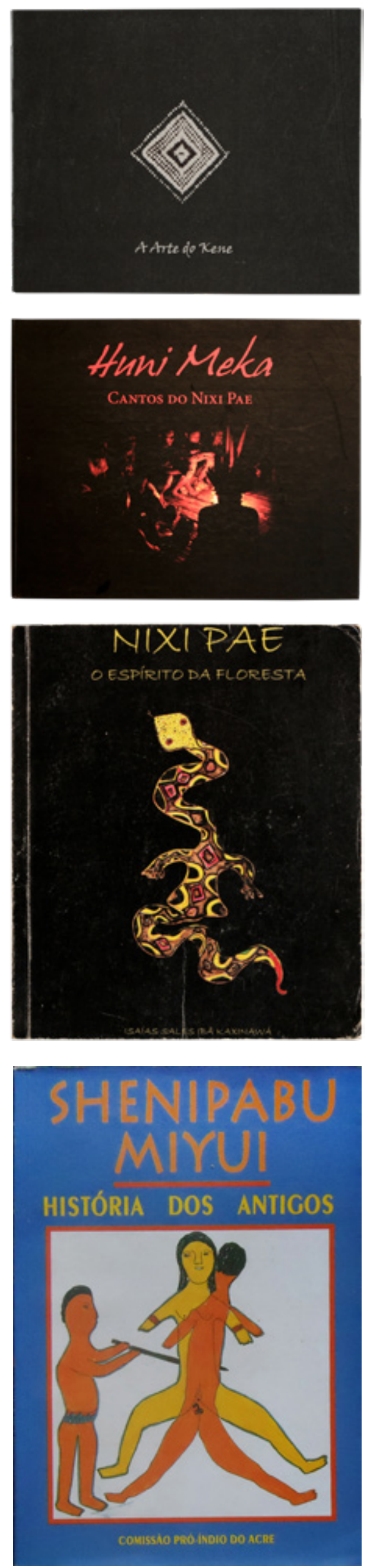
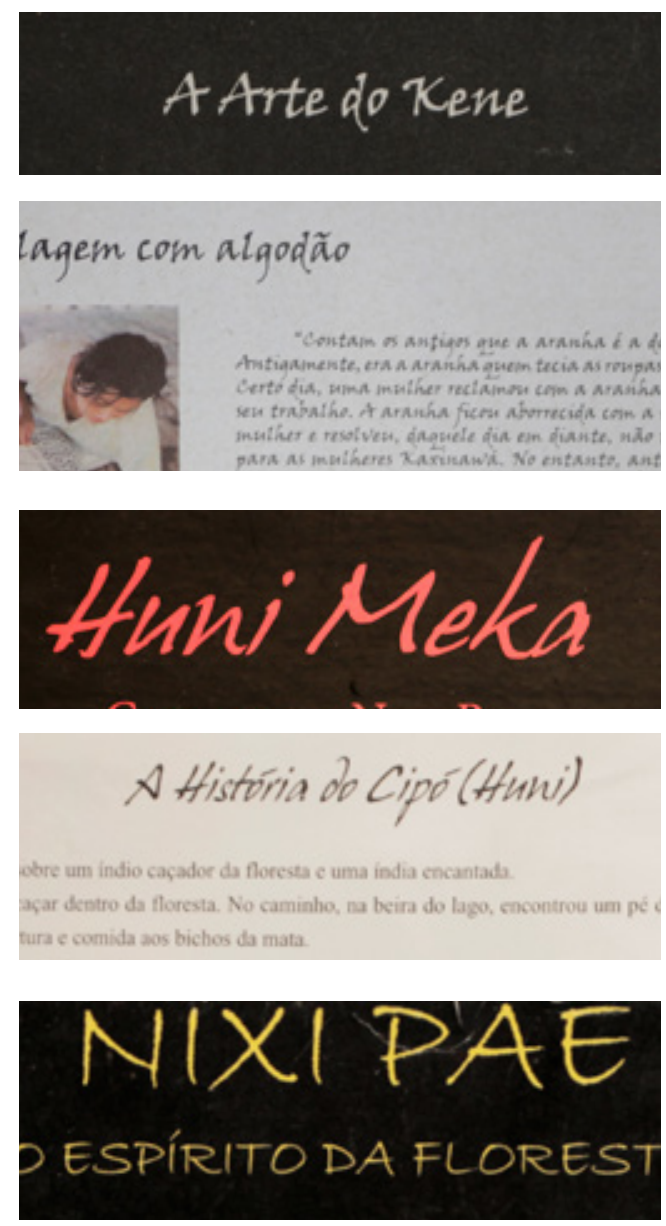

Ele parou de caminhar, tinha muit uma tocaia para poder esperar a antz palha de jarina bem fechada. Entrou 1 Nada de chegar o veado (txashu) e sono e dormiu dentro da sua tocaia. $\mathrm{L}$ se para ver o que era. Viu uma anta ( frutas de jenipapo e foi descendo de

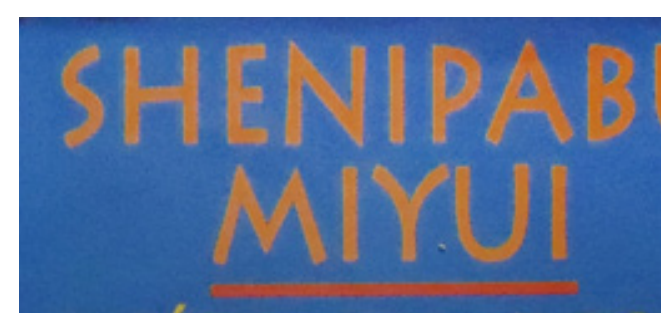
(1996). Fonte: Pesquisa
Figuras 197, 198 e 199: Primeira capa e detalhes dos elementos verbais da capa e do miolo de Shenipabu Miyui História dos Antigos de campo, Paiva (2019)

Figuras 188, 189 e 190: Primeira capa e detalhes dos elementos verbais da capa e do miolo de A Arte do Kene (2006). Fonte: Pesquisa de campo, Paiva (2019).

Figuras 191, 192 e 193: Primeira capa e detalhes dos elementos verbais da capa e do miolo de Huni Meka (2007). Fonte: Pesquisa de campo, Paiva (2019).

Figuras 194, 195 e 196: Primeira capa e detalhes dos elementos verbais da capa e do miolo de Nixi Pae - O Espírito da Floresta (2006). Fonte: Pesquisa de campo, Paiva (2019).
Nuku shenipabu betsarã eskani Yawa xiku nawarã, aĩbes hiwea besti hiwea ipaunikiaki. Eșka yuiya veabũ. Aĩbes hiwea, nuku dukũtũ nu ? a mibãma. Habia anibus, pikĩ keyunit ima yuinakai mania, txiri kabi nukaw: ikiaki. Manã hewanã. Txuxpẽ mutũ 

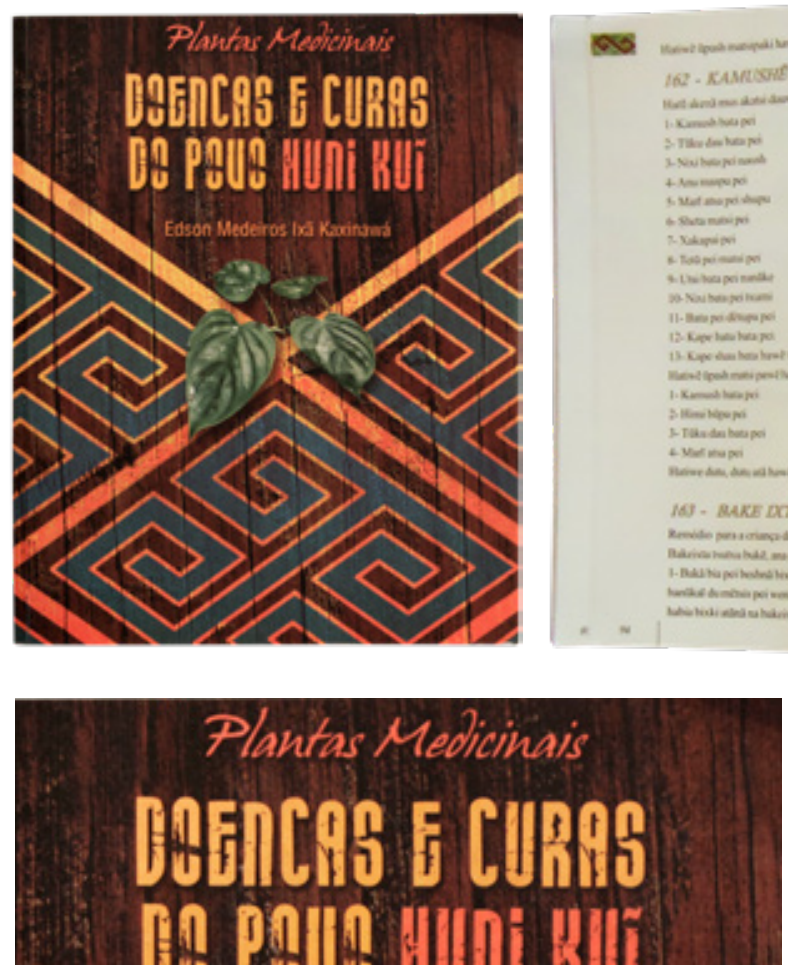

Plantas Medicinais

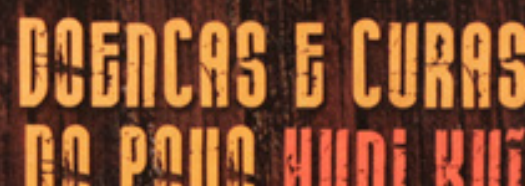

Escolhi o tema porque no meu povo são poucos mantêm o conhecimento sobre as plantas medicinais. T: durante os cursos de formação para professores indige "Uma Experiência de Autoria", os assessores trabalha aulas de ciências, junto com o setor de saúde.

Figuras 200, 201, 202 tecelagem Miyui Mimã Kene - A arte de Tecer ${ }^{33}$. Já os tipos manuscritos são e 203: Primeira capa, mais utilizados nos livros de cantos: nas capas de A Arte do Kene, de Nixi páginas do miolo e detalhes dos elementos verbais da capa e do miolo de Doenças e Pae - O Espírito da Floresta, e no miolo da primeira edição de Nukũ Mimawa. A exceção é A Arte do Kene, livro sobre tecelagem e cultura material.

Shenipabu Miyui - História dos Antigos, é o único livro cuja capa é composta com uma versal de inscrição. A Lithos é uma "versal sem serifa com abertura grande e forma vivaz, baseadas em antigas letras de inscrição gregas" (BRINGHUST, 2005, p. 309).

\section{Elementos pictóricos}

Os elementos pictóricos dividem-se entre ilustrações e fotografias. Até os anos 2000 as fotografias eram raramente utilizadas na composição dos projetos dos livros - mais uma vez devido às restrições técnicas dos equipamentos disponíveis na gráfica interna ${ }^{34}$, e novamente a exceção é o livro Shenipabu Miyui - História dos Antigos que, apesar de impresso no período de funcionamento da gráfica interna, não foi impresso na mesma.

Mesmo com o aumento no uso de fotografias que ocorreu a partir do início dos anos 2000, as ilustrações ainda representam a maior parte dos elementos pictóricos presentes nos livros. Além disso, a análise das capas dos livros de leitura (PAIVA, SOUSA, 2019), e o levantamento bibliográfico apresentado no início deste capítulo permitem perceber que as ilustrações possuem um papel significativo como dimensão visual do conceito de autoria indígena e de representação da cultura Kaxinawá. Por tais motivos, optou-se por restringir a análise dos elementos pictóricos às ilustrações.

Para tanto, utilizou-se o método proposto por Goldsmith (1980), que parte da combinação entre as três categorias de interpretação semiótica propostas por Morris (1938, apud GOLDSMITH, 1980) e os quatro "fatores visuais" selecionados pela autora (GOLDSMITH, 1980, p. 205). Dessa forma, somam-se doze possíveis níveis de interpretação de uma imagem, 
NÍVEIS SEMIÓTICOS

\begin{tabular}{|c|c|c|c|}
\hline $\begin{array}{l}\text { FATORES } \\
\text { VISUAIS }\end{array}$ & SINTÁTICO & SEMÂNTICO & PRAGMÁTICO \\
\hline UNIDADE & $\begin{array}{l}\text { DEFINIÇÃO DA IMAGEM } \\
\text { TOLERÂNCIA PERCEPTIVA }\end{array}$ & $\begin{array}{l}\text { RECONHECIMENTO } \\
\text { CARACTERÍSTICAS } \\
\text { DISTINTIVAS }\end{array}$ & $\begin{array}{l}\text { FAMILIARIDADE } \\
\text { COMPREENSÃO DE } \\
\text { CONTEXTOS }\end{array}$ \\
\hline LOCAÇÃO & $\begin{array}{l}\text { PERSPECTIVAS } \\
\text { PROFUNDIDADE } \\
\text { PLANOS VISUAIS }\end{array}$ & $\begin{array}{l}\text { PLANIFICAÇÃO } \\
\text { ESCALAS } \\
\text { PERCEPÇÃO DA } \\
\text { PROFUNDIDADE }\end{array}$ & $\begin{array}{l}\text { EXPERIÊNCIA DO } \\
\text { OBSERVADOR } \\
\text { ACEITABILIDADE DA } \\
\text { SITUAÇÃO REPRESENTADA } \\
\text { ILUSÕES DE ÓTICA }\end{array}$ \\
\hline ÊNFASE & $\begin{array}{l}\text { CONTRASTES } \\
\text { USO DE ELEMENTOS } \\
\text { "DISSONANTES" }\end{array}$ & $\begin{array}{l}\text { DISPOSITIVOS DE } \\
\text { COMPOSIÇÃO } \\
\text { DIRECIONAMENTO DO } \\
\text { OLHAR }\end{array}$ & $\begin{array}{l}\text { FENÔMENOS PERCEPTIVOS } \\
\text { COMUNS (TENDÊNCIAS DE } \\
\text { LEITURA POR EX.) }\end{array}$ \\
\hline $\begin{array}{l}\text { PARALELOS } \\
\text { TEXTUAIS }\end{array}$ & $\begin{array}{l}\text { RELAÇÃO ESPACIAL } \\
\text { ENTRE SINAIS VERBAIS } \\
\text { E PICTÓRICOS }\end{array}$ & $\begin{array}{l}\text { DISTINÇÃO DOS ASPECTOS } \\
\text { DA IMAGEM } \\
\text { PROBLEMAS DE } \\
\text { IDENTIFICAÇÃO }\end{array}$ & $\begin{array}{l}\text { REFERÊNCIAS SIMBÓLICAS } \\
\text { COMPARTILHADAS POR } \\
\text { TEXTO E IMAGEM } \\
\text { REPRESENTAÇÃO DE } \\
\text { CONCEITOS ABSTRATOS }\end{array}$ \\
\hline
\end{tabular}

conforme apresentado na tabela 6. Levando-se em consideração que os níveis semióticos funcionam de maneira a aprofundar o papel do observador e sua interpretação, sendo o nível pragmático o que considera esta interpretação de maneira mais significante, e como este trabalho está voltado para a compreensão da emissão dos projetos dos livros analisados, ao invés de sua recepção - estudo que demandaria ferramentas mais complexas e outras bases conceituais e teóricas, assim como o contato direto com usuários dos títulos - a análise realizada considera apenas os níveis sintático e semântico.

Centenas de ilustrações compõem as capas e miolos dos 17 livros aqui analisados. A análise de todas elas, além de inviável no tempo hábil disponível para a realização desta pesquisa, acredita-se que os resultados seriam exagerados e maçantes. Portanto, no intuito de facilitar a sistematização e a realização da análise, optou-se por desenvolvê-la a partir de cada fator visual, analisado, respectivamente, nos níveis sintáticos e semânticos. Buscou-se destacar, em cada um deles, as características que mais se destacam no conjunto geral de ilustrações.

\section{Unidade}

A unidade sintática diz respeito à percepção de uma imagem enquanto uma unidade distinta e específica, assim como das unidades gráficas que a compõem - linhas, pontos, retículas (GOLDSMITH, 1980). As ilustrações analisadas, de modo geral, não apresentam problemas de definição ou percepção. Há uma preocupação com sua reprodução, de modo que possam permanecer o mais próximo possível dos originais produzidos pelos professores indígenas, e que sejam, também, reproduzidas com qualidade. Sena (2019) menciona várias vezes em entrevista uma preocupação com "a be-
Tabela 6: Apresentação sistemática do método de análise de imagens proposto por Goldsmith (1980). Fonte: Adaptação da autora a partir de Goldsmith (1980). 

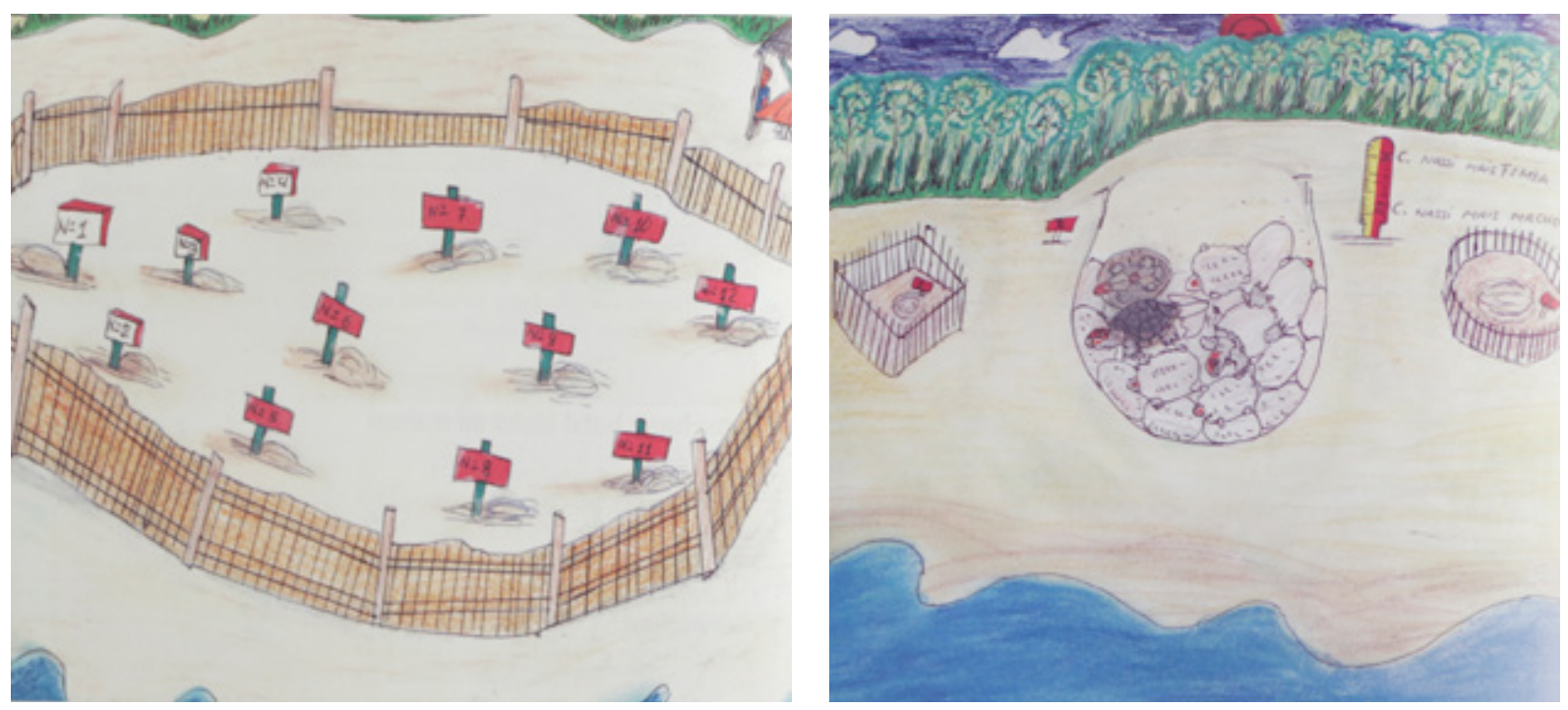

Figuras 204 e 205: leza estética" dos livros produzidos pela CPI-AC e os designers, Noronha e llustrações do miolo de Uĩ Bena (2006). Fonte:

Falcão (2019) também ressaltaram a organização e cuidado com os quais os materiais são entregues para a diagramação. Originais encontrados em acervo também permitiram perceber o cuidado com o qual a "transcrição gráfica" das ilustrações era realizada, mesmo antes de haverem scanners e câmeras digitais. Os desenhos possuem um caráter intrinsicamente bem delimitado, com o uso de linhas para contornos e áreas bem estabelecidas de cor e forma. Não há experimentações com desfoque, por exemplo, ou mesmo o uso de hachuras.

Se a unidade sintática diz respeito apenas ao potencial de reconhecimento de uma imagem enquanto uma figura específica, a unidade semântica aprofunda o nível de reconhecimento, preocupando-se com a capacidade representativa e comunicativa dos elementos representados (GOLDSMITH, 1980). Neste momento é interessante pensar nos objetivos dos livros. A maior parte dos livros de autoria kaxinwá ilustrados pertencem a categorias temáticas onde as ilustrações devem, necessariamente, representar elementos muito específicos. No livro de manejo, as ilustrações demonstram procedimentos específicos, tendo, inclusive, um caráter técnico como um "manual" a ser seguido. De modo semelhante, em Doenças e Curas as ilustrações representam plantas específicas, no molde de ilustrações botânicas, devem permitir que o leitor identifique os espécimes em questão.

Nas cartilhas de alfabetização e geografia, as ilustrações estão diretamente relacionadas aos conceitos que estão sendo trabalhados em texto. Segundo as entrevistas com Sena (2019) e Gavazzi (2019), um dos principais critérios para a seleção das ilustrações era precisamente a representação clara do tema a ser ilustrado. Ainda assim, há um caráter estilizado e sintético que se destaca, especialmente em algumas ilustrações das cartilhas.

Shenipabu Myiui é o único livro que "permite", de certo modo, uma abordagem que é às vezes mais abstrata das cenas representadas. Em alguns momentos, de fato, é difícil para o observador compreender exatamente o que se passa na imagem, sem o auxílio da informação verbal.

\section{Locação}

A locação é o fator visual que se refere, basicamente, à percepção da profundidade de uma imagem. Nesse sentido, a inserção dos sujeitos representados (objetos, pessoas, animais etc) em cenários, assim como o modo pelo qual esses cenários são construídos e reproduzidos, são o ponto focal deste momento da análise (GOLDHSMITH, 1979). A localização sintática diz res- 


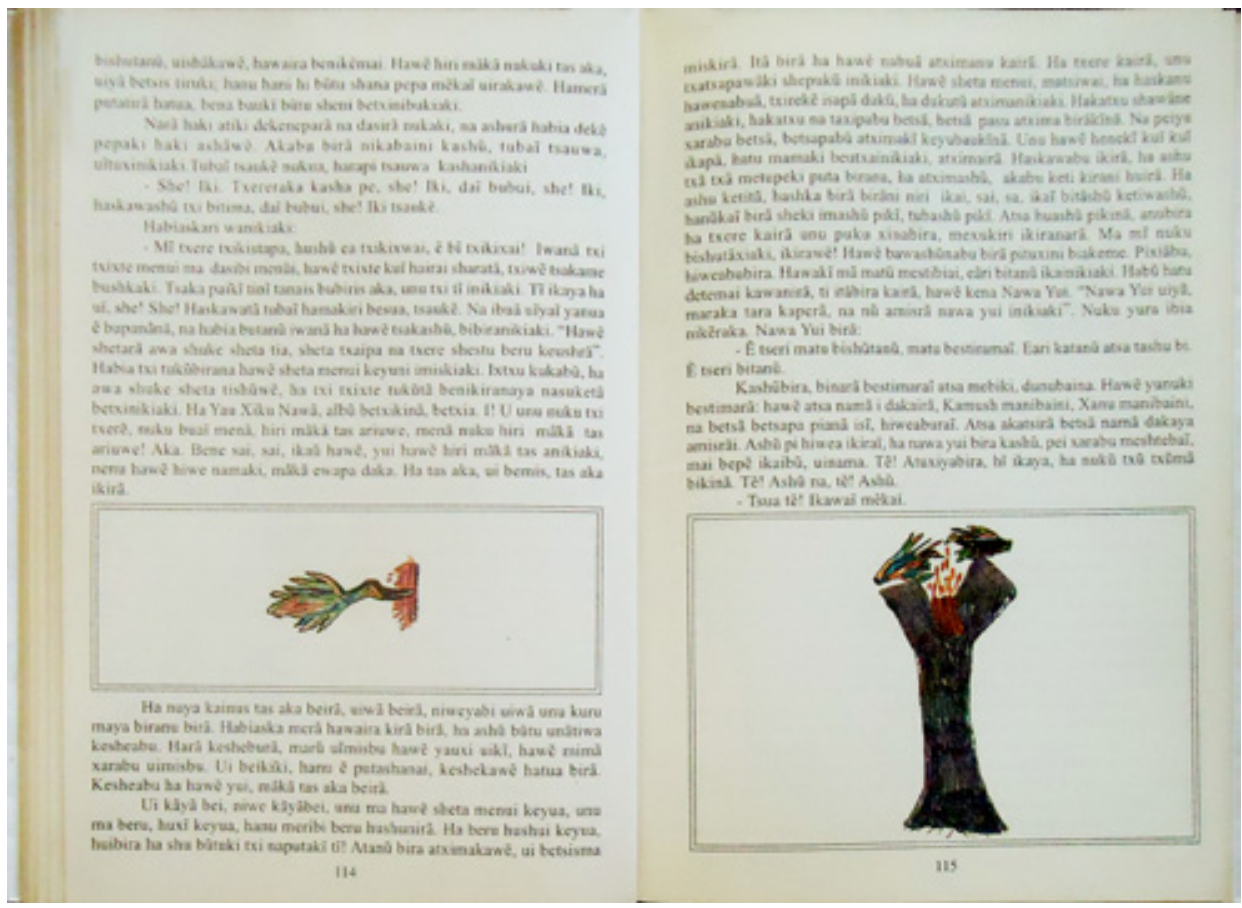

Figura 206: Páginas ilustradas do miolo de Shenipabu Miyui História dos Antigos (1996). Percebe-se que há certa dificuldade em compreender as cenas retratadas nas ilustrações. Fonte: Pesquisa de campo, Paiva (2019).
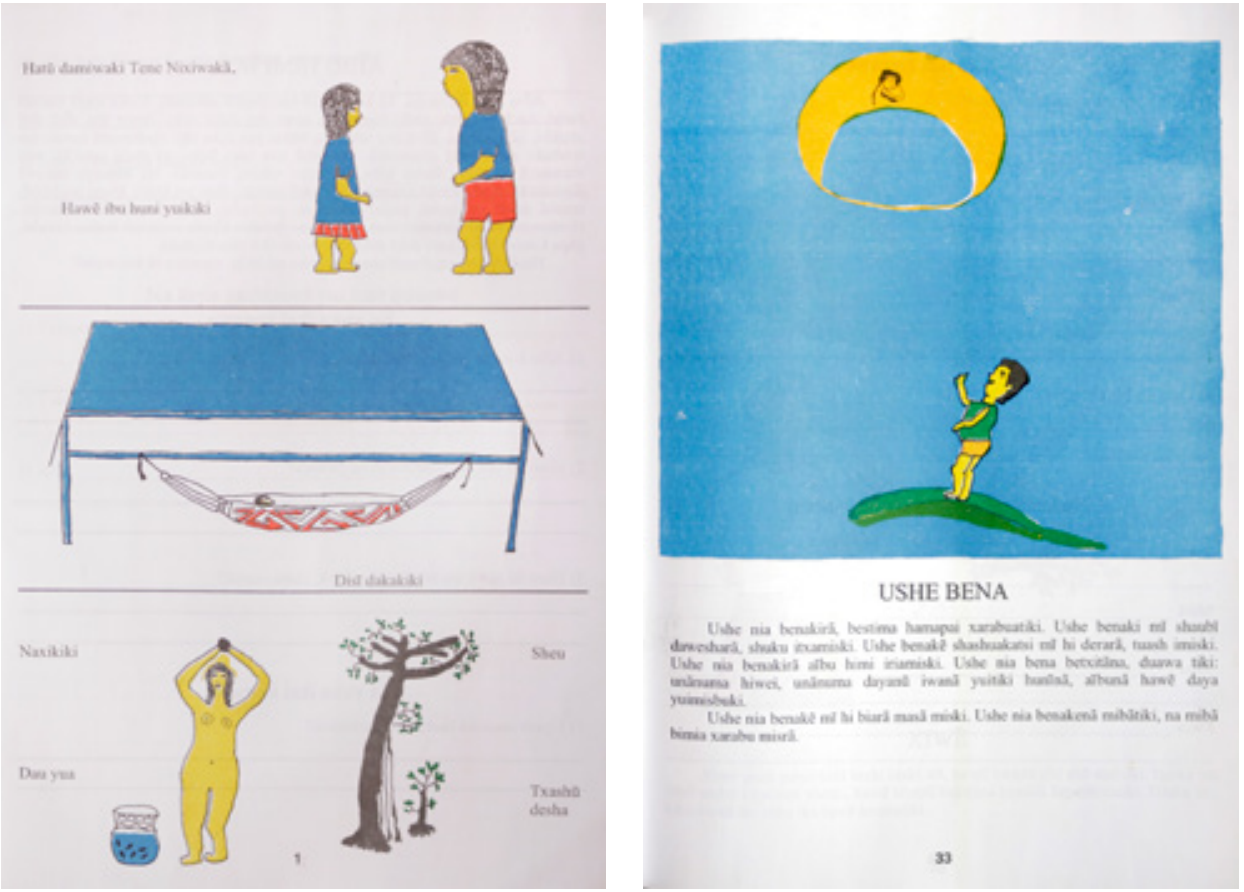

Figuras 207 e 208:

Páginas ilustradas do miolo de Kene $2^{\circ}$ ed. (2001), contrastes entre cores, escalas interpretativas, ausência e presença de cenários / fundo nas ilustrações. Fonte: Pesquisa de campo, Paiva (2019).

peito ao uso de perspectivas e planos visuais na composição das imagens, já a locação semântica trata da percepção de profundidade ou da planificação e das escalas utilizadas na composição da imagem.

Desse modo, há duas abordagens aqui. Uma se relaciona às figuras que não possuem cenários, ou que foram recortadas de suas composições originais e compostas na página. Este é o caso de boa parte das ilustrações das cartilhas, tanto as de alfabetização quanto às de geografia, das plantas ilustradas em Doenças e Curas e das pequenas (e poucas) ilustrações recortadas em Huni Meka ${ }^{35}$.

Nessas ilustrações, a locação sintática está mais relacionada ao uso de perspectivas na composição dos desenhos isolados, o que não se apresenta enquanto uma característica comum das ilustrações. Pelo contrário, 

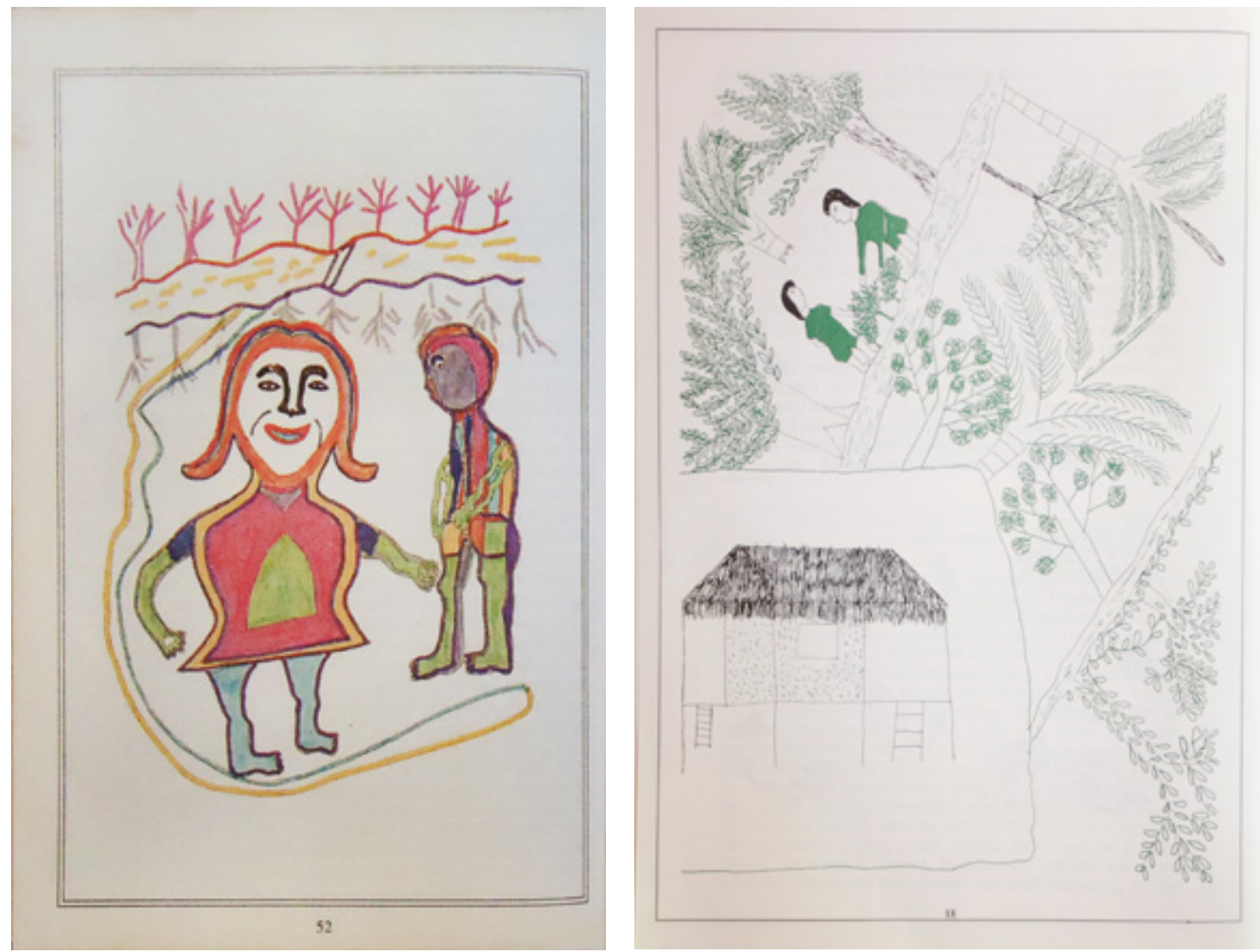

Figura 209: e agora já tratando da locação semântica, elas são marcadas pela planifica-

Página do miolo de Yumebũ Miyui - Mae Bi Kena (1997). Fonte:

Pesquisa de campo,

Paiva (2019).

Figura 210: Página do miolo de Yumebũ Miyui

- Mae Bi Kena (1997).

Fonte: Pesquisa de

campo, Paiva (2019). ção, tanto de elementos isolados quanto dos planos visuais que compõem os cenários (tratados mais adiante). As escalas aqui estariam relacionadas à composição de mais de uma ilustração na página, como é comum encontrar nas cartilhas. Nesses casos, as escalas não são utilizadas como guia para o dimensionamento dos desenhos na página. Aparentemente, a preocupação maior parece ter sido a composição das imagens na página de modo geral.

A se tratar da locação sintática das ilustrações apresentadas com cenários, a profundidade é construída através da combinação entre planos visuais, que às vezes apresentam perspectivas conflitantes (por exemplo, as figuras em primeiro plano são apresentadas a partir de um ponto de vista frontal, enquanto parte do cenário é apresentado como visto de cima). Desse modo, a perspectiva geral da composição é construída a partir das relações entre os planos, e via de regra são mais interpretativas do que geométricas. Encontram-se fundamentalmente conectadas à planificação.

A planificação também é uma característica comum das ilustrações apresentadas com cenários, a principal representação de sua locação semântica. Os planos visuais, planificados, são apresentados com praticamente nenhum uso de gradientes (para demonstrar profundidade e as relações entre luz e sombra, por exemplo). As escalas são intuitivas, e mais interpretativas do que realistas, causando um certo "estranhamento" ao observador habituado às representações comuns no mundo ocidental.

Interessa também tratar da sobreposição de planos, ocasionada tanto nas composições das imagens, quanto pela impressão sobreposta de blocos de cores, que, conforme descrito no capítulo 3 , decorria da dificuldade de regulagem do registro na impressora disponível na gráfica interna. Apesar de não ser um aspecto proposital, a presença das sobreposições de cores se dá de forma tão constante, que a característica passa a fazer parte intrínseca das ilustrações da Coleção de modo geral, assim como do recorte explorado nesta análise. 


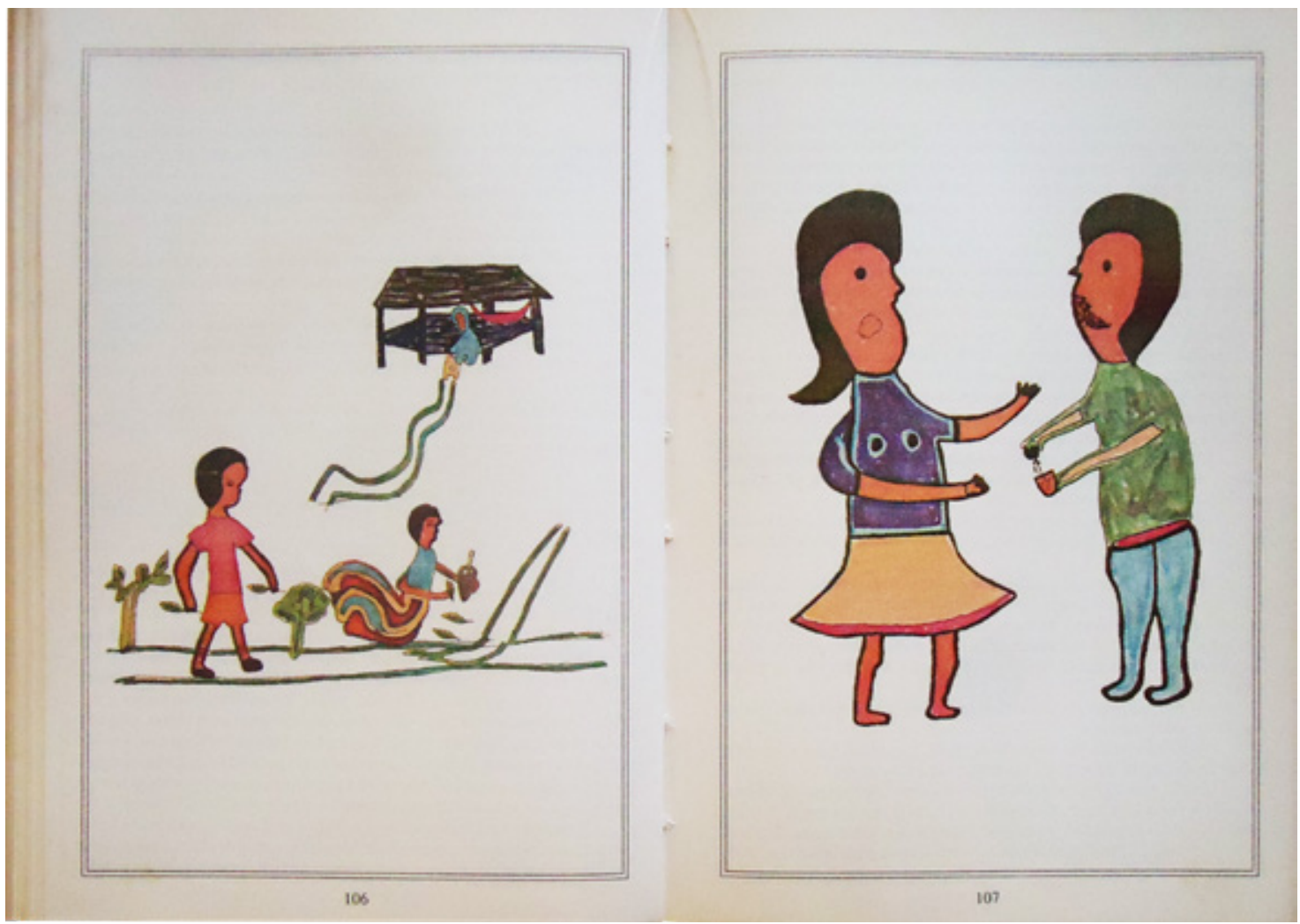

\section{Ênfase}

Se a locação se preocupa com as relações entre o posicionamento dos elementos que compõem uma imagem, a ênfase é o fator visual que abrange as relações hierárquicas entre tais elementos, assim como o detalhamento dos mesmos em vistas de potencializar suas capacidades comunicacionais (GOLDSMITH, 1980).

Desse modo, a começar pela ênfase sintática, tem-se uma das características mais marcantes das ilustrações analisadas: o contraste. $\mathrm{O}$ uso de contrastes é muito comum enquanto elemento compositivo, e se manifesta em várias instâncias. A manifestação mais comum é o contraste cromático, obtido através da utilização de cores vibrantes em tons variados e que se faz presente em todas as ilustrações impressas em policromia.

Contrastes interessantes também são obtidos através da variação de escalas (um desdobramento das escalas interpretativas mencionadas na locação semântica). A combinação entre cores e escalas funcionam como atrativos ao olhar, pois produzem contrastes inesperados (GOLDSMITH, 1980).

A ênfase semântica é marcada pelo uso de contraposições perceptivas: em uma mesma imagem se encontram, ao mesmo tempo, representações muito detalhadas e muito sintéticas e estilizadas. A aplicação de texturas também funciona como um modo de direcionar o olhar e diferenciar áreas da composição, detalhando os animais, objetos ou pessoas representadas - a ênfase, em termos de hierarquia, costuma residir nos sujeitos centrais das composições, que geralmente se alternam entre estes temas, fora as representações híbridas de humanos com características animais e vice-versa, via de regra presentes nas ilustrações de narrativas que envolvem estes seres.

Outra característica relacionada ao nível semântico da ênfase é a utilização de canetas hidrocor e lápis de colorir como principais materiais para a produção das ilustrações (SENA, 2019). Essas ferramentas, combinadas à forma de reprodução, com linhas e áreas bem definidas de cor, realça os traços das ilustrações, trazendo a ênfase para a característica manual acentuada das composições, que dita o tom das ilustrações dos livros, de maneira geral.
Figura 211: Páginas ilustradas do miolo de Shenipabu Miyui História dos Antigos (1996). Fonte: Pesquisa de campo, Paiva (2019). 

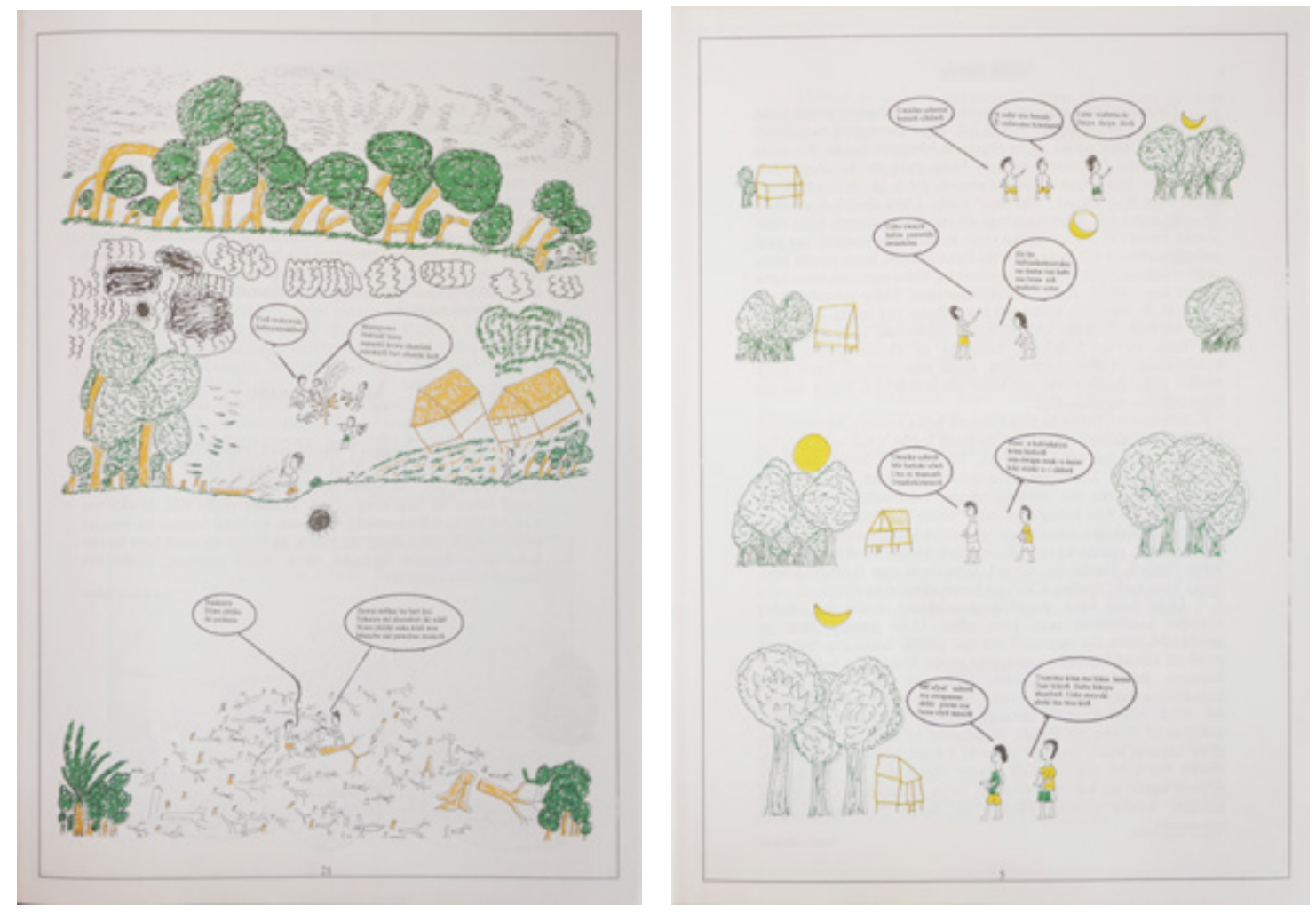

Figuras 212 e 213: Paralelos textuais

Páginas do miolo de Yumebũ Miyui - Mae Bi Kena (1997). Fonte:

Os paralelos textuais tratam, como o nome sugere, das relações entre texto e imagem, seja no que diz respeito ao posicionamento dos elementos verbais e pictóricos na página e qual dos dois recebe mais destaque - dimensão sintática - seja no que se refere a questões de definição entre texto e imagem - dimensão semântica (GOLDSMITH, 1980).

As áreas designadas para os elementos verbais e pictóricos são, via de regra, bem definidas nos livros analisados. São poucos casos nos quais há interações inusitadas entre os dois elementos, tendo em vista que os elementos verbais são geralmente diagramados em blocos retangulares de texto. Em termos de hierarquia, elementos verbais e pictóricos costumam receber ênfases semelhantes nas páginas dos livros - que Souza chama de texto multimodal (2006), onde a informação verbal é composta em conjunto com as informações visuais, caracterizando uma relação de co-dependência.

Uma relação interessante, apesar de pouco comum, é encontrada em Yumebũ Miyui Mae Bi Kena, com pequenas histórias em quadrinhos e o uso de balões para os diálogos.

No que diz respeito ao nível semântico, algumas questões podem ser levantadas ao se tratar dos problemas de identificação. Há níveis para a identificação dos elementos retratados, já que boa parte dos mesmos é voltado para uma cultura específica, o que inclui um outro olhar. De todo modo, por mais que não seja possível para o leitor não-indígena, muitas vezes, identificar aspectos muito específicos das imagens, os mesmos são reconhecíveis num nível mais macro. Por exemplo, talvez não se saiba que pássaro específico está sendo representado, mas se compreende que se trata de um pássaro.

\section{O uso de kene}

Os kene aparecem nas composições de duas formas principais: como parte de uma composição maior, ou seja, aplicados sobre artefatos, pessoas e animais desenhados; ou por conta própria, em composições que assumem variados formatos. 


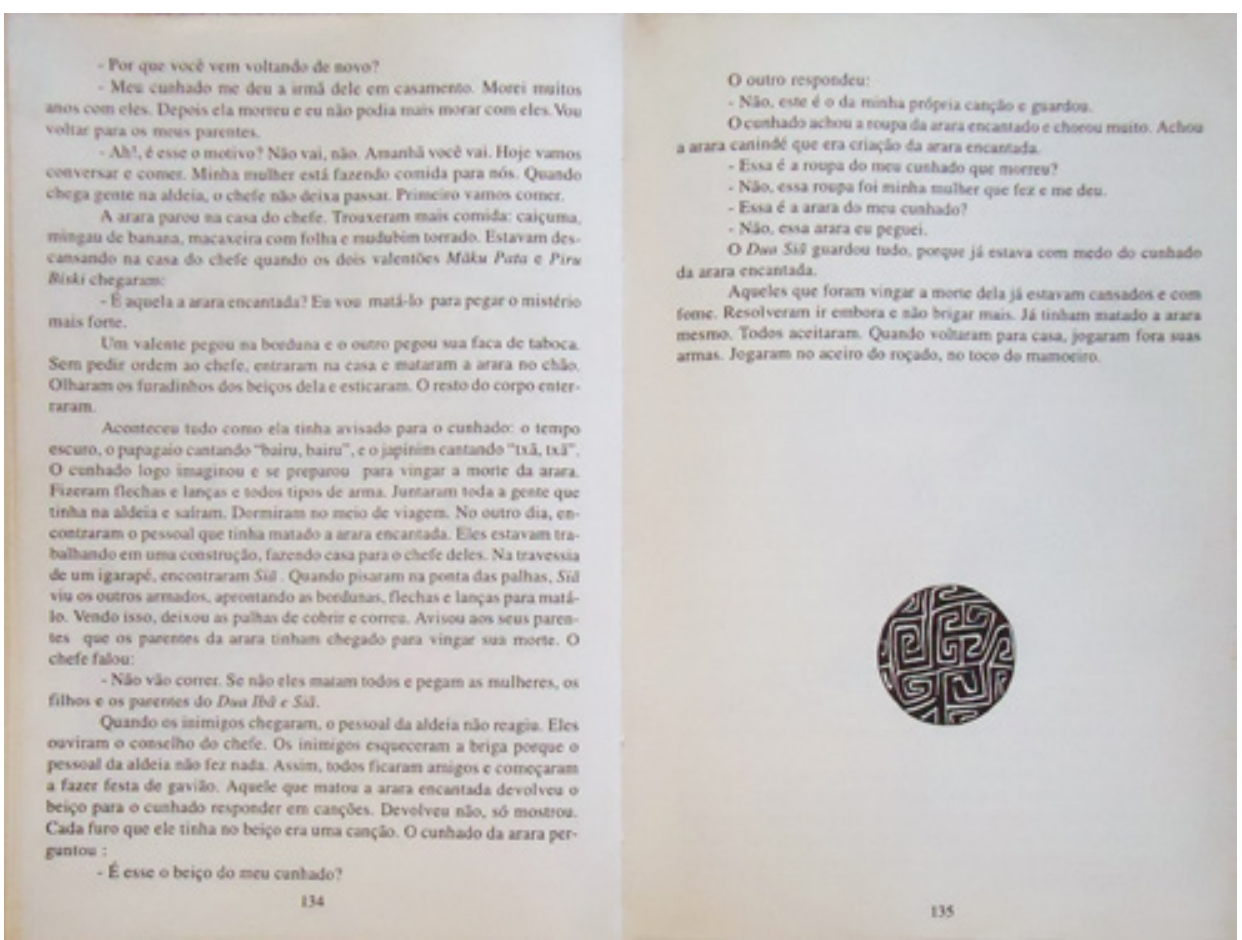

Shenipabu Miyui é um dos primeiros livros da Coleção em que pequenas composições de kene são utilizadas para pontuar as páginas de texto. Segundo Janio Ferreira, gráfico da CPI-AC naquele período, esta foi uma ideia de Renato Gavazzi para aumentar o aproveitamento das páginas, assim como utilizar os kene como elementos ilustrativos dos conteúdos (FERREIRA, 2019).

Posteriormente esta se tornou uma prática comum, que foi aplicada em outros títulos da coleção, conforme se observa, por exemplo, em Ũ Bena e Miyui Mimã Kene - História da Arte de Tecer. Em Nixi Pae uma faixa de kene demarca a sessão do livro onde é narrada a história de origem do cipó ${ }^{36}$.

Entretanto, tanto Janio quanto os designers entrevistados (NORONHA, 2019; FALCÃO, 2019) relatam que não havia uma lógica específica no que diz respeito aos significados dos kene utilizados e sua relação semântica com o conteúdo das páginas.

Em Nukũ Mimawa, o primeiro livro de música kaxinawá publicado pela CPI-AC, a única ilustração utilizada no miolo é uma das aplicações mais interessantes do kene enquanto composição pictórica. Trata-se de uma grande combinação de kene em conjunto com uma cabeça humana. Composição semelhante é encontrada em Doenças e Curas (a única ilustração do livro que não representa uma das plantas do levantamento realizado). Este também é o único caso em que o designer interveio diretamente na configuração visual de uma ilustração (excluindo-se recortes e tratamento básico de imagens), acrescentando uma textura semelhante a de um papel fibroso, simulando um suporte falso para o desenho. Na capa do mesmo livro, Maurício de Lara Falcão, o designer responsável pelo projeto, reproduziu uma composição de kene através de uma ilustração em vetor, aplicada sobre uma imagem que reproduz uma textura de madeira. Completando a composição, há uma fotografia recortada de folhas de uma planta não identificada.

Outra aplicação significativa dos kene se deu nas capas dos materiais, especialmente dos primeiros. Nestes casos, os grafismos tomam todo o espaço da página e não competem com elementos verbais, sendo a única identificação do material. Na cartilha Kene eles também tem um papel de
Figura 214: Páginas do miolo de Shenipabu Miyui - História dos Antigos (1996). Uma composição circular de kene é utilizada para demarcar o fim de cada narrativa. Fonte: Pesquisa de campo, Paiva (2019). 
Figuras 215 e 216:

Página do miolo de Uĩ Bena (2006) e detalhe.

Uma composição retangular de kene é utilizada para demarcar seções do texto. Fonte:

Pesquisa de campo, Paiva (2019).

Figuras 217 e 218: [Abaixo] Páginas do miolo de Miyui Mimã Kene - História da Arte de Tecer (2000). Fonte:

Pesquisa de campo Paiva (2019).

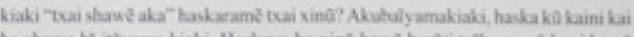
ha shawe hì itlyama kiaki. Haskaya ha xinó hawz berviti tolikamawa buai hawe kini anu hiki yamakiaki ha shawera. Haska una nai hanu nawaituanu nukuél

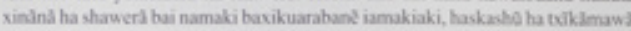

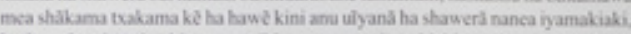
haskaya ha xies sima bita ured ti iki unu pese sa lamakiaki. Haskani imidtiaki na eskatia detxi đetxipa nô ữ misể.

Neshu miyui

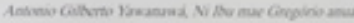

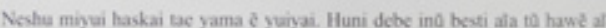
vuill piaya kanawe? Aka "mil tawa daii ikai ml piaya kivmekl aka, kuma kul

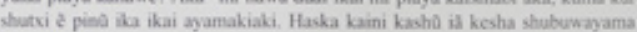

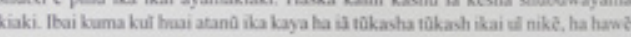
al n', yukay ama kiaki mi haskai ana benimama ikair" Hiwetl karinue aka: "Hat: Beshu ê uilsma ê ul ikai ayama kiaki". 200 neshu uf iamakiaki. laskaya ha nechy yuxi haki inkali dotrayama kiaki. Neshu yuxint ha huni debuakind. Haska bestiki

\section{$\%$}

\section{Antonio Gilberto Yau}

i tae yama ẽ yuiyai. Huni de ka "mĩ hawa duai ikai mĩ pia ayamakiaki. Haska kaini kas i atanũ ika kaya ha iã tũkasha nĩ haskai ana benimama ikai?" ayama kiaki", 200 neshu uĩ ia ama kiaki. Neshu yuxinẽ ha hu

23

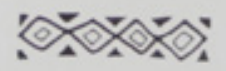

MMÃ HASKA

Nuka kene buirà eskanikiaki. Altu yube sheni bake bimashu yumewalir hawe kene yukaki na é mia yumewairà mil kene mil e a initinume kaina cuană shebô pei.

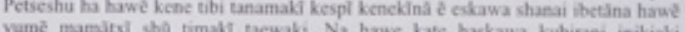
yumể mamitsi sha timaki tewaki. Na hawe kate haskawa kubirani inikiaki

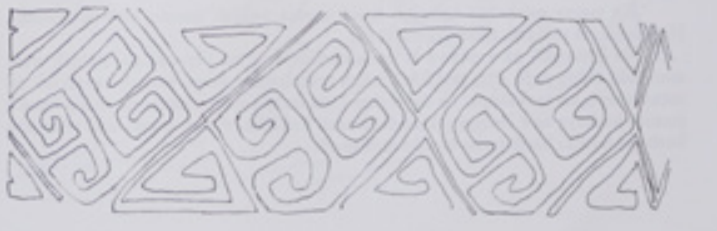

O TAMANHO DE SUA ÁRTE

Para faxer uma rede colocida os primeiros fios sio brancos. Pan fazer uma gede listrada, precisa de varias cores de fio

X race lastrabla bem tecida dura mais que a rede colonida, porque foi meite corida e muito lavada. Prexisa de dois novelos para tecer o paso. Isso vai depender

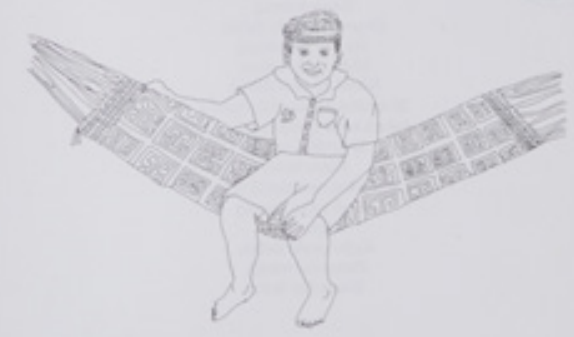

Figura 219: [À esquerda, em cores] llustração do miolo de Doenças e Curas do Povo Huni Kuĩ (2006) Fonte: Pesquisa de campo, Paiva (2019).

Figura 220: [À direita, em preto e branco] llustração do miolo de Nukũ Mimawa (199u).

Fonte: Pesquisa de campo, Paiva (2019)
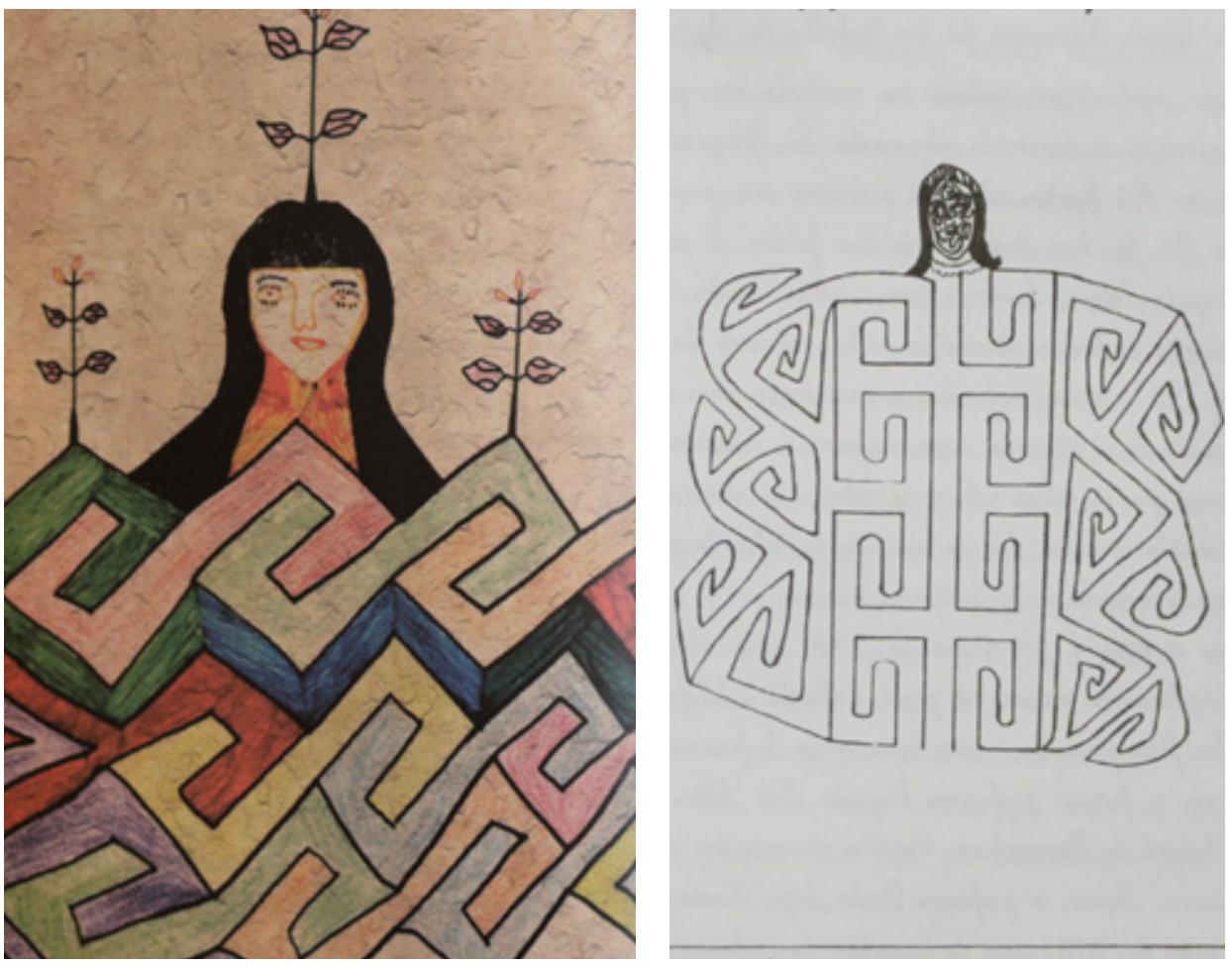
destaque na composição da primeira e da quarta capa ${ }^{37}$, embora nesse caso específico estejam acompanhados de representações figurativas, assim como em Nixi $\mathrm{Pae}^{38}$, onde aparecem enfeitando a pele da jibóia (com características humanóides), yuxin que ensina aos Kaxinawá como preparar e consumir a bebida do cipó.

É interessante perceber que, de uma forma ou de outra, kene se fazem presentes em todos os livros de autoria kaxinawá. Mesmo naqueles que não possuem ilustrações, invariavelmente em alguma das fotografias haverá um kaxinawá com algum tipo de adereço enfeitado pelos grafismos.

\title{
4.5. Reflexões finais
}

A associação entre sistemas gráficos produzidos por etnias indígenas e a escrita alfabética parte da constatação de que ambos são sistemas de símbolos não-figurativos que possuem significados específicos através de suas combinações, além de poderem ser inscritos em artefatos e corpos. Portanto, esta não é uma exclusividade da cultura kaxinawá, existindo também para outras etnias indígenas ${ }^{39}$.

Contudo, além de compartilhar, em partes o nome com a escrita alfabética (nawan kene), Lagrou pontua que o kene possui uma conexão mais profunda com o sentido de linguagem e, consequentemente, com os conceitos de conhecimento e poder. Tal constatação é feita pela autora a partir da afirmação de uma anciã kaxinawá: o kene é "a língua dos yuxin" (LAGROU, 2007, pgs. 119-20).

\begin{abstract}
Deste modo, kene e as questões que evoca nos levam diretamente para o campo de discussão sobre a ate e o que exatamente a arte comunica. A arte não se expressa do mesmo modo que a linguagem verbal o faz, porque se o fizesse, não precisaríamos da expressão artística. É pelo motivo de a arte comunicar algo diferente da língua falada - e cada arte o faz de maneira específica - que o artista não pode explicar ou traduzir em palavras o que acabou de comunicar em imagens, sons ou gestos. (LAGROU, 2007, p. 120)
\end{abstract}

De forma semelhante ao que Souza (2006; 2001) e Thiago (2007) pontuam a respeito do "texto multimodal", os conteúdos dos livros analisados são construídos a partir da interação entre elementos pictóricos e elementos verbais, e ambos representam, cada qual a seu modo, aspectos e dimensões distintas, mais ou menos visíveis, da cultura kaxinawá.

Ainda segundo Souza (2001), os kene, compreendidos a partir de sua origem cosmológica enquanto o fruto da transformação sofrida por Yube após ser seduzido pela mulher-jibóia, carregam consigo a possibilidade performática da transformação e transfiguração. Eles assinalam o caminho temporal feito até essa narrativa fundamental e todas as transformações seguintes pelas quais os próprios kaxinawá passaram enquanto povo. Os kene representam, ao mesmo tempo, a morte e a sobrevida, o que pode ser tratado em paralelo com as inúmeras transformações sofridas pela etnia a partir do "tempo das correrias" (KAXINAWÁ, et al., 199-) - as muitas mortes, transformações e sobrevidas.

37 Como visto nas figuras 145 e 146, na página 150.

38 Como visto na figura 163, na página 158.

39 Por exemplo, para os Kayapó-Xilkrin, Assuri e Siona (VIDAL, 1992, apud LAGROU, 2007, p. 119). 


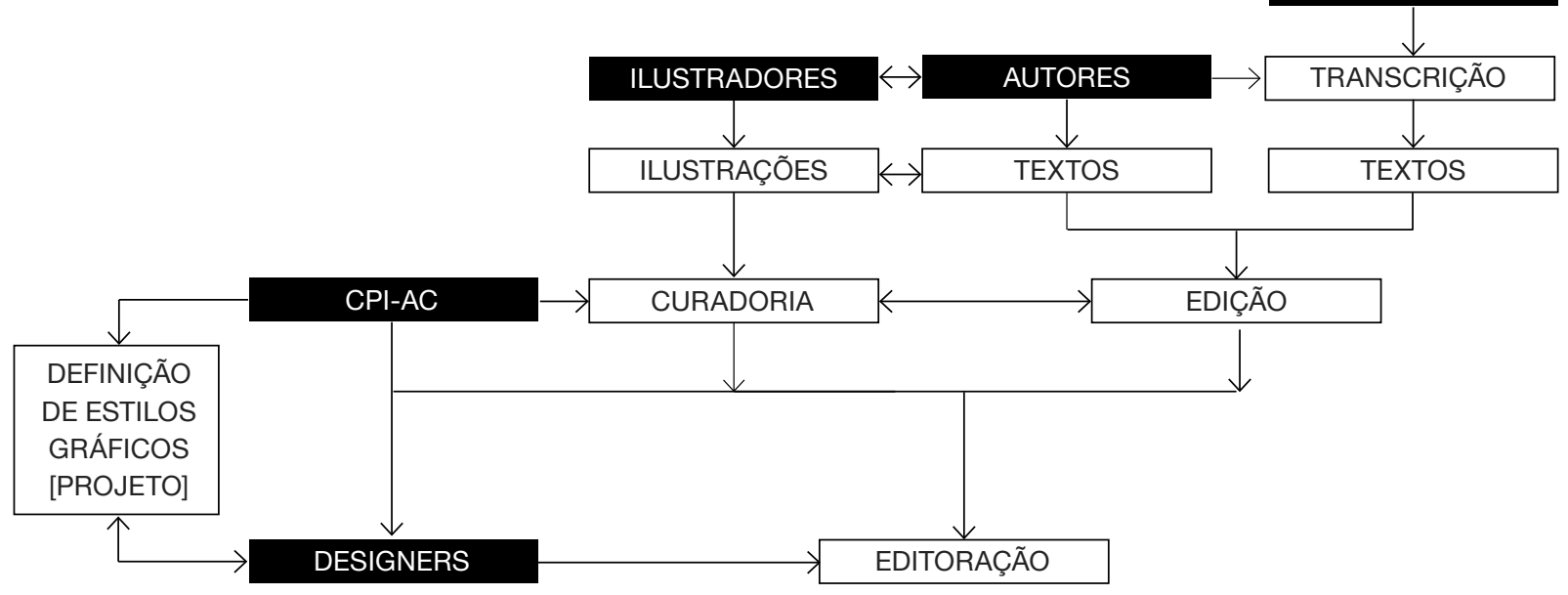

Figura 221: Esquema de agentes e processos de configuração dos livros da Coleção Autoria Indígena. Fonte: Adaptação da autora.
A valorização e codificação dos desenhos kenê fazem com que esses grafismos sejam usados também como marcadores de veracidade e legitimação. Assim, os desenhos kenê num texto indicam a presença nesse texto de algo semelhante a um processo, uma transformação valorizada, e indicam, portanto, que tal texto possui um alto grau de legitimação e veracidade. (SOUZA, 2001, s/p.)

Por outro lado, os os dami (ou seja, os elementos pictóricos figurativos que foram analisados anteriormente) são elementos que representam figurativamente os resultados dessas transformações, sendo, assim, "figuras não codificadas e livres" (SOUZA, 2001, s/p.). O dami representa ou re-apresenta, estando no lugar de algo ou alguém (Ibid.).

As narrativas multimodais kaxinawá se portam, então, como uma versão condensada, materializada, do cruzamento entre várias narrativas: aquela de fato explorada pelo elemento verbal do texto e aquelas trazidas pelos elementos pictóricos. Elas representam uma memória compartilhada, preservada e celebrada através de tudo que é feito por seus representantes. A memória é um conceito que já foi mencionado diversas vezes no decorrer desta dissertação, até então sempre relacionado aos conteúdos textuais e temáticos publicados nos livros da Coleção. Só agora, frente à compreensão mais aprofundada da lógica específica de significação da visualidade kaxinawá, tornou-se possível alcançar, em nível mais complexo, o papel que a memória exerce em todas as dimensões de comunicação (pictórica ou verbal) dos autores kaxinawá.

A memória é prerrogativa de todas as coletividades, uma noção referente ao ato das sociedades de comunicar as suas particularidades no tempo, portanto, é uma construção individual e coletiva de identidades. (...) A memória é social, mas não exclusivamente humana, porque a transmissão daquilo que se busca lembrar depende de fatores técnicos, sejam eles corporais (dependente dos sentidos), sejam aqueles diretamente associados às tecnologias de comunicação e informação. Sendo assim, a memória é um ato resultado de um emaranhado de relações entre pessoas (humanos) e não humanos (objetos, coisas, etc.). (VIEIRA NETO, PEREIRA, 2007, p. 52)

Maria Inês de Almeida, pesquisadora que trabalha com a edição de livros de autoria indígena desde meados da década de 1990, afirma que: "a literatura indígena contemporânea tem sua entrada na cultura do impresso 
com a força de projeto gráfico, com todas as implicações semânticas que esse termo composto e decomposto pode invocar" (ALMEIDA, 2017, p. 64). Segundo a autora, "a página do livro indígena é um cenário, um teatro" (Ibid.) que, através de sua composição e dos elementos pictóricos, verbais e esquemáticos utilizados, não constitui uma representação, metáfora, para os conteúdos que ali estão. O livro, a partir do momento que é escrito, torna-se uma "transformação concreta", "um ser vivo", uma nova forma de interação com os aspectos específicos da cultura ali registrada (Ibid.).

Para a pesquisadora, editar estes livros, assim como a própria escrita indígena, é uma "experiência tradutória". A escrita verbal traduz a oralidade, e o livro busca traduzir a perfomatividade que lhe é fundamental, atuando como espaço de interação e recriação de sentidos (ALMEIDA, 2017). Esta visão vai de encontro com o conceito de tradução intersemiótica explorado por Plaza:

Tradução como prática crítico-criativa na historicidade dos meios de produção e reprodução, como leitura, como meta-criação, como ação sobre estruturas eventos, como diálogo de signos, como síntese e reescritura da história. Quer dizer; como pensamento em signos, como trânsito dos sentidos, como transcriação de formas na historicidade. (PLAZA, 2003, p. 14)

Nos livros produzidos pela CPI-AC, este processo de autoria-criação-tradução é construído como uma complexa rede de agentes, que exercem papeis complementares e diferentes dentro do processo de composição dos livros. Todas as representações e os conteúdos produzidos passam por estágios de configuração que envolvem estes diferentes agentes, e tais agentes possuem leituras distintas daquilo que está sendo feito - a leitura é sempre distinta a partir do leitor, e é imprescindível no processo de tradução (PLAZA, 2003).

Inserido nesta teia, o responsável pelo design ${ }^{40}$ dos livros precisa organizar o conjunto de dados, referências, conteúdos e identidades que devem ser computadas e interpretadas. Deve-se processar um quadro de identidades que se combinam: a identidade dos autores, a identidade dos usuários, a identidade da própria CPI-AC.

Tratando neste momento especificamente dos livros produzidos por designers, que não faziam parte da equipe da CPI-AC, o contato dos mesmos se deu de modo direto com os coordenadores dos projetos, e não envolveu os professores autores. Há de se questionar se, devido a este desequilíbrio, tais livros não, consequentemente, exploram mais a identidade institucional da própria CPI-AC do que a dos autores. Especialmente nos livros que não possuem ilustrações, um pouco da referência autoral dos conteúdos se perde na tradução intersemiótica dos textos ou cantos. Por outro lado, há de se considerar até que ponto é interessante que a combinação entre ilustração e texto se torne um "modelo" ou "receita" única a ser seguida por todos os livros de autoria indígena.

Outra questão que emerge é a utilização dos kene, quando inseridos pelos editores e designers como elemento gráfico utilizado. Apesar de serem uma importante e significativa representação visual kaxinawá, há de atentar-se para que seu uso nos projetos gráficos não ocorra de modo simplista,

40 Optou-se por neste momento por não utilizar o termo "designers", já que nem todos os livros foram produzidos por tais profissionais. Ainda assim, os livros são frutos de processos que utilizaram do design enquanto ferramenta de planejamento construção e atribuição de identidades e significados, até então alheios à natureza intrínseca do que se pretendia produzir (CARDOSO, 2016). 
MANIFESTAÇÕES MATERIAIS

REPRESENTAÇÕES VISUAIS

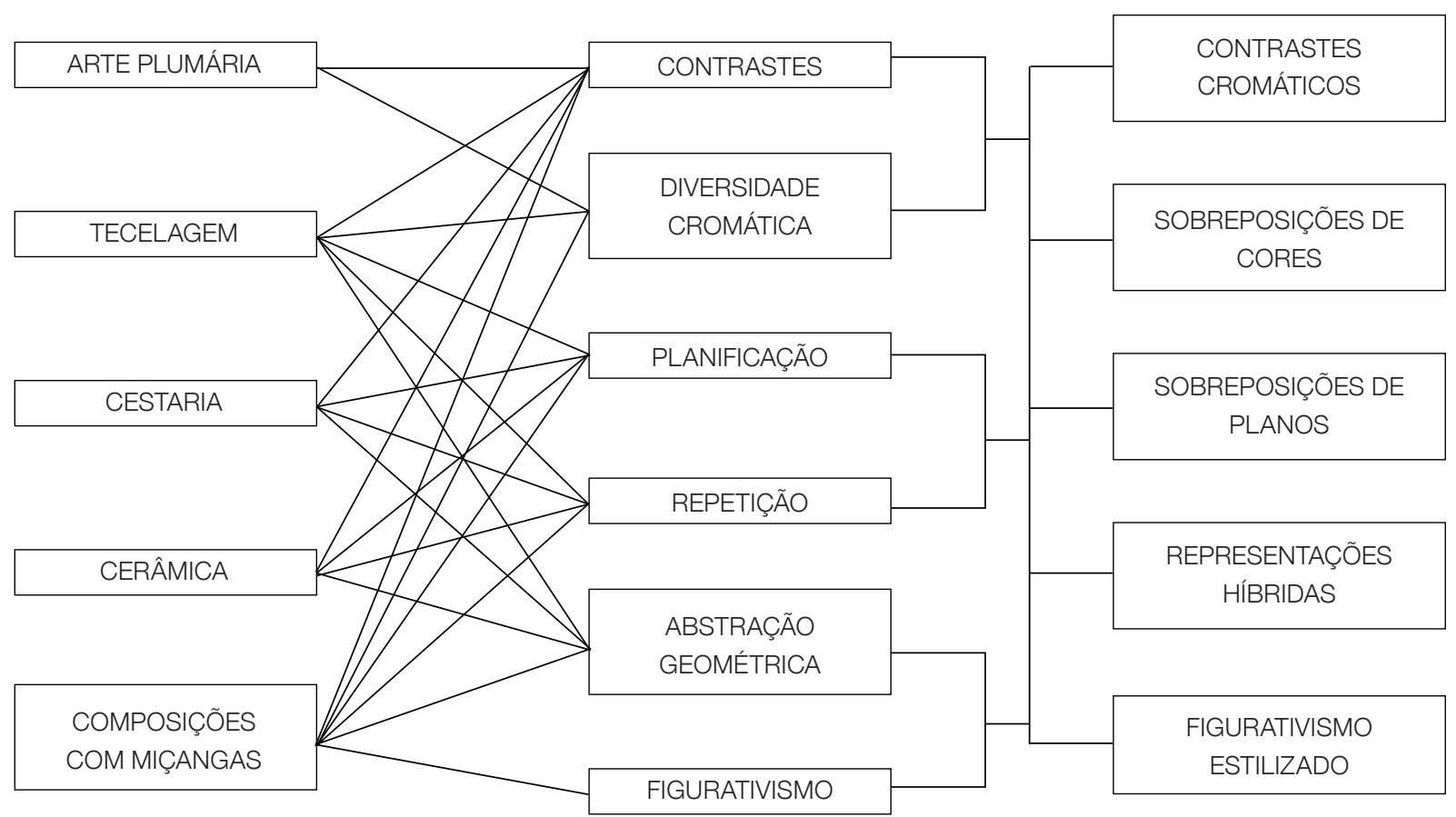

Figura 222: meramente gráfico, correndo o risco do esvaziamento de seus significados Manifestações materiais e representações visuais da arte e ilustração kaxinawá. Fonte Adaptação da autora e, consequentemente, de uma abordagem folclórica dos elementos que constituem as culturas indígenas. Em suma, os kene são elementos pictóricos que possuem significados intrínsecos à sua configuração visual, e devem ser abordados como tal, e não como elementos esquemáticos: grafismos que não possuem valor interpretativo.

Tipografias que remetem ao fazer caligráfico também são comumente utilizadas para representar o fazer manual que acompanha a produção dos livros. Apesar de funcionar bem enquanto metáfora, pensar novas possibilidades pode também ser interessante, no sentido de enriquecer a tradução intersemiótica, alimentando-a com novos símbolos e representações.

A versal utilizada na capa de Shenipabu Miyui, por exemplo, traça uma relação interessante. A fonte deriva de antigas inscrições gregas, que remetam ao próprio nascimento da escrita alfabética com caracteres latinos (BRINGHURST, 2005), relacionando-se, simbolicamente, com o "nascimento" da escrita alfabética indígena pós-colonial.

Desse modo, na tentativa de contribuir para novas possibilidades gráficas que possam ser exploradas em projetos gráficos de livros de autoria kaxinawá indo além das representações já comumente utilizadas, mas que ainda possam apoiar-se nas manifestações culturais dessa etnia, apresenta-se a seguir uma síntese dos principais aspectos estéticos explorados nas produções visuais (dami e kene) e na arte kaxinawá de modo geral, de acordo com os estudos de Lagrou ${ }^{41}(1991,2007)$.

Conforme descrito na análise dos elementos pictóricos, as ilustrações kaxinawá apresentadas nos livros produzidos pela CPI-AC possuem áreas bem delimitadas de cor, geralmente circundadas por contornos expressi-

41 Pra aprofundar-se nos aspectos minuciosos da morfologia e composição dos kene, ver Lagrou (1991). O completo levantamento realizado pela autora motivou a opção pelo não aprofundamento destes aspectos na presente pesquisa. 
vos e orgânicos. A planificação dos elementos é comumente utilizada e as cenas são pensadas em planos que se combinam ou sobrepõem. Não há uma preocupação em fixar o ponto de vista de quem olha, e as perspectivas se misturam na combinação dos planos visuais que compõem as cenas, geralmente pensadas enquanto micronarrativas. "A visão é concebida como um processo dinâmico, e nunca passivo ou estático" (LAGROU, 2002). A sobreposição de planos é muito presente, resultando em imagens que se misturam. Tais sobreposições tem significados diferentes de acordo com o contexto da ilustração: às vezes significam a união de pessoas e/ou animais, às vezes delimitam a profundidade das cenas retratadas.

Outro aspecto interessante que se pode relacionar à sobreposição é a sobreposição de cores causada pela técnica de impressão utilizada. Apesar desta característica não estar diretamente relacionada à forma como os professores produzem as ilustrações, ela influencia na sua apreensão pelos leitores, e é um exemplo de como características compositivas das ilustrações podem se manifestar graficamente.

Os temas variam entre pessoas e tudo aquilo que faz parte da vida da floresta: plantas, animais, artefatos diversos, casas, rios etc. A vida na cidade também é representada, embora não tão comumente. Abstrações misturam-se às representações figurativas, e os níveis de detalhe podem variar, mesmo dentro de uma mesma ilustração. Ainda assim, o caráter etilizado e sintético é significativo, há uma tendência a abstração e abordagem mais interpretativa de escalas, perspectivas e cores.

O contraste também é fundamental na composição dos kene, que exploram, fundamentalmente, a relação entre figura e fundo, e a consequente confusão entre os dois. Os kene podem ser combinados para formar verdadeiras armadilhas perceptivas, labirintos onde o observador pode se perder ou se encontrar (LAGROU, 2007).

A arte kaxinawá manifesta, de vários modos, sua visão intrinsicamente relacional do mundo. Elementos "soltos" são raros em arranjos visuais (e aparecem nos livros apenas quando recortados de suas composições originais, o que pode ser uma opção questionável de acordo com o contexto). Nas composições com kene, não há linhas soltas, "em todo bom desenho, as linhas tem que se tocar" (LAGROU, 2007, p.74).

Os contrastes cromáticos e a riqueza das paletas de cor também são pontos importantes, compartilhados pelas várias manifestações artísticas kaxinawá, tais como as ilustrações aqui abordadas, e a arte plumária e a tecelagem, conforme apontado por Lagrou $(1991,2007)$.

Alteridade e identidade

As relações intersemióticas entre os livros e os outros objetos produzidos pelos índios, entre os livros dos índios e os dos brancos, entre os textos antigos e os modernos, entre os textos audiovisuais e os impressos, acabarão por produzir novos espaços de inclusão - fricções interculturais - mais adequados à pluralidade da sociedade brasileira. Quanto mais se vê, mais se conhece, e mais se ama: essa lógica ideal justifica o esforço de publicação dos textos indígenas. (ALMEIDA, 2014, p. 20)

A concepção da "identidade" para os Kaxinawá é construída através de complexos processos de reconhecimento e fascínio pela alteridade: "por meio de recorrentes inversões de papéis e posições no sistema de nominação e no ritual, e através dos persistentes paradoxos elaborados pelo discurso, a questão da identidade e alteridade aparece como tema central na ontologia kaxinawá" (LAGROU, 2002, p. 29). 
Assim como outras dualidades fundamentais da cosmologia dessa etnia, a compreensão da semelhança e da diferença são encaradas como opostos de um mesmo par, sendo cada metade parte constituinte da outra, assim como do total. Não se trata de um sistema classificatório, mas sim relacional.

Com base nessa percepção, Lagrou (2007) concebe o conceito de identidade kaxinawá em graus posicionados entre os pólos opostos de "eu" e "outro", com vários níveis intermediários de "não-eu" e "não-outro", onde se posicionam parentes, amigos, estrangeiros, inimigos. O extremo do "outro" é, ao mesmo tempo, temido e desejado, já que, do contato com o não-outro pode advir tanto a destruição quanto a construção de novos conhecimentos.

Como no mito da anaconda/jibóia, a ética de "abertura para o outro" leva os Kaxinawá a apreender a alteridade radical como algo perigoso e ao mesmo tempo desejável, um paradoxo insolúvel, onde não há outra possibilidade a não ser permitir-se tornar-se outro. Assim, nesse processo de "abertura para o outro", no contato desejável com a alteridade externa, o Kaxinawá é levado a penetrar no mundo do outro; uma vez nesse mundo da alteridade, isolado e distante de seu lar, ele se deixa transformar no outro. Uma vez transformado, ele por sua vez transforma o que adquiriu da alteridade, domesticando-a; uma vez dominada e domesticada a alteridade, o Kaxinawá já pode retornar, levando-a para o lar. Tal é a dialética da alteridade ameríndia - onde o sujeito se transforma em objeto (Outro) e novamente em sujeito; dessa vez em um sujeito transformado e não no mesmo sujeito inicial. (SOUZA, 2001, s/ p.)

Assim como para outros povos ameríndios, o conhecimento, a memória e a arte são "encorporadas" pelos Kaxinawá. Há uma preocupação significativa em delimitar e produzir corpos que possam fixar e materializar identidades que constituem o "eu" kaxinawá, que inclui não só o seu próprio corpo, como também os de seus parentes próximos, e os artefatos que o cercam, entendidos como extensões de seus corpos, e que possuem um papel fundamental nas interações sociais (LAGROU, 2007, p. 38).

Vale a pena chamar atenção aqui para o fato de a maior parte dos povos ameríndios atribuírem a inspiração para sua arte, desde a matéria-prima aos aprendizados dos grafismos de pintura corporal e facial e motivos tecidos em cestarias ou redes, a conquistas sobre inimigos. Estes inimigos podem ser desde povos humanos vizinhos a seres sobrenaturais como a jibóia/sucuri mítica, responsável entre a grande maioria dos povos amazônicos pelos motivos usados na cestaria, tecelagem e pintura. (LAGROU, 2007, p. 78)

Lagrou (2007) utiliza-se da miçanga como metáfora para explorar a "materialização ou imaginação das várias faces da alteridade pelos kaxinawá" (LAGROU, 2007, p. 77). Advindas de seu principal "inimigo", o homem branco, colonizador e representante de um "mundo externo", a utilização das miçangas como matéria-prima para a confecção de colares ${ }^{42}$ e adere-

42 O uso de colares feitos com contas de origem natural já era realizado pelos Kaxinawá antes do contato com o homem branco (LAGROU, 2007). 


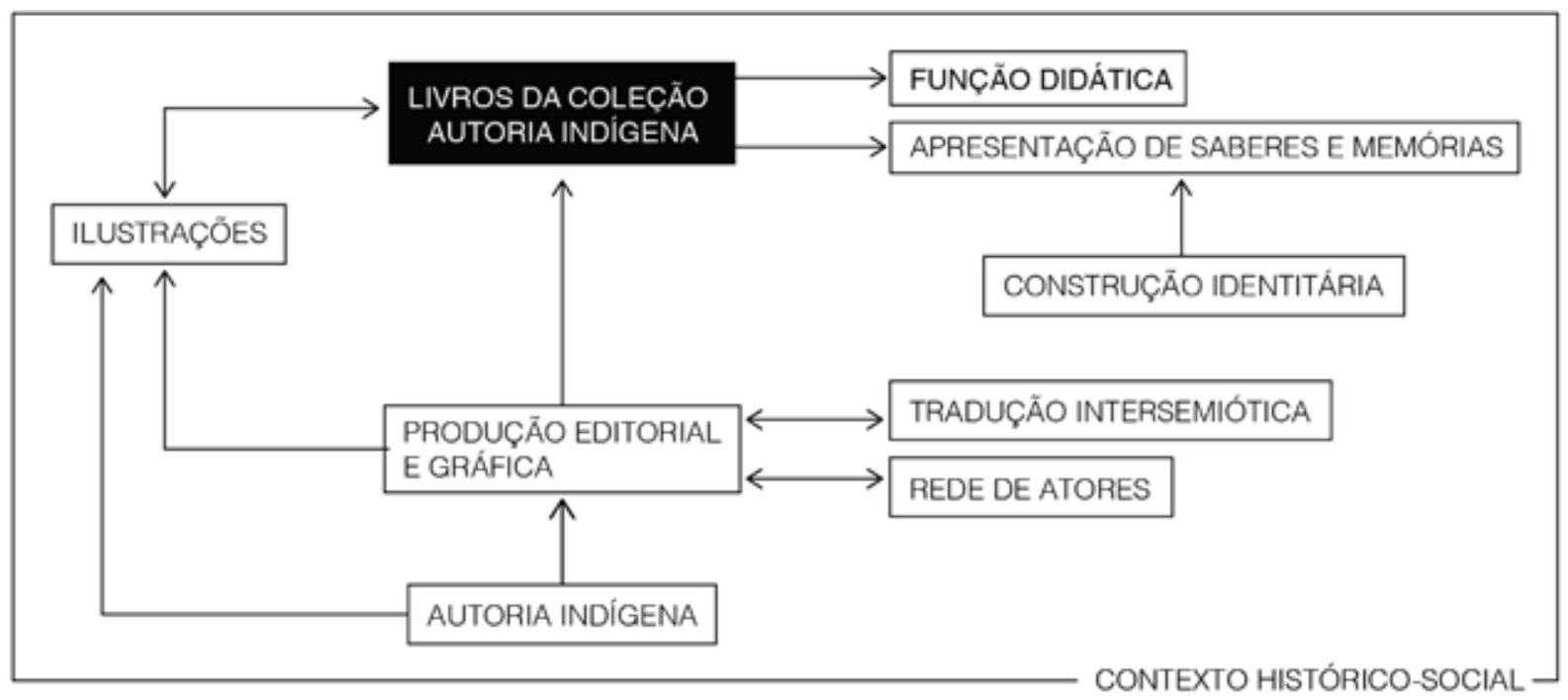

ços com motivos tradicionalmente kaxinawá invoca e materializa a relação com este outro mundo, e as formas pelas quais ele passou a fazer parte, também, do mundo kaxinawá (Ibid.).

Os kaxinawá valorizam a característica estética dos artefatos em geral, assim como de seus próprios corpos. É desejável enfeitar-se com adereços e vestimentas tecidos em algodão ou miçangas. Por outro lado, "mais importante que as coisas em si é o conhecimento de como fazer as coisas" (LAGROU, 2007, p. 81). Objetos e artefatos são vistos como interessantes por materializarem o conhecimento necessário para sua manufatura, e nem tanto como coisas para serem acumuladas e possuídas (Ibid.).

Da mesma forma, se pode tentar transferir algumas dessas relações para os livros em foco nesta análise. A escrita alfabética, inicialmente utilizada pelo colonizador como um instrumento de dominação e controle dos povos indígenas, foi desejada e, quando finalmente incorporada, é agora usada como instrumento de autonomia, valorização e manutenção cultural. Ao entrar em contato com o que lhe é alheio, e assumindo suas características como parte de si próprios, sua própria identidade é aumentada.

Os livros, artefatos que não fazem parte da cultura material tradicional kaxinawá, são incorporados através do uso de suas representações visuais, kene e dami, dos conteúdos escritos em hãxta kũ̃, ou mesmo que em português, produzidos por kaxinawás e que representam sua cultura. São importantes manifestações e extensões dos indivíduos que os produzem. Todavia, mais importante que os livros em si são os conhecimentos que ali estão. Seja o conhecimento necessário para escrevê-los, em termos do domínio da escrita, ou em termos de "conhecer" o que está sendo descrito ali (conhecer seus cantos, plantas, técnicas tradicionais).

"Práticas tradicionais configurando sujeitos novos, práticas novas fazendo re-emergir sujeitos tradicionais, enfim, uma intricada rede de possibilidades, que não pode ser abordada, jamais, a partir de uma simples oposição entre o tradicional e o "novo'" (GALLOIS, 2007, p. 99). Dessa forma, não é o caso de se pensar em termos de o que seria mais "adequado" ou receitas prontas para guiar o desenvolvimento do design dos impressos de autoria indígena kaxinawá, e não foi este o objetivo desta análise. A intensão geral, aqui, foi buscar explorar as representações e relações que compõem as poéticas visuais e gráficas kaxinawá, e que podem ser utilizadas na configuração das textualidades a partir das quais livros são feitos: escrita alfabética, diagramação, desenho, cor. 
Figura 224: Obra de

Isaías Ibã. Fonte: Blog do artista. Disponível em $<$ ttp://nixi-pae.blogspot. com> (acesso em janeiro de 2020).

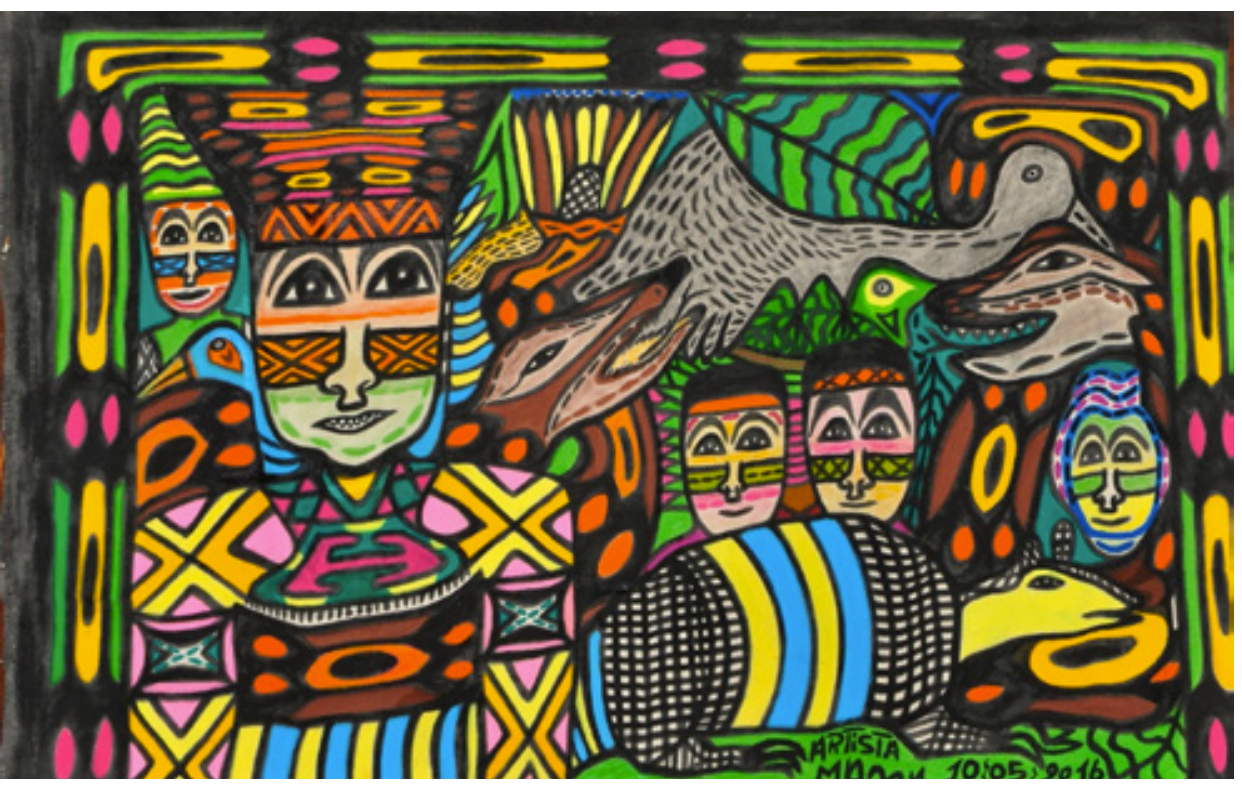

Os artistas Huni Kuĩ e a arte contemporânea

O MAHKU, Movimento dos Artistas Huni Kuĩ, é um coletivo artístico que teve início com as pesquisas realizadas por Ibã Isaías Sales para compor o livro Nixi Pae - O Espírito da Floresta, publicado em 2006 pela CPI-AC. Ibã escreveu e ilustrou o livro, fruto de um levantamento realizado com seu pai e outros anciãos a respeito das músicas cantadas no ritual de consumo do cipó (ayahuasca).

Se no livro Ibã ilustra a narrativa tradicional da origem do cipó, com o desenvolvimento de sua pesquisa ele expandiu sua atuação artística e passou a produzir desenhos que representam as músicas em si, assim como o ritual e os efeitos da bebida sagrada.

O coletivo começou em 2011, e é formado, basicamente, por Ibã e seu filho, Bane. Acompanhados pelo professor Amilton Pelegrino de Mattos, professor da Licenciatura Indígena e orientador de Ibã, os três realizam um projeto de pesquisa a respeito dos cantos e de sua produção artística pela UFAC. Atualmente, o coletivo possui uma sede, o Centro MAHKU Independente, localizada na TI do Rio Jordão.

Em vídeos ${ }^{43}$ onde registram e relatam sua produção, Ibã e Bane contam que as imagens que compõem suas telas e desenhos são as "mirações", aquilo que se vê sob o efeito do cipó e com a entonação dos cantos sagrados. Em suas criações, cores, animais, pessoas e formas se misturam e se transformam.

O coletivo já expôs em várias cidades brasileiras e em Paris, na Fundação Cartier para a Arte Contemporânea, organizaram dois encontros de artistas kaxinawá, e também ministram oficinas e aulas de desenho onde compartilham seus conhecimentos (MATTOS, HUNI KUĨ, 2017). Em novembro de 2019 ministraram o módulo de artes e ofícios da formação de AAFIS na CPI-AC ${ }^{44}$, fechando o ciclo que se iniciou em 1983, quando Ibã participou do primeiro curso de formação de professores da instituição.

43 "Espírito da floresta 1", disponível em < https://www.youtube.com/watch?v=zRlbRpoiOcQ >; "Espírito da floresta 2", disponível em < https://www.youtube.com/watch?v=pIo90b2qGDI > e "O sonho do nixi pae - o movimento dos artistas huni kuĩ", disponível em < https://www.youtube.com/watch?v=O_eEa3FBTec > (acesso em janeiro de 2020).

44 Fonte: "Artes e Ofício: Agentes Agroflorestais Indígenas trazem em suas telas os Espíritos da Floresta". Notícias da CPI-AC, publicado em 06/11/2019. Disponível em < http:// cpiacre.org.br/conteudo/2019/11/06/artes-e-oficio-agentes-agroflorestais-indigenas-trazem-em-suas-telas-os-espiritos-da-floresta > (acesso em janeiro de 2020). 


\section{Considerações finais}

Os livros da Coleção Autoria Indígena foram produzidos e publicados com um importante objetivo: para além de seus potenciais didáticos, ao incentivar e exercitar a aquisição de conhecimentos, da escrita e leitura dos alunos, os livros apresentam os saberes, histórias e memórias de culturas que foram, por tanto tempo, silenciadas, finalmente contadas de uma perspectiva interna, própria.

A autoria indígena dos livros é representada visualmente, em grande parte, pelas ilustrações utilizadas. Elas ditam o tom da configuração gráfica da Coleção e preenchem boa parte das páginas de todos os livros produzidos pela CPI-AC até o início dos anos 2000 (2002, para afirmar com exatidão).

Praticamente todos os textos que tratam a respeito dos livros da Coleção informam, em um primeiro momento, que os livros resultam de um projeto de educação diferenciada, e que seus conteúdos eram desenvolvidos em conjunto durante as aulas dos cursos de formação de professores indígenas que a CPI-AC promoveu entre 1983 e 2008.

Durante a realização desta pesquisa ficou claro que, da mesma forma, a elaboração dos livros da Coleção foi, em si mesma, uma grande formação pela qual os autores indígenas e os membros da equipe da CPI-AC passaram. Enquanto os primeiros expandiram sua atuação enquanto autores, dominando a prática da escrita, os segundos aperfeiçoaram-se como editores e diretores de arte. Os métodos editoriais aplicados pela entidade foram desenvolvidos concomitantemente à produção das publicações, o que teve implicações diversas. Se, por um lado, a não-padronização de tais métodos causou algumas inconsistências formais e problemas técnicos, por outro, também propiciou uma grande capacidade de adaptação, que permitiu a superação das muitas dificuldades (técnicas, financeiras etc) encontradas.

$\mathrm{O}$ caráter cambiante dos métodos editoriais da CPI-AC também parece estar mais ajustado à "definição indeterminada" do conceito de autoria indígena: complexo, às vezes dúbio e repleto de questionamentos. A compreensão do conceito desenvolveu-se em sincronia com os métodos editoriais e com a própria evolução da instituição e de suas ações, estando todos estes em constante redefinição: em estado fluido.

A configuração visual dos livros da Coleção Autoria Indígena reflete todos estes processos, assim como vários aspectos do contexto histórico e social no qual sua produção se insere. Essa multiplicidade cultural, conceitual e metodológica, se manifesta de modos diversos, relacionando-se tanto às representações visuais utilizadas, quanto aos métodos aplicados na composição de tais representações.

Com o estudo aprofundado da configuração gráfica dos livros de autoria kaxinawá, observados a partir da compreensão de aspectos fundamentais da concepção artística desta etnia, pode-se compreender alguns dos caminhos semânticos que os autores, ilustradores, editores e designers percorrem para chegar na formatação de determinado conteúdo. O caminho, assim como o kene kaxinawá, é labiríntico e, muitas vezes, confuso, pois envolve uma série de traduções, representações, metáforas visuais e relações culturais de identidade e alteridade. 
O profissional em design gráfico lida constantemente com os conflitos e desafios inerentes à configuração do espaço visual da sociedade na qual está inserido. No caso dos livros de autoria indígena, faz-se necessário atenção redobrada. $O$ posicionamento ético perante as relações estéticas que são construídas graficamente é fundamental para que não se caia na armadilha de, ao assumir padrões e representações considerados comuns na cultura não-indígena, reproduzir relações hegemônicas de poder e subordinação cultural. Para tanto, é necessário compreender os conceitos culturais específicos de cada cultura, e respeitar a autonomia dos autores.

Se há uma crítica que pode ser feita à produção dos livros da Coleção Autoria Indígena, esta diz respeito à maior participação dos professores e autores no processo de configuração visual e editorial dos livros. Apesar de não se interessar pela definição de um método único para o desenvolvimento dos livros, também parece não haver muito interesse em explorar as relações entre os designers e os autores, experimentando novos processos e possibilidades.

De todo modo, pode-se mapear muitas articulações entre as características gráficas dos livros de autores kaxinawá e as manifestações visuais e artísticas tradicionais de sua cultura. Para próximas pesquisas, pode ser interessante aprofundar-se nas possibilidades de tratamento gráfico que abordem estas articulações de modo mais metodológico, intencional e direto.

Enfim, assim como o projeto pedagógico da CPI-AC e das escolas indígenas se propõem a abraçar as disparidades e tensões que fazem parte elementar das relações entre as sociedades indígenas e não-indígenas, a configuração visual dos livros da Coleção Autoria Indígena baseia-se no equilíbrio entre muitos pólos: a oralidade e a escrita, as manifestações visuais tradicionalmente indígenas e as não-indígenas, a criatividade e a repetição, a representação e a abstração, a transformação e a estabilidade.

Transformações permeiam todos os processos e questionamentos levantados por esta pesquisa. Do mesmo modo que os livros da Coleção se transformam e reconfiguram com o passar do tempo, as culturas indígenas, ao contrário do que a visão hegemônica e colonizadora pode querer fazer crer, também passam por constantes movimentos de metamorfose e ressignificação, marcados pela criatividade que lhe é característica. Ao buscar compreender e acompanhar tais processos, o design gráfico se mantém fiel ao caráter interdisciplinar que é inerente à sua configuração enquanto área de conhecimento, e ao seu importante papel enquanto agente crítico e reflexivo de mudança, capaz de projetar e transformar as relações sociais e estéticas que compõem a visualidade. 


\section{Referências}

ALMEIDA, M. I. de. Editar livros com os índios: caminhos do pensamento vivo. Boitatá - Revista do GT de Literatura Oral e Popular da ANPOLL, $n^{\circ}$ 24. Londrina: 2017.

. O caminho de um pensamento vivo e a estética orgânica - a escola indígena, a partir da experiência literária. Revista Patrimônio e Memória, v. 10, $\mathrm{n}^{\circ}$ 2, julho-dezembro. São Paulo: Unesp, 2014. Pgs. 17-34.

AQUINO, T. T. V. de; IGLESIAS, M. P. Kaxinawá do Rio Jordão: história, economia e desenvolvimento sustentado. Rio Branco: Comissão Pró-índio do Acre, 1994.

Habitantes: os Kaxinawá. In: CUNHA, M. C. da; ALMEIDA, M. B. de (orgs.). Enciclopédia da floresta. São Paulo: Companhia das Letras, 2002. Pgs. 147-160.

BAUER, M. W. Análise de conteúdo clássica: uma revisão. In: BAUER, M. W.; GASKELL, G. (orgs.). Pesquisa qualitativa com texto, imagem e som: um manual prático. Petrópolis: Vozes, 2011.

BERGAMASCHI, M. A.; MEDEIROS, J. S. História, memória e tradição na educação escolar indígena: o caso de uma escola Kaingang. Revista Brasileira de História, São Paulo, v. 30, n 60, 2010. Pgs. 55-75.

BONSIEPE, G. Design, Cultura e Sociedade. São Paulo: Blucher, 2011.

. The uneasy relationship between design and design research. Design Research Now. Birkhauser: Basel, 2007. Pgs. 25-39.

BRINGHURST, R. Elementos do estilo tipográfico. São Paulo: Cosac Naify, 2008.

CABRAL, A. S. A. C. et alii. Por uma educação indígena diferenciada. CNRC/FNP: Brasília, 1987.

CARDOSO, R. Design para um mundo complexo. São Paulo: Ubu Editora, 2016.

CENTRO ECUMÊNICO DE DOCUMENTAÇÃO E INFORMAÇÃO - CEDI. Alfabetização e primeiras contas: experiências na elaboração de material didático para adultos. Cadernos do CEDI, n 13. São Paulo: CEDI, 1984.

COLLI, J.; PAIVA, R. M.; DUTRA, T. L. M.; TORRES, C. L.; FONSECA, L. P.; PACHECO, H. S. Metodologia desenvolvida por núcleo de pesquisa em design da Ufes para a análise gráfica da revista Vida Capichaba. Anais do Simpósio de Pesquisa e Extensão em Design - Simpex, v. 1. Vitória: 2011.

COMISSÃO PRÓ-ÍNDIO ACRE. Quem Somos. S/d. Disponível em <http//:www. cpiacre.org.br>. Acesso em maio de 2018.

DINIZ, K. Notas sobre tipografias para línguas indígenas do Brasil. InfoDesign Revista Brasileira de Design da Informação, n 4, vol. 1, 2007, pg. 36-46.

FLICK, U. Introdução à pesquisa qualitativa. Porto Alegre: Penso/Artmed, 2009.

FULGÊNCIO, C., U. Índias do Acre levam artesanato a Nova Iorque. G1 do Acre, Rio Branco, 19 de abril de 2013. Disponível em <http://g1.globo.com/ac/ acre/noticia/2013/04/indios-do-acre-levam-artesanato-nova-iorque $>$, acesso em janeiro de 2020. 
GAVAZZI, R. A. Por uma estética orgânica. Samaúma - Revista da AMAAIAC, ${ }^{\circ}$ 1, 2017. Pgs. 34-39.

GAVAZZI, R. A.; RESENDE, M. S. (orgs.). Atlas geográfico indígena. Rio Branco: Comissão Pró-Índio do Acre, 1996.

Geografia indígena. Rio Branco: Comissão Pró-Índio do Acre, 1992.

GALLOIS, D. T. Materializando saberes imateriais: experiências indígenas na Amazônia Oriental. Revista de estudos e pesquisas, v. 4, n 2. Brasília: FUNAI, 2007. Pgs. 95-116.

GALLOIS, D. T.; KLEIN, T.; DAL'BO, L. Povos Indígenas, políticas multiculturais e políticas da diferença. Revista Cultura e Extensão USP, $n^{0} 15$. São Paulo: USP, maio de 2016. Pgs. 31-48.

GOMES, A. O. Por uma antropologia dos museus indígenas: práticas de colecionamento, categorias nativas e regimes de memória. $29^{\circ}$ Reunião Brasileira de Antropologia. Natal, 3 a 6 de agosto de 2014.

GOLDSMITH, E. Comprehensibility of illustration: an analytycal model. Information Design Journal, v. 1, n 3, 1980. Pgs. 204-213

GRAÚNA, G. Contrapontos da literatura indígena contemporânea no Brasil. Belo Horizonte: Mazza Edições, 2013.

GRUPIONI, L. D. B. Tempos de escrita. Rio de Janeiro: Museu do índio, 2008.

GRUSZYNSKI, A. C. A Imagem da Palavra. Teresópolis: Novas Idéias, 2007.

. Design gráfico: do invisível ao ilegível. São Paulo: Edições Rosari, 2008.

IBÃ KAXINAWÁ, I. S. Nixi Pae - O espírito da floresta. Rio Branco: CPI-AC, 2006.

INSTITUTO SÓCIO AMBIENTAL - ISA. Direitos constitucionais dos índios. Povos Indígenas no Brasil, s/d., modificado pela última vez em 2018. Disponível em <https://pib.socioambiental.org/pt/Constituiçao>. Acesso em julho de 2018.

. Quem são? Povos Indígenas no Brasil, s/d., modificado pela última vez em 2018. Disponível em <https://pib.socioambiental.org/pt/Quem_são> . Acesso em julho de 2018.

. Organizações indígenas. Povos Indígenas no Brasil, s/d., modificado pela última vez em 2018. Disponível em <https://pib.socioambiental.org/pt/ Organizações_indígenas>. Acesso em dezembro de 2019.

JUSBRASIL. Art. 78 e 79 da Lei de Diretrizes e Bases. Disponível em <https:// www.jusbrasil.com.br/topicos/11683633/artigo-79-da-lei-n-9394-de-20-de-dezembro-de-1996> , acesso em março de 2019.

JULIER, G. From visual culture to design culture. Design issues, Massachusetts, v. $22, \mathrm{n}^{\circ} 1,2006$, pgs. 64-76.

KAXINAWÁ, J. P. M., et alii. Índios no Acre: história e organização. Rio Branco: Comissão Pró-índio do Acre, 199-. $2^{\circ}$ ed.

KAXINAWÁ, J. M.; IGLESIAS, M. P. Huni Kuĩ (Kaxinawá). In: FUNDAÇÃO DE CULTURA E COMUNICAÇÃO ELIAS MANSOUR (FEM). Povos indígenas no Acre. Rio Branco: FEM, 2010. Pgs. 73-79.

KATUKINA, B. A. et alii. Cartilha Katukina. Rio Branco: Comissão Pró-índio do Acre, 1995.

LAGROU, E. A fluidez da forma: arte e agência em uma sociedade amazônica (Kaxinawá, Acre). Rio de Janeiro: Topbooks, 2007. 
Huni Kuĩ (Kaxinawá). Povos Indígenas no Brasil, Instituto Socioambiental, 2004. Disponível em: < https://pib.socioambiental.org/pt/Povo:Huni_Kuin_(Kaxinawá) > . Acesso em janeiro de 2020.

O que nos diz a arte kaxinawá sobre a relação entre identidade e alteridade? Mana, v. 8, $\mathrm{n}^{\circ}$ 1. Rio de Janeiro, abril de 2002. Pgs. 29-61.

Uma etnografia da cultura Kaxinawá: entre a cobra e o inca. Dissertação (Mestrado em Antropologia Social) - Universidade Federal de Santa Catarina, Florianópolis, 1991.

LIMA, A. O livro indígena e suas múltiplas grafias. 2012. Dissertação (Mestrado em Literatura Brasileira) - Faculdade de Letras da UFMG, Programa de pós-graduação em Letras: Estudos Literários, Belo Horizonte, 2012.

LIMA KAXINAWÁ, J. P. de. Nukũ kenu xarabu. Rio Branco: OPIAC/CAPEMA/ CPI-AC, 2006.

LIMA KAXINAWÁ, J. P. de. Uma gramática da língua Hãtxa Kuĩ. Tese (Doutorado em Linguística). Instituto de Letras da Universidade de Brasília, 2014.

MAIA, D. (org.). Kene: a arte dos Huni Kuĩ. Catálogo de exposição. Rio de Janeiro: CNFCP, 1999.

MATEUS, A. M. (org.). O livro vivo. Belo Horizonte: Literaterras/Faculdade de Letras da UFMG, 2012.

MATTOS, A.; HUNI KUĨ, I. Por que canta o MAHKU - Movimento dos Artistas Huni Kuĩ? GIS - Gesto, Imagem E Som - Revista de Antropologia, n² 2. São Paulo, 2017.

MCCALLUM, C. Comendo com Txai, comendo como Txai. A sexualização de relações étnicas na Amazônia contemporânea. Revista de Antropologia, v. 40, n 1. Universidade de São Paulo: São Paulo, 1997. Pgs. 109-148.

. Um copo de cultura: os Huni Kuĩ (Kaxinawá) do rio Humaitá e a escola. Mana, Rio de Janeiro, v. 13, n. 2, 2007. Pgs. 586-588.

MENESES, U. B. de. Fontes visuais, cultura visual, história visual. Balanço provisório, propostas cautelares. Revista Brasileira de História, São Paulo, v. 23, n 45, 2003. Pgs. 11-36.

Rumo a uma História Visual. In: ECKERT, Cornelia; NOVAES, Silvia Caiuby (orgs.). O Imaginário e o poético nas Ciências Sociais. Bauru: EDUSC, 2005. Pgs. 33-56.

Ministério da Educação - MEC. Indígenas reivindicam atenção à educação e combate ao racismo. Assessoria de Comunicação Social, julho de 2016. Disponível em: < http://portal.mec.gov.br/ultimas-noticias/206-1084311476/ 37641-indigenas-reivindicam-atencao-a-educacao-e-combate-ao-racismo > Acesso em janeiro de 2020.

Ministério da Educação - MEC; Instituto Nacional de Estudos e Pesquisas Educacionais Anísio Teixeira - INEP. Diretoria de Estatísticas Educacionais. Educacenso - Um Olhar sobre a Educação Indígena Com Base no Censo Escolar de 2008. Brasília: INEP, 2009. Disponível em <http://portal.mec. gov.br>. Acesso em janeiro de 2020.

MONTE, N. L. Cronistas em viagem e educação indígena. Belo Horizonte: Autêntica Editora: 2008.

(org.). E o jacaré serviu de ponte. Rio branco: Comissão Pró-índio do Acre, 1984. 
Escolas da floresta: entre o passado oral e o presente letrado. Rio de Janeiro: Multiletra, 1996.

. Novos frutos das escolas da floresta. Rio de Janeiro: Nietta Lindenberg Monte, 2003.

MONTE, N. L.; Kaxinawá, J. P. M. (coord.). Shenipabu Miyui - História dos antigos. Rio Branco: Comissão Pró-índio do Acre, 1994.

MONTE, N. L.; SENA, V. O. (orgs.). CPI-AC - Comemorando 22 anos de história. Rio Branco: Comissão Pró-índio do Acre, 2001.

MORAES, R. Análise de conteúdo. Revista Educação, v. 22, n 37. Porto Alegre, 1999. Pgs. 7-32

MORAES, D. C. D. de. Visualidade do livro didático no Brasil: o design de capas e sua renovação nas décadas de 1970 e 1980. Dissertação (Mestrado em Educação). Faculdade de Educação da Universidade de São Paulo, 2010.

MUNDURUKU, D. O caráter educativo do movimento indígena brasileiro (1970-1990). São Paulo: Paulinas, 2012.

MURU, A., et alii. A arte do kene. Rio Branco: Comissão Pró-índio do Acre, 2006.

MURU, A. M. M. I.; QUINET, A. (orgs.). Una Isi Kayawa - Livro da Cura do povo Huni Kuĩ do rio Jordão. Rio de Janeiro: Dantes, 2014.

OCHOA. M. L. P.; WEBER, I. (orgs.). Historia e organização dos Huni Kuĩ do Alto Rio Purus. Rio Branco: CPI-AC, 2013.

OLIVEIRA, A. H. de. Já me transformei: modos de circulação e transformação de pessoas e saberes entre os Huni Kuĩ (Kaxinawá). Dissertação (Mestrado em Antropologia Social). Faculdade de Filosofia, Leras e Ciências Humanas da Universidade de São Paulo, 2016.

PAIVA, R. M.; SOUSA, C. S. M. de. “Coleção Autoria Indígena” da Comissão Pró-índio do Acre: análise gráfica das capas dos livros de leitura. Anais do $9^{\circ}$ Congresso Internacional de Design da Informação (CIDI 2019). Belo Horizonte: Blucher, 2019. Pgs. 2120-2131

PLAZA, J. Tradução intersemiótica. Perspectiva: São Paulo, 2003.

SANTOS, A. do; KISTMANN, B. V.; ONO, M. M. Modelo de referência para a estrutura de Capítulos de dissertações/Teses. In: WESTIN, D.; COLEHO, L. A. L. (orgs.) Estudo e prática de metodologia em design nos cursos de pós-graduação. Rio de Janeiro: Novas Ideias, 2011.

SILVA, P. C. P.; SILVA, S. A. Tipografia e alteridade: notas sobre edições indígenas. Linguagens gráficas, v. 1, n 1 . Rio de Janeiro, 2014. Pgs. 42-56.

SOUZA, L. M. T. M. de. Uma outra história, a escrita indígena no Brasil. Povos Indígenas no Brasil, Instituto Socioambiental, 2006. Disponível em: <https://pib.socioambiental.org/> Acesso em janeiro de 2020.

As visões da anaconda: a narrativa escrita indígena no Brasil. Revista SemeaR, v. 7, Rio de Janeiro: Pontifica Universidade Católica, 2001. Disponível em: <http://www.letras.puc-rio.br/unidades\&nucleos/catedra/ revista/7Sem_16.html>. Acesso em janeiro de 2020.

TODOS PELA EDUCAÇÃO. Anual Brasileiro da Educação Básica 2013. São Paulo: Editora Moderna, 2013.

TODOS PELA EDUCAÇÃO. Anual Brasileiro da Educação Básica 2018. São Paulo: Editora Moderna, 2018. 
THIAGO, E. M. C. P de S. $O$ texto multimodal de autoria indígena: narrativa linear e interculturalidade. Tese (Doutorado em Estudos Lingüísticos e Literários em Inglês) - Faculdade de Filosofia, Letras e Ciências Humanas, Universidade de São Paulo, São Paulo, 2007.

TWYMAN, M. A schema for the study of graphic language. In: KOLERS, P.; WROLSTAD, M.; BOUMA, H. (eds.). Processing of visible language. Plenum Press, v. 1. New York, 1979. Pgs. 117-150

VIEIRA NETO, J.; PEREIRA, E. Povos indígenas no Brasil, museus e memória: questões emergentes. Revista do Centro de Pesquisa e Formação do Sesc, $\mathrm{n}^{\circ}$ 5. São Paulo, 2017.

VILLAS-BOAS, A. Sobre análise gráfica, ou algumas estratégias didáticas para a difusão de um design crítico. Arcos Design, v. 5. Rio de janeiro, 2009. Pgs. 117-150.

\section{Entrevistas}

AQUINO, Terri Vale de. Entrevista concedida à Rayza Mucunã Paiva em 04/07/2019. Registro em áudio. Duração: 153' 42".

GALVÃo, Maurício de Lara. Entrevista concedida pessoalmente à Rayza Mucunã Paiva em 15/07/2019. Registro em áudio. Duração: 43' 57".

FERREIRA, Janio. Entrevista concedida pessoalmente à Rayza Mucunã Paiva em 16/07/2019. Registro em áudio. Duração: 47'.

GAVAZZI, Renato Antônio. Entrevista concedida pessoalmente à Rayza Mucunã Paiva em 22/05/2019. Registro em áudio. Duração: 59' 5".

GOMES SHAMENAWA, Eldo Carlos. Entrevista concedida pessoalmente à Rayza Mucunã Paiva em 07/07/2019. Registro em áudio. Duração: 64' 24".

MAIA, Maria Djacira. Entrevista concedida pessoalmente à Rayza Mucunã Paiva em 23/05/2019. Registro em áudio. Duração: 60'.

NORONHA, Guilherme. Entrevista concedida à Rayza Mucunã Paiva, por Skype, em 29/08/2019. Registro em áudio. Duração: 95'.

SENA, Vera Olinda. Entrevista concedida pessoalmente à Rayza Mucunã Paiva em 23/05/2019. Registro em áudio. Duração: 70'.

TASHKÃ, Joaquim Luiz. Entrevista concedida pessoalmente à Rayza Mucunã Paiva em 16/07/2019. Registro em áudio. Duração: 37' 13".

TEIXEIRA, Gleyson de Araújo. Entrevista concedida pessoalmente à Rayza Mucunã Paiva em 18/07/2018. Registro em áudio. Duração: 60'.

Trechos expandidos das entrevistas estão disponiveis em:

$<$ http:/livroskaxinawadoacre.wordpress.com>

Todas as entrevistas foram realizadas mediante a assinatura de Termo Livre e Esclarecido, e registradas com a autorização dos entrevistados, que também permitiram a divulgação de suas identidades, assim como de suas entrevistas. 
